Ana Maria Fraga

\title{
INÍCIO E MANUTENÇÃO DA INATIVAÇÃO DO CROMOSSOMO X EM CÉLULAS HUMANAS
}

São Paulo

2012 
Ana Maria Fraga

\section{Início e manutenção da inativação do cromossomo X em células humanas}

\section{Establishment and maintenance of X-chromosome inactivation in human cells}

Tese apresentada ao Instituto de Biociências da Universidade de São Paulo, para obtenção do Título de Doutor em Ciências, na Área de Biologia (Genética).

Orientadora: Profa. Dra. Lygia da Veiga Pereira Carramaschi

São Paulo

2012 
Fraga, Ana Maria

Início e manutenção da inativação do cromossomo $\mathrm{X}$ em células humanas.

$194 p$.

Tese (Doutorado) - Instituto de Biociências da Universidade de São Paulo. Departamento de Genética e Biologia Evolutiva.

Descritores: 1. Inativação do cromossomo X. 2. Célula-tronco embrionária humana. 3. Epigenética.

Universidade de São Paulo. Instituto de Biociências.

Departamento de Genética e Biologia Evolutiva.

Comissão Julgadora

Profa. Dra Lygia da Veiga Pereira Carramaschi

(orientadora) 
Este trabalho foi realizado com auxílio financeiro da FAPESP (Fundação de Amparo à Pesquisa do Estado de São Paulo), concedido à aluna Ana Maria Fraga (2008/00058-0). 
Gostaria de agradecer à Profa. Lygia Pereira, pela orientação, colaboração e estímulo durante todos esses anos de pesquisa.

Aos meus amigos de laboratório Ana Cláudia, Bruno, Cláudia, Cynthia, Fabiano, Fernanda, Fernando, Giovana, Gustavo, Tiago. Particularmente à Simone e à Naja, pela amizade, imensa ajuda nos experimentos e pelas discussões sobre ICX.

Aos meus amigos do Departamento de Genética, aos quais recorro sempre que necessário quase todos os dias... Em especial: Rafa, Lilian, Ana Carla, Teresa, Fátima, Mara, Lígia, Débora, Fernando, Juliana, Natale, Marianne e Marcos, pela ajuda, pelos cafés e almoços. Deisy e Helenice, não esqueço de vocês!

Agradeço aos professores Ângela Morgante, Regina Mingroni, Luciana Haddad, Sabine Eggers, Eduardo Gorab, Luís Netto e Luciana Vasques. À profa. Carla Rosemberg e sua equipe, pelo array-CGH; ao Fertility, em especial à Rita, Camila e Luciana, e à equipe do Centro de Reprodução Humana Prof. Franco Jr, pela colaboração. À Dra. Izabela Salomão, pela análise dos dados do REDOME, e à Dra. Virgínia Picanço, pela ajuda na produção dos lentivírus.

Sou muito grata especialmente à Érica, Joana e Raquel, minhas amigas de coração, que me ajudaram tantas vezes e fizeram minha rotina no laboratório mais feliz. Agradeço pelas discussões e sugestões, vocês também fazem parte disso tudo.

Aos meus familiares, tios e avós, que sempre torceram por mim.

E finalmente agradeço muito aos meus pais e irmãs, pelo carinho e incentivo. Obrigada por entenderem minha escolha e me apoiarem, pelo colo e pelo ombro, por me ajudarem a não perder o norte nos momentos difíceis. Sem vocês, eu não conseguiria. 


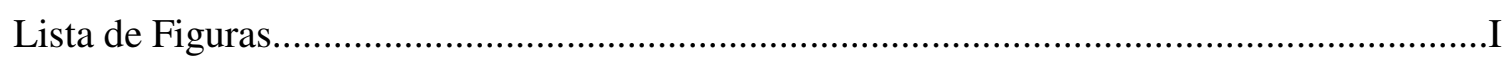

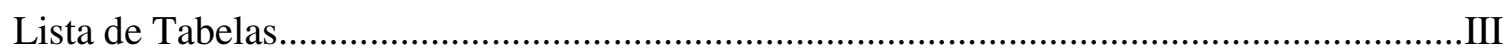

Lista de Abreviaturas............................................................................................

Capítulo I. Introdução ao estudo da inativação do X...........................................................

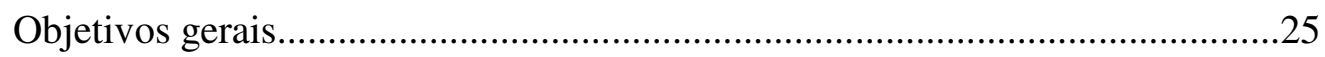

Capítulo II. Células-tronco embrionárias humanas como modelos de estudo do início da ICX

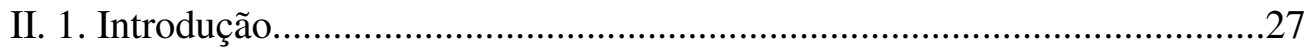

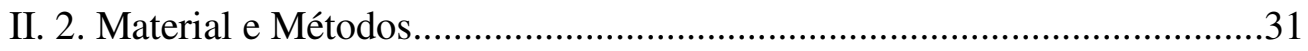

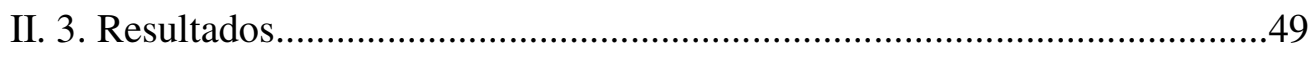

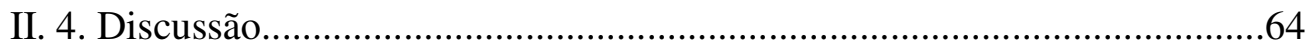

Capítulo III. Manutenção da ICX em células humanas: função de DNMT1, XIST e

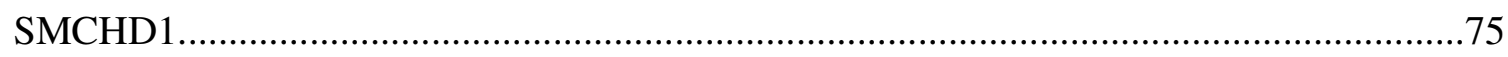

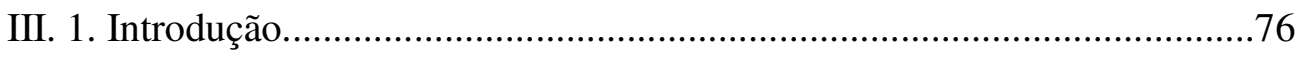

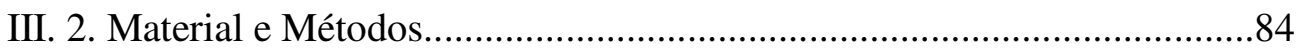

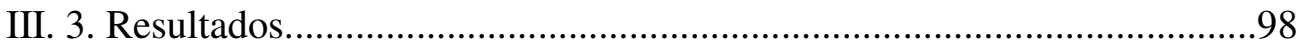

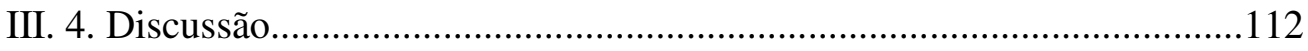

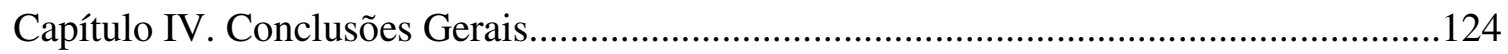

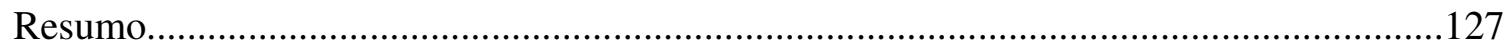

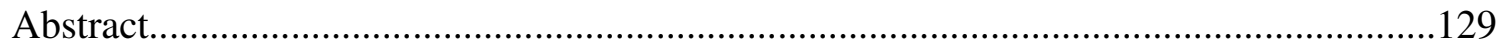

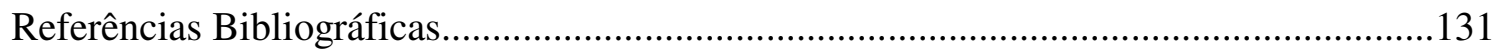

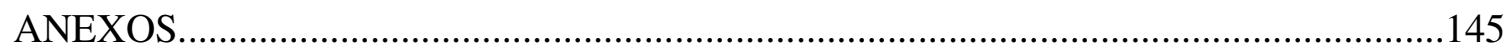




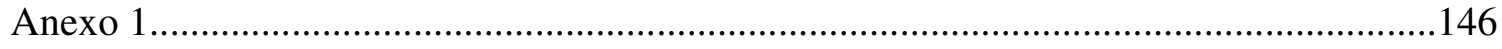

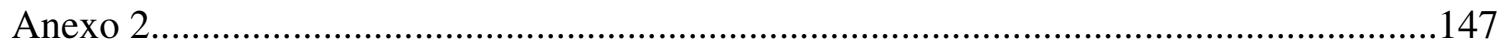

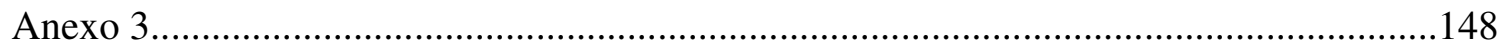

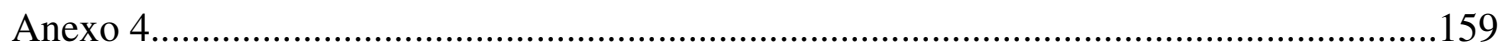

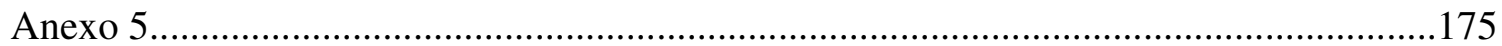




\section{LISTA DE FIGURAS}

Figura 1. Hipótese de um possível mecanismo evolutivo para compensação de dose em mamíferos

Figura 2. O RNA de Xist recobre o Xi.

Figura 3. Esquema representativo do centro de inativação do cromossomo $\mathrm{X}$ (Xic) murino.

Figura 4. Modelo de evolução da ICX em mamíferos. .23

Figura 5. Diagrama esquemático do gene Xist e de regiões vizinhas. .30

Figura 6. Células HUES não expressam XIST após diferenciação. .50

Figura 7. Estabelecimento de linhagens de hESC, utilizando feeder humano. .51

Figura 8. Estabelecimento da linhagem de hESC BR-1 .53

Figura 9. Aspectos morfológicos das células BR-1 53

Figura 10. Células BR-1 expressam marcadores de pluripotência...... .54

Figura 11. Estabilidade genômica da linhagem de hESC BR-1 após seis meses em cultura.

Figura 12. Diferenciação espontânea in vitro de células BR-1 produz células diferenciadas, derivadas dos três folhetos embrionários... 56

Figura 13. Células BR-1 formam teratomas quando injetadas em camundongos. .57

Figura 14. Expressão de XIST em linhagens de hESCs por RT-PCR em tempo real .60

Figura 15. Células BR-5 expressam marcador característico do Xi .61

Figura 16. Expressão alelo-específica de genes “imprintados” em células BR-5. .63

Figura 17. Quadro comparativo mostrando as principais características de células-tronco pluripotentes. .73 
Figura 18. Expressão de DNMT1 em fibroblastos GM135-Tel transduzidos com vetores para silenciamento deste gene.

Figura 19. Taxa de crescimento de fibroblastos transduzidos com vetores para silenciamento de DNMT1

Figura 20. Nível de metilação global em fibroblastos GM135-Tel transduzidos com vetores para produção de shRNAs contra $D N M T 1$ e tratados com VPA

Figura 21. Expressão de $M A O A$ e $M A O B$ em fibroblastos GM135-Tel após silenciamento de DNMT1, avaliada por RT-PCR. 104

Figura 22. Reativação do alelo submetido à ICX do gene $M A O A$ após silenciamento de DNMT1 e/ou tratamento com VPA. 105

Figura 23. Expressão de shRNAs contra o gene XIST em células GM135-Tel, monitoradas pela expressão de GFP (pGIPZ-XIST) e RFP (pTRIPZ-XIST) 107

Figura 24. Comparação dos valores de CTs médios para quatro genes normalizadores entre as amostras de fibroblastos transduzidos com vetores para produção de shRNAs contra XIST. 108

Figura 25. Expressão de XIST em fibroblastos GM135-Tel transduzidos com vetores para silenciamento deste gene 109

Figura 26. Taxa de crescimento de fibroblastos transduzidos com vetores para silenciamento de XIST. 110

Figura 27. Expressão de SMCHD1 em fibroblastos GM135-Tel transduzidos com vetores para silenciamento deste gene. 
Tabela 1. Composição dos meios de cultura utilizados 33

Tabela 2. Compatibilidade entre o perfil HLA de diferentes linhagens de hESCs com os dados do REDOME .58

Tabela 3. Ancestralidade genômica das células BR-1 e H1. .59

Tabela 4. Genotipagem de genes "imprintados" nas linhagens BR-1 e BR-5..... 62

Tabela 5. Expressão de genes "imprintados" em hESCs 63

Tabela 6. Genes avaliados e plasmídeos utilizados neste estudo. .87

Tabela 7. Expressão alelo-específica de genes ligados ao X em fibroblastos GM135-Tel após silenciamento de DNMT1 e tratamento com VPA 105

Tabela 8. Padrão de expressão de genes “imprintados” em células GM135-Tel após silenciamento de DNMT1 e/ou tratamento com VPA 106

Tabela 9. Expressão alelo-específica de genes ligados ao X em fibroblastos GM135-Tel após silenciamento de XIST... 110 
cDNA - DNA complementar

cSNP - polimorfismo de base única situado em região expressa

CTCF - fator ligante ao domínio CCCTC

DAPI - 4'6 - diamidina-2-fenilindole

DMSO - dimetilsulfóxido

DNA - ácido desoxirribonucleico

ESC - embryonic stem cell, célula-tronco embrionária

FH - fibroblastos humanos

hESC - human embryonic stem cell, célula-tronco embrionária humana

ICX - inativação do cromossomo X

ISCI - International Stem Cell Initiative

$\mathrm{Kb}$ - quilobase

$\mathrm{M}-$ molar

$\mathrm{Mb}$ - megabase

MCI - massa celular interna

MEF - fibroblastos embrionários murinos (mouse embryonic fibroblasts)

MESC - mouse embryonic stem cell, célula-tronco embrionária murina

$\mathrm{mX}$ - cromossomo X materno

naïve hIPSC - células humanas pluripotentes induzidas "imaturas"

ORF - open reading frame, quadro de leitura aberto

$\mathrm{pb}$ - pares de base

PBS - solução tampão fosfato-salina 
PCR - reação em cadeia da polimerase

Pou - (pituitary specific octamer, neural Unc-86) família de fatores de transcrição com homeodomínio

$\mathrm{pX}$ - cromossomo X paterno

RNA - ácido ribonucleico

rpm - rotações por minuto

RT-PCR - reação em cadeia da polimerase após transcrição reversa

SFB - soro fetal bovino

SNP - polimorfismo de base única (single nucleotide polymorphism)

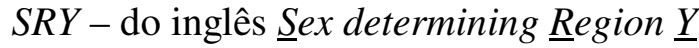

TA- temperatura ambiente

TAE - tampão Tris-Acetato-EDTA

TBE - tampão Trs-Borato-EDTA

TE - trofectoderme

TSIX/Tsix - do inglês $\underline{X}$-inactive specific transcript, antisense

U - unidade

$\mathrm{Xa}$ - cromossomo $\mathrm{X}$ ativo

$\mathrm{Xi}$ - cromossomo $\mathrm{X}$ inativo

XIC - X inactivation centre, centro de inativação do X

XIST/Xist - do inglês $\underline{X}$-inactive specific transcript 
Capítulo I

INTRODUÇÃO AO ESTUDO DA INATIVAÇÃO DO

Cromossomo X 


\section{Do corpúsculo de Barr à inativação do cromossomo X}

A primeira evidência sobre compensação de dose em fêmeas de mamíferos surgiu com a descrição de uma estrutura observada apenas no núcleo de neurônios de gatas, fenômeno observado por Barr e Bertram (1949). O "satélite nucleolar", como foi então denominado, é o que hoje se nomeia corpúsculo de Barr, e a simples presença dessa estrutura de localização peri-nucleolar em células de mamíferos poderia indicar o seu sexo.

A natureza dessa estrutura heterocromática no núcleo das células das gatas começou a ser definida em trabalhos posteriores. Cogitou-se que ela seria produto de parasitismo viral (Tjio \& Östergren, 1958) relacionado a carcinomas mamários. Entretanto, Ohno e Hauschka (1960), trabalhando com camundongos, afirmaram que o corpúsculo de Barr era na verdade um cromossomo $X$, presente não só em tumores como também em células normais das fêmeas, sendo esta característica a base citológica para o dimorfismo sexual em mamíferos.

\section{$\underline{\text { A Hipótese de Lyon }}$}

Em 1961, Mary Lyon descreveu em um artigo sucinto suas considerações sobre a causa de um dos cromossomos $\mathrm{X}$ ser heterocromático nas células femininas, o que ela classificou como inativação do cromossomo X (ICX). A pesquisadora partiu de algumas evidências, como o fenótipo em mosaico de genes ligados à cor da pelagem (localizados no cromossomo $\mathrm{X}$ ) exclusivo de fêmeas, e o fato de que camundongos com cariótipo 39,X são fêmeas normais e férteis. Fundamentada nessas observações de genética de camundongos, a hipótese de Lyon propõe que o cromossomo X heterocromático está inativo; o silenciamento de um dos dois cromossomos $\mathrm{X}$ das fêmeas permite aos sexos 
neutralizar o desequilíbrio resultante de doses não-equivalente de produtos gênicos ligados ao $\mathrm{X}$ e ao $\mathrm{Y}$.

No ano seguinte (1962), Mary Lyon publicou um extenso artigo, no qual ela ampliou suas observações sobre o fenômeno da ICX a outros mamíferos. Suas pertinentes considerações forneceram a primeira fundamentação para uma hipótese de compensação de dose entre os sexos, e servem de embasamento para boa parte do que se procura entender sobre o mecanismo. Partindo de evidências fenotípicas, clínicas (em humanos) e citogenéticas, ela sugeriu que:

- o corpúsculo de Barr é um cromossomo X geneticamente inativado em todas as células somáticas das fêmeas de mamíferos;

- a ICX ocorre precocemente durante o desenvolvimento embrionário;

- a ICX ocorre de maneira aleatória, podendo ser inativado tanto o X de origem paterna $(\mathrm{pX})$ quanto o de origem materna $(\mathrm{mX})$;

- uma vez definido o $\mathrm{X}$ inativo (Xi), este permanece inativado ao longo das divisões celulares (a inativação é clonal);

- o mecanismo de ICX garante que somente um cromossomo X permaneça ativo por núcleo diplóide (2n), mesmo em células com polissomia do X (regra n-1).

$\mathrm{Na}$ época, a hipótese de Lyon encontrou alguma resistência na comunidade científica (Vines, 1997), pois a ideia de que um organismo mantivesse um cromossomo inteiro funcionalmente inerte jamais havia sido levantada. Hoje a hipótese da ICX proposta por Lyon é aceita como uma teoria. 
Compensação de dose em mamíferos - a hipótese de Ohno

A hipótese de Lyon trouxe desdobramentos importantes. Um deles se refere ao balanço entre produto gênico dos cromossomos sexuais versus autossômicos. A princípio, poder-se-ia pensar que, tanto nas fêmeas quanto nos machos, a relação de produtos gênicos entre o cromossomo $\mathrm{X}$ e os autossomos seria 0,5 ; ou seja, por possuírem somente um dos Xs ativo, os cromossomos sexuais estariam em desequilíbrio em relação aos autossomos.

Ohno (1969) propôs um mecanismo evolutivo para explicar a compensação de dose em mamíferos. Segundo este modelo, os cromossomos sexuais evoluíram a partir de um par de autossomos. A aquisição do gene determinante sexual masculino SRY (sex-determining region $Y$ ) num dos homólogos deste par (denominado proto-Y) desencadeou ao longo da evolução a perda de segmentos do proto-Y, diminuindo assim a chance de recombinação entre proto-Y e proto-X. A consequência desta degradação do Y (ou erosão) seria um desequilíbrio de dose entre autossomos e cromossomos sexuais nos machos, e entre os cromossomos sexuais em machos e fêmeas (Figura 1). Ohno afirmou então que, além da inativação de um cromossomo X nas fêmeas, deveria haver uma superexpressão do único $\mathrm{X}$ nos machos e do $\mathrm{X}$ ativo nas fêmeas para compensar em relação aos autossomos, evitando assim uma haploinsuficiência funcional dos genes localizados no X. 


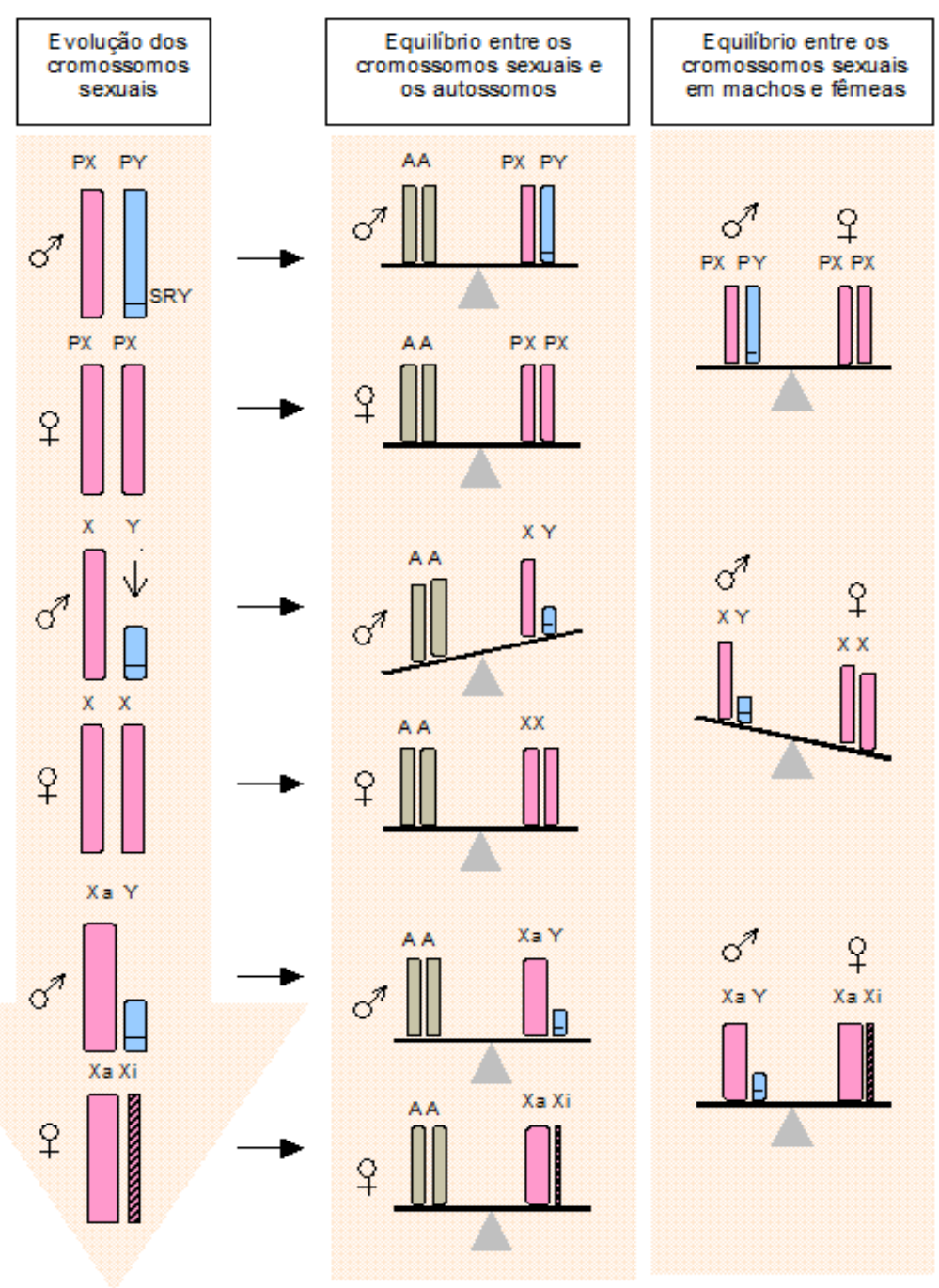

Figura 1: Hipótese de um possível mecanismo evolutivo para compensação de dose em mamíferos. Os cromossomos sexuais teriam surgido a partir de um par de autossomos (PX e PY: proto-X e proto $\mathrm{Y}$, respectivamente). A aquisição de genes determinantes sexuais masculinos como o $S R Y$ no PY desencadeou um processo de erosão deste cromossomo, com a finalidade de impedir recombinação entre $\mathrm{X}$ e $\mathrm{Y}$, o que levou a um desequilíbrio gênico entre os produtos dos cromossomos sexuais e autossomos nos machos, e entre os produtos gênicos do $\mathrm{X}$ entre machos e fêmeas. A superexpressão do X ativo em machos e fêmeas e a ICX em fêmeas restabeleceriam o equilíbrio gênico entre os sexos (modificado de Payer \& Lee, 2008).

A hipótese de Ohno pôde ser testada recentemente com ferramentas biomoleculares poderosas. Nguyen e Disteche (2006) compararam, em seis espécies de mamíferos, a expressão de genes no $\mathrm{X}$ com a dos autossomos, utilizando a técnica de microarray. Os resultados mostraram que genes no cromossomo $\mathrm{X}$ eram 
superexpressos, de modo que a relação X:AA era aproximadamente 1, de acordo com o que previa Ohno. No entanto, Xiong e colaboradores (2010), utilizando dados robustos de sequenciamento de RNA (RNA-seq), mostraram que a relação X:AA era próxima de 0,5, o que refutaria a hipótese de compensação de dose entre sexuais e autossomos. Em artigo recente, Castagné e colaboradores (2011) concluíram que, dependendo do filtro aplicado à análise dos dados do microarray, resultados discrepantes poderiam ser obtidos: como padrão, genes de baixa expressão seriam eliminados, pois não chegam ao limite de detecção dos microarrays, o que resultaria numa superestimativa de expressão de genes no X. A questão ainda é alvo de investigação e debate; contudo, vale ressaltar que, independentemente dos resultados alcançados com as diferentes técnicas, um mecanismo molecular responsável pela possível superexpressão do $\mathrm{X}$ ainda não foi proposto.

\section{$\underline{\text { Padrões de ICX }}$}

O fenótipo em mosaico de genes ligados ao X levou a interpretação de que a ICX fosse um evento aleatório, ou seja, que os cromossomos Xs provenientes do pai e da mãe tivessem igual probabilidade de serem inativados. Por ser um fenômeno aleatório, o esperado seria que cerca de $50 \%$ das células de uma fêmea possuíssem o pX inativo, enquanto que em outros $50 \%$ das células possuíssem o mX inativo. No entanto, em algumas situações, a aleatoriedade da ICX foi contraposta, e desvios de inativação favorecendo um dos cromossomos $\mathrm{X}$ foram descritos.

\section{A ICX em tecidos extraembrionários}

Em 1975, Takagi e Sasaki observaram que tecidos de origem extraembrionária murinos apresentavam desvio completo de ICX, favorecendo a inativação do 
cromossomo $\mathrm{X}$ proveniente do pai. Trabalhos subsequentes confirmaram que tecidos extraembrionários não só de camundongos como também bovinos exibiam uma forma de ICX dependente da origem parental, denominada "imprintada" (Wake, Takagi e Sasaki, 1976; West et al., 1977; Xue et al., 2002), em que o cromossomo inativado era sempre o de origem paterna. A forma "imprintada" de ICX foi identificada antes mesmo de o fenômeno ser descrito em genes autossômicos imprintados, em meados da década de 80.

Alguns trabalhos procuraram investigar o padrão da ICX em tecidos de origem extraembrionária humanos. Os dados da literatura são bem controversos: enquanto alguns autores relatam que o padrão da ICX em placenta é "imprintado" (como em camundongos), outros o definem como aleatório. Em 2010, nosso grupo publicou um trabalho onde foi realizada uma extensa investigação em placenta humana a termo, e concluímos que a ICX neste tecido ocorre de forma aleatória, diferente do que ocorre em camundongos (Moreira de Mello et al., 2010). A conclusão do trabalho levanta uma pergunta, relacionada à evolução do padrão de ICX “imprintado" em tecidos extraembrionários de mamíferos; estudar este padrão em placenta de primatas nãohumanos seria fundamental para entender a evolução no padrão de ICX em mamíferos placentários.

\section{A ICX em marsupiais}

Marsupiais (Metatheria) e mamíferos placentários (Eutheria) divergiram há aproximadamente 148 milhões de anos, e mesmo naqueles mamíferos mais basais o fenômeno da ICX já foi descrito. Sharman (1971) observou em cangurus que a inativação acontece preferencialmente no cromossomo X paterno, e este padrão além de 
ocorrer nos tecidos de origem extraembrionária é também observado nos tecidos somáticos das fêmeas.

No item "Modelo para a evolução da ICX" são discutidas as diferenças moleculares e fenotípicas no processo da ICX entre marsupiais e placentários, o que permite algumas especulações sobre como o processo evoluiu em mamíferos.

\section{Silenciamento do cromossomo $X$ durante a gametogênese masculina}

Um tipo de silenciamento que envolve o cromossomo $\mathrm{X}$ ocorre também na linhagem germinativa masculina (Lifschytz \& Lindsley, 1972), por meio da inativação meiótica do cromossomo sexual (meiotic sex chromosome inactivation - MSCI). Durante a formação dos gametas masculinos, regiões não pareadas dos cromossomos $\mathrm{X}$ e Y são transcricionalmente silenciadas, formando uma estrutura distinta heterocromática denominada corpúsculo XY (XY body); acredita-se que o silenciamento destas regiões tenha como objetivo impedir a recombinação.

Ao contrário do que se previa, boa parte das regiões heterocromáticas do corpúsculo XY permanece silenciada após o término da meiose na forma de cromatina pós-meiótica (post-meiotic sex chromatin - Greaves et al., 2006). No entanto, após a fertilização, as regiões de heterocromatina serão remodeladas.

\section{A ICX durante o desenvolvimento embrionário}

Quando ocorre a ativação do genoma do zigoto, em camundongos no estágio de 2-4 células, elementos repetitivos presentes no $\mathrm{pX}$ (que sofreu silenciamento durante a gametogênese masculina) continuam silenciados (Okamoto et al., 2004). Genes codificadores presentes no $\mathrm{pX}$ encontram-se inicialmente ativos mas progressivamente são inativados durante o período pré-implantação, um processo que pode ser facilitado 
pelo compartimento silenciado já estabelecido nas regiões repetitivas (Namekawa et al., 2010). Assim, blastocistos murinos jovens (dia embrionário 3.5 - E3.5) apresentam o pX inativo em todas as suas células. Existe a hipótese de que essa forma "imprintada" paterna de ICX, que ocorre nas fases iniciais do desenvolvimento de embriões femininos, possa ser resquício da MSCI, que daria origem a um cromossomo pX préinativado (Huynh \& Lee, 2003).

Após a fase de blastocisto jovem, os destinos dos tecidos embrionários e extraembrionários divergem. Composto da endoderme primitiva e da trofectoderme, tecidos extraembrionários mantêm o pX inativado, enquanto que o epiblasto, que dá origem ao embrião propriamente dito, reativa o $\mathrm{pX}$ e passa por uma nova fase de estabelecimento de ICX que independe da origem parental, ou seja, neste segundo momento a inativação se dá de maneira aleatória (Mak et al., 2004). Portanto, a forma aleatória de ICX, reconhecida desde os relatos de Mary Lyon (1961), é resultado da manutenção do sinal de inativação que ocorreu nas células originadas da diferenciação do epiblasto.

Dados sobre o que ocorre durante o desenvolvimento humano são escassos, devido principalmente às implicações éticas advindas do uso de embriões humanos em pesquisa. Mesmo em países mais permissivos existem dificuldades em se obter embriões humanos de boa qualidade, uma vez que o material seria descartado em clínicas de fertilização.

Dois trabalhos recentes tiveram como objetivo investigar a ICX durante a embriogênese humana. No entanto, eles apresentaram dados conflitantes. Van den Berg e colaboradores (2009) observaram indícios da ICX em embriões humanos do estágio de 6-8 células até blastocistos, mas não foi possível saber se o padrão de ICX era "imprintado" ou aleatório, pois a doação dos embriões era anônima. Por outro lado, 
Okamoto e colaboradores (2011) afirmaram não existir evidência de ICX em embriões humanos pré-implantação, mesmo em blastocistos. A questão permanece aberta e ainda resta abordá-la em embriões mais jovens, investigação que pode ser impossibilitada em decorrência legislação vigente em cada país.

\section{$O$ Centro de Inativação do Cromossomo X}

Desvios de inativação também ocorrem em tecidos somáticos, em camundongos e humanos portadores de translocações X:autossomos. Essas translocações têm uma propriedade importante: a disseminação da inativação para loci autossômicos (Russell \& Montgomery, 1965; Cattanach, 1974). Além disso, rearranjos dessa natureza com frequência provocam desvios de inativação, favorecendo um dos cromossomos $\mathrm{X}$. Como afirmou Rastan (1983), dois eventos poderiam ser causadores desses desvios: ou a ICX ocorreria de maneira aleatória, e por seleção as células com maior equilíbrio gênico seriam mantidas, ou a ICX não seria aleatória a princípio, devido a perturbações no processo em si, por possível rearranjo envolvendo um centro controlador da inativação.

Em alguns casos, a primeira hipótese pôde ser corroborada, como em algumas populações celulares sanguíneas de mulheres portadoras de mutação no gene ligado ao X, HPRT1 (hipoxantina fosforibosil-transferase), cuja disfunção leva à Síndrome de Lesch-Nyhan (Nyhan et al., 1970). No entanto, parecia existir um centro de inativação no cromossomo $\mathrm{X}$, pois somente um dos produtos da translocação era inativado. Nestas situações, o produto menor quase nunca era inativado, o que sugeria que o produto maior da translocação continha uma porção responsável por desencadear a inativação daquele cromossomo (Russell \& Montgomery, 1965; Russell \& Cacheiro, 1978). Modelos para explicar o desvio de inativação observado em diversos camundongos 
portadores de translocação X:autossomos foram propostos, baseados na existência de um centro de inativação do X (Xic - X inactivation centre - Russell, 1963; Lyon, 1971; Mattei et al., 1981). O Xic foi descrito como a região mínima necessária responsável pela inativação, o qual deveria estar fisicamente associado a um cromossomo X para que ele fosse inativado (ação in cis).

O mapeamento dos pontos de quebra das translocações X:autossomo permitiu a localização do Xic na porção distal da banda XD em camundongos (Rastan, 1983), e na banda Xq13 em humanos (XIC - Brown et al., 1991b); o detalhamento molecular do Xic revelou que há sintenia completa dessa região entre camundongos e humanos (Brown et al., 1991b). Diversos trabalhos demonstraram que inserções do fragmento do XIC em cromossomos diferentes podem também provocar o silenciamento neste contexto ectópico (Lee et al., 1996; Migeon et al., 1999; Heard et al., 1999), o que comprova sua importância para a ocorrência da ICX.

\section{$\underline{\text { Mecanismos moleculares da ICX }}$}

\section{Células-tronco embrionárias}

Não seria possível compreender o processo da ICX sem a existência de modelos experimentais apropriados. A hipótese para explicar a ocorrência da ICX já havia sido proposta. Restava saber quando e como isso se dava. Embriões em desenvolvimento seriam os candidatos mais adequados para tentar responder a essas perguntas. Assim, a obtenção de células-tronco embrionárias (embryonic stem cells - ESCs) foi uma conquista fundamental para que se pudesse avançar nas pesquisas sobre ICX.

Isoladas por Evans e Kaufman em 1981, as ESCs murinas (mouse embryonic stem cells - mESCs) são provenientes da massa celular interna (MCI) de blastocistos, e representam um embrião em desenvolvimento. Esta população celular pluripotente 
mantém suas características quando cultivadas sob condições apropriadas. Extraordinariamente, as mESCs femininas apresentam in vitro os dois cromossomos $\mathrm{X}$ ativos, refletindo o status de ICX observado nas células do epiblasto; com a indução da diferenciação, elas realizam a ICX in vitro, e é neste momento que podem ser identificados os fatores determinantes do processo.

Os itens seguintes contêm diversas considerações importantes sobre o estabelecimento da ICX obtidas em estudos realizados em ESC. Contudo, uma revisão mais detalhada sobre estas células pode ser consultada no Capítulo II.

\section{Início ou estabelecimento da ICX}

A análise do Xic/XIC permitiu a identificação de vários fatores importantes para a ICX. O locus Xce (do inglês X chromosome-controlling element) de camundongos foi mapeado dentro do Xic, e aos seus alelos foram atribuídas propriedades de conferir diferentes chances do cromossomo $\mathrm{X}$ portador ser submetido à inativação (Cattanach $e t$ al., 1969; Johnston \& Cattanach, 1981).

Um gene situado dentro do XIC com propriedades bem particulares foi descrito em 1991 (Brown et al., 1991a). Ele é expresso exclusivamente pelo cromossomo X inativo (Xi), e por esta razão ele foi denominado XIST (X-Inactive Specific Transcript). Tanto o gene humano quanto o homólogo murino foram identificados no mesmo ano (Brown et al., 1991a; Borsani et al., 1991, Brockdorff et al., 1991). XIST/Xist é um transcrito de RNA longo (17 kb e $15 \mathrm{~kb}$, respectivamente), expresso somente por células femininas, de localização específica nuclear. Os genes humano e murino compartilham regiões de considerável homologia em sua sequência, possuem diversas repetições organizadas em tandem e não possuem ORFs (Brown et al., 1992; Brockdorff et al., 1992). 
Análises do padrão de expressão de Xist/XIST demonstraram que o transcrito se acumula no cromossomo $\mathrm{Xi}$ in cis (Clemson et al., 1996), formando uma espécie de "nuvem" que o recobre (Figura 2). Em camundongos, este padrão se mantém mesmo durante a metáfase (Figura 2). Vários estudos mostraram que fêmeas heterozigotas para mutação em Xist apresentam desvio de inativação que favorece o alelo selvagem, ou seja, inativam o cromossomo $\mathrm{X}$ que possui o alelo selvagem de Xist; o gene é imprescindível também para o estabelecimento da forma "imprintada" de ICX em mamíferos placentários (Mararhens et al., 1997; Penny et al., 1996).

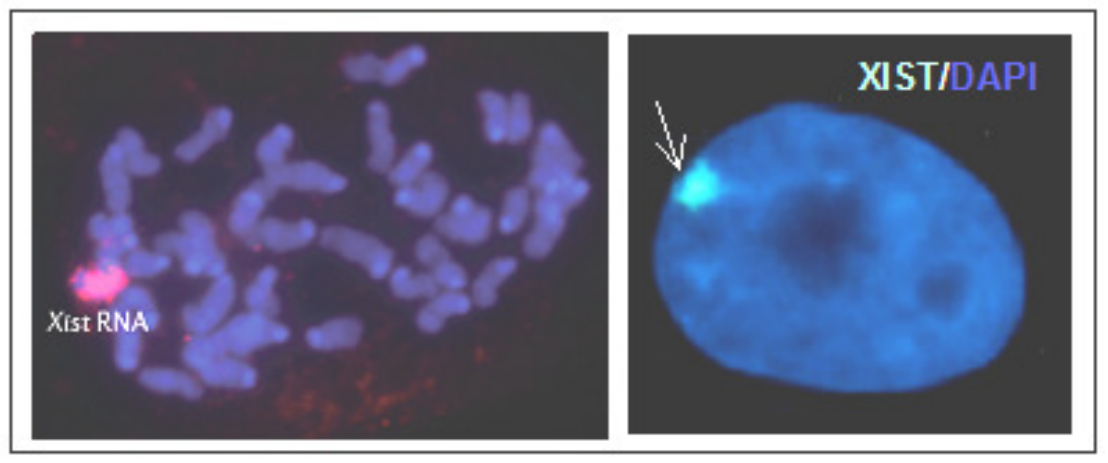

Figura 2: O RNA de Xist recobre o Xi. À esquerda, núcleo metafásico de fibroblasto murino, mostrando associação do RNA de Xist (em vermelho) durante esta fase do ciclo celular (Lee, 2009). À direita, núcleo interfásico de fibroblasto feminino humano; a seta indica sinal de RNA de XIST em verde (Hall et al., 2002).

Um transcrito regulador de XIST foi identificado em mESCs, denominado Tsix (Lee et al., 1999a). Tsix se localiza a 3’ do gene Xist, e seu locus já havia sido anteriormente associado à ICX (Courtier et al., 1995; Debrand et al., 1999). Tsix é transcrito em orientação contrária a do gene Xist, originando uma sequência antissentido que se sobrepõe completamente a de Xist (daí seu nome, Tsix).

Foi observado que os dois alelos de Tsix são expressos em mESCs indiferenciadas femininas. Durante a diferenciação in vitro, ocorre repressão de $T$ six e a indução de Xist in cis no Xi (revisto por Boumil \& Lee, 2001). Lee \& Lu (1999) 
demonstraram que fêmeas de camundongo portadoras de mutação em Tsix exibiam desvio de inativação, favorecendo o alelo mutado; os autores concluíram que Tsix regula Xist in cis e desta maneira determina a escolha de qual $\mathrm{X}$ será inativado, sem comprometer o silenciamento.

Em humanos, um transcrito antissentido ao XIST de aproximadamente $27 \mathrm{~kb}$ foi identificado (Migeon et al., 2001). No entanto, TSIX não se sobrepõe completamente à sequência de XIST, como ocorre em camundongos. Além disso, enquanto Tsix é expresso pelo $\mathrm{X}$ ativo (Xa) em camundongos, TSIX é expresso pelo Xi em humanos (Migeon, 2002), sugerindo que Tsix e TSIX tenham funções diferentes. Até o momento, não se sabe se XIST é regulado por TSIX em humanos. Migeon (2002) sugere que TSIX é um remanescente de Tsix cujas funções se perderam. Assim, em humanos, um regulador direto de XIST não foi identificado.

\section{Xist e heterocromatinização do $X$}

O simples acúmulo dos transcritos de Xist no futuro Xi, apesar de sugestivo, não explica como essa associação promove a heterocromatinização. Existe uma estreita relação entre o início do silenciamento e o acúmulo do RNA do Xist ao longo do cromossomo X. Entretanto, o modo de ação de Xist na ICX começou a ser esclarecido somente em 2008, com o trabalho de Zhao e colaboradores.

Estudos prévios mostraram que havia diferença entre a composição das histonas no Xa e no Xi. Já se sabia que o Xi era enriquecido de histonas $\mathrm{H} 4$ desacetiladas (Jeppesen \& Turner, 1993), de histonas H3 metiladas nos resíduos de lisina (K) (Heard et al., 2001) e da variante de histona macroH2A1.2 (Costanzi \& Pehrson, 1998). Essas 
modificações de maneira geral alteram a expressão gênica, e a presença de algumas delas caracteriza regiões de intensa ou de baixa transcrição.

Em especial, o Xi é rico em histonas $\mathrm{H} 3$ com trimetilação na lisina 27 (H3K27me3), uma marca característica de cromatina reprimida; a aquisição dessa marca é o primeiro evento observado logo após o RNA de Xist recobrir o Xi (revisto por Nora \& Heard, 2010). Proteínas remodeladoras de cromatina do complexo repressivo das Polycombs tipo 2 - PRC2 -, responsáveis pela deposição de H3K27me3, também estão altamente concentradas no Xi (Plath et al., 2003; Silva et al., 2003). Zhao e colaboradores (2008) verificaram que o RNA de Xist se liga diretamente a PRC2, e esta interação faz com que o complexo se concentre no Xic e depois se espalhe por todo o cromossomo Xi, disseminando o sinal de inativação. Assim, é a presença dos transcritos de Xist que provoca as modificações epigenéticas responsáveis pelo silenciamento do Xi, possibilitando a passagem de um estado eucromático para um heterocromático.

Não se sabe ainda como outras proteínas remodeladoras de cromatina são recrutadas para o futuro $\mathrm{Xi}$, nem quando ocorre o seu enriquecimento com as demais modificações de histonas. É certo que a aquisição da variante macroH2A.1.2 e a metilação do DNA das regiões promotoras de genes ligados ao Xi são eventos tardios durante a processo de heterocromatinização do X (Morey \& Avner, 2011; Nora \& Heard, 2010).

Vale lembrar que diversos transcritos longos de RNAs não codificadores (long non-coding RNAs - lncRNA) também já foram identificados dentro do XIC e acredita-se que, além do Xist, um intrincado balanço entre expressão e regulação recíproca destes RNAs e de algumas proteínas determinam o início da ICX (Figura 3). 


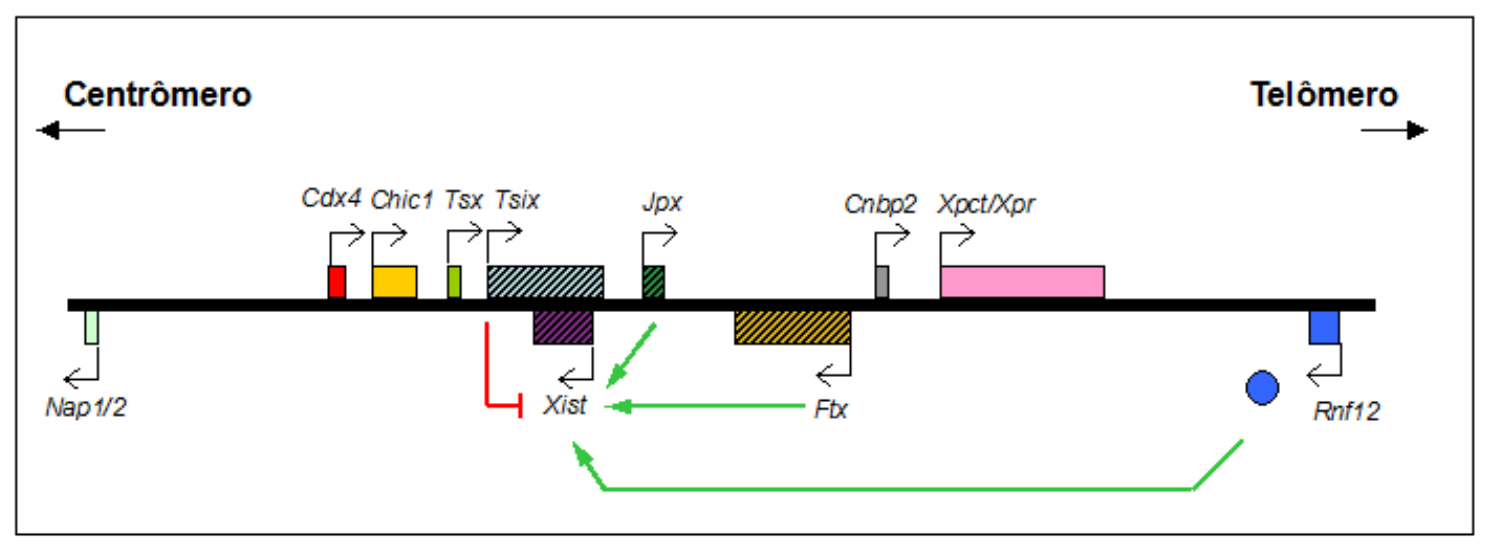

Figura 3: Esquema representativo do centro de inativação do cromossomo X (Xic) murino. A região possui vários RNAs não-codificadores, simbolizados pelos retângulos com linhas diagonais. Setas em verde indicam ativadores de Xist, e seta bloqueada em vermelho indica repressor de Xist. Rnf12 é uma E3 ubiquitina-ligase que ativa Xist in trans. Modificado de Yang e colaboradores, 2011.

\section{Contagem e escolha}

Um dos aspectos mais intrigantes sobre a ICX é a constatação que somente um cromossomo X permanece ativo por núcleo diplóide, conhecido como regra n-1. Por esta razão, acredita-se que haja um fenômeno de contagem, em que a razão X:autossomos é "calculada" e a ICX é desencadeada em todos os cromossomos X com exceção de um deles por núcleo diplóide. Como predito pela regra, células X0 e XY não apresentam corpúsculo de Barr, XX e XXY exibem um e fêmeas XXX possuem dois (Lyon, 1972; Kay et al., 1994).

Embora esteja claro que a presença do transcrito de Xist no futuro Xi desencadeie as mudanças epigenéticas posteriores, não se sabe como os transcritos de Xist permanecem associados a somente um dos cromossomos X, e não se difunde para outras regiões nucleares e/ou outros cromossomos. Algumas hipóteses já foram levantadas, mas elas ainda carecem de mais evidências.

Uma das hipóteses é baseada na existência de um curto período durante a diferenciação celular em que os dois cromossomos $\mathrm{X}$ se pareiam (XIC pairing). $\mathrm{O}$ fenômeno foi observado por diferentes grupos (Bacher et al., 2006; Xu et al., 2006), e 
acredita-se que no momento da associação entre os dois cromosomos $\mathrm{X}$ ocorra uma quebra de simetria que faz com que a expressão de Tsix, antes bialélica, torne-se monoalélica. A expressão monoalélica de Tsix cria um estado permissivo para o aumento de expressão e acúmulo do RNA de Xist em somente um dos cromossomos X.

Zhang e colaboradores (2007) observaram que somente após a ocorrência do pareamento dos $\mathrm{Xs}$, o futuro $\mathrm{Xi}$ assume um compartimento nuclear diferente, com localização preferencial perinuclear. Autossomos que possuem um XIC ectópico também passam a residir próximos ao nucléolo.

Ainda não são conhecidos os fatores que promovem o pareamento dos Xs durante a diferenciação, e nem quais fenômenos moleculares se estabelecem durante o tempo em que os dois Xs permanecem pareados; estudos poderão esclarecer se esse evento é de fato responsável pela escolha de qual X permanecerá ativo.

\section{Disseminação do sinal de inativação}

Diversos trabalhos verificaram que o RNA de Xist recobre o cromossomo Xi integralmente. Mas não se sabe ao certo que afinidades existem entre a molécula de RNA de XIST/Xist e a cromatina do futuro Xi para haja associação entre elas.

Comparado aos autossomos, o cromossomo X possui o dobro de elementos do tipo LINE-1 (do inglês Long INterspersed Elements), sequências repetitivas longas de DNA, as quais contém região promotora e ORFs, dispersas por todo o genoma, e que se acredita terem surgido por retrotransposição (Bailey et al., 2000). Lyon (1998) propôs que as sequências LINE-1 enriquecidas no cromossomo $\mathrm{X}$ serviriam como sítios de ancoragem do transcrito de Xist e de outros fatores que contribuem para o silenciamento, ajudando o sinal de inativação a se espalhar por todo o cromossomo 
(revisto por Wutz, 2007). Com relação ao RNA de Xist, Wutz e colaboradores (2002) afirmam que a presença de muitas regiões redundantes deste RNA confere-lhe a capacidade de se associar ao futuro Xi.

\section{Genes que escapam à ICX}

$\mathrm{O}$ processo de inativação ocorre in cis a partir do XIC, e o sinal segue pelo cromossomo X nas duas direções (Brown et al., 1991a). Os genes transcricionalmente ativos são silenciados, com exceção de algumas regiões que escapam da inativação (revisto por Vasques et al., 2002). Em humanos, até 15\% dos genes ligados ao cromossomo X escapam da inativação, e outros $10 \%$ exibem inativação variável, sendo bialelicamente expressos em somente um grupo de mulheres ou em determinados tecidos (Carrel \& Willard, 2005). Em camundongos essa porcentagem é bem menor, cerca de 3\%, o que pode explicar a ausência de um fenótipo anormal associado a animais 39,X, em contraste com mulheres 45,X, que raramente sobrevivem até o nascimento e, quando viáveis, possuem Síndrome de Turner (revisto por Disteche et al., 2002).

Muitos dos genes que escapam à inativação encontram-se agrupados no braço curto do $\mathrm{X}$, residindo dentro do estrato mais jovem, adquirido mais recentemente na evolução dos mamíferos (Carrel et al., 1999; Ross et al., 2005); outros se localizam na região pseudoautossômica e possuem homólogos funcionais no cromossomo Y, que podem sofrer recombinação durante a meiose (revisto por Disteche, 1995).

Segmentos genômicos no cromossomo X com menor quantidade de sequências LINE-1 possuem mais genes que escapam à inativação (Bailey et al., 2000), um indicativo da importância destas sequências no silenciamento gênico. Além disso, em 
translocações, a propagação da ICX para loci autossômicos parece depender da concentração desses elementos no autossomo translocado (revisto por Lyon, 1998). O mecanismo de escape envolve outros fatores, como a presença de elementos isoladores complexos de cromatina e proteínas que agem como barreiras aos sinais de reguladores transcricionais positivos (enhancers) ou negativos (silencers) -, e/ou elementos in cis localizados nas proximidades de uma região de escape que podem promovê-lo (revisto por Lee, 2011).

\section{Manutenção da ICX}

Uma vez estabelecida, a marca de inativação do X mantém-se ao longo de toda a vida; em cada célula feminina, o mesmo Xi é mantido de maneira clonal: todas as células-filhas herdam a escolha do $\mathrm{Xi}$, e acredita-se que haja um mecanismo responsável pela manutenção desta informação. Não são muitos os trabalhos, no entanto, que conseguem esclarecer definitivamente as particularidades da manutenção da ICX; acredita-se que a falha está em se encontrar um modelo celular apropriado para abordar essas questões.

Mesmo assim, podemos inferir quais vias seriam importantes para o processo, baseados nas características do Xi. Além de manter continuamente a expressão e reter a "nuvem" de XIST/Xist, o compartimento nuclear que o Xi ocupa encontra-se silenciado transcricionalmente; logo, não há atividade de RNA polimerase II. Além disso, o Xi está enriquecido de algumas modificações pós-traducionais em histonas (H3K27me3, H3K9me2, H4K20me1) e da variante de histona do tipo macroH2A1.2 (revisto por Nora \& Heard, 2010). Finalmente, as citosinas de dinucleotídeos CpG das regiões promotoras gênicas encontram-se metiladas no Xi (revisto por Goto \& Monk, 1998; Brockdorff, 2002; Hall \& Lawrence, 2003). Esses aspectos indicam que proteínas 
responsáveis pela acetilação/metilação de histonas e metilação do DNA desempenham uma função importante durante a manutenção do estado inativo do X.

Com relação à metilação do DNA, o papel da enzima DNMT1, que tem afinidade por DNA hemi-metilado (revisto por Bestor, 2000), tem sido amplamente explorado. Células-tronco embrionárias murinas deficientes para o gene Dnmt1 exibem desmetilação global de DNA (Li et al., 1992; 1993), e após diferenciação, possuem um padrão aberrante da expressão de Xist, demonstrando que a Dnmt1 é fundamental na regulação da expressão alelo-específica de Xist. Quando deficientes em Dnmt1, as mESCs masculinas expressam Xist após a diferenciação, provocando inativação do único X nos machos e dos dois cromossomos X nas fêmeas (Panning \& Jaenisch, 1996). Desta maneira, em camundongos os resultados indicam que Dnmt1 regula a expressão de Xist e, portanto, é fundamental para a ICX (Beard et al., 1995; Panning \& Jaenisch, 1996).

Csankovszki e colaboradores (2001) afirmaram que, em camundongos, é necessário que Xist permaneça expresso continuamente em células somáticas adultas, uma vez que a deleção do gene provocou a reexpressão de alguns loci ligados ao X. Acima de tudo, os autores afirmam que existe um sinergismo entre a contínua expressão de Xist, a atuação de Dnmt1 e de complexos de histona desacetilases (HDCAs) para manter o Xi em camundongos. Boumil e Lee (2001) também relataram que as perdas de Xist e de histonas do tipo macroH2A1.2 levavam à reativação do cromossomo Xi.

Alguns trabalhos já procuraram abordar a manutenção de ICX em humanos; até o momento, porém, poucos são os paralelos possíveis. Com relação à expressão de XIST humano, Brown e Willard (1994) afirmam que o gene não é necessário para manter o estado inativo do X: a ausência do XIC não provocou reativação de genes submetidos à ICX, ao contrário do que foi observado em camundongos. É importante dizer que os 
autores usaram como modelo células híbridas, obtidas da fusão entre células humanas e murinas, que definitivamente não reproduzem condições encontradas naturalmente e, portanto são modelos epigeneticamente duvidosos. Ademais, a razão para que XIST continue sendo expresso em células somáticas permanece sem resposta.

O papel da DNMT1 na ICX humana ainda é alvo de debates. Células HCT116 (derivadas de carcinoma humano) nocautes para DNMTl exibem pouca diminuição nos níveis de metilação global do DNA, da ordem de 20\% (Rhee et al. 2000; 2002). Já o duplo-nocaute $D N M T 1 / D N M T 3 B$, esta última uma metiltransferase de novo, apresentou redução de $97 \%$ nos níveis de metilação global do DNA, o que sugere uma redundância funcional entre estas duas proteínas humanos. Nosso laboratório procurou investigar a expressão de XIST nessas células com acentuada hipometilação e, diferentemente do que ocorre em camundongos, níveis tão baixos de metilação não foram suficientes para causar expressão de XIST (Vasques et al., 2005). Porém, como as células HCT116 são XY, não foi possível avaliar o efeito de perda de metilação de DNA nos genes submetidos à ICX.

Blewitt e colaboradores (2008) demonstraram que em camundongos uma proteína da família das coesinas e condensinas era importante para a manutenção da ICX. Fêmeas de camundongos nocautes para SmcHDl (structural-maintenance-ofchromosomes hinge domain) morriam antes do nascimento, e apesar de exibirem padrão de expressão de Xist normal, apresentavam sinais de reativação do $\mathrm{Xi}$, com hipometilação de ilhas $\mathrm{CpG}$ e reexpressão de genes submetidos à ICX. Tal descrição abriu novas oportunidades de investigação da manutenção da ICX em mamíferos, pois em C. elegans as proteínas SMCs desempenham importante função no processo de compensação de dose, contribuindo para a redução da expressão dos dois Xs nos hermafroditas. 


\section{Modelo para a evolução da ICX}

Como descrito, a ICX é observada em mamíferos placentários e também em marsupiais. Apesar de ser conservado há milhões de anos, o processo em si apresenta diferenças significativas entre esses grupos.

A primeira grande diferença entre a ICX de marsupiais e de placentários é que nos primeiros o padrão nas fêmeas é "imprintado", enquanto que nos últimos ele é aleatório em relação aos tecidos embrionários. Assim como o Xi de fêmeas de camundongos e humanos, o $\mathrm{Xi}$ dos marsupiais é replicado tardiamente na fase $\mathrm{S}$ do ciclo celular (Graves, 1967; Sharman, 1971). Entretanto, em marsupiais, o corpúsculo de Barr é observado somente em determinados tecidos de algumas espécies (VandeBerg et al., 1987); marcas epigenéticas características do Xi em mamíferos placentários não são evidentes em marsupiais, como por exemplo a metilação de DNA em loci específicos (Loebel \& Johnston, 1996). Por estas razões, a ICX em marsupiais é comumente descrita como incompleta, instável e tecido-específica (Cooper et al., 1993), e em termos moleculares, uma discrepância fundamental é a ausência de XIST no genoma de marsupiais (Hore et al., 2007).

O padrão "imprintado" de ICX em marsupiais também é observado em tecidos extraembrionários murinos, sugerindo que ele representa uma forma ancestral do mecanismo de ICX. Baseados no perfil de modificações em histonas presentes no Xi em marsupiais e placentários, Chaumeil e colaboradores (2011) propõem um modelo de evolução do processo de ICX (Figura 4). Segundo este modelo, o acúmulo de marcas de heterocromatina constitutiva no X, assim como a H3K27me3 e a H3K9me2 caracteriza o modo "imprintado" de ICX (com o silenciamento do pX) num ancestral do grupo Theria. A aquisição do gene XIST no ancestral dos placentários foi crucial para estabilizar o recrutamento dessas variantes de histonas, surgindo um novo modo de 
inativação com maquinaria XIST-dependente. Assim, o Xi dos marsupiais poderia representar um estado intermediário do processo de ICX, situando-se entre o recrutamento de marcas epigenéticas de heterocromatina constitutiva, e a forma mais estável e complexa de heterocromatina dependente de XIST dos mamíferos placentários.

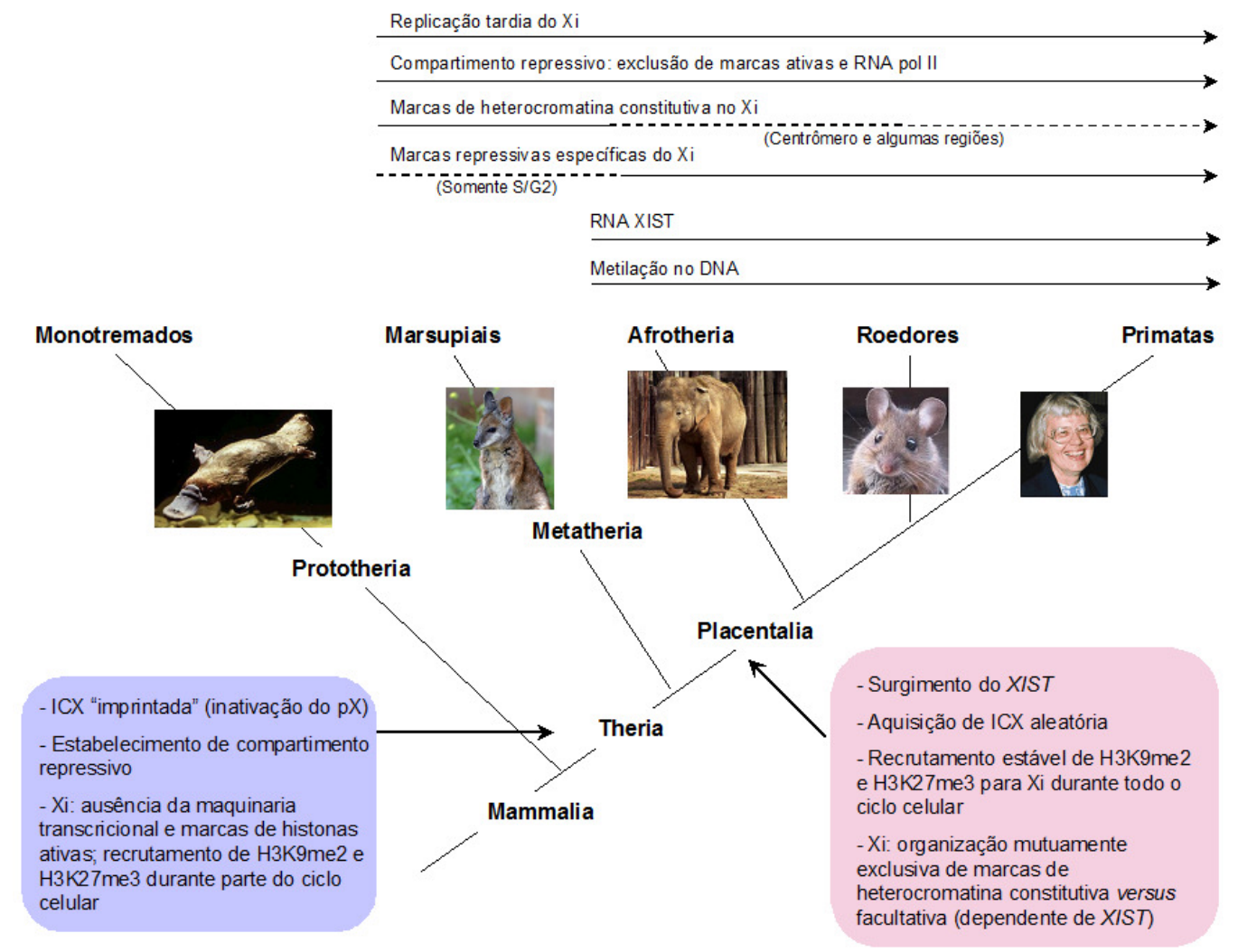

Figura 4: Modelo de evolução da ICX em mamíferos. Os quadros azul e rosa indicam características epigenéticas compartilhadas pelo grupo especificado. Setas contínuas indicam componentes estáveis da ICX encontrados nos clados; setas interrompidas indicam modificações repressivas instáveis. Modificado de Chaumeil e colaboradores, 2011.

\section{$\underline{\text { O Estudo da ICX em células humanas }}$}

Nossos conhecimentos sobre as diversas etapas do processo de ICX são resultados de investigação realizada com células murinas. Entretanto, já são conhecidas 
algumas diferenças entre a ICX de humanos e camundongos (revisto por Vasques et al., 2002).

Por exemplo, com relação ao início do fenômeno, o padrão de expressão de XIST não parece ser idêntico entre as duas espécies: enquanto o transcrito de XIST humano dissocia-se do Xi durante a prófase, o RNA de Xist recobre o Xi durante a metáfase (Smith et al., 2004). Além disso, a associação do RNA de Xist no Xi parece necessitar de fatores espécie-específicos, visto que XIST não recobre o cromossomo $\mathrm{X}$ humano quando presente num background de camundongo em híbridos somáticos humanocamundongo (Tinker \& Brown, 1998). Não se sabe ainda qual é o papel do gene TSIX humano em relação à regulação de XIST.

Até o momento, os trabalhos que investigaram a manutenção da ICX em humanos foram baseados na utilização de modelos celulares artificiais, os híbridos somáticos humano/roedor, ou células transformadas. Ao se estudar as funções de XIST e DNMT1 na manutenção da ICX humana, encontramos resultados e conclusões muito discrepantes, o que reforça a necessidade de abordagem das mesmas questões em células epigeneticamente mais próximas do estado natural.

Diante destas afirmações, foi objetivo deste trabalho investigar o início e a manutenção da ICX em células humanas. Para tanto, foram utilizadas como modelos de estudo do estabelecimento da ICX linhagens de células-tronco embrionárias humanas (human embryonic stem cells - hESCs), derivadas em nosso e em outros laboratórios. A função de XIST, DNMT1 e SMCHD1 na manutenção da ICX foi avaliada em fibroblastos humanos imortalizados. 


\section{OBJETIVOS GERAIS}

Este trabalho teve como objetivos gerais a caracterização de linhagens de células hESC como modelos para estudo do início da ICX, e a investigação da função de três fatores, DNMT1, XIST e SMCHD1, na manutenção da ICX humana. Especificamente foram nossas intenções:

- Estabelecer em nosso laboratório novas linhagens de hESC e caracterizá-las;

- Verificar o status da ICX em linhagens de hESCs, indiferenciadas e diferenciadas, com ênfase na análises da expressão do gene XIST;

- Avaliar o papel de XIST, SMCHD1 e DNMT1 na manutenção da ICX em humanos, por RNAi em fibroblastos imortalizados com a subunidade catalítica da telomerase humana (hTERT).

Nota: Para facilitar a exposição dos experimentos e seus resultados, este trabalho foi dividido em capítulos. Na sequência, o capítulo II dedica-se ao estudo do início da ICX; o capítulo III, à manutenção da ICX. Ao final da tese, um capítulo de conclusões gerais reúne as principais considerações das duas investigações. 


\section{Capítulo II}

CÉlulas-Tronco EMbrionárias Humanas

COMO MODELOS DE ESTUDO DO INÍCIO DA ICX 
A derivação das primeiras linhagens de células-tronco embrionárias murinas (mouse embryonic stem cells - mESCs), descrita por Evans e Kaufman (1981) e Martin (1981), representou um avanço excepcional em vários campos das ciências biológicas e moleculares. Quando reintroduzidas em um embrião pré-implantação, as mESCs possuem a capacidade de retomar o desenvolvimento normal do organismo, contribuindo para a formação de tecidos derivados dos três folhetos embrionários originando quimeras. Em conjunto com a tecnologia do DNA recombinante, as mESCs são amplamente utilizadas para a geração de camundongos geneticamente modificados, produzindo modelos animais para o estudo de várias doenças genéticas, nos quais podese estudar a função gênica in vivo. Para a ciência básica, as mESCs refletem in vitro o que ocorre durante o desenvolvimento embrionário de camundongos, elucidando o engenhoso processo que determina a pluripotencialidade e, a partir dela, o surgimento de células diferenciadas e de alta complexidade funcional.

A maioria das linhagens de mESCs são provenientes do cultivo das células da massa celular interna (MCI), retiradas de blastocistos. Essa população celular é capaz de originar todas as células do embrião (derivadas da mesoderme, ectoderme e endoderme), com exceção dos tecidos extraembrionários. Por essa razão elas são denominadas pluripotentes, e possuem perfil de expressão gênica característico de seu estado indiferenciado e autorrenovável. As linhagens de mESCs conservam in vitro a expressão dos fatores envolvidos com a pluripotência que são observados in vivo (revisto por Deuve \& Avner, 2011). Os mais importantes são os fatores de transcrição Oct3/4, Nanog, e Sox2, que formam uma rede compacta de interação proteína-proteína, e podem se associar a outros complexos proteicos de modo a manter a pluripotência. 
Variações na estabilidade e na concentração desses fatores promovem um ajuste fino responsável pelos eventos que decidem o destino celular durante o desenvolvimento (Orkin \& Hochedlinger, 2011).

Oct3/4 (ou simplesmente Oct-4 - fator de transcrição com homeodomínio da família $P o u$ ) é codificado pelo gene Pou5f1, e sua alta expressão reflete o estado da pluripotência celular. Seus níveis estão intimamente relacionados à diferenciação de maneira dose-dependente, induzindo ao comprometimento mesodérmico, endodérmico ou trofoblástico (Niwa et al., 2000). Nanog (fator de transcrição da classe homeobox NK-2) e Sox2 (fator de transcrição relacionado a SRY, HMG-box) parecem não estar envolvidos diretamente com a pluripotência in vivo; no entanto, Sox-2 parece regular a expressão de Oct-4 (Masui et al., 2007), e Nanog estabiliza o estado de pluripotência ao regular a autorrenovação independente de citocinas das ESCs (Chambers et al., 2003).

Apesar de terem como alvo sequências de DNA diferentes, os três fatores estabelecem associação com as mesmas proteínas, e participam da regulação das mesmas vias. Uma forte evidência da interconexão entre eles foi obtida por dois trabalhos diferentes, que analisaram as regiões regulatórias de genes alvo de fatores de transcrição relacionados à pluripotência (Chen et al., 2008; Kim et al., 2008). Genes que são expressos em ESCs e "desligados" quando ocorre diferenciação tendem a possuir regiões promotoras que podem ser alvo de sete ou mais fatores de transcrição, o que reforça a participação de fatores diferentes para manter a pluripotência; em contraste, genes com sítios de ligação para quatro ou menos fatores tendem a estar silenciados em ESCs. 
Associação entre pluripotência e o estabelecimento da ICX

A reativação do $\mathrm{pX}$ inativo nas células da $\mathrm{MCI}$ em blastocistos murinos indicava que, de alguma maneira, o perfil de expressão único e específico destas células poderia também ser responsável pela reativação do cromossomo $\mathrm{X}$. De fato, Navarro e colaboradores (2008) observaram que Sox 2 , Nanog e Oct3/4 têm como alvo o intron 1 do gene Xist, e que, ao se ligarem a este sítio, bloqueiam sua expressão. Além disso, Rex1, Klf4, c-Myc (todos eles fatores também envolvidos com a pluripotência) associam-se à região regulatória de Tsix, ativando sua expressão (Donohoe et al., 2009).

Outras evidências sustentam o envolvimento dos fatores de pluripotência em eventos como o pareamento dos Xs durante a diferenciação (Donohoe et al., 2009), e na regulação negativa da expressão de Rnf12, gene localizado no XIC cuja proteína ativa a ICX de maneira dose-dependente (Navarro et al., 2011). Além disso, inibidores da expressão de Nanog e Klf4 durante a diferenciação celular, como Satb1 (Savarese et al., 2009) agem como "fatores de competência" da ICX, possivelmente por atuarem como remodeladores de cromatina ou via ativação de Xist (Agrelo et al., 2009).

Assim, diversos trabalhos afirmam que fatores importantes para a pluripotência impedem o estabelecimento da ICX em ESCs de camundongos, e em contrapartida, a diminuição da expressão desses fatores com a diferenciação celular desencadeia o início da ICX. Em suma, os resultados obtidos apontam para uma função direta dos fatores de pluripotência e seus reguladores na ICX, por atuação em diferentes passos do processo (Figura 5). 


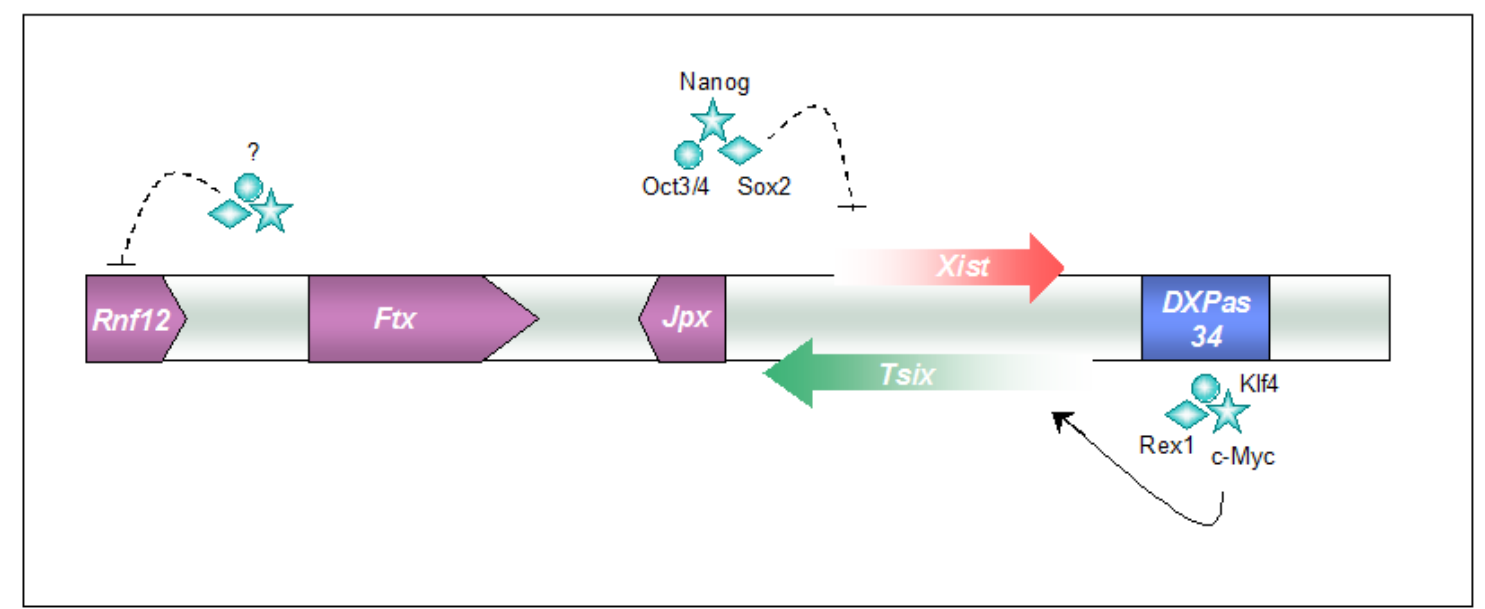

Figura 5: Diagrama esquemático do gene Xist e de regiões vizinhas. Ativadores (roxo) e repressor (azul) de Xist são regulados por fatores de transcrição envolvidos na manutenção da pluripotência. Jpx e Ftx originam RNAs não-codificadores que regulam positivamente Xist. Oct3/4, Sox2 e Nanog inibem a expressão de Xist. DXPas34 atua como enhancer de Tsix, e é sítio de ligação de Rex1. A região 5' de Tsix também é alvo de c-Myc e Klf4, levando ao aumento de expressão de Tsix. Ainda não se sabe como Rnf12 se enquadra nesta rede de regulação. Modificado de Deuve \& Avner, 2011.

\section{Estabelecimento de linhagens de células-tronco embrionárias humanas}

Thomson e colaboradores derivaram em 1998 as primeiras linhagens de célulastronco embrionárias humanas (human embryonic stem cells - hESCs), criando grandes expectativas quanto ao seu uso terapêutico em medicina regenerativa.

As condições de derivação das primeiras linhagens de hESCs foram essencialmente as mesmas usadas na derivação das mESCs, mas desde 1998 houve diversas mudanças no protocolo de estabelecimento das linhagens, visando a sua aplicação clínica; no entanto, apesar de obedecerem aos critérios recomendados para denominá-las como tal (expressão de marcadores de pluripotência, diferenciação nos três folhetos embrionários in vitro e in vivo), as hESCs possuem algumas características que as diferem das mESCs. As colônias de hESCs são morfologicamente muito diferentes das mESCs; além disso, as hESCs são mantidas indiferenciadas e pluripotentes com o uso de bFGF (basic-Fibroblast Growing Factor), ao contrário das mESCs, cuja pluripotência é mantida com LIF (Leukemia Inhibitor Factor). 
Em teoria, o estudo do início da ICX e outros aspectos da embriogênese humana se faria possível em hESCs. Assim, o objetivo deste trabalho foi investigar o potencial das linhagens de hESCs como modelos de estudo do início da ICX em nossa espécie.

\section{2. MATERIAL E MÉTODOS}

\section{$\underline{\text { Práticas gerais de cultivo }}$}

II. 2.1. Descongelamento das células

Alíquotas criopreservadas das células foram descongeladas por dois minutos em banho-maria a $37{ }^{\circ} \mathrm{C}$. Ao descongelado adicionaram-se $4 \mathrm{~mL}$ de meio de cultura variável, conforme o tipo celular (DMEM-F12 ou Knockout DMEM para hESCs, DMEM para fibroblastos). As células foram centrifugadas a temperatura ambiente por 5 minutos a $1000 \mathrm{rpm}$.

O meio foi sugado e ao precipitado foi acrescentado meio de cultura apropriado dependente do tipo celular. As células foram mantidas a $37^{\circ} \mathrm{C}$ em incubadora com $5 \%$ $\mathrm{CO}_{2}$.

\section{2.2. Subcultivo celular}

As células foram expandidas de modos diferentes; porém, em todos os casos, o meio de cultura foi sugado, as células foram brevemente lavadas com 1X PBS (Invitrogen) e seguia-se a dissociação das células nas placas de cultura. Assim, fibroblastos humanos e murinos foram soltos das placas de cultivo com o tratamento com $0,25 \%$ tripsina-EDTA (Invitrogen) por 5 minutos na incubadora. A reação foi interrompida com a adição de meio de cultura próprio contendo soro fetal bovino (SFB 
- Cultilab) e, em seguida, as células foram centrifugadas por 5 minutos a $1000 \mathrm{rpm}$; o sobrenadante foi retirado e ao precipitado foi adicionado meio fresco, em volume conveniente para expansão das células.

No caso das colônias de hESCs, as células foram desagregadas manualmente. Após a retirada do meio de cultura, as células receberam meio fresco e, com o auxílio de agulhas de insulina $\left(27,5 \mathrm{G}^{1 / 2}\right)$ sob estereomicroscópio, as colônias foram repartidas em porções menores, originando agregados celulares. Esses grumos foram então transferidos para novas placas previamente semeadas com feeder humano ou murino, ou mesmo somente com matrigel (no caso de células cultivadas com meio mTeSR1).

\section{2.3. Congelamento das células}

Para o congelamento das células, protocolos diferentes foram utilizados. No caso dos fibroblastos humanos ou murinos, o congelamento seguiu o protocolo de passagem enzimática com tripsina, e ao final o precipitado de células isoladas recebeu meio de congelamento composto de 10\% DMSO, 20\% SFB (Cultilab) e DMEM com alta concentração de glicose (DMEM-high - Invitrogen). As alíquotas em criotubos foram mantidas por 48 horas em freezer $-80{ }^{\circ} \mathrm{C}$ e depois foram estocadas indefinidamente em nitrogênio líquido.

Como nas passagens, as hESCs foram isoladas para congelamento mecanicamente; em seguida, os grumos foram centrifugados a $1000 \mathrm{rpm}$ por 5 minutos, o sobrenadante foi retirado e aos grumos foram adicionados $500 \mu \mathrm{L}$ de meio de cultura próprio. A esse conteúdo, outros $500 \mu \mathrm{L}$ de meio de congelamento [20\% DMSO, 20\% SFB (Hyclone) em meio de cultura] foram gotejados vagarosamente. Os criotubos eram arranjados no container Nalgene ${ }^{\circledR}$ Mr. Frosty (Sigma-Aldrich), guardados a $-80{ }^{\circ} \mathrm{C}$ e depois passados para tanques de nitrogênio líquido. 
Manutenção das células

Como este trabalho lidou com o cultivo de linhagens celulares diferentes, para facilitar a leitura optamos por confeccionar uma tabela contendo o protocolo de cada meio de cultura utilizado (Tabela 1). O texto fará referência ao nome dado a cada formulação especificada nesta tabela.

Tabela 1: Composição dos meios de cultura utilizados.

\begin{tabular}{|c|l|l|}
\hline Meios de Cultura & \multicolumn{1}{|c|}{ Protocolo } & \multicolumn{1}{|c|}{ Suporte $^{\star}$} \\
\hline feeder & $15 \%$ SFB (Cultilab) & Não se aplica \\
& $2 \mathrm{mM}$ Glutamax-I & \\
& $50 \mathrm{u} / \mathrm{ml}$ penicilina e $50 \mu \mathrm{g} / \mathrm{ml}$ estreptomicina & \\
& DMEM high glucose & \\
\hline
\end{tabular}

Manutenção das hESCs

\begin{tabular}{|c|c|c|}
\hline hESC "A" & $\begin{array}{l}10 \% \text { Knockout Serum Replacement } \\
10 \% \text { Plasmanate (Bayer) } \\
2 \text { mM Glutamax-I } \\
1 \text { X Aminoácidos não-essenciais } \\
50 \mathrm{u} / \mathrm{ml} \text { penicilina e } 50 \mu \mathrm{g} / \mathrm{ml} \text { estreptomicina } \\
0,055 \mathrm{mM} \text { b-mercaptoetanol } \\
10 \mathrm{ng} / \mathrm{mL} \text { bFGF (RD Systems) } \\
\text { Knockout DMEM }\end{array}$ & MEFs inativados \\
\hline hESC "B" & $\begin{array}{l}20 \% \text { Knockout Serum Replacement } \\
50 \mathrm{u} / \mathrm{ml} \text { penicilina e } 50 \mu \mathrm{g} / \mathrm{ml} \text { estreptomicina } \\
1 \mathrm{X} \text { Aminoácidos não-essenciais } \\
1 \mathrm{mM} \text { Glutamax-I } \\
0,055 \mathrm{mM} \beta \text {-mercaptoetanol } \\
5 \mathrm{ug} / \mathrm{mL} \text { gentamicina } \\
10 \mathrm{ng} / \mathrm{mL} \text { insulina } \\
100 \mathrm{ng} / \mathrm{mL} \text { ácido ascórbico } \\
20 \mathrm{ng} / \mathrm{mL} \text { bFGF (RD Systems) } \\
\text { DMEM-F12 }\end{array}$ & FH inativados \\
\hline hESC "C" & 100\% mTeSR1 (Stem Cell Technologies) & matrigel $^{\#}$ \\
\hline
\end{tabular}

\section{Derivação de hESCs}

\begin{tabular}{|c|l|c|}
\hline I & composição idêntica ao meio hESC "B" & FH inativados \\
\hline II & $10 \%$ Knockout Serum Replacement & MEFs inativados \\
(usado 1:1 com meio & $2,5 \%$ SFB (Hyclone) & \\
condicionado & $2 \mathrm{mM}$ Glutamax-I & \\
por hESCs) & $1 \mathrm{X}$ aminoácidos não-essenciais & \\
& $0,055 \mathrm{mM} \beta$-mercaptoetanol & \\
& $50 \mathrm{u} / \mathrm{ml}$ penicilina e $50 \mu \mathrm{g} / \mathrm{ml}$ estreptomicina & \\
& $5 \mathrm{ng} / \mathrm{mL}$ bFGF (RD Systems) & \\
& Knockout DMEM & \\
\hline III & $100 \%$ mTeSR1 (Stem Cell Technologies) & matrigel $^{\#}$ \\
\hline
\end{tabular}

*descrito no item II. 2.4; ${ }^{\#}$ matrigel hESC certified (BD Biosciences)

FH: fibroblastos humanos; MEFs: fibroblastos embrionários murinos.

Todos os componentes não especificados foram adquiridos da empresa Invitrogen 


\section{2.4. Preparação de camada de feeder}

Dois tipos de camadas alimentadoras (feeder) foram utilizados, um proveniente de fibroblastos embrionários murinos (mouse embryonic fibroblasts ou MEFs) e outro de fibroblastos de prepúcio humano (FH), da linhagem HS27 (ATCC).

Os MEFs foram obtidos a partir de embriões murinos de 13,5 dias pós-coito (dpc). Assim, fêmeas de camundongos prenhes foram sacrificadas, e os embriões foram retirados com o auxílio de tesouras estéreis. Os embriões foram macerados sem as vísceras e a cabeça, com tesouras. Os tecidos macerados foram incubados com tripsina0,25\% EDTA por 10 minutos a $37^{\circ} \mathrm{C}$. Após esse tempo, houve nova maceração e pipetagem vigorosa, e depois outra incubação com tripsina por 10 minutos a $37^{\circ} \mathrm{C}$. As células isoladas resultantes foram semeadas em garrafas de cultivo de área conveniente, dependendo do número de embriões obtidos (dois embriões para cada garrafa T75).

MEFs ou FH foram cultivados em meio de cultura para feeder (ver Tabela 1), e para serem usados como tal foram inativados mitoticamente por irradiação gama (50 Gy) ou por tratamento com $10 \mu \mathrm{g} / \mathrm{mL}$ de mitomicina-C (Merck). No dia anterior ao plaqueamento das hESCs, aproximadamente 500 mil fibroblastos irradiados ou tratados com mitomicina-C (humanos ou murinos) eram semeados em placas de $60 \mathrm{~mm}$, previamente tratadas com $0,1 \%$ de gelatina (Invitrogen).

\section{2.5. Linhagens internacionais de hESC}

Algumas linhagens de hESC em passagem iniciais (HUES1, HUES9, HUES14, HUES15) derivadas por Cowan e colaboradores (2004) foram adquiridas pelo nosso laboratório. As células foram mantidas inicialmente em meio de cultura hESCs "A" (Tabela 1) plaqueadas sobre uma camada de MEFs irradiados. 
Para experimentos como imunocitoquímica e hibridação in situ fluorescente (FISH) de RNA, onde a presença da camada de MEFs poderia dificultar a interpretação dos resultados, as células foram cultivadas sobre matrigel hESC certified (BD Biosciences) e meio de cultura definido mTeSR1 (Stem Cell Technologies). A cultura foi mantida em estufa $5 \% \mathrm{CO}_{2}$ e a $37^{\circ} \mathrm{C}$.

O tempo de passagem variou com a linhagem, entre 6-10 dias. As colônias foram passadas mecanicamente com o auxílio de uma agulha de insulina e transferidas para uma nova camada de MEFs ou para matrigel.

\section{Derivação de novas linhagens de hESCs}

II. 2.6. Obtenção dos embriões e cultura do blastocisto/massa celular interna (MCI)

Novas linhagens de hESCs foram obtidas a partir de embriões produzidos in vitro por clínicas de reprodução assistida, ou seja, para fins reprodutivos, congelados há mais de três anos, de acordo com as exigências da Lei de Biossegurança 11.105 de 25 de março de 2005. Os pais biológicos consentiram com a doação dos embriões. O projeto foi aprovado pelo Comitê de Ética do Instituto de Biociências (IB-USP), protocolo $n^{\circ} 044 / 2006$.

O descongelamento e cultivo de embriões até atingirem estágio de blastocisto foram realizados pelas clinicas de fertilização in vitro colaboradoras: Fertility - Centro de Reprodução Assistida (São Paulo) e Centro de Reprodução Humana Prof. Franco Jr. (Ribeirão Preto). A zona pelúcida foi removida por disparos de laser (Turetsky et al., 2008), por cortes feitos com agulhas de insulina ou com lâminas acopladas ao micromanipulador. Quando foi possível identificar a massa celular interna (MCI) do blastocisto, esta foi isolada mecanicamente e semeada em placas de cultura que 
continham fibroblastos irradiados ou matrigel (BD Biosciences). Quando não foi possível identificar a MCI, os embriões foram plaqueados inteiros, sem a zona pelúcida.

Foram utilizados três meios de cultura diferentes para derivação das linhagens; a composição de cada um deles e se eles foram utilizados em conjunto com feeder estão detalhados na Tabela 1. Independente do meio de cultura empregado, após 48 horas do isolamento e plaqueamento da MCI ou embrião, metade do volume de meio de cultura foi trocada e posteriormente, durante o período de derivação, metade do volume de meio de cultura foi trocada a cada dois dias. Particularmente durante a derivação usando o meio "II" (Tabela 1), nos dias sem troca de meio, as células foram suplementadas com insulina, ácido ascórbico e FGF. Assim que se observaram colônias maiores, o meio foi trocado diariamente.

Para cada embrião ou MCI isolada, o tempo da primeira passagem variou entre 7 e 16 dias após o isolamento; os grumos de células foram transferidos mecanicamente para nova camada de MEFs ou FHs inativados ou para placa tratada com matrigel. Da mesma maneira, as passagens seguintes foram realizadas a cada 6-8 dias, mecanicamente. Eventualmente, as colônias foram fragmentadas em grumos, que foram congelados como descrito no item II. 2.3.

\section{Caracterização das linhagens}

\section{2.7. Imunocitoquímica}

Para avaliar o estado pluripotente das células, foram realizados ensaios de imunocitoquímica utilizando anticorpos específicos. Para tal, foi adquirido o ES Cells Marker Sample Kit (Chemicon), com os antígenos SSEA-4, TRA-1-60 e TRA-1-81, e OCT-4 (Santa Cruz Biotechnology, Inc). 
As células foram cultivadas em placas de 24 poços, contendo lamínulas de vidro, ou então em câmaras de LabTeks (Nunc), tratadas previamente com matrigel. Após crescimento das colônias, o meio de cultura foi retirado e as células foram lavadas 2 vezes com PBS (Invitrogen), fixadas com 4\% paraformaldeído (PFA) por 10 minutos e depois lavadas com PBS. As células foram permeabilizadas com solução de PBS $0,1 \%$ Triton X-100 (Sigma) por 5 minutos, incubadas com solução de bloqueio (PBS $+1 \%$ SFB-Cultilab $+0,1 \%$ Triton $\mathrm{X}-100$ ) por uma hora, e em seguida com os anticorpos (TRA-1-60, TRA-1-81, SSEA-4) diluídos em solução de bloqueio na proporção de 1:50 ou, no caso do OCT-4, na proporção de 1:100, durante 16 horas a $4{ }^{\circ} \mathrm{C}$. No dia seguinte, as soluções com anticorpo foram retiradas e as células foram lavadas três vezes com PBS/0,1\% Triton X-100 por 5 cinco minutos cada. Em seguida, as células foram incubadas com anticorpo secundário antimouse IgG conjugado com Cy3 (GE Healthcare) diluído em solução de bloqueio (1:200) por uma hora a temperatura ambiente. As lâminas foram lavadas 4 vezes com PBS por 5 minutos a temperatura ambiente, e montadas em meio Vectashield contendo DAPI (Vector Laboratories, Inc.).

As colônias foram observadas em microscópio de fluorescência Axiophot 2 (Carl Zeiss, Oberkochen, Alemanha), do Laboratório de Genética Humana II (Departamento de Genética e Biologia Evolutiva - IB-USP). Para documentação, as imagens foram capturadas por câmera CCD e processadas pelo software ISIS (MetaSystem, Altlussheim, Alemanha).

\section{2.8. Cariótipo das células}

O cariótipo foi analisado através de bandeamento $\mathrm{G}$, segundo protocolos estabelecidos (Gosden et al., 1992) e com o auxílio do grupo da Profa. Dra. Ângela M. Vianna Morgante (IB-USP). 
As células foram tratadas com $4 \times 10^{-5} \mathrm{M}$ de colchicina por 45 minutos e mantidas na incubadora, lavadas com PBS e incubadas com $0,25 \%$ tripsina-EDTA por 5 minutos a $37{ }^{\circ} \mathrm{C}$. A reação foi interrompida com a adição de meio de cultura, e após centrifugação de 5 minutos a $1000 \mathrm{rpm}$, as células foram ressuspendidas em solução hipotônica ( $\mathrm{KCl}$ 0,075M). Após 15 minutos de incubação a $37{ }^{\circ} \mathrm{C}$, algumas gotas de solução fixadora (3 etanol: 1 ácido acético) foram acrescentadas às células. Nova centrifugação foi realizada (1000 rpm por 7 minutos), o sobrenadante foi aspirado, às células foram adicionados gentilmente $5 \mathrm{ml}$ de solução fixadora, e seguiu-se outra centrifugação a $1000 \mathrm{rpm}$ por 7 minutos. O sobrenadante foi sugado, as células foram ressuspendidas em solução fixadora e guardadas a $-20{ }^{\circ} \mathrm{C}$ até exame do seu cariótipo. Cerca de 20 metáfases celulares foram analisadas.

Para análise mais detalhada do cariótipo, foi realizado um array genômico (CGH-Array), pelo grupo da Profa. Dra. Carla Rosemberg (IB-USP). Com resolução média de $70 \mathrm{~Kb}$, o array utilizado contém 44 mil oligonucleotídeos (Human Genome Microarray CGH 44A, Agilent Technologies). O DNA das células foi obtido com o kit de purificação Flexigene DNA (Qiagen), conforme orientações do fabricante, e marcado posteriormente com Cy3-dCTP. Uma amostra de DNA marcada com Cy5-dCTP, proveniente de uma linhagem de fibroblastos humanos GM135-Tel (GM00135 - Coriell Institute) com atividade de telomerase restituída GM135-Tel (46,XX), foi usada como controle. Os passos de purificação, hibridação e lavagem foram realizados de acordo com a recomendação dos fabricantes. As imagens do array foram processadas com Agilent Feature Estraction v9.5.1 e analisadas pelo software CGH Analiytics 3.4.40 (Agilent Technologies) com o algoritmo estatístico ADM-2, e limite de sensibilidade de 6.0 . 


\section{2.9. Ancestralidade Genômica}

Para avaliar a ancestralidade genômica das células, seu DNA foi extraído com o kit Flexigene DNA (Qiagen), e então enviado para o Laboratório Gene, coordenado pelo Prof. Sérgio Pena (MG), onde foram realizados os experimentos. Foi feita análise de 40 polimorfismos do tipo inserção/deleção em autossomos, como descrito por BastosRodrigues e colaboradores (2006).

\section{2.10. Tipagem HLA}

O DNA genômico das células foi extraído utilizando o kit FlexiGene DNA (Qiagen), e foi usado para tipagem dos loci HLA A, B, Cw, DRB1 e DAB1 em média resolução. Os experimentos foram realizados no Laboratório de Histocompatibilidade (UNIFESP, São Paulo), utilizando o sistema de tipagem LABType SSO, de acordo com especificações do fabricante (OneLambda, Inc).

Os dados obtidos foram comparados em baixa resolução, usando o software Sismatch, aos presentes no Registro Nacional de Doadores de Medula Óssea (REDOME), que contabilizava até o momento da análise (setembro de 2009) 1.312.334 indivíduos; a avaliação foi gentilmente realizada por Dra. Izabella Salomão (REREME Internacional - INCA). Dados referentes à tipagem HLA de linhagens de hESC derivadas por outros grupos de pesquisa foram retirados dos bancos de registro de hESCs americano (International Stem Cell Registry) e europeu (European Human Embryonic Stem Cell Registry), ou de artigos publicados (Josephson et al., 2006; Kumar et al., 2009). 


\section{Diferenciação das hESCs}

II. 2.11. Diferenciação in vitro - Formação de corpos embrióides (CEs)

Colônias de hESCs foram dissociadas e seus fragmentos foram cultivados em suspensão, em placas tratadas previamente com agarose $0,6 \%$ formando um filme para impedir a aderência dos fragmentos. $\mathrm{O}$ meio de cultura nos primeiros dias de cultivo foi o de manutenção das hESCs; no terceiro dia, os fragmentos foram transferidos para uma nova placa também tratada com agarose $0,6 \%$ contendo meio de diferenciação composto por $20 \%$ de SFB (Hyclone), $1 \%$ aminoácidos não-essenciais (Invitrogen), 2 mM Glutamax-I (Invitrogen), $1 \%$ piruvato de sódio, 1\% Hepes, $50 \mathrm{U} / \mathrm{mL}$ de penicilina e $50 \mathrm{mg} / \mathrm{mL}$ de estreptomicina, $0,1 \% \quad \beta$-mercaptoetanol em DMEM com alta concentração de glicose (DMEM high glucose - Invitrogen).

O meio de cultura foi trocado a cada três dias, da seguinte maneira: o meio contendo os CEs era passado pra um tubo cônico de $15 \mathrm{ml}$; após 5 minutos de sedimentação dos CEs no fundo do tubo, o meio era retirado com cuidado e ao precipitado de CEs era acrescentado meio novo.

Os CEs formados após cultivo por 14 dias em suspensão foram transferidos para câmaras em placas aderentes LabTeks (Nunc), tratadas anteriormente com gelatina $0,1 \%$, onde permaneceram por mais uma ou duas semanas.

As células diferenciadas foram então submetidas à reação de imunocitoquímica com anticorpos para detecção de proteínas específicas de cada um dos três folhetos embrionários. O protocolo de imunocitoquímica foi o mesmo relatado no item II.2.7, e os anticorpos utilizados foram: endoderme: SOX-17 e HNF-3ß (diluição 1:50 - Sta. Cruz Biotechnologies, Inc); mesoderme: $\alpha$-ACTININA (diluição 1:20 - Sigma) e MYOD (2 $\mu \mathrm{g} / \mathrm{ml}$ - BR Pharmigen); ectoderme: MAP2 (diluição 1:500 - Sigma) e NF200 
(diluído 1:400 -Sigma). Como anticorpos secundários foram utilizados antigoat IgGFITC (1:200) ou antimouse IgG-Cy3 (1:200), conforme a origem do primário.

\section{2.12. Diferenciação in vivo - formação de teratomas}

Diferentes metodologias para obtenção de teratomas foram testadas. Nelas, foram feitas combinações distintas entre: modo de aplicação das hESCs (células únicas ou grumos); meio de ressuspensão (PBS, PBS+30\% matrigel, mTeSR1 ou mTeSR1 + $30 \%$ matrigel); local da injeção das células no camundongo (subcutânea, cápsula renal ou intraocular); a linhagem de camundongo (SCID, Nude C57/B16 ou CD1). Além disso, foram utilizadas hESCs previamente cultivadas sob MEF ou matrigel.

O crescimento dos teratomas foi acompanhado durante 10-12 semanas, quando os camundongos foram sacrificados e os tumores foram removidos. Cada teratoma foi fixado em $4 \%$ paraformaldeído /4\% sacarose por 16 horas a $4{ }^{\circ} \mathrm{C}$, e em seguida foram mantidos em etanol $70 \%$ a $4{ }^{\circ} \mathrm{C}$. Os tumores foram incluídos em parafina, cortados em espessura de $4 \mu \mathrm{m}$, corados com hematoxilina-eosina, e analisados em microscopia.

\section{Expressão de genes "imprintados"}

Além de analisar o status da ICX, outro caráter acessado para verificar a estabilidade epigenética das linhagens de hESCs foi a expressão de genes "imprintados", que apresentam expressão monoalélica dependente da origem parental. A expressão alelo-específica de cada um dos genes foi investigada com o uso de uma ferramenta poderosa, baseada na existência de polimorfismos de base única (single nucleotide polymorphisms - SNPs) nas sequências codificadoras dos genes (cSNPs). Partindo de uma amostra informativa, ou seja, heterozigota na posição do cSNP, a 
expressão alelo-específica foi obtida por sequenciamento direto informando-nos o padrão de expressão, “imprintado" ou não.

II. 2.13. Seleção dos genes "imprintados"

Genes já descritos como "imprintados” em hESCs e que possuíssem cSNPs com índice de heterozigose maior que 0,3 foram selecionados em bancos de dados (VEGA, NCBI, Geneimprint). Dez genes "imprintados" foram selecionados e, com exceção do gene PEG10, cujas sequências de iniciadores foram retiradas de Kim e colaboradores (2007), nossa equipe confeccionou os iniciadores com o auxílio da ferramenta PrimerBlast (http://www.ncbi.nlm.nih.gov/tools/primer-blast/). A lista dos genes selecionados e a sequência de cada iniciador sintetizado encontram-se no Anexo 1.

\section{Genotipagem das células}

II. 2.14. Extração de ácidos nucleicos

As células mantidas em cultura foram dissociadas das placas por digestão com 0,25\% tripsina-EDTA, conforme descrito no item II.2.2. O precipitado foi congelado para posterior extração de ácidos nucleicos.

O DNA das células foi extraído com o kit FlexiGene DNA (Qiagen), conforme instruções do fabricante, quantificado e guardado a $-20{ }^{\circ} \mathrm{C}$. O RNA total foi obtido seguindo as instruções do kit RNeasy Mini (Qiagen), quantificado e estocado em freezer $-80{ }^{\circ} \mathrm{C}$.

\section{2.15. Síntese de cDNA}

Dez microgramas do RNA total foram tratados com a enzima Turbo DNA-free (Ambion); após tratamento, o RNA foi quantificado e $2 \mu \mathrm{g}$ foram utilizados na síntese 
de cDNA por transcrição reversa, realizada com o kit Superscript III (Invitrogen), utilizando 150 ng de iniciadores randômicos, conforme orientações do fabricante. Como controle dos tratamentos para eliminação de DNA genômico, amostras de RNA tratado onde não foi adicionada transcriptase reversa (RT-) eram também submetidas às RTPCRs (transcrição reversa seguida de PCRs).

\section{2.16. Amplificação por PCR ou RT-PCR}

Entre $50 \mathrm{ng}$ e $100 \mathrm{ng}$ de cDNA ou DNA foram amplificados utilizando $1 \mathrm{U}$ de Taq DNA Polimerase (Amersham), 1X tampão (Amersham), $150 \mathrm{nM}$ de cada iniciador, $200 \mu \mathrm{M}$ de dNTPs (Invitrogen), numa reação de volume final $15 \mu \mathrm{L}$. Para alguns pares de iniciadores, a reação ainda continha $10 \%$ DMSO ou 1 M de betaína; as condições de amplificação foram padronizadas pela aluna de mestrado do nosso laboratório Érica Sara Souza de Araújo.

O produto das amplificações (DNA e cDNA) foi aplicado em gel de agarose $1 \%$ 1X TAE, em solução $1 \mathrm{X}$ TAE, submetido à eletroforese a $100 \mathrm{~V}$ por 15 minutos. Os geis de agarose foram então corados com $0,5 \mu \mathrm{g} / \mathrm{mL}$ de brometo de etídeo (Invitrogen) e visualizados sob luz ultravioleta.

Amostras de RT- (controles da contaminação com DNA) também foram submetidas às RT-PCRs, para detecção de eventuais amplificações de DNA residual não eliminado no tratamento; após RT-PCR, essas amostras eram submetidas à eletroforese a $100 \mathrm{~V}$ em géis de poliacrilamida $10 \%$ 1X TBE, em solução $1 \mathrm{X}$ TBE. Após eletroforese, os géis foram mergulhados em solução fixadora (10\% etanol, 0,5\% ácido acético) por 10 minutos, imersos em solução de nitrato de prata $(2 \mathrm{~g} / \mathrm{L})$ por 8 minutos e posteriormente em solução reveladora $(\mathrm{NaOH} 30 \mathrm{~g} / \mathrm{L}$ e $0,002 \%$ de formaldeído $37 \%)$ até visualização das bandas (protocolo modificado de Santos et al., 1993). 


\section{2.17. Sequenciamento direto}

Os produtos das PCRs foram diluídos em água bidestilada autoclavada, na proporção 1:6 ou 1:4, conforme intensidade da banda observada no gel. Os produtos das RT-PCRs foram submetidos à purificação com solução 1 X PEG (4,92 g acetato de sódio; 0,12 g $\mathrm{MgCl}_{2} \cdot 6 \mathrm{H}_{2} \mathrm{O} ; 26,2$ g PEG800); após incubação a temperatura ambiente por 10 minutos, as amostras foram centrifugadas a temperatura ambiente por 10 minutos a $14000 \mathrm{rpm}$. O sobrenadante foi retirado e em seguida foram acrescentados aos precipitados $100 \mu \mathrm{l}$ de etanol 96\%. Nova centrifugação foi realizada, o sobrenadante foi eliminado, os precipitados foram secos a temperatura ambiente e ressuspendidos em 3 $\mu \mathrm{L}$ de água bidestilada autoclavada.

Os produtos diluídos e os purificados com solução PEG foram submetidos à reação de sequenciamento direto, utilizando iniciador $\mathrm{F}$ (forward) ou $\mathrm{R}$ (reverse). Assim, $1 \mu \mathrm{L}$ de cada amostra foi usado na reação com $1 \mu \mathrm{L}$ de BigDye $\mathbb{B}$ Terminator v3.1 do kit Cycle Sequencing (Applied Biosystems), 1X tampão, 120 nM de iniciador, num volume final de $15 \mu \mathrm{L}$. O programa para reação de sequenciamento consistia em 40 ciclos de $96{ }^{\circ} \mathrm{C}$ por 10 segundos; $52{ }^{\circ} \mathrm{C}$ por 20 segundos; $60{ }^{\circ} \mathrm{C}$ por 4 minutos, como recomendado pela Applied Biosystems.

O produto das reações de sequenciamento foi purificado em colunas Sephadex, de acordo com orientações do fabricante (Amersham), e ressuspendidos em $10 \mu \mathrm{L}$ de formamida (Applied Biosystems). A eletroforese capilar das amostras foi realizada em sequenciador ABI3100 Prism Genetic Analyzer (Applied Biosystems), do Departamento de Parasitologia do Instituto de Ciências Biomédicas USP, de acordo com as configurações do fabricante (Técnico Responsável: Marcio Massao Yamamoto).

Vale lembrar que a genotipagem das células BR-1 foi feita pela deCODE (deCODEme) Genetics Company (EUA). 


\section{Análise da inativação do cromossomo X}

\section{2.18. FISH de RNA}

Células indiferenciadas e diferenciadas após formação de corpos embrióides CEs (ver item II.2.11) foram submetidas a ensaios de FISH de RNA, para detecção do transcrito de XIST. Três sondas referentes a três porções do cDNA de XIST já foram testadas previamente no nosso laboratório pela Dra. Raquel Stabellini, e uma delas foi selecionada por produzir um sinal de marcação intenso e gerar menos marcação inespecífica (Stabellini, 2008). Os plasmídeos contendo esses fragmentos de cDNA clonados foram gentilmente cedidos pelo Dr. Brian Hendrich, da Case Western Reserve University (EUA).

Células plaqueadas em lamínula de vidro ou câmaras LabTeks (Nunc) foram submetidas a lavagens seriadas [5 minutos com PBS gelado, 30 segundos com tampão CSK (100 mM NaCl, $300 \mathrm{mM}$ sacarose, $10 \mathrm{mM}$ PIPES, $3 \mathrm{mM} \mathrm{MgCl}$ ), 1 minuto com CSK/0,5 \% Triton, 1 minuto com CSK, e fixadas com 4\% PFA 20 minutos a $37^{\circ} \mathrm{C}$ ]. Após uma lavagem com etanol 70\% gelado por 5 minutos, as células foram desidratadas em banhos seguidos de etanol $80 \%, 90 \%$ e $100 \%$ por 2 minutos cada. As lâminas secas foram incubadas com a solução de hibridação [2X SSC; $50 \%$ formamida; $10 \%$ dextran sulfato; $2 \mathrm{mM}$ vanadil ribonucleosídeo (Invitrogen); 0,02\% BSA; $1 \mu \mathrm{g} / \mathrm{mL}$ tRNA de levedura (Invitrogen)] com 200 ng de sonda previamente marcada com o kit Dig Nick Translation conforme instruções do fabricante (Roche), desnaturada por 5 minutos a 95 ${ }^{\circ} \mathrm{C}$. A hibridação foi feita por 16 horas a $37^{\circ} \mathrm{C}$ em câmara úmida com solução $2 \mathrm{X}$ SSC, $50 \%$ formamida.

No dia seguinte, as células foram lavadas por 2 vezes de 5 minutos cada com solução $2 \mathrm{X} \mathrm{SSC}, 50 \%$ formamida a $45^{\circ} \mathrm{C}$, e 2 vezes 5 minutos com $2 \mathrm{X}$ SSC a $45^{\circ} \mathrm{C}$. Após um bloqueio por 10 minutos em solução $1 \%$ BSA, 2X SSC, 2 mM vanadil 
ribonucleosídeo e $1 \mu \mathrm{g} / \mathrm{ml}$ tRNA de levedura (Invitrogen), as células foram incubadas com anticorpo anti-digoxigenina conjugado à rodamina (Roche) na proporção 1:50 em solução $2 \mathrm{X}$ SSC, $2 \mathrm{mM}$ vanadil, $1 \%$ BSA por 30 minutos no escuro. A lamínula com as células foi em seguida lavada 2 vezes por 5 minutos cada com uma solução $4 \mathrm{X} \mathrm{SSC/} 0,1$ $\%$ Tween a $45^{\circ} \mathrm{C}$, e montada em lâmina com Vectashield-DAPI. A análise foi feita em microscópio de fluorescência Axiophot 2 (Carl Zeiss, Oberkochen, Alemanha), do Laboratório de Genética Humana II (Departamento de Genética e Biologia Evolutiva do IB-USP). Para documentação, as imagens foram capturadas por câmara CCD e processadas utilizando-se o software ISIS (MetaSystem, Altlussheim, Alemanha). Em todos os experimentos foram incluídos controles sem sonda, somente com o anticorpo anti-digoxigenina e um controle somente com Vectashield-DAPI.

\section{2.19. Expressão de XIST por RT-PCR em tempo real}

Foi avaliada a expressão do gene XIST por RT-PCR em tempo real em hESCs antes e após diferenciação. O cDNA das células foi sintetizado a partir do RNA tratado para eliminação de DNA genômico, segundo protocolos descritos nos itens II.2.14 e II.2.15.

Vinte e cinco nanogramas de cDNA foram amplificados usando 1X TaqMan Universal PCR Master Mix ou 1X SYBR Green PCR Master Mix (Applied Biosystems). Em todas as amplificações realizadas, foram utilizados os parâmetros universais de ciclagem $\left[50{ }^{\circ} \mathrm{C} / 2 \mathrm{~min} ; 95^{\circ} \mathrm{C} / 10 \mathrm{~min} ; 40\right.$ ciclos $\left(95{ }^{\circ} \mathrm{C} / 15 \mathrm{seg} ; 60{ }^{\circ} \mathrm{C} / 1\right.$ min)], e ao final de cada reação foram realizadas curvas de dissociação para controle de possíveis contaminações. 
Para expressão do gene XIST, foi obtido da Applied Biosystems o ensaio para sistema Taqman (ID Hs01079824_m1, sonda FAM/MGB). A padronização deste ensaio foi feita pela Dra. Raquel Stabellini durante seu doutoramento. Para normalização da expressão gênica, foram selecionados alguns genes de controle endógeno; pares de iniciadores foram desenhados com o auxílio da ferramenta PrimerExpress (Applied Biosystems), ou sintetizados a partir da sequência disponível em artigos (Vandesompele et al., 2002; Wikman et al., 2002; Zhao et al., 2003) para serem utilizados em ensaios com SYBR Green Master Mix. Diversos genes foram testados como normalizadores das reações. Os mais estáveis de acordo com o software geNorm VBA para Excel (Vandesompele et al., 2002) foram mantidos, e a expressão de XIST foi comparada entre as amostras de acordo com orientações do aplicativo. Os genes e a sequência de seus iniciadores são:

HMBS F - 5' CTGGAAGGAGGCTGCAGTGT 3'

HMBS R - 5' TACAGTTGCCCATCCTTCATAGC 3'

TOP1 F - 5' TCCGGAACCAGTATCGAGAAGA 3'

TOP1 R - 5' CCTCCTTTTCATTGCCTGCTC 3'

YWHAZ F - 5' AAACCAACAGCGACTTGGAAGCAC 3'

YWHAZ R - 5' GTGCTTCCAAGTCGCTGTTGGTTT 3'

B2M F - 5' CACCCCCACTGAAAAAGATG 3'

B2M R - 5' ATATTAAAAAGCAAGCAAGCAGA 3'

SDHA F - 5' TGGGAACAAGAGGGCATCTG 3'

SDHA R - 5' CCACCACTGGATCAAATTCATG 3'

TBP F- 5' TTCGGAGAGTTCTGGGATTGTA 3'

TBP R - 5' TGGACTGTTCTTCACTCTTGGC 3'

UBC F - 5' ATTTGGGTCGCGGTTCTTG 3'

UBC R - 5' TGCCTTGACATTCTCGATGGT 3' 


\section{2.20. Imunocitoquímica para detecção da H3K27me3}

Células BR-5 indiferenciadas e diferenciadas foram cultivadas em placas de 24 poços, contendo lamínulas de vidro, ou então em câmaras de LabTeks (Nunc). Após 5 dias de cultivo, o meio de cultura foi retirado, as células foram lavadas 2 vezes com PBS (Invitrogen), fixadas com paraformaldeído (PFA) $4 \%$ por 10 minutos e depois lavadas com PBS. As células foram permeabilizadas com solução de PBS 0,1\% Triton X-100 (Sigma) por 5 minutos, incubadas com solução de bloqueio (PBS +1\% SFBCultilab $+0,1 \%$ Triton $\mathrm{X} 100)$ por uma hora, e em seguida com o anticorpo antiH3K27me3 (Millipore) diluído em solução de bloqueio (1:200), durante 16 horas a 4 ${ }^{\circ} \mathrm{C}$. No dia seguinte, as soluções com anticorpo foram retiradas e as células foram lavadas três vezes com PBS/0,1\% Triton por 5 cinco minutos cada. Em seguida, as células foram incubadas com anticorpo secundário antimouse IgG Alexafluor 488 ou antirabbit Alexafluor 594 (Invitrogen) diluído em solução de bloqueio (1:1000) por uma hora a temperatura ambiente. As lâminas foram lavadas 4 vezes com PBS por 5 minutos a temperatura ambiente, e montadas em meio Vectashield contendo DAPI (Vector Laboratories, Inc.). Os experimentos foram padronizados pela Dra. Simone Fonseca.

As células foram observadas em microscópio de fluorescência Axiophot 2 (Carl Zeiss, Oberkochen, Alemanha), do Laboratório de Genética Humana II (IB-USP). Para documentação, as imagens foram capturadas por câmera CCD e processadas utilizandose o software ISIS (MetaSystem, Altlussheim, Alemanha). 


\section{3. RESULTADOS}

\section{Caracterização de linhagens de hESC quanto à ICX}

Um dos objetivos deste trabalho foi verificar o potencial das hESCs como modelos de estudo do início da ICX em humanos. Para isso, procurou-se avaliar o status da ICX em algumas linhagens de hESCs estabelecidas por outros pesquisadores e derivadas em nosso laboratório.

As linhagens HUES-1 (passagem 21 - p21), HUES-9 (p19), HUES-14 (p16) e HUES-15 (p14), derivadas por Cowan e colaboradores (2004), foram inicialmente cultivadas sob as condições de cultivo recomendadas pelos pesquisadores (meio de manutenção hESC "A" - Tabela 1), e depois adaptadas ao cultivo com matrigel e mTeSR1. Todas as linhagens são femininas e cariotipicamente normais (46,XX), com exceção da linhagem HUES-9 que possui uma inversão no cromossomo 9. A linhagem HUES-15 não pôde ser recuperada após o descongelamento, por isso não foi possível utilizá-la nos experimentos subsequentes. Foram obtidas alíquotas de células nas passagens mais iniciais possíveis, para se evitar uma possível perda de pluripotência ao longo do tempo de cultivo.

A Figura 6 mostra o resultado do RNA-FISH usando sonda contra o transcrito de XIST. Como as mESCs, as três linhagens indiferenciadas não expressavam XIST. Porém, após diferenciação in vitro com a formação de corpos embrióides (CEs), elas continuaram não expressando XIST. 

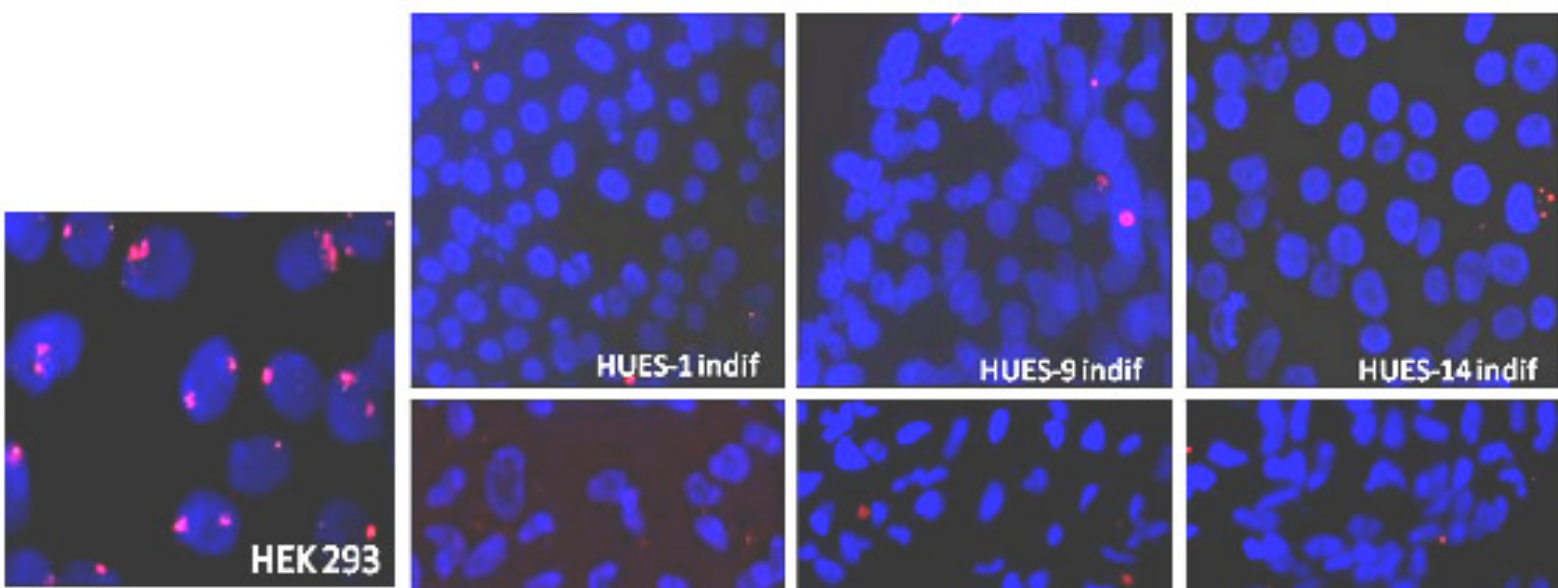

HUES-1 pós CE
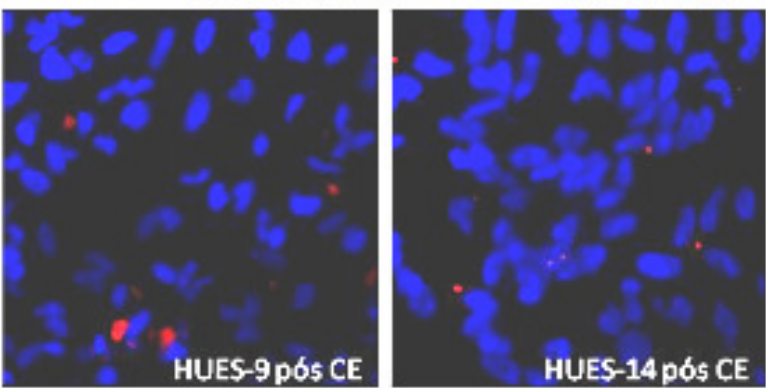

Figura 6: Células HUES não expressam XIST após diferenciação. FISH de RNA utilizando sonda contra o transcrito do gene XIST, realizado em três linhagens de hESC antes e após diferenciação espontânea por formação de corpos embrióides (CEs). Em rosa, marcação contra RNA de XIST. Em azul, núcleo corado com DAPI. Não foi detectado sinal do transcrito de XIST em nenhuma linhagem analisada, tanto antes quanto após a diferenciação. Células HEK293 (aneuplóides) foram usadas como controle positivo.

Derivação de novas linhagens de hESC

Com o intuito de explorar a capacidade das hESC de servirem como modelos de estudo do início da ICX, tentamos estabelecer em nosso laboratório novas linhagens de hESCs. Amparados pela lei de Biossegurança de 2005, embriões humanos congelados há mais de três anos e doados para pesquisa com o consentimento dos pais foram disponibilizados por duas clínicas de fertilização assistida de São Paulo: Fertility Centro de Reprodução Assistida (São Paulo) e Centro de Reprodução Humana Prof. Franco Jr, de Ribeirão Preto. Esses embriões foram congelados no dia 3 (d3) após fecundação e doados pelos pais biológicos para pesquisa.

As tentativas de derivação de novas linhagens de hESC foram realizadas em três ocasiões. Em cada uma delas, diferentes metodologias foram empregadas, baseadas 
principalmente nas diferentes condições de cultivo possíveis (meios de cultura para derivações diferentes, presença ou não de feeder - ver Tabela 1).

A primeira tentativa contou com a colaboração dos pesquisadores Marina Soukoian e Ric Ross (Burnham Institute, La Jolla, CA, EUA). Dos 53 embriões descongelados, 42 degeneraram e somente 11 chegaram ao estágio de blastocisto. Nesta tentativa, a MCI foi isolada no micromanipulador, com auxílio de lâminas que foram acopladas ao aparato. Após o isolamento, as células da MCI foram semeadas sobre camada de fibroblastos humanos de prepúcio (HS27-ATCC) irradiados, e mantidas em meio de cultura de derivação I (ver Tabela 1). Das 11 MCI isoladas, 10 aderiram na placa e expandiram, sendo mantidas por mais de seis meses em cultura. No entanto, a morfologia das colônias obtidas diferia consideravelmente daquela esperada para hESC (Figura 7), e o tempo de duplicação das células era muito longo, o que inviabilizou experimentos de caracterização posteriores. Por esta razão, estas células foram congeladas e seguiu-se uma nova tentativa de derivação.
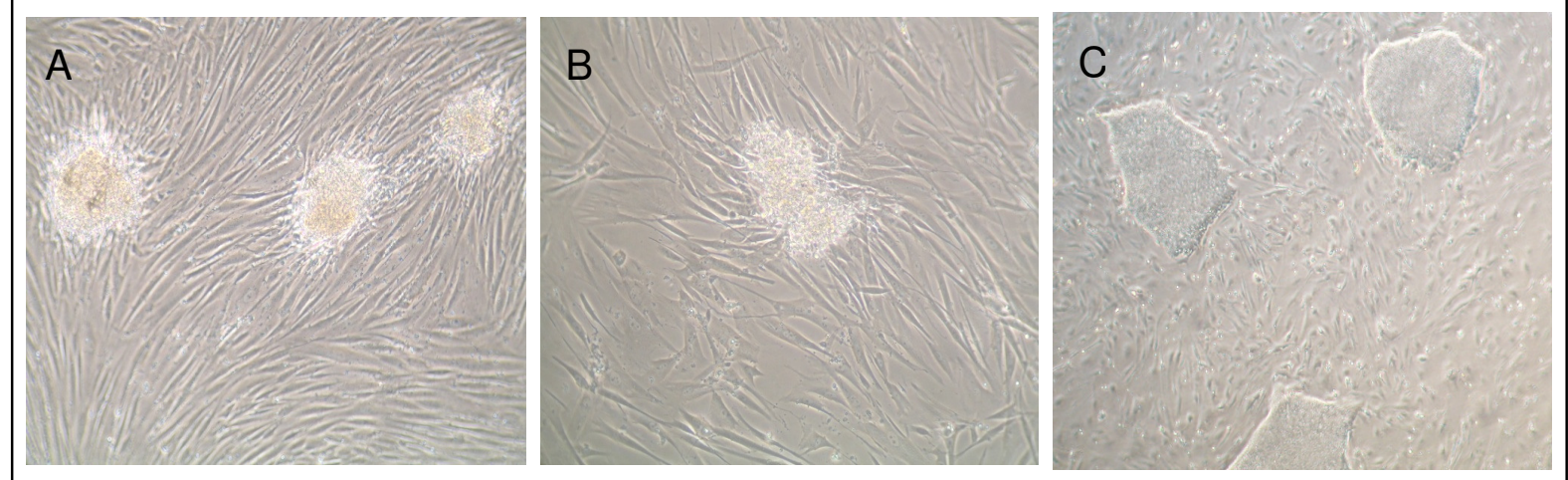

Figura 7: Estabelecimento de linhagens de hESC, utilizando feeder humano. A tentativa de derivação resultou na formação de colônias de crescimento lento e morfologicamente distintas (A e B) das já descritas linhagens de hESC (C). Em C, colônias da linhagem HUES9, estabelecidas por Cowan e colaboradores (2004), sobre camada de feeder.

Em nossa segunda tentativa, realizada na clínica do Prof. Franco Jr. (Ribeirão Preto), dos 195 embriões descongelados, 19 chegaram ao estágio de blastocisto e destes a MCI foi isolada mecanicamente por cortes feitos com agulhas de insulina visualizados 
sob lupa. Desta vez, foi utilizado como feeder MEFs irradiados e meio de derivação II (Tabela 1). Este meio leva em sua formulação 2,5\% SFB (Hyclone) para promover a adesão da MCI na placa, mas essa porcentagem foi gradualmente diminuída. Nenhuma linhagem foi obtida, pois a maior parte das massas celulares isoladas não aderiu à placa com MEFs irradiados, e as que aderiram degeneraram com o passar do tempo em cultura.

Na terceira tentativa, utilizamos matrigel como substrato para as células e o meio definido mTeSR1 para a derivação, baseado em trabalho onde se derivaram duas linhagens de hESCs empregando estratégia parecida, com meio definido e matriz acelular como suporte (Ludwig et al., 2006). Ao todo, setenta e nove embriões foram utilizados, dos quais quarenta e cinco atingiram o estágio de blastocisto. No entanto, a baixa qualidade dos embriões não permitiu o isolamento da maioria das MCIs: somente cinco blastocistos tiveram as MCIs removidas com agulha de insulina. As MCIs isoladas $(n=5)$ ou os blastocistos inteiros $(n=40)$ foram plaqueados em matrigel e mTeSR1 (meio de derivação III - Tabela1).

Vinte e um blastocistos (3 com ICM isolada e 18 plaqueados inteiros) aderiram nas placas e expandiram em cultura. Após 6 dias, foram adicionados MEFs irradiados a sete culturas remanescentes, e em duas (proveniente de blastocistos plaqueados inteiros) foi possível realizar a primeira passagem mecânica para novas placas com matrigel. Em uma dessas culturas as células degeneraram após a primeira passagem, mas em outra as células continuaram expandindo; na Figura 8 pode-se observar os primeiros dias de cultivo e expansão destas células. 


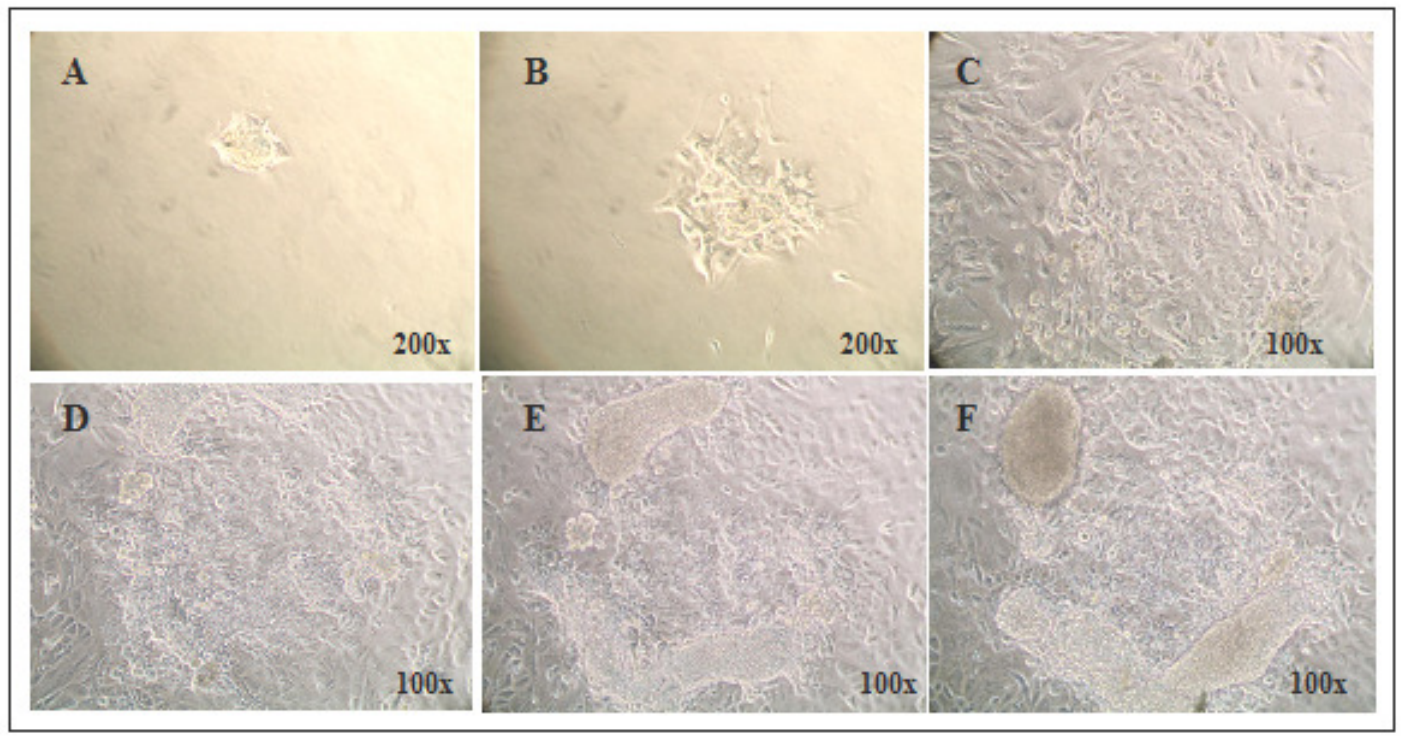

Figura 8: Estabelecimento da linhagem de hESC BR-1. Em A, segundo dia após o plaquemento do blastocisto inteiro, sem zona pelúcida; de B a F, dias 4, 8 (após plaquemento do feeder), 10, 11 e 12 de cultivo. As imagens foram feitas em microscopia com contraste de fase, e os aumentos estão especificados.

A partir da segunda passagem (p2), colônias compactas típicas de hESC já puderam ser observadas, com células exibindo alta relação de núcleo/citoplasma. A partir da p3 as células foram passadas a cada 6-8 dias para placas com e sem feeder. A subpopulação mantida em matrigel foi caracterizada, e a linhagem foi nomeada BR-1. A Figura 9 mostra imagens das células BR-1 desde o plaqueamento inicial até a passagem $28(\mathrm{p} 28)$.

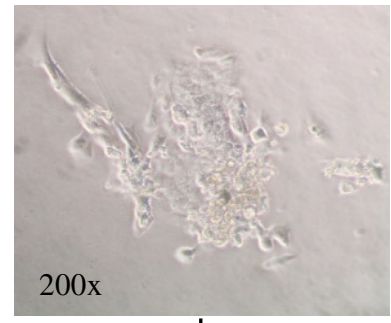

Dia $5-\mathrm{p} 0$

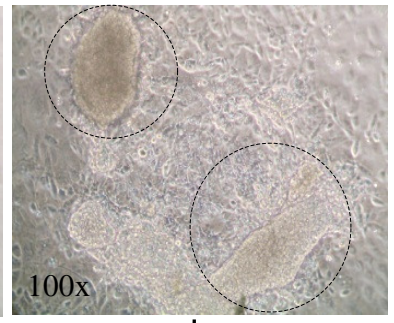

Dia $12-\mathrm{p} 0$
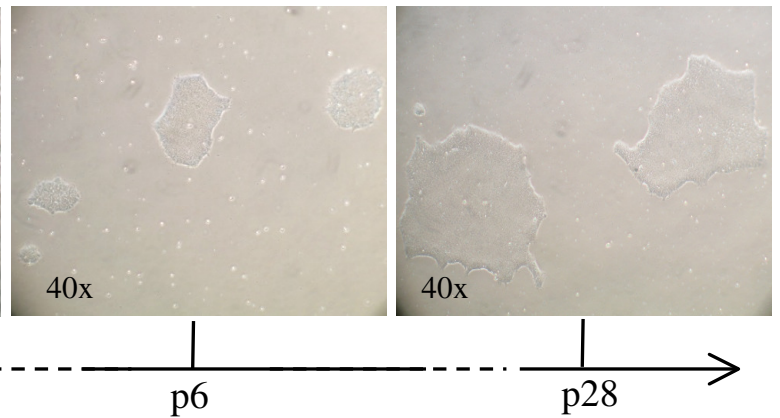

Figura 9: Aspectos morfológicos das células BR-1. As imagens foram feitas em microscopia com contraste de fase, e representam as etapas da derivação da BR-1. Os campos delimitados na imagem referente ao dia 12 (p0) correspondem às áreas de maior crescimento celular, escolhidas para as passagens subsequentes. Os aumentos estão especificados. 
Caracterização da linhagem de hESC BR-1

As células foram testadas quanto à expressão de antígenos relacionados à pluripotência por imunofluorescência; as células da linhagem BR-1 expressam OCT-4, TRA-1-60, TRA-1-81 e SSEA-4, todos marcadores de pluripotência característicos de hESC (Figura 10).

A estabilidade cromossômica das células BR-1 foi testada por cariotipagem convencional com bandeamento $\mathrm{G}$ e por array genômico (CGH-array). Os resultados dessas análises podem ser visualizados na Figura 11. Pelo menos 20 metáfases foram utilizadas para análise de cariótipo por bandeamento $\mathrm{G}$, com células em passagens iniciais (p5) e tardias (p29). Todas as células exibiram uma constituição cariotípica normal 46,XY. O resultado do array genômico (com resolução de $70 \mathrm{~Kb}$ ) feito com a linhagem BR-1 em p27 mostrou que não houve perda nem ganho cromossômico nestas células mesmo após cultivo contínuo durante 6 meses.
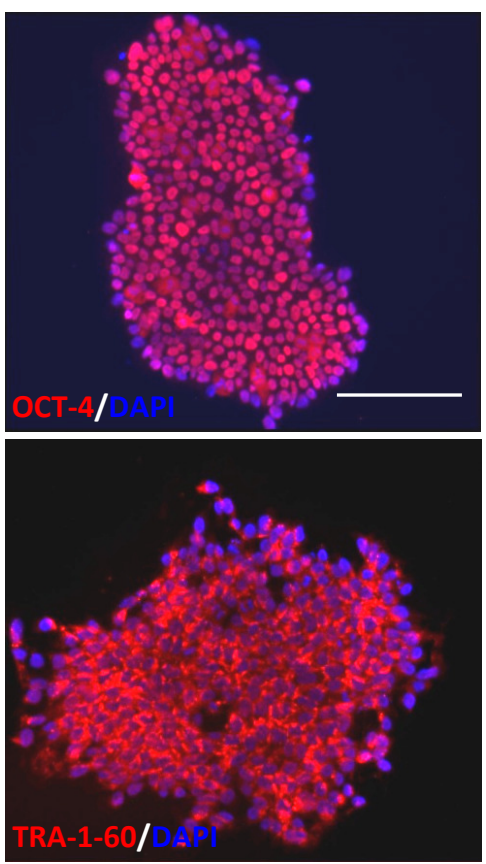
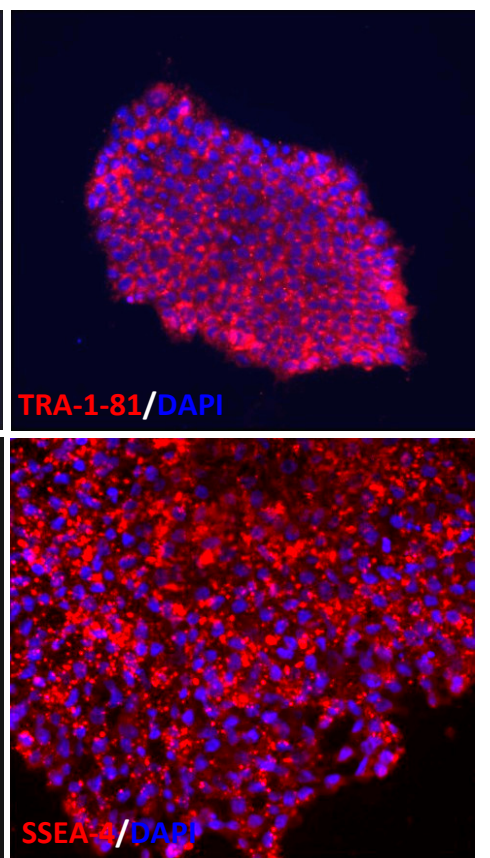

Figura 10: Células BR-1 expressam marcadores de pluripotência. Imunocitoquímica com anticorpos para OCT-4, TRA-1-81, TRA-1-60 e SSEA-4. Em azul, marcação nuclear com DAPI. Em vermelho, marcação com os anticorpos assinalados, incubados com anti-IgG de camundongo conjugado com Cy-3 como anticorpo secundário. Barra de escala: $100 \mu \mathrm{m}$. 

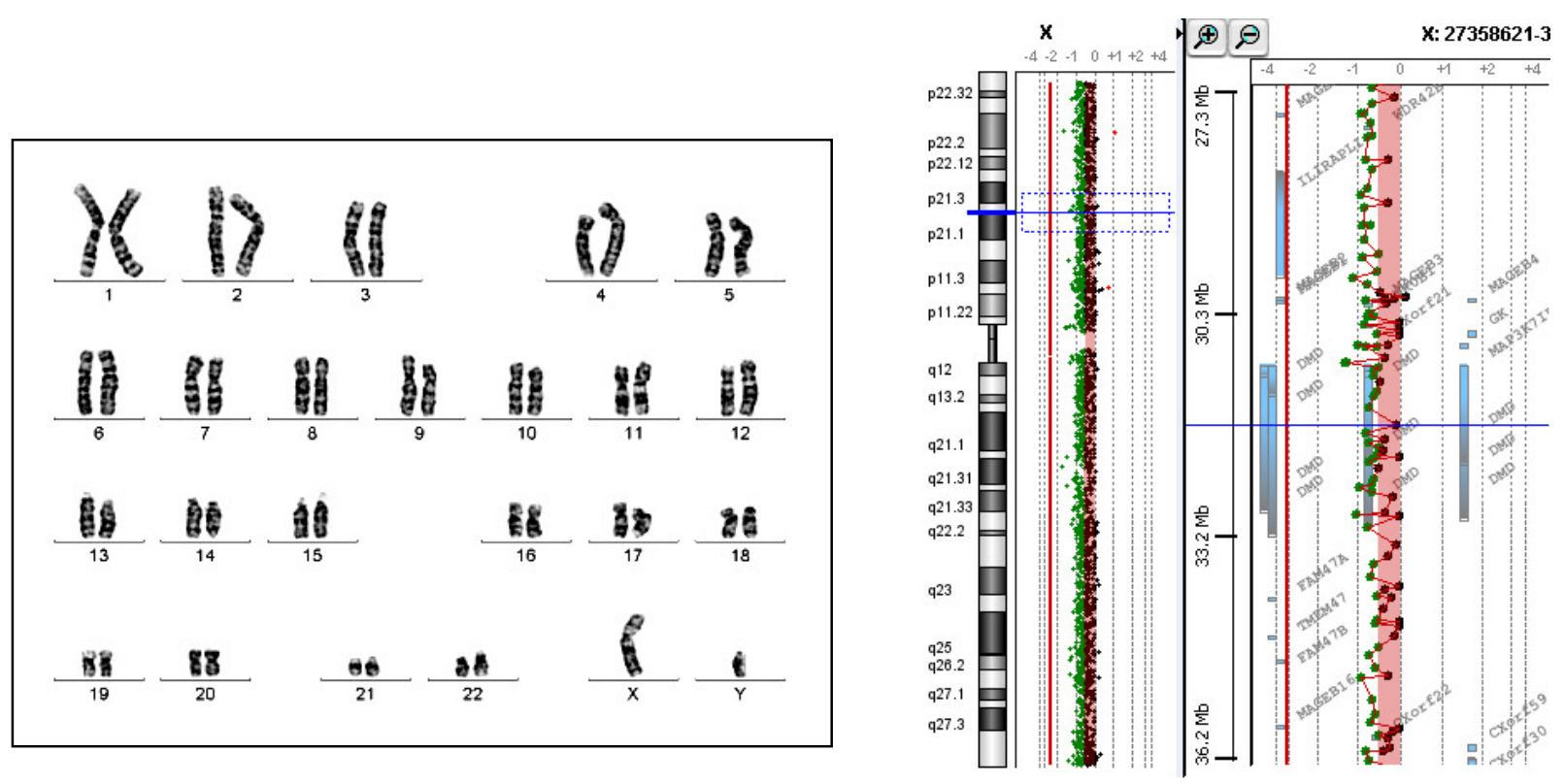

Figura 11: Estabilidade genômica da linhagem de hESC BR-1 após seis meses em cultura. À esquerda, cariótipo avaliado por bandeamento $\mathrm{G}$ em células em passagem tardia (p29) revelou constituição cariotípica normal $(46, \mathrm{XY})$. À direita, diagrama representativo do cromossomo $\mathrm{X}$ obtido pelo array genômico, mostrando desequilíbrio entre a linhagem BR-1 (pontos em vermelho - Cy3) e as células usadas como referência (fibroblastos humanos 46,XX - pontos em verde - Cy5). Em detalhe (pontilhado azul), região ampliada do diagrama mostrando em detalhe a localização de alguns genes.

As células BR-1 são capazes de originar derivados dos três folhetos embrionários tanto in vitro - após formação de corpos embrióides (CEs) - quanto in vivo, quando injetadas em camundongos imunodeficientes, pois são capazes de formar teratomas. A Figura 12 mostra os resultados de imunocitoquímica das células BR-1 diferenciadas in vitro, confirmando a expressão de marcadores de endoderme, mesoderme e ectoderme. 

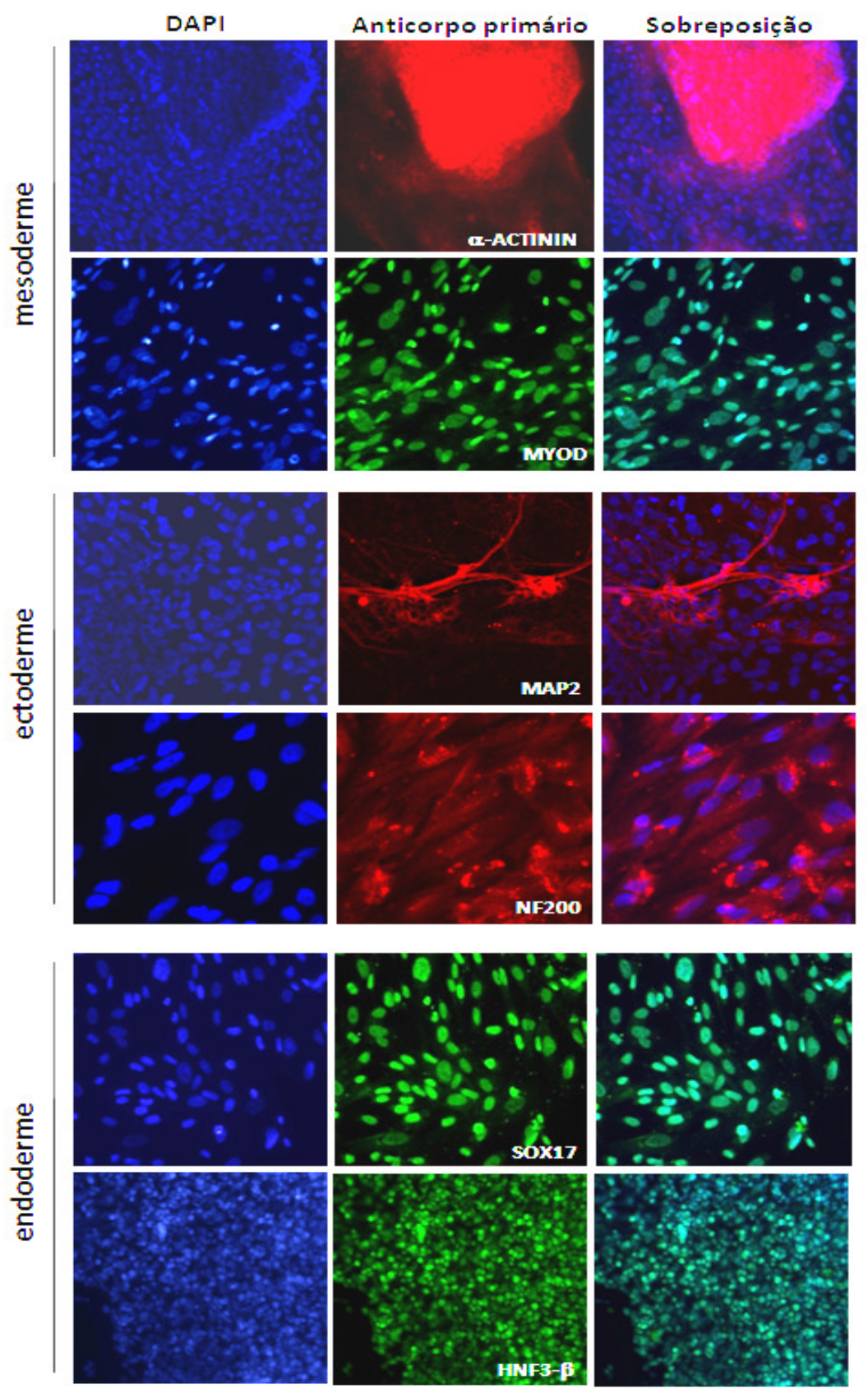

Figura 12: Diferenciação espontânea in vitro de células BR-1 produz células diferenciadas, derivadas dos três folhetos embrionários. Na primeira coluna, núcleos corados com DAPI. Na coluna do meio, marcação das células incubadas com os anticorpos especificados. À direita sobreposição das imagens. Os antígenos contra MAP2, $\alpha$-ACTININ e NF200 foram detectados usando como anticorpo secundário anti-IgG Cy3, e HNF3- $\beta$, SOX17 e MYOD foram detectados utilizando como secundário anti-IgG FITC. 
Várias tentativas infrutíferas de formação de teratomas foram realizadas. Havia a suspeita de que hESCs cultivadas sem feeder murino (o caso das BR-1) tinham baixa eficiência de formação de teratomas (James Thomson, comunicação pessoal). Assim, na última tentativa, células BR-1 foram cultivadas durante duas semanas na presença de feeder murino irradiado; a aplicação de grumos de células indiferenciadas, aliada ao uso de 30\% de matrigel na mistura de aplicação e à inoculação subcutânea em camundongos Nude C57/B16 rendeu-nos resultados, e tumores e cistos começaram a ser observados seis semanas após a inoculação. Análises histológicas dos tumores isolados foram realizadas, revelando a existência de células de origem mesodérmica, endodérmica e ectodérmica (Figura 13).
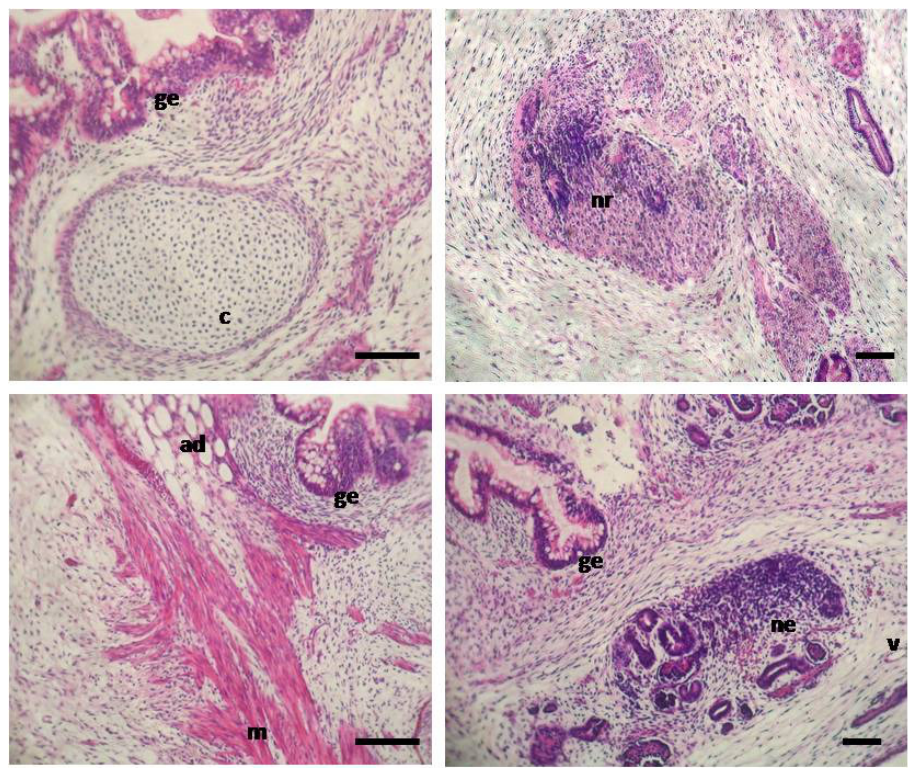

Figura 13: Células BR-1 formam teratomas quando injetadas em camundongos. A análise histológica de cortes dos tumores derivados das células BR-1, corados em hematoxilina-eosina revelou a presença de derivados dos três folhetos embrionários: ad - tecido adiposo; c - cartilagem; ge - epitélio glandular; m - músculo; ne - epitélio neural; $\mathrm{nr}$ - rosetas neurais; v -vasos. As barras de escala equivalem a $100 \mu \mathrm{m}$.

Devido a grande heterogeneidade genética da população brasileira (Alves-Silva et al., 2000), esperar-se-ia que a linhagem BR-1 contribuísse com a diversidade genética de linhagens de hESC disponíveis para pesquisa em terapia, atendendo a demanda da população brasileira. Para responder essa pergunta, foi realizada a tipagem dos antígenos leucócitários humanos (HLA) nas células BR-1. O perfil HLA das células 
BR-1, juntamente com o de outras linhagens de hESCs, foi comparados aos dos potenciais doadores de medula óssea do REDOME (Registro Nacional de Doadores de Medula Óssea). Os dados são apresentados na Tabela 2, e podemos observar que não há compatibilidade (match) entre as células BR-1 e os mais de um milhão e 300 mil doadores de medula óssea brasileiros registrados no REDOME até o momento da análise.

A ancestralidade genômica da linhagem BR-1 foi verificada pela genotipagem de 40 polimorfismos in-del, realizada pelo grupo do Prof. Dr. Sérgio Pena (MG); a análise revelou que as células possuem $98,4 \%$ de contribuição européia, 0,8\% de ameríndia e 0,8\% de africana. A Tabela 3 mostra esses valores, comparando-os com os da linhagem de hESCs H1, derivada por Thomson e colaboradores (1998).

Tabela 2: Compatibilidade entre o perfil HLA de diferentes linhagens de hESCs com os dados do REDOME.

\begin{tabular}{|c|c|c|c|c|c|c|c|}
\hline $\begin{array}{c}\text { Linhagem } \\
\text { hESC }\end{array}$ & $\begin{array}{c}\text { Origem } \\
\text { (país) }\end{array}$ & $\begin{array}{c}\text { HLA- } \\
\text { A }\end{array}$ & $\begin{array}{c}\text { HLA- } \\
\text { B } \\
\end{array}$ & $\begin{array}{l}\text { HLA- } \\
\text { C(w) }\end{array}$ & $\begin{array}{l}\text { HLA- } \\
\text { DRB1 }\end{array}$ & HLA-DQB1 & $\begin{array}{c}\text { REDOME } \\
\text { match }^{\natural}\end{array}$ \\
\hline $\mathrm{BG} 01^{\dagger}$ & EUA & 0203 & 3549 & 0407 & 0304 & 0203 & 6 \\
\hline $\mathrm{BG} 02^{\dagger}$ & EUA & 2468 & 3535 & 0304 & 1516 & 0306 & 2 \\
\hline $\mathrm{BG}^{\dagger} 3^{\dagger}$ & EUA & 0232 & $44-$ & $05-$ & $04-$ & 0303 & - \\
\hline ES-4* & Espanha & 0232 & 1444 & 0508 & 1313 & 0306 & - \\
\hline ES-6* & Espanha & 0124 & 1527 & 0203 & 1113 & 0306 & - \\
\hline H1 $(\mathrm{WA} 01)^{\dagger}$ & EUA & 0203 & 0835 & 0407 & 0103 & 0205 & 51 \\
\hline $\mathrm{H} 7(\mathrm{WA} 07)^{\dagger}$ & EUA & 0225 & 1835 & 0412 & 0711 & 0203 & 5 \\
\hline H9 (WA09) ${ }^{\dagger}$ & EUA & 0203 & 3544 & 0407 & 1516 & 0506 & 3 \\
\hline H13 (WA13) ${ }^{\dagger}$ & EUA & 0325 & 0718 & 0712 & 0107 & 0205 & - \\
\hline H14 (WA14) ${ }^{\dagger}$ & EUA & 0325 & 0718 & 0712 & 0107 & 0205 & - \\
\hline HES- $1^{\dagger}$ & Cingapura & 1124 & 1535 & 0812 & 1415 & 0506 & - \\
\hline HES- $2^{\dagger}$ & Cingapura & 0202 & 4648 & 0108 & 0415 & 0406 & - \\
\hline HES- $3^{\dagger}$ & Cingapura & 1133 & 4055 & 0107 & $12-$ & 0306 & - \\
\hline HES- $4^{\dagger}$ & Cingapura & 0203 & 1544 & 0316 & 0407 & 0203 & 58 \\
\hline HSF- $1^{\dagger}$ & EUA & $11-$ & 1551 & 0814 & 1113 & $03-$ & - \\
\hline $\mathrm{HUES}^{\dagger}$ & EUA & 0203 & 3551 & 0414 & 0415 & 0306 & 24 \\
\hline $\mathrm{I} 4^{\dagger}$ & Israel & 0324 & 3538 & 0412 & $13-$ & $06-$ & - \\
\hline $\mathrm{I}^{\dagger}$ & Israel & 0126 & 3844 & 0412 & 0407 & 0203 & - \\
\hline KIND-1 ${ }^{\#}$ & India & 1129 & 0735 & 0415 & 1007 & $03-$ & - \\
\hline KIND-2 $2^{\#}$ & India & 0130 & 3540 & 1512 & 1415 & 0506 & - \\
\hline $\mathrm{SA} 01^{\dagger}$ & Suécia & 0102 & 0735 & 0407 & 1315 & 0606 & - \\
\hline $\mathrm{SA} 02^{\dagger}$ & Suécia & 0123 & 0751 & 0715 & 14 - & $05-$ & - \\
\hline BR-1 & Brasil & 2368 & 0751 & 0714 & 1215 & 0506 & - \\
\hline
\end{tabular}

"compatibilidade completa em baixa resolução; *de acordo com o European Human Embryonic Stem Cell Registry; ${ }^{\dagger}$ de acordo com o International Stem Cell Registry; ${ }^{~ K u m a r ~ e t ~ a l ., ~} 2009$. REDOME: Registro Nacional de Doadores de Medula Óssea. 
Tabela 3: Ancestralidade genômica das células BR-1 e H1.

BR-1

H1

Européia $0.984(0.898-1.000) 0.960(0.836-1.000)$

Ameríndia $0.008(0.000-0.042) 0.005(0.000-0.036)$

Africana $0.008(0.000-0.053) 0.035(0.000-0.128)$

Os valores são porcentagens de cada contribuição (intervalo de confiança)

A derivação e a caracterização da linhagem de hESC BR-1, a primeira derivada na América Latina, resultou em publicação (Anexo 3). Além disso, as células foram incluídas em um estudo internacional organizado pela International Stem Cell Initiative (Anexo 4).

Derivação de novas linhagens de hESC

Como o objetivo deste trabalho era investigar o início da ICX em hESCs e a linhagem BR-1 é XY, nossos esforços para derivar novas linhagens continuaram. Até o momento, mais três linhagens (BR-2, BR-4 e BR-5) foram estabelecidas e estão sendo caracterizadas por integrantes do nosso grupo.

A análise de cariótipo das células BR-2 revelou que se trata de uma linhagem triplóide (69,XXX); já BR-4 e BR-5 são euplóides, sendo que BR-4 é 46,XY e BR-5 é 46,XX. Por ser uma linhagem euplóide feminina, este trabalho pretendeu verificar o status de ICX na linhagem BR-5. É fundamental esclarecer que tanto BR-4 quanto BR5 foram derivadas utilizando o meio de derivação II sob concentrações fisiológicas de oxigênio (5\%). Baseados na publicação de Lengner e colaboradores (2010), que relataram que a derivação de linhagens de hESCs em níveis fisiológicos de $\mathrm{O}_{2}$ pode originar células epigeneticamente mais "imaturas", nosso grupo mudou o protocolo de 
derivação para tentar obter melhores modelos para estudo do início da ICX em humanos.

Início da ICX em hESCs derivadas em baixa concentração de $\mathrm{O}_{2}$

Células BR-5 indiferenciadas cultivadas em hipóxia, e diferenciadas cultivadas em normóxia $(20 \%)$ e hipóxia $(5 \%)$, foram submetidas à RT-PCR em tempo real. Contrariamente às nossas expectativas, transcritos de XIST foram detectados nas células BR-5 mesmo indiferenciadas (Figura 14). Além disso, após a diferenciação, os níveis de XIST diminuem nas duas condições ( $5 \%$ e $20 \%$ de $\mathrm{O}_{2}$ ). Amostras de cDNA de BR-1 $(46, \mathrm{XY})$ foram usadas como controle negativo da expressão de XIST.

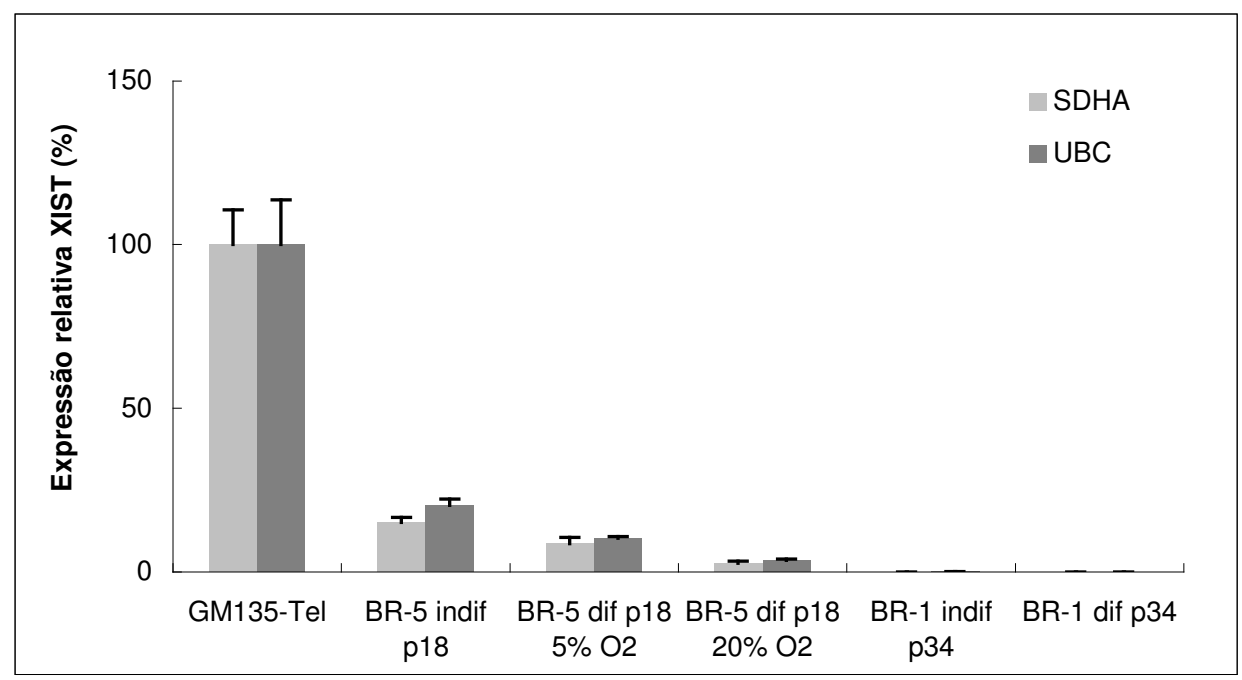

Figura 14: Expressão de XIST em linhagens de hESCs por RT-PCR em tempo real. RTPCR em tempo real realizada com hESCs indiferenciadas (indif) e diferenciadas (dif). BR$5(46, \mathrm{XX})$ foi derivada em $5 \% \mathrm{O}_{2}$ e BR-1 $(46, \mathrm{XY})$ em $20 \% \mathrm{O}_{2}$. A expressão foi comparada à de fibroblastos femininos (GM135-Tel) e normalizada com dois genes, SDHA e UBC. As barras correspondem ao desvio padrão.

Em concordância com os resultados de RT-PCR em tempo real, ensaios de imunocitoquímica revelaram acúmulo de H3K27me3, uma marca característica do Xi, na grande maioria ( 98\%) das células indiferenciadas e diferenciadas (Figura 15). 

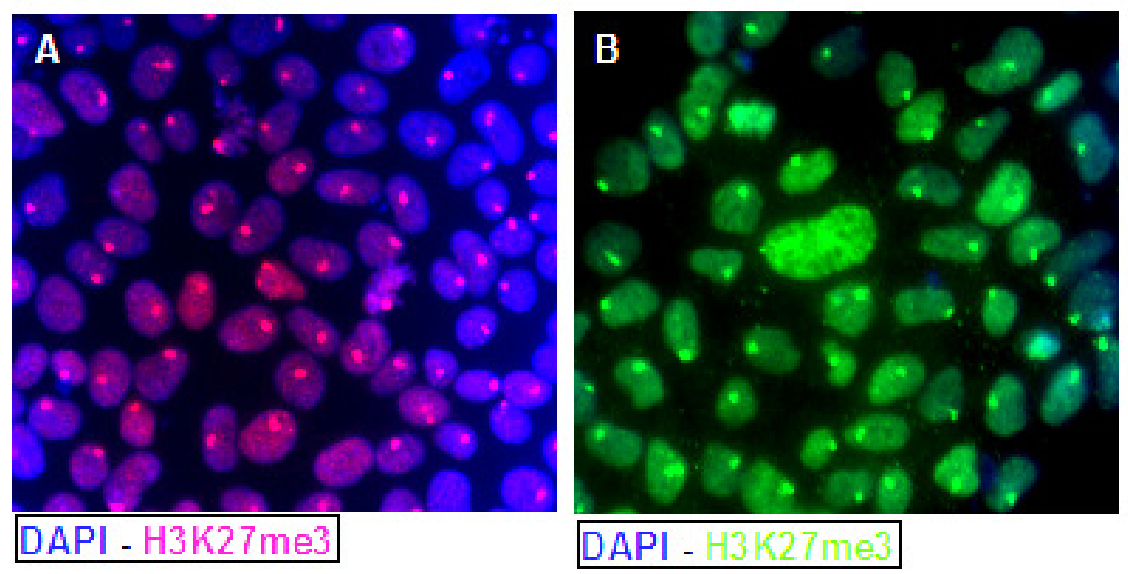

Figura 15: Células BR-5 expressam marcador característico do Xi. Imunocitoquímica com anticorpo anti-H3K27me3, mostrando marcação concentrada no Xi. Em A, células indiferenciadas; em B, células diferenciadas.

\section{Expressão de genes "imprintados"}

Como mais um aspecto epigenético a ser avaliado em linhagens de hESCs, o padrão de expressão de genes "imprintados" foi investigado em hESC indiferenciadas e diferenciadas. Para tanto, foi realizada uma análise em banco de dados do NCBIUniGene - $\quad$ Organized View of the Transcriptome (http://www.ncbi.nlm.nih.gov/unigene/) para sabermos que genes já descritos como “imprintados" são expressos em hESCs ou em corpos embrióides (termos no EST Profile "blastocyst, embryoid bodies"), e ainda possuíssem SNPs descritos na região codificadora; no total, foram selecionados 9 genes (31 cSNPs).

Duas linhagens foram testadas, BR-1 (cultivada em normóxia) e BR-5 (cultivada em hipóxia). Células BR-1 foram genotipadas pela deCODE Scientific Service (www.decodeme.com), enquanto a genotipagem das células BR-5 foi realizada pelo nosso grupo. Os resultados encontram-se na Tabela 4. 
Tabela 4: Genotipagem de genes "imprintados" nas linhagens BR-1 e BR-5.

\begin{tabular}{|c|c|c|c|}
\hline \multirow{2}{*}{ Gene } & \multirow{2}{*}{ SNP } & \multicolumn{2}{|c|}{ gDNA } \\
\hline & & BR-1 & BR-5 \\
\hline \multirow[t]{5}{*}{ ATP10A } & rs 2076741 & - & $\mathrm{G}$ \\
\hline & rs 2076742 & - & $\mathrm{G}$ \\
\hline & rs 2076743 & - & $\mathrm{C} / \mathrm{T}$ \\
\hline & rs 2076744 & $\mathrm{~A} / \mathrm{G}$ & $\mathrm{G}$ \\
\hline & rs 2076745 & $\mathrm{~A}$ & A \\
\hline \multirow[t]{4}{*}{ DLK1 } & rs1802710 & $\mathrm{T}$ & $\mathrm{C} / \mathrm{T}$ \\
\hline & rs 34429112 & - & $\mathrm{C}$ \\
\hline & rs2295660 & $\mathrm{T}$ & $\mathrm{T}$ \\
\hline & rs 1058009 & G & $\mathrm{G}$ \\
\hline \multirow[t]{9}{*}{ H19 } & rs 217727 & $\mathrm{C} / \mathrm{T}$ & $\mathrm{C}$ \\
\hline & rs 10840159 & - & $\mathrm{T}$ \\
\hline & rs 11542726 & - & $\mathrm{C}$ \\
\hline & rs11542724 & - & $\mathrm{T}$ \\
\hline & rs3741216 & - & A \\
\hline & rs 11542723 & - & $\mathrm{G}$ \\
\hline & rs2839703 & - & A \\
\hline & rs2839704 & - & A \\
\hline & rs3741219 & $\mathrm{T}$ & $\mathrm{T}$ \\
\hline$I G F 2$ & rs2585 & $\mathrm{C} / \mathrm{T}$ & $\mathrm{G}$ \\
\hline \multirow[t]{3}{*}{ MAGEL2 } & rs 9785 & $\mathrm{~A} / \mathrm{C}$ & $\mathrm{A}$ \\
\hline & rs10739 & - & A \\
\hline & rs8920 & - & A \\
\hline \multirow[t]{3}{*}{ MEG3 } & rs 1054013 & $\mathrm{G} / \mathrm{A}$ & G/A \\
\hline & rs3742393 & - & G \\
\hline & rs 11160608 & $\mathrm{~A} / \mathrm{C}$ & $\mathrm{C}$ \\
\hline \multirow[t]{2}{*}{ MKRN3 } & rs 36072495 & - & $\mathrm{C}$ \\
\hline & rs2239669 & $\mathrm{C} / \mathrm{T}$ & $\mathrm{C} / \mathrm{T}$ \\
\hline \multirow[t]{3}{*}{ PEG10 } & rs13073 & $\mathrm{C} / \mathrm{T}$ & $\mathrm{C}$ \\
\hline & rs 13226637 & $\mathrm{C}$ & $\mathrm{C}$ \\
\hline & rs1136429 & - & A \\
\hline SNRPN & rs705 & $\mathrm{T}$ & $\mathrm{C} / \mathrm{T}$ \\
\hline
\end{tabular}

Foi observada expressão monoalélica ou preferencial (ATP10A - rs2076744) em todos os genes informativos analisados, tanto em hESCs indiferenciadas como diferenciadas; a única exceção foi o gene $I G F 2$, que apresentou expressão bialélica em células BR-1 diferenciadas. A Figura 16 mostra alguns sequenciamentos representativos referentes à linhagem BR-5, enquanto que os dados completos incluindo uma comparação com os resultados obtidos por outros grupos encontram-se na Tabela 5. 


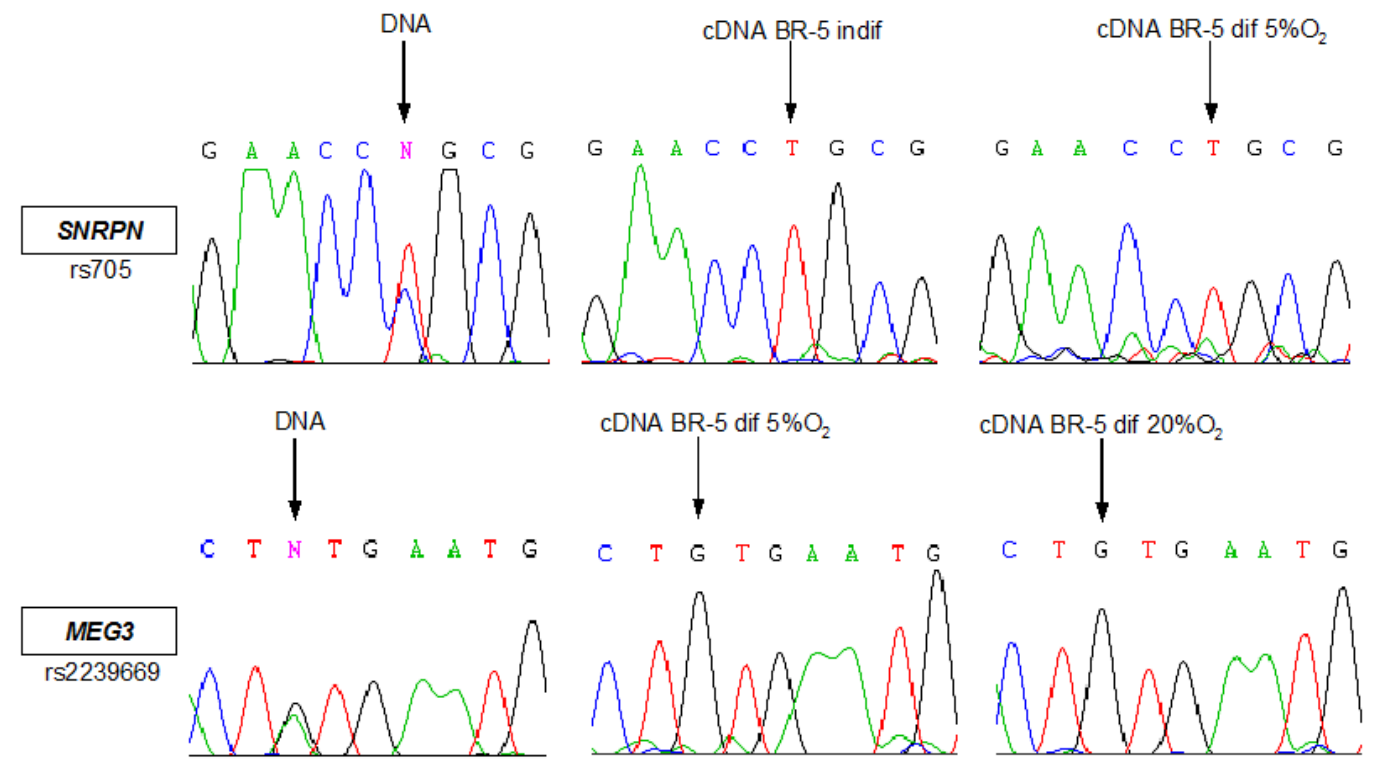

Figura 16: Expressão alelo-específica de genes "imprintados" em células BR-5. Eletroferogramas mostrando genotipagem (DNA) e expressão monoalélica (cDNA) dos genes $S N R P N$ e $M E G 3$ em células indiferenciadas e diferenciadas derivadas sob normóxia $\left(20 \% \mathrm{O}_{2}\right)$ e hipóxia $\left(5 \% \mathrm{O}_{2}\right)$. A existência de um único pico na posição do SNP (setas) informa que o padrão de expressão é "imprintado" nestas células. A identificação de cada SNP é exibida.

Tabela 5: Expressão de genes "imprintados" em hESCs.

\begin{tabular}{|c|c|c|c|c|c|c|c|c|}
\hline \multirow[b]{2}{*}{ Gene } & \multirow{2}{*}{$\begin{array}{l}\text { Identidade } \\
\text { do SNP }\end{array}$} & \multirow[b]{2}{*}{ gDNA } & \multicolumn{6}{|c|}{ cDNA } \\
\hline & & & $\begin{array}{l}\text { BR-1 indif. } \\
20 \% \mathrm{O}_{2}\end{array}$ & $\begin{array}{c}\text { BR-1 Ebs } \\
20 \% \mathrm{O}_{2}\end{array}$ & $\begin{array}{c}\text { BR-5 indif. } \\
5 \% \mathrm{O}_{2}\end{array}$ & $\begin{array}{c}\text { BR-5 EBs } \\
5 \% \mathrm{O}_{2}\end{array}$ & $\begin{array}{c}\text { BR-5 EBs } \\
20 \% \mathrm{O}_{2}\end{array}$ & $\begin{array}{c}\text { Outras } \\
\text { publicações }\end{array}$ \\
\hline \multirow[t]{2}{*}{ ATP10A } & rs 2076743 & $\mathrm{C} / \mathrm{T}$ & $*$ & $*$ & $\mathrm{~T}$ & $\mathrm{~T}$ & - & monoalélica $^{(1)}$ \\
\hline & rs2076744 & $\mathrm{A} / \mathrm{G}$ & $A>g$ & $A>g$ & $*$ & $*$ & $*$ & monoalélica $^{(1)}$ \\
\hline$D L K 1$ & rs1802710 & $\mathrm{C} / \mathrm{T}$ & $*$ & $*$ & - & $\mathrm{T}$ & - & monoalélica $^{(3)}$ \\
\hline$H 19$ & rs217727 & $\mathrm{C} / \mathrm{T}$ & $\mathrm{C}$ & $\mathrm{C}$ & $*$ & * & * & variável $^{(2)}$ \\
\hline$I G F 2$ & rs2585 & $\mathrm{C} / \mathrm{T}$ & - & $\mathrm{C} / \mathrm{T}$ & $*$ & $*$ & $*$ & variável $^{(2)}$ \\
\hline MAGEL2 & rs9785 & $\mathrm{A} / \mathrm{C}$ & $\mathrm{C}$ & - & $*$ & $*$ & * & monoalélica $^{(2)}$ \\
\hline \multirow[t]{2}{*}{ MEG3 } & rs1054013 & $\mathrm{A} / \mathrm{G}$ & A & - & n.e. & G & $\mathrm{G}$ & variável $^{(2)}$ \\
\hline & rs11160608 & $\mathrm{A} / \mathrm{C}$ & $\mathrm{C}$ & - & - & - & - & variável $^{(2)}$ \\
\hline$M K R N 3$ & rs2239669 & $\mathrm{C} / \mathrm{T}$ & n.e. & $\mathrm{T}$ & n.e. & $\mathrm{T}$ & $\mathrm{T}$ & nd \\
\hline PEG10 & rs13073 & $\mathrm{C} / \mathrm{T}$ & $\mathrm{T}$ & $\mathrm{T}$ & $*$ & $*$ & $*$ & monoalélica $^{(2)}$ \\
\hline$S N R P N$ & rs705 & $\mathrm{C} / \mathrm{T}$ & $*$ & $*$ & $\mathrm{~T}$ & $\mathrm{~T}$ & - & monoalélica $^{(2)}$ \\
\hline
\end{tabular}

*SNP não informativo; gDNA: DNA genômico; n.e.: gene não-expresso; EBs: corpos embrióides; - : análise não realizada; expressão preferencial indicada por (>).

${ }^{(1)} \mathrm{Li}$ e colaboradores, 2010

${ }^{(2)}$ Rugg-Gunn e colaboradores, 2007

${ }^{(3)} \mathrm{Kim}$ e colaboradores, 2007

monoalélica: todas as linhagens de hESCs investigadas apresentam expressão monoalélica; variável: a maioria das linhagens de hESCs exibe expressão monoalélica, com exceção de poucas que apresentam expressão bialélica; nd: não determinado. 


\section{4. DISCUSSÃO}

\section{Derivação de linhagens de hESC no Brasil}

Em nosso laboratório, a utilização de dois protocolos diferentes resultou na derivação de quatro linhagens de hESCs: BR-1 e BR-2 foram estabelecidas em mTeSR1 e matrigel, enquanto BR-4 e BR-5 foram derivadas de acordo com o protocolo de derivação II (Tabela 1). O primeiro trabalho que relatou a derivação de linhagens em meio TeSR-1 (Ludwig et al., 2006), o qual deu origem ao mTeSR1 disponível comercialmente, relatou que as células obtidas ou já eram provenientes de embriões aneuplóides (linhagem WA16 - 47,XXY), ou tornaram-se aneuplóides após sete meses em cultura (linhagem WA15 - 46,XY+12). As células BR-1, derivadas em mTeSR1 e matrigel, mantiveram-se estáveis após seis meses de cultivo, como avaliado por cariotipagem convencional e por array-CGH. Vale lembrar que, apesar de o mTeSR1 ser um meio de cultura completamente definido, ele contém proteínas de origem animal, como albumina sérica bovina (BSA), o que poderia dificultar o uso terapêutico das células BR-1. Desde a derivação das primeiras linhagens de hESCs, observaram-se melhorias no protocolo de cultivo das células, que focaram no desenvolvimento de meios de cultura completamente definidos e sem xenocomponentes. Em artigo publicado pelo nosso grupo, foi realizada uma ampla revisão sobre as diferentes metodologias utilizadas na derivação de linhagens de hESC desde 1998 (Anexo 5).

Análises de cariótipo das linhagens BR-4 e BR-5 em passagens mais tardias serão realizadas em breve para sabermos como estas se comportam em tempo prolongado de cultura. Se a euploidia das linhagens for confirmada, concluiremos que aquelas condições de cultura também são adequadas para derivação e propagação de uma linhagem de hESC cariotipicamente normal e estável. 
Várias metodologias foram utilizadas nos experimentos de formação de teratomas, sem sucesso. Uma das causas para o fracasso das tentativas iniciais pode ter sido o fato de que as células usadas para os ensaios eram injetadas na forma single-cell, ou seja, isoladas pela ação de tripsina; acreditamos que muitas células morriam nesse processo, pois elas foram adaptadas a modo de passagem mecânico, e não enzimático. Portanto, optamos também por injetar nos animais não células únicas, mas grumos celulares.

Em 2009, Prokhorova e colaboradores publicaram um artigo relatando que o sucesso de formação de teratomas dependia do local de inoculação, sendo a injeção subcutânea mais eficiente e confortável para os animais. Mais do que isso, o uso de matrigel nas inoculações também aumentava a eficiência de formação de teratomas. Outra interessante constatação foi que hESCs cultivadas sem feeder tinham menor chance de formar teratomas quando injetadas em camundongos (James Thomson, comunicação pessoal). Procuramos levar em consideração todos esses relatos e, com efeito, observamos teratomas em todos os animais C57/B16 Nude injetados com grumos de hESCs indiferenciadas em PBS+matrigel, mantidas anteriormente em cultura sobre camada de feeder murino. $\mathrm{O}$ mesmo protocolo foi empregado para testar a capacidade das BR-4 e BR-5 formarem teratomas, com êxito.

A comparação do perfil HLA de 23 linhagens de hESCs com o das mais de 1 milhão e 300 mil pessoas registradas no REDOME revelou que somente $0,011 \%$ (150/1.300.000) das linhagens são compatíveis com a população brasileira. Os dados sobre a caracterização da linhagem BR-1, bem como uma discussão sobre a importância de se derivar novas linhagens de hESCs de embriões provenientes de populações subrepresentadas foram publicados (Anexo 3). 
Como parte da ISCI-2, foi analisada a estabilidade das hESCs ao longo do tempo de cultura em 127 linhagens, incluindo a BR-1, provenientes de 39 laboratórios diferentes (Anexo 4). Os resultados mostraram que a maioria das linhagens permaneceu cariotipicamente normal. No entanto, foi comum a diversas linhagens o ganho de uma região específica do cromossomo 20 (20q11.21), indicativa de conferir vantagem seletiva às células em cultura. É interessante notar a presença do gene antiapoptótico BCL2L1 nesta região, cuja amplificação poderia promover a sobrevivência das células tanto in vitro como in vivo, sendo o principal candidato a promover vantagem proliferativa nas hESCs. Nossas análises de array-CGH mostraram que não há amplificação desta região nas células BR-1.

\section{Caracterização epigenética das linhagens de hESCs}

Como as mESCs femininas mantém os dois Xa e iniciam a ICX concomitantemente à diferenciação, parecia natural que as hESCs teriam comportamento semelhante e seriam bons modelos do início da ICX em humanos. No entanto, as hESCs não se comportam como as mESCs quando a questão é o estabelecimento da ICX. São poucas as linhagens femininas de hESCs que modelam o início da ICX (estágio pré-ICX) como as mESCs, e uma mesma linhagem pode ainda transitar entre estes possíveis estados de ICX dependendo do tempo e das condições de cultivo (Hoffman et al., 2005; Adewumi et al., 2007; Silva et al., 2008; Shen et al., 2008; Dvash et al., 2010).

Silva e colaboradores (2008) divulgaram que, com relação a ICX, há três classes de linhagens de hESCs: a classe I é definida por células que apresentam um comportamento semelhante às mESC indiferenciadas, com os dois $\mathrm{X}$ ativos (estágio pré-ICX); linhagens pertencentes à classe II encontram-se num estágio pós-ICX, pois 
mesmo células indiferenciadas expressam XIST e apresentam marcadores do Xi; e finalmente a classe III é definida por células com XaXi, mas que perdem e expressão de XIST e a marcação com a H3K27me3 no Xi por razões até o momento desconhecidas.

A variabilidade quanto ao status da ICX entre as linhagens de hESCs pode ser causada pela exposição a um tempo de cultura prolongado ou por razões metodológicas, por não sabermos que condições de cultivo são ótimas para preservação das características epigenéticas das hESCs. Na tentativa de evitar o primeiro problema, adquirimos de outros laboratórios alíquotas de hESCs em passagens iniciais pois, como reportado por alguns trabalhos, ao longo do tempo de cultivo as linhagens de hESC ficam instáveis e propensas a mudanças no seu estado epigenético (Adewumi et al., 2007; Silva et al., 2008; Tanasijevic et al., 2009).

Nossos experimentos de RNA-FISH com hESCs derivadas por Cowan e colaboradores (2004) tiveram resultados inesperados. Silva e colaboradores (2008) incluíram as linhagens HUES-1, HUES-9 e HUES-14 na "classe I" - hESCs indiferenciadas não expressam XIST e diferenciadas expressam (estágio pré-inativação). De acordo com nossas análises, as mesmas linhagens pertenceriam à "classe III", de células que não expressam XIST nem após diferenciação. De fato, Dvash e colaboradores (2010) afirmam que, mesmo em passagens iniciais, as hESCs tendem a iniciar a ICX e logo em seguida a perder marcadores da ICX, como observado pelo presente trabalho. É importante ressaltar que utilizamos passagens um pouco mais iniciais (p18) do que as testadas por Silva e colaboradores (entre p25 e p30).

A única diferença explícita entre as duas investigações foi a condição de cultivo das células. As HUES logo que descongeladas foram cultivadas sobre feeder murino e meio de cultura recomendado pelo grupo que derivou as linhagens. Após uma passagem, no entanto, as células foram adaptadas para condição sem feeder, sendo 
mantidas em matrigel e meio mTeSR1 até a realização dos experimentos (duas semanas, com uma passagem entre elas). Não podemos descartar a hipótese de que os estoques celulares originais já apresentem alguma heterogeneidade de antemão, sendo compostos de linhagens celulares mistas, e que tenha havido seleção de subpopulações com o uso de meios de cultura diferentes.

\section{Derivação em concentração fisiológica de oxigênio}

Lengner e colaboradores (2010) anunciaram que a derivação de linhagens de hESCs em hipóxia (5\% de oxigênio) preserva as hESCs em um estado pré-ICX, além de diminuir a diferenciação espontânea das células. A concentração reduzida de $\mathrm{O}_{2}$ mimetiza a condição fisiológica, por esta razão ela seria benéfica às células (Forristal $e t$ al., 2010). Níveis de 5\% de $\mathrm{O}_{2}$ também aumentam a eficiência de geração de células pluripotentes induzidas (induced pluripotent stem cells - iPSCs) a partir de fibroblastos (Yoshida et al., 2009). Desta forma, por mecanismo ainda não completamente esclarecido, a cultura em hipóxia parece ser mais adequada para o estabelecimento e manutenção de células pluripotentes mais imaturas/primordiais (revisto por Orkin \& Hochedlinger, 2011). Diante destas evidências, as linhagens BR-4 e BR-5 foram derivadas sob hipóxia.

Células BR-5 mesmo indiferenciadas expressam XIST e exibem acúmulo da H3K27me3, características do Xi. Após a diferenciação, entretanto, a expressão de XIST diminui, enquanto que o padrão de marcação da H3K27me3 não se altera, sugerindo que as células BR-5 já foram submetidas à ICX e por alguma razão perderam a expressão de XIST. De fato, Silva e colaboradores (2008) afirmam que pode haver uma perda gradativa das marcas que caracterizam o Xi em hESCs que já inativaram o cromossomo X; ou seja, submetidas à diferentes fatores de estresse (congelamento e 
descongelamento, por exemplo) e a um longo período de cultivo, as células indiferenciadas passariam de um estágio pré-ICX para um pós-ICX, e deste para uma situação em que o Xi perderia suas marcas características (classe III). Baseados nesta classificação, portanto, as células BR-5 encontram-se em transição classe II-classe III.

O status da ICX também está sendo investigado em uma linhagem de hESC feminina, derivada em hipóxia por um grupo do Reino Unido; os resultados de RT-PCR em tempo real mostraram que XIST também é expresso em células indiferenciadas (dados não mostrados). Em conjunto, nossos dados indicam que a derivação em hipóxia não é suficiente para manter os hESCs em um estado pré-ICX. É interessante notar que desde a publicação de Lengner e colaboradores (2010), não houve nenhum outro relato de derivações de hESCs em hipóxia, nem da análise dos mecanismos de ICX nas células por eles estabelecidas.

Outro importante fenômeno epigenético avaliado foi o imprinting genômico. A análise da expressão de genes "imprintados" nas linhagens BR-1 e BR-5 indiferenciadas revelou expressão monoalélica de todos os genes investigados. A Tabela 5 também exibe os resultados obtidos em outras publicações. Com exceção de H19, IGF2 e $M E G 3$, todos os genes avaliados por outros trabalhos apresentavam padrão de expressão "imprintado", e é importante salientar que todas hESCs testadas naquelas publicações foram derivadas em normóxia.

A variação do padrão de expressão de $I G F 2$ encontrada em uma mesma linhagem sugere que a regulação epigenética deste gene é dependente das condições de cultivo, ao invés de ser uma propriedade inerente da própria linhagem (Rugg-Gunn et al. 2010). Por esta razão, a avaliação de genes de expressão variável (IGF2, H19 e MEG3), em especial de $I G F 2$, seria o melhor indicativo para acessar a estabilidade 
epigenética de linhagens de hESCs, pois poderiam indicar condições desfavoráveis de cultivo celular.

Encontramos alguma dificuldade em acessar o padrão de expressão de genes "imprintados" nas hESCs, pois muitas vezes sua expressão era muito baixa. Antes de fazermos esta avaliação de expressão, consultamos bancos de dados para saber quais genes seriam expressos em hESCs, mas essas informações foram inferidas a partir dos dados de expressão em "blastocistos". Li e colaboradores (2010) publicaram que genes como PEG10 e SNRPN são expressos em hESCs indiferenciadas, mas a sua expressão diminui em células diferenciadas; o contrário ocorre com IGF2 e ATP10A. Assim, dados sobre o nível de expressão de genes “imprintados” em hESCs são escassos.

Lengner e colaboradores (2010) acessaram a metilação do DNA das regiões regulatórias de vários genes "imprintados" nas linhagens derivadas sob $5 \% \mathrm{O}_{2}$. Não foram observadas diferenças significativas nos níveis de metilação destes genes entre culturas em $5 \% \mathrm{O}_{2}$ e $20 \% \mathrm{O}_{2}$; apesar de Frost e colaboradores (2011) afirmarem que regiões diferencialmente metiladas (DMRs) associadas aos genes "imprintados" em hESCs possuem perfil de metilação atípico, que não se relaciona à atividade gênica, os resultados de Lengner e colaboradores (2010) sugerem que exista manutenção do sinal de imprinting nas culturas em hipóxia.

Nossos resultados, fundamentados pela análise em linhagens derivadas em hipóxia (BR-5) e normóxia (BR-1), estão de acordo com as publicações, e indicam que o imprinting genômico, ao contrário da ICX, é um fenômeno epigenético mais estável e não influenciado pela concentração de oxigênio. A expressão de genes "imprintados" está sendo investigada pelo nosso laboratório em outra linhagem derivada em hipóxia, BR-4. 
É importante dizer que o estado pré-ICX pode ser alterado por outras perturbações como inibição de proteassomo, tratamento com peróxidos orgânicos e ciclos de descongelamento/congelamento (Lengner et al., 2010). Esses fatores podem ter contribuído para os resultados observados BR-5 derivadas em hipóxia, pois o estado XaXa em hESCs é instável e propenso a iniciar a ICX em resposta ao estresse celular.

O método de passagem das hESCs empregado pode de alguma maneira ter comprometido o processo de ICX nas nossas culturas em hipóxia. As passagens mecânicas exigem que as placas de cultura permaneçam abertas dentro da cabine com fluxo laminar. Ou seja, as células foram expostas a um tempo considerável sob normóxia no momento das passagens. Sabe-se que a expressão de genes induzidos por hipóxia, como por exemplo Hif $2 \alpha$, é muito sensível a pequenas flutuações em $\mathrm{O}_{2}$, e que $H I F 2 \alpha$ ativa a transcrição de $O C T-4$, SOX2 e NANOG (Forristal et al., 2010). De acordo com nossa hipótese, o tempo de duração de uma passagem mecânica poderia ter sido suficiente para provocar degradação de HIF2 $\alpha$ ou outros fatores induzidos por hipóxia envolvidos na regulação de fatores de pluripotência. O fato explicaria a evidência de ICX observada nas células BR-5 indiferenciadas, pois a expressão de XIST é regulada negativamente por OCT-4, SOX2 e NANOG. É importante dizer que a expressão destes últimos é mantida provavelmente por outras vias de sinalização, pois as células BR-5 permanecem indiferenciadas e pluripotentes; porém é possível que uma ligeira diminuição nos níveis de fatores de pluripotência causada pela normóxia temporária seja suficiente para comprometer as hESCs com relação à ICX.

Células pluripotentes e modelos de estudo da ICX

De acordo com o estado epigenético e estágio de desenvolvimento, dois tipos de células-tronco pluripotentes murinas já foram descritos: células-tronco derivadas do 
epiblasto de embriões pós-implantação (mouse epiblast stem cells - mEpiSCs) e célulastronco embrionárias, retiradas da massa celular interna de blastocistos (mouse embryonic stem cells - mESCs).

Em camundongos, a distinção entre esses dois tipos de células é bem conhecida. Tanto mEpiSCs como mESCs expressam os marcadores padrão de pluripotência (Oct4, Nanog, Sox2), e são capazes de diferenciar in vitro e in vivo (teratomas); contudo, as mEpiSCs tem um potencial de diferenciação reduzido por não serem capazes de contribuir para a formação de quimeras (revisto por Orkin \& Hochedlinger, 2011). Estudos recentes revelaram que cada tipo celular utiliza vias de sinalização diferentes para manter a pluripotência. As mESCs são mantidas indiferenciadas via sinalização LIF/STAT3, enquanto que as EpiSCs necessitam de FGF e Activina/Nodal para manter a autorrenovação e a pluripotência. Além disso, as mEpiSCs são refratárias a passagens enzimáticas originando células únicas (Brons et al., 2007).

Há uma hipótese de que as hESCs sejam ortólogas às linhagens de mEpiSCs (Brons et al., 2007; Buecker et al., 2010; Sun et al., 2011). Além de compartilharem as mesmas propriedades de cultivo e manutenção (fatores de crescimento, modo de passagem e morfologia das colônias), linhagens femininas de hESCs e mEpiSCs possuem uma tendência a iniciar a ICX in vitro, ao contrário das mESCs, que se encontram num estágio estável pré-ICX. Além disso, genes que sofrem imprinting geralmente apresentam expressão monoalélica em hESCs e em mEpiSCs (Kim et al., 2007; Sun et al., 2011), enquanto que nas mESCs esses genes exibem expressão bialélica (Sun et al., 2011), ou seja, não se expressam de acordo com o sinal de imprinting adquirido na gametogênese.

Dois grupos produziram células pluripotentes humanas muito semelhantes às mESCs. Buecker e colaboradores (2010) e Hanna e colaboradores (2010) induziram a 
expressão ectópica contínua de fatores de pluripotência (OCT-4, SOX2, e KLF4) em células mantidas em meio de cultura suplementado com LIF, obtendo colônias com perfil de expressão e morfologia muito similares às mESCs (Figura 17).

Hanna e colaboradores (2010) verificaram ainda que, após a reprogramação, ocorre reversão das células para um estado pré-ICX (naïve hIPSC). Ainda não foram avaliados o status da ICX e nem o padrão de expressão de genes "imprintados" na linhagem obtida por Buecker e colaboradores (2010), denominada hLR5 (de LIF humano + expressão constitutiva de 5 fatores de reprogramação). Os dados indicam que diferentes estados de pluripotência podem ser determinados pelas condições de cultivo; no caso específico das hESCs, são requeridas perturbações moleculares adicionais para se reverter a um estado epigenético mais "imaturo" e estável (Hanna et al., 2010). A Figura 17 exibe um quadro comparativo com as principais características de cada tipo de célula pluripotente.

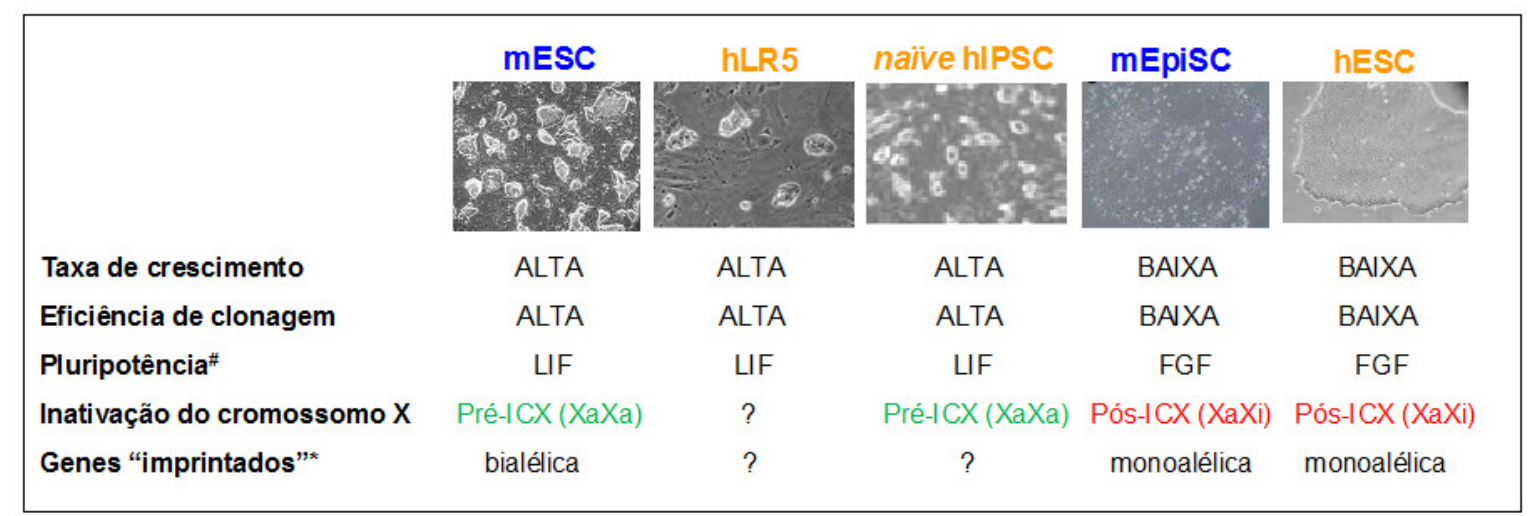

Figura 17: Quadro comparativo com as principais características de células-tronco pluripotentes. As naïve hIPSC e hLR5 compartilham algumas características com as mESCs, consideradas células mais "imaturas". As hESCs e mEpiSCs são consideradas células-tronco mais "derivadas", e possuem tendência iniciar a ICX espontaneamente in vitro. "Fatores utilizados na manutenção da pluripotência; *Expressão de genes "imprintados". Fonte das figuras: nä̈ve hIPSC - Hanna e colaboradores (2010); hLR5 - Buecker e colaboradores (2010); mEpiSC - Brons e colaboradores (2007); mESCs e hESC correspondem às linhagens derivadas em nosso laboratório USP1 e BR-1, respectivamente. 
Assim, a ICX, mas não o imprinting genômico, parece ser um processo comprometido pelas condições de cultivo em hESCs. Nossos resultados sugerem que a cultura das células em hipóxia pode não ser determinante para a ICX, sendo necessária a ativação de outras vias de sinalização para se manter um estado pré-ICX. Como um padrão de ICX aberrante pode refletir instabilidade epigenética global, a presença de XaXa em hESCs é um forte indicativo de cultura saudável e estável (Yang et al., 2011). Assim, pode-se concluir que as atuais condições de cultivo de hESCs não permitem uma análise criteriosa da ICX em humanos. 


\section{Capítulo III}

ManutenÇÃo da ICX EM CÉlulas Humanas: FUNÇÃO DE DNMT1, XIST E SMCHD1 


\section{1. INTRODUÇÃO}

\section{A ICX em células somáticas}

Os eventos que determinam o início do silenciamento do cromossomo $\mathrm{X}$ ocorrem em momentos específicos do desenvolvimento embrionário dos mamíferos eutérios. Como já relatado, acredita-se que um mecanismo complexo sustente o sinal de inativação do cromossomo $\mathrm{X}$ durante o tempo de vida das células femininas e, além disso, que o sistema seja capaz de "copiar" o padrão de ICX e repassá-lo às célulasfilhas após a divisão celular.

O processo de manutenção da ICX depende de uma rede constante de ajustes epigenéticos; neste sentido, a metilação do DNA e as modificações em histonas compõem o núcleo principal de coordenação destes eventos. É lícito, portanto, concluir que proteínas cujas funções são gerar, controlar, e interpretar as alterações na estrutura da cromatina estão intimamente ligadas à manutenção da ICX.

\section{Modificações em histonas}

A estrutura da cromatina dos eucariontes pode ser vista como uma série de camadas organizacionais sobrepostas. A camada mais central seria representada pela presença ou ausência de uma modificação química direta no DNA: a metilação das citosinas. O próximo nível seria representado pela organização do DNA em nucleossomos, uma estrutura que compreende $147 \mathrm{pb}$ de DNA envolto em um octâmero de histonas $\mathrm{H} 2 \mathrm{~A}, \mathrm{H} 2 \mathrm{~B}, \mathrm{H} 3$ e $\mathrm{H} 4$, que podem ser modificadas quimicamente ou substituídas por variantes (revisto por Sakabe \& Nobrega, 2010). O posicionamento dos nucleossomos é resultado direto do conjunto de modificações químicas no DNA e nas histonas; essas modificações que determinam o espaçamento entre os nucleossomos 
representam uma primeira ordem de compactação da cromatina. Camadas adicionais de organização são adicionadas, compostas de proteínas não-histonas, dando conformação tridimensional e caracterizando um estado heterocromático ou eucromático (revisto por Zhou et al., 2011).

Aminoácidos localizados na cauda $\mathrm{N}$-terminal das histonas podem sofrer acetilação, metilação, fosforilação, entre outras dezenas de modificações póstraducionais possíveis; somente alguns tipos de metilação e acetilação foram diretamente correlacionados à transcrição gênica (Barrera \& Ren, 2006). Um “código de histonas" foi proposto para caracterizar o conjunto de modificações em histonas e sua relação com o estado de atividade transcricional (Jenuwein \& Allis, 2001).

Entre as marcas mais conhecidas estão a(s) metilação(ões) da lisina 4 da histona H3 (H3K4me1, H3K4me2, H3K4me3), enriquecidas nas regiões promotoras e em enhancers de genes transcricionalmente ativos, e a trimetilação da lisina 27 da histona H3 (H3K27me3), abundante em regiões regulatórias de genes reprimidos (revisto por Sakabe \& Nobrega, 2010). Já a acetilação de histonas está de um modo geral associada a regiões transcricionalmente ativas do genoma.

Sabe-se que o estado heterocromático é mantido e disseminado pela eucromatina pelo recrutamento de complexos protéicos de histonas desacetilases (HDACs) e metiltransferases (por exemplo, as proteínas da classe Polycomb) que catalizam a metilação das lisinas 9 e 27 da histona H3 (revisto por Sakabe \& Nobrega, 2010). De fato, durante o estabelecimento da ICX, o primeiro evento observado após o RNA de Xist recobrir in cis o Xi é o enriquecimento deste cromossomo com a H3K27me3 (revisto por Nora \& Heard, 2011). Acredita-se que presença do RNA de Xist no futuro Xi recruta proteínas que modificam histonas, como as proteínas do complexo Polycomb PRC1 e PRC2. 
O Xi é enriquecido em modificações e variantes de histonas características de regiões silenciadas, como H3K9me2, H3K9me3, H4K20me1, H2AK119Ub (ubiquitinação da lisina 119 da histona H2A) e da variante macroH2A.1 (revisto por Chow \& Heard, 2009). Entretanto, não está esclarecido como essas modificações em histonas são promovidas, e qual é função do acúmulo de Xist neste processo.

\section{Metilação do DNA}

Desde a década de 70 sabe-se que existe relação entre a metilação do DNA de regiões próximas aos genes e sua atividade (Holliday \& Pugh, 1975). Hoje sabemos que a metilação concentrada em regiões promotoras está diretamente relacionada com a atividade transcricional, sendo interpretada por fatores de transcrição no sentido de impossibilitar a transcrição gênica. A metilação exerce um papel fundamental no controle de expressão gênica em vários processos biológicos, durante a diferenciação celular e no silenciamento de sequências repetitivas, prevenindo instabilidade genômica (Walsh et al., 1998; revisto por Hermann et al., 2004). Além disso, o controle da expressão de genes reprimidos no Xi e de genes "imprintados" inclui também a metilação de suas regiões regulatórias. A metilação das ilhas $\mathrm{CpG}$ (regiões genômicas ricas em dinucleotídeos $\mathrm{CpG}$ ) nas regiões promotoras de genes submetidos à $\mathrm{ICX}$ é um evento tardio dentre as modificações necessárias para a heterocromatinização do Xi (revisto por Chow \& Heard, 2009).

Vários estudos compararam o grau de metilação entre o cromossomo $\mathrm{X}$ de machos e fêmeas. Weber e colaboradores (2005) verificaram que, apesar de as ilhas CpG próximas a promotores constitutivamente ativos estarem hipermetiladas no $\mathrm{Xi}$, os níveis globais de metilação no X eram menores em fêmeas do que em machos, especialmente em regiões com poucos genes. Além disso, o Xa possui um tipo de 
metilação diferente, situada dentro das sequências gênicas (Hellmann \& Chess, 2007); este tipo de metilação já foi observado em marsupiais e plantas, mas sua função não é compreendida, e pode indicar um possível papel da metilação fora das regiões regulatórias dos genes (revisto por Chow \& Heard, 2009).

As proteínas responsáveis pela adição de um grupo metil às citosinas são denominadas DNA-metiltrasferases (DNMTs). Até o momento, foram descritas cinco proteínas pertencentes a esta família, e especificamente as de conhecida atuação na metilação de citosinas no DNA são DNMT1, DNMT3A e DNMT3B. Enquanto as DNMT3A e DNMT3B são metiltransferases de novo, capazes de estabelecer o padrão de metilação durante o desenvolvimento, a DNMT1 tem preferência por DNA hemimetilado, e é a metiltransferase responsável por repassar fielmente às células-filhas o padrão de metilação, sendo esta a principal metiltransferase de manutenção conhecida (revisto por Bestor, 2000).

Li e colaboradores (1992) descreveram que mutação em Dnmt1 (com redução de mais de $70 \%$ das citosinas metiladas) é letal em camundongos; níveis alterados de metilação global no DNA decorrentes da deleção de Dnmt1 provocaram expressão bialélica de Igf2, um gene que sofre imprinting (Li et al., 1993), e expressão aberrante de Xist em células somáticas masculinas (Beard et al., 1995).

Em humanos, o papel de DNMT1 é muito controverso. Células tumorais

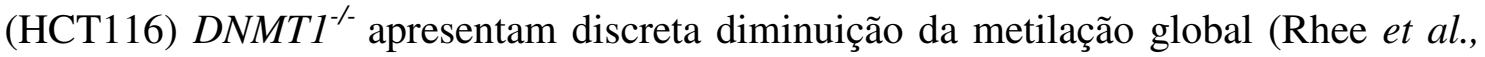
2000); já o duplo-nocaute $D N M T 1^{{ }^{-}} D_{N M T 3 B^{-/}}$(células DKO) possui $95 \%$ de redução da metilação global; de acordo com estes trabalhos, DNMT1 e DNMT3B agem em conjunto e têm funções sobrepostas em humanos (Rhee et al., 2002).

No entanto, os trabalhos de Rhee e colaboradores foram questionados por Egger e colaboradores (2006), uma vez que as células $D N M T 1^{-/}$ainda apresentavam uma 
hipoforma de DNMT1 com o domínio catalítico conservado que poderia mascarar o fenótipo real de um nocaute de DNMT1. No ano seguinte, outro nocaute de DNMT1 em células HCT116 foi gerado (Chen et al., 2007), e de fato as células entraram em apoptose, confirmando a inviabilidade de um nocaute de DNMT1 em células humanas.

Em nosso laboratório, as células nocaute para as diferentes DNMTs foram investigadas quanto à expressão do gene XIST; contrariamente ao que foi visto em camundongos, o estado reprimido de XIST foi mantido (Vasques et al., 2005), sugerindo que existem diferenças quanto a função de Dnmt1/DNMT1 na regulação de Xist entre camundongos e humanos.

O papel de XIST

A função do RNA de Xist durante o início da ICX é recrutar as futuras modificações na estrutura da cromatina que culminam na inativação de todo o cromossomo X. No entanto, a função de Xist na manutenção da ICX é ainda debatida.

Alguns trabalhos assumem que a janela temporal de atuação de Xist parece ser restrita ao início da ICX, uma vez que a eliminação do gene em células somáticas humanas não causa reativação de genes submetidos à ICX (Brown \& Willard, 1994), nem altera o padrão de replicação tardia e o estado silenciado do cromossomo isodiscêntrico derivado do Xi em células leucêmicas (Rack et al., 1994). Esses resultados levaram a conclusão que, uma vez estabelecida a ICX, Xist não seria mais necessário.

Outros autores, no entanto, afirmaram que a ausência de Xist pode desencadear ativação do X previamente inativado. A deleção de Xist em células murinas causou reexpressão de um gene ligado ao X (Hprt); além disso, os autores sugerem que ocorra 
uma atuação sinergística entre a presença do RNA de Xist, a metilação do DNA e do complexo de histonas desacetilases na manutenção da ICX em camundongos (Csankovszki et al., 2001). Em trabalho posterior, Hall e colaboradores (2002) observaram que ocorre inativação cromossômica em células somáticas humanas transfectadas com vetores indutíveis para expressão de XIST; o silenciamento pode ser revertido com a interrupção da indução. Sustentando este raciocínio, a expressão contínua de Xist/XIST durante toda a vida útil das células somáticas sugere que, de alguma maneira, Xist/XIST participa também da manutenção da ICX.

O papel de SMCHDI

Em trabalho recente, Blewitt e colaboradores (2008) identificaram um novo participante da manutenção da ICX: Smchd1 (do inglês structural maintenance of chromosomes hinge domain), uma proteína muito conservada entre anfíbios, aves e mamíferos eutérios. Por possuir domínio SMC na porção C-terminal, ela é incluída na classe das coesinas e condensinas, proteínas importantes na segregação cromossômica durante a divisão, recombinação e reparo do DNA (Anderson et al., 2002; Kanno et al., 2008).

Mutação em homozigose de Smchdl é letal em fêmeas de camundongo, em período tardio da gestação; a análise das células mutadas revelou hipometilação no Xi e aumento de expressão de genes submetidos à ICX (Blewitt et al., 2008). No entanto, não houve alteração nos níveis do transcrito de Xist e nem no padrão de localização de H3K27me3, o que sugere que o início da ICX não foi comprometido. Fato muito interessante é que as proteínas SMCs participam da compensação de dose em $C$. elegans, promovendo a diminuição de expressão dos dois cromossomos $\mathrm{X}$ nos 
hermafroditas XX (Chuang et al., 1994). Em humanos, ainda resta saber qual é a função de SMCHD1 na ICX.

Modelos de estudo da manutenção da ICX em humanos

A maioria dos trabalhos que tiveram como objetivo explorar a questão sobre a manutenção da ICX em humanos utilizou como modelo de estudo in vitro células transformadas, de fácil obtenção e cultivo, ou células somáticas híbridas, resultado da fusão de núcleos de células humanas e de roedores. As células híbridas têm a propriedade de eliminar cromossomos ao longo das divisões celulares; células resultantes que mantêm o cromossomo Xi humano e eliminam o Xa são selecionadas, uma vez que nelas é possível observar mais claramente a reativação de alelos reprimidos no $\mathrm{Xi}$.

A hipótese testada partia da premissa que, se uma determinada perturbação causasse a reativação de um gene do $\mathrm{Xi}$, o fenômeno perturbador teria função na manutenção da ICX. Apesar de serem modelos consagrados, células híbridas ou transformadas não são ideais para se estudar fenômenos epigenéticos, pois o contexto celular artificial e/ou aberrante atrapalha a interpretação dos resultados.

Por esta razão, em nosso laboratório procuramos investigar a manutenção da ICX tendo como modelo células somáticas humanas não-transformadas, que melhor representam in vitro o contexto epigenético mais próximo do encontrado naturalmente. As células selecionadas são fibroblastos obtidos de uma mulher portadora da Síndrome de Lesch-Nyhan, heterozigota para uma mutação no gene HPRT (hipoxantina guanina fosforibosiltransferase 1), ligado ao X e submetido à ICX. A enzima participa do metabolismo das purinas e, por esta característica, é possível selecionar sublinhagens 
celulares que possuem desvio completo de inativação, através da exposição destas células a diferentes meios de cultivo (Migeon, 1970; Vasques \& Pereira, 2001).

Com a identificação de um grande número de polimorfismos de base única (SNPs) no cromossomo X (Ross et al., 2005), foi possível determinar o perfil de inativação de cada gene desse cromossomo (Carrel \& Willard, 2005). A distinção entre os alelos, possibilitada pela existência de SNPs na região codificadora dos genes, permitiu a geração de um painel de atividade de genes ligados ao $\mathrm{X}$ neste modelo celular com ICX desviada (Stabellini, 2008). Assim, distúrbios na manutenção da ICX podem ser identificados, uma vez que mudanças no padrão de expressão aleloespecífica dos genes ligados ao $\mathrm{X}$ denunciam alterações no processo. Foi objetivo deste trabalho estudar a função de XIST, DNMT1 e SMCHD1 na manutenção da ICX humana, por interferência de RNA (RNAi) em um modelo celular epigeneticamente mais próximo do natural. 


\section{$\underline{\text { Modelo celular }}$}

Para estudar a manutenção da ICX em células somáticas humanas, nosso modelo foi a linhagem celular GM135-Tel. Essa linhagem foi estabelecida de fibroblastos provenientes de uma mulher portadora da Síndrome de Lesch-Nyhan, que possui uma mutação no gene HPRT (da enzima hipoxantina guanina foforibosiltransferase), localizado no cromossomo X (GM00135 - Coriell Institute). Em nosso laboratório, as células foram cultivadas em meio HAT (hipoxantina, aminopterina, timidina), e uma sublinhagem com desvio de ICX foi selecionada (Vasques \& Pereira, 2001), onde o cromossomo $\mathrm{X}$ ativo possui o alelo normal de $H P R T$.

Para possibilitar o cultivo a longo prazo, as células com desvio de ICX foram imortalizadas com a restituição de atividade da telomerase (Vasques, 2003), sendo a partir de então denominadas GM135-Tel. Depois de selecionar as células com meio HAT, as células foram mantidas em meio para fibroblastos composto de $15 \%$ SFB (Cultilab), $50 \mathrm{U} / \mathrm{mL}$ de penicilina e $50 \mathrm{mg} / \mathrm{mL}$ de estreptomicina (Invitrogen), $2 \mathrm{mM}$ Glutamax-I (Invitrogen), 1\% aminoácidos não-essenciais (Sigma) em meio DMEM com alta concentração de glicose (DMEM high glucose - Invitrogen).

\section{$\underline{\text { Práticas gerais de cultivo }}$}

III. 2.1. Descongelamento das células

Alíquotas criopreservadas das células foram descongeladas por dois minutos em banho-maria a $37{ }^{\circ} \mathrm{C}$. Ao descongelado adicionaram-se $4 \mathrm{~mL}$ de DMEM com alta 
concentração de glicose (DMEM high glucose) ou meio de cultura completo de fibroblastos. As células foram centrifugadas à temperatura ambiente por 5 minutos a $1000 \mathrm{rpm}$. O meio foi sugado e ao precipitado foi acrescentado meio de cultura, em volume dependente da quantidade de células. As células foram mantidas a $37^{\circ} \mathrm{C} \mathrm{em}$ incubadora com $5 \% \mathrm{CO}_{2}$.

III. 2.2. Subcultivo celular

As células foram lavadas com PBS e dissociadas das placas com 0,25\% tripsinaEDTA (Invitrogen) por 5 minutos na incubadora. A reação foi interrompida com meio de cultura completo, no qual as células foram ressuspendidas e centrifugadas a 1000 rpm por 5 minutos. Após a centrifugação, o meio foi sugado e às células foi acrescentado meio de cultura completo. Os fibroblastos foram ressuspendidos e divididos em placas de cultura conforme o número de células ou o interesse do experimento seguinte.

III. 2.3. Congelamento das células

Para congelar as células, estas foram dissociadas das placas de cultura como descrito no item III. 2.2., e ressuspendidas em meio de congelamento composto de $10 \%$ DMSO, 20\% SFB e DMEM com alta concentração de glicose (DMEM high glucose). As alíquotas foram mantidas por até 72 horas a $-80{ }^{\circ} \mathrm{C}$ e depois armazenadas indefinidamente em nitrogênio líquido.

III. 2.4. Curva de sobrevivência à puromicina 
Cerca de $10^{5}$ fibroblastos GM135-Tel foram plaqueados em poços de placa de 6 poços. No dia seguinte, cada poço com células recebeu meio fresco contendo cinco concentrações diferentes de puromicina: $1 \mu \mathrm{g} / \mathrm{ml}, 750 \mathrm{ng} / \mathrm{mL}, 500 \mathrm{ng} / \mathrm{mL}, 250 \mathrm{ng} / \mathrm{mL}$, $100 \mathrm{ng} / \mathrm{mL}$. Um dos poços foi mantido como controle sem adição de puromicina.

Os fibroblastos permaneceram em cultura por uma semana; por análise visual, foi definida a concentração de puromicina apropriada $(500 \mathrm{ng} / \mathrm{mL})$ para seleção das células após transdução.

\section{$\underline{\text { Silenciamento por RNAi }}$}

Foram adquiridos da empresa OpenBiosystems dois vetores lentivirais para silenciamento do gene XIST humano, sendo um indutível por doxiciclina/tetraciclina (tet-on - pTRIPZ) e outro não indutível (pGIPZ), cada um contendo sequências-alvo diferentes para produção de shRNA (short hairpin RNAs). O vetor pTRIPZ combina as vantagens da técnica de shRNA com o uso de promotor induzido por doxiciclina, uma droga pertencente à família das tetraciclinas. Assim, há um controle de quando as células em cultura começarão a expressar os vetores de silenciamento gênico. Todos os vetores adquiridos já possuíam a sequência para produção dos shRNAs.

Foram adquiridos também da empresa OpenBiosystems mais dois vetores não indutíveis, cada um contendo uma sequência-alvo para silenciamento de DNMT1. Estudos recentes realizados em camundongos apontam para uma participação da proteína SMCHD1 na manutenção do estado inativo do cromossomo X (Blewitt et al., 2008). Assim, para avaliarmos sua função em células humanas, também foi obtido um vetor indutível para produção de shRNA contra este gene. 
A Tabela 6 resume algumas características dos plasmídeos e a sequência-alvo para knockdown de cada gene.

Tabela 6: Genes avaliados e plasmídeos utilizados neste estudo.

\begin{tabular}{||c|c|c|c|c|c||}
\hline \hline Gene & Vetor & Expressão & $\begin{array}{c}\text { Número de } \\
\text { acesso* }\end{array}$ & $\begin{array}{c}\text { Código da } \\
\text { Empresa }^{\#}\end{array}$ & Sequência-alvo \\
\hline$X I S T$ - alvo 1 & pGIPZ & GFP & NR_001564.1 & V2LHS_92226 & CAGGCGTTGTCATATGTAT \\
\hline$X I S T$ - alvo 2 & pTRIPZ & RFP indutível & NR_001564.1 & V2THS_92229 & CCTGTTATGTGTGTGATTA \\
\hline$D N M T 1$ - alvo 1 & pGIPZ & GFP & NM_001130823.1 & V2LHS_113506 & CCTGCAAGGACATGGTTAA \\
\hline DNMT1 - alvo 2 & pGIPZ & GFP & NM_001130823.1 & V2LHS_113503 & GAGTCTGGCTTTGAGAGTT \\
\hline SMCHD1 & pTRIPZ & RFP indutível & NM_015295.2 & V2THS_140545 & CCATTGGTCTCAGTAAGAA \\
\hline
\end{tabular}

* sequência do transcrito depositada no $N C B I$

\# Número de referência no catálogo da OpenBiosystems

GFP: green fluorescent protein; RFP: red fluorescent protein

III. 2.5. Obtenção dos plasmídeos em média escala - midiprep

Os vetores foram adquiridos em alíquotas de bactérias previamente transformadas. Assim, bactérias foram estriadas em placas com $20 \mathrm{~mL}$ de meio LB/ágar contendo $100 \mu \mathrm{g} / \mathrm{mL}$ de ampicilina, e incubadas por 16 horas em estufa a $37{ }^{\circ} \mathrm{C}$. Colônias isoladas foram pré-inoculadas em $3 \mathrm{~mL}$ de meio LB líquido com ampicilina e incubadas a $37{ }^{\circ} \mathrm{C}$ durante 8 horas sob agitação constante.

Cem microlitros do pré-inóculo foram inoculados em $25 \mathrm{~mL}$ de meio $\mathrm{LB}$ contendo $100 \mu \mathrm{g} / \mathrm{mL}$ de ampicilina e incubado durante 14-16 horas sob agitação a 37 ${ }^{\circ} \mathrm{C}$. A partir dessa cultura, a obtenção de DNA plasmideal em média escala foi realizada com a utilização do Plasmid Midi kit (Qiagen), segundo instruções do fabricante. Em seguida, o plasmídeo contendo o DNA de interesse foi quantificado pelo espectrofotômetro e uma alíquota foi digerida com a enzima de restrição SalI (vetor indutível - pTRIPZ) e SacII (vetor não indutível - pGIPZ) -Amersham Pharmacia-, 
conforme orientações do protocolo do fabricante, para confirmar sua integridade. Os produtos da digestão foram visualizados em gel de agarose $1 \%$ corado com brometo de etídeo $0,5 \mu \mathrm{g} / \mathrm{mL}$. As construções purificadas foram então transfectadas em células HEK-293T, produtoras dos lentivírus.

III. 2.6. Produção dos lentivírus em células HEK-293T

O procedimento para produção lentiviral foi feito em colaboração com o grupo do Prof. Dimas Tadeu Covas, do Hemocentro de Ribeirão Preto, sob a supervisão da Dra. Virgínia Picanço.

Células HEK-293T foram cultivadas em meio DMEM, suplementado com 10\% de SFB (Cultilab), $2 \mathrm{mM}$ de L-glutamina (Invitrogen) e $50 \mathrm{U} / \mathrm{mL}$ de penicilina e 50 $\mathrm{mg} / \mathrm{mL}$ de estreptomicina (Invitrogen), e mantidos em estufa a $37^{\circ} \mathrm{C}$ e $5 \%$ de $\mathrm{CO}_{2}$.

Após atingirem confluência de $80 \%$, as células foram lavadas com PBS e dissociadas das garrafas de cultivo por tratamento de 5 minutos com $0,25 \%$ tripsinaEDTA (Invitrogen) na incubadora. A digestão foi interrompida com a adição de meio de cultura e as células foram transferidas para um tubo cônico de $15 \mathrm{~mL}$, de onde uma alíquota foi retirada para contagem das células em câmara de Neubauer (Knittel Gläser). Aproximadamente $2 \times 10^{6}$ células foram semeadas em placas de $10 \mathrm{~cm}^{2}$ e mantidas na incubadora.

No dia seguinte, acrescentou-se às células $9,5 \mathrm{~mL}$ de meio completo sem antibiótico. Para transfecção de cada construção foram feitas duas misturas, uma plasmideal, contendo somente os vetores envolvidos na produção do vírus e outra contendo meio DMEM e Fugene (Roche), perfazendo um total (vetores+DMEM+fugene) de $500 \mu \mathrm{L}$. Na mistura plasmideal foram acrescentados $15 \mu \mathrm{g}$ de DNA plasmideal, $10 \mu \mathrm{g}$ do vetor para produção do capsídeo e $5 \mu \mathrm{g}$ do vetor para 
produção do envelope lentiviral (VSV-G). Estes plasmídeos foram gentilmente cedidos pela Dra. Virgínia Picanço.

Em outro tubo, $90 \mu \mathrm{L}$ de Fugene (Roche) foram diluídos em DMEM e incubados por 5 minutos a temperatura ambiente. Após esse tempo, esta mistura e a solução plasmideal foram reunidas em um só tubo, que após 15 minutos de incubação a temperatura ambiente foram transferidas para as células. Após seis horas, o meio de transfecção foi retirado e substituído por $6 \mathrm{~mL}$ de meio de cultura com $10 \%$ SFB. As células foram mantidas por 48 horas na estufa, e em seguida o meio contendo as partículas lentivirais produzidas foi coletado e filtrado em filtros de $0,45 \mu \mathrm{m}$. Uma parte foi transferida para os fibroblastos imediatamente e o restante foi congelado a $-80^{\circ} \mathrm{C}$.

\section{2.7. Transdução em fibroblastos GM135-Tel}

Aproximadamente $2 \times 10^{4}$ fibroblastos humanos da linhagem GM135-Tel foram cultivados em placa de 24 poços. No dia seguinte, foram preparadas misturas contendo sobrenadante viral coletado e $8 \mu \mathrm{g} / \mathrm{mL}$ polibreno. A mistura foi incubada por 5 minutos a temperatura ambiente. Em seguida, o meio de cultura dos fibroblastos foi retirado, 150 $\mu \mathrm{L}$ de DMEM puro foram acrescentados à mistura polibreno mais sobrenadante viral e estes transferidos para as células. Os vírus permaneceram em contato com as células por 5 horas, e depois deste tempo foi acrescentado $1 \mathrm{~mL}$ de meio de cultura completo aos fibroblastos.

Passadas 48 horas, o meio de cultura foi substituído por meio contendo 500 $\eta \mathrm{g} / \mathrm{mL}$ de puromicina (ver item III.2.4.) para seleção das células que continham o plasmídeo de interesse. A seleção foi mantida por 10 dias, sendo que o meio de seleção era trocado a cada dois dias. Eventualmente as células foram repicadas com tripsina para placas com área maior. 


\section{2.8. Indução da expressão com doxiciclina}

Os fibroblastos transduzidos com vetores lentivirais pTRIPZ foram incubados com meio contendo $500 \mathrm{ng} / \mathrm{mL}$ de doxiciclina (Clontech), após o período de 10 dias de seleção. A indução da expressão com meio contendo doxiciclina durou 3 dias (especificado pelo protocolo dos fabricantes dos vetores), e após esse período as células foram coletadas para análises de metilação global, expressão gênica e proteica.

Durante os dias de indução, as células foram observadas diariamente em microscópio de fluorescência invertido para investigação da presença de células RFP+; da mesma maneira, os fibroblastos transduzidos com pGIPZ eram observados em microscópio de fluorescência para a visualização de células GFP+.

\section{2.9. Tratamento com ácido valproico (VPA)}

Após transdução, células que receberam vetores para produção de shRNA para DNMT1 foram também tratadas com ácido valproico (VPA), um potente inibidor do complexo de histonas desacetilases (HDAC). Em outras palavras, o uso de VPA pode aumentar os níveis de histonas acetiladas.

Em seu trabalho de mestrado, a aluna Érica Sara Souza de Araújo definiu uma concentração de VPA adequada para aumentar os níveis de acetilação da histona H4 sem comprometer a viabilidade de fibroblastos GM135-Tel (Araújo, 2012).

Assim, $5 \mathrm{mM}$ de VPA foram adicionados aos fibroblastos com níveis diminuídos de DNMT1 e controle; o tratamento durou 6 horas. Após esse tempo, as células foram retiradas das placas de cultivo por dissociação com $0,25 \%$ tripsina-EDTA, lavadas com PBS e congeladas a $-80{ }^{\circ} \mathrm{C}$ para posterior coleta de DNA, RNA e proteínas. 
III. 2.10. Tempo de dobramento das células

O tempo de dobramento das sublinhagens celulares foi determinado a partir do plaqueamento de $8 \times 10^{3}$ células por poço em placa de 24 poços. Para cada dia de contagem, células de três poços distintos eram dissociadas com 0,25\% tripsina-EDTA, incubadas com azul de tripan (Invitrogen) diluído 1:1 por cinco minutos, e contadas em câmara de Neubauer (Knittel Gläser).

Para os fibroblastos transduzidos com vetores indutíveis por doxiciclina, um dia após plaqueamento 12 poços com células receberam $500 \mathrm{ng} / \mathrm{mL}$ de doxiciclina e 12 , não. A cada dia, durante três dias consecutivos (tempo de exposição das células à droga), as células com e sem doxiciclina foram contadas.

As células transduzidas com vetores para silenciamento de DNMT1 foram mantidas por sete dias e, a cada dois dias, contadas. Os outros poços foram utilizados como controle e, portanto, mantidos, com troca de meio a cada dois dias.

O tempo de dobramento foi determinado por plotagem em gráfico, onde cada ponto foi determinado pela média do número de células presentes em três poços.

\section{Análises de expressão gênica após silenciamento por RNAi}

III. 2.11. Extração de ácidos nucleicos

O DNA das células foi extraído com o kit FlexiGene (Qiagen), conforme instruções do fabricante, quantificado e guardado a $-20{ }^{\circ} \mathrm{C}$. O RNA total foi obtido seguindo as instruções do kit RNeasy Mini (Qiagen), quantificado e estocado em freezer $-80{ }^{\circ} \mathrm{C}$. 


\section{2.12. Síntese de cDNA}

Dez microgramas do RNA total foram tratados com a enzima Turbo DNA-free (Ambion); após tratamento, o RNA foi requantificado e $2 \mu \mathrm{g}$ foram utilizados para síntese de cDNA por transcrição reversa, realizada com o kit Superscript III (Invitrogen), utilizando $150 \mathrm{ng}$ de iniciadores randômicos, conforme orientações do fabricante. Como controle dos tratamentos para eliminação de DNA genômico, amostras de RNA tratado onde não foi adicionada transcriptase reversa (RT-) também foram submetidas às RT-PCRs.

\section{2.13. Expressão dos genes silenciados}

Para confirmar o silenciamento dos genes, a expressão de cada um deles foi avaliada por RT-PCR em tempo real. O cDNA dos fibroblastos transduzidos foi sintetizado a partir do RNA tratado para eliminação de DNA genômico, segundo protocolos descritos nos itens III.2.9 e III.2.10.

Vinte e cinco nanogramas de cDNA foram amplificados usando 1X TaqMan Universal PCR Master Mix ou 1X SYBR Green PCR Master Mix (Applied Biosystems). Em todas as amplificações realizadas, foram utilizados os parâmetros universais de ciclagem $\left[50^{\circ} \mathrm{C} / 2 \mathrm{~min} ; 95^{\circ} \mathrm{C} / 10 \mathrm{~min} ; 40\right.$ ciclos $\left.\left(95^{\circ} \mathrm{C} / 15 \mathrm{~s} ; 60^{\circ} \mathrm{C} / 1 \mathrm{~min}\right)\right]$, e ao final de cada reação foram realizadas curvas de dissociação para controle de eventuais contaminações.

Para quantificar a expressão do gene XIST, foi obtido da Applied Biosystems o ensaio para sistema Taqman (ID Hs01079824_m1, sonda FAM/MGB). A padronização deste ensaio foi feita pela Dra. Raquel Stabellini durante seu doutoramento. No caso dos genes-alvo DNMT1 e SMCHD1, e os utilizados para normalização (controle endógeno), pares de iniciadores foram desenhados por alguns integrantes do nosso grupo com o 
auxílio da ferramenta PrimerExpress (Applied Biosystems), ou as sequências foram retiradas de publicações (Vandesompele et al., 2002; Wikman et al., 2002; Zhao et al., 2003); para serem utilizados em ensaios com SYBR Green Master Mix. Diversos genes foram testados como normalizadores das reações. Os mais estáveis de acordo com o software geNorm VBA para Excel (Vandesompele et al., 2002) foram mantidos, e a expressão dos genes-alvo foi comparada entre as amostras de acordo com orientações do aplicativo. Os genes e a sequência de seus iniciadores são:

DNMT1 F - 5' TGAAGGTGGTGTTAATGGCAAA 3'

DNMT1 R - 5'CGGCAAATGAGGTGCTGAA 3'

SMCHD1 F - 5' CCACAGGACGGTGTACTTGTT 3'

SMCHD1 R - 5'GGTGAAATGCCAAGTGTCTG 3'

HMBS F - 5' CTGGAAGGAGGCTGCAGTGT 3'

HMBS R - 5' TACAGTTGCCCATCCTTCATAGC 3'

TOP1 F - 5' TCCGGAACCAGTATCGAGAAGA 3'

TOP1 R - 5' CCTCCTTTTCATTGCCTGCTC 3'

YWHAZ F - 5' AAACCAACAGCGACTTGGAAGCAC 3'

YWHAZ R - 5' GTGCTTCCAAGTCGCTGTTGGTTT 3'

B2M F - 5' CACCCCCACTGAAAAAGATG 3'

$B 2 M$ R - 5' ATATTAAAAAGCAAGCAAGCAGA 3'

SDHA F - 5' TGGGAACAAGAGGGCATCTG 3'

SDHA R - 5' CCACCACTGGATCAAATTCATG 3'

TBP F - 5' TTCGGAGAGTTCTGGGATTGTA 3'

TBP R - 5' TGGACTGTTCTTCACTCTTGGC 3'

UBC F - 5' ATTTGGGTCGCGGTTCTTG 3'

UBC R - 5' TGCCTTGACATTCTCGATGGT 3'

GAPDH F - 5' CTCTCTGCTCCTCCTGTTCGAC 3'

GAPDH R - 5' TGAGCGATGTGGCTCGGCT 3' 


\section{2.14. Amplificação por RT-PCR}

A expressão alelo-específica de genes submetido à ICX e "imprintados" foi verificada por amplificação e sequenciamento direto de uma região contendo um polimorfismo de base única na sequência codificadora do gene (single nucleotide polymorphisms - cSNPs). Em trabalho anterior, Stabellini (2008) definiu uma lista de genes presentes no $\mathrm{X}$ para os quais a linhagem GM135-Tel é informativa, ou seja, heterozigota na posição de determinado cSNP. Para os genes $M A O A$ e $M A O B$, novos iniciadores foram desenhados pelo aluno de mestrado do nosso laboratório Fernando Sábio, com o objetivo de amplificar regiões contendo outros cSNPs; a genotipagem destes SNPs foi realizada neste trabalho. Ao todo, 11 genes e 16 SNPs foram analisados; a relação dos genes informativos em GM135-Tel, os iniciadores desenhados e outras informações importantes encontram-se no Anexo 2. No caso dos genes “imprintados”, a aluna de mestrado Érica Sara Souza de Araújo realizou as análises de quais genes eram informativos na linhagem GM3135-Tel; a lista dos iniciadores utilizados encontra-se no Anexo 1.

Entre $50 \mathrm{ng}$ e $100 \mathrm{ng}$ de cDNA ou DNA foram amplificados utilizando $1 \mathrm{U}$ de Taq DNA Polimerase (Amersham), 1X tampão (Amersham), $150 \mathrm{nM}$ de cada iniciador, $200 \mu \mathrm{M}$ de dNTPs (Invitrogen), numa reação de volume final $15 \mu \mathrm{L}$. Em alguns pares de iniciadores, a reação ainda continha 10\% DMSO ou 1M de betaína.

O produto das amplificações foi aplicado em gel de agarose $1 \%$ 1X TAE, em solução $1 \mathrm{X}$ TAE, submetido à eletroforese a $100 \mathrm{~V}$ por 15 minutos. Os geis de agarose foram então corados com $0,5 \mu \mathrm{g} / \mathrm{mL}$ de brometo de etídeo (Invitrogen) e visualizados sob luz ultravioleta.

Amostras de RT- (controles da contaminação com DNA) também foram submetidas às RT-PCRs, para detecção de eventuais amplificações de DNA residual não 
eliminado no tratamento; após RT-PCR, essas amostras foram submetidas à eletroforese a $100 \mathrm{~V}$ em géis de poliacrilamida $10 \%$ 1X TBE, em solução 1X TBE. Após eletroforese, os géis foram mergulhados em solução fixadora (10\% etanol, 0,5\% ácido acético) por 10 minutos, imersos em solução de nitrato de prata ( $2 \mathrm{~g} / \mathrm{L})$ por 8 minutos e posteriormente em solução reveladora ( $\mathrm{NaOH} 30 \mathrm{~g} / \mathrm{L}$ e 0,002\% de formaldeído 37\%) até visualização das bandas (protocolo modificado de Santos et al., 1993).

III. 2.15. Sequenciamento direto

Os produtos das PCRs ou RT-PCRs foram diluídos em água bidestilada autoclavada, na proporção 1:6 ou 1:4, conforme intensidade da banda observada no gel. Os produtos das RT-PCRs foram submetidos à purificação com solução 1X PEG (4,92 g acetato de sódio; $0,12 \mathrm{~g} \mathrm{MgCl}_{2} \cdot 6 \mathrm{H}_{2} \mathrm{O} ; 26,2$ g PEG800); após incubação a temperatura ambiente por 10 minutos, as amostras foram centrifugadas a temperatura ambiente por 10 minutos a $14000 \mathrm{rpm}$. O sobrenadante foi sugado e aos precipitados foram acrescentados $100 \mu \mathrm{l}$ de etanol 96\%. Nova centrifugação foi realizada, o sobrenadante foi eliminado, os precipitados foram secos a temperatura ambiente e eluídos em $3 \mu \mathrm{L}$ de água bidestilada autoclavada.

Os produtos diluídos e os purificados com solução PEG foram submetidos à reação de sequenciamento direto, utilizando o iniciador $\mathrm{F}$ (forward) ou $\mathrm{R}$ (reverse). Assim, $1 \mu \mathrm{L}$ de cada amostra foi usado na reação com $1 \mu \mathrm{L}$ de BigDye $®$ Terminator v3.1 do kit Cycle Sequencing (Applied Biosystems), 1X tampão, 120 nM de iniciador, num volume final de $15 \mu \mathrm{L}$. O programa para reação de sequenciamento consistia em 40 ciclos de $96{ }^{\circ} \mathrm{C}$ por 10 segundos $52{ }^{\circ} \mathrm{C}$ por 20 segundos; $60{ }^{\circ} \mathrm{C}$ por 4 minutos, como recomendado pela Applied Biosystems. 
Os produtos das reações de sequenciamento foram purificados em colunas Sephadex, de acordo com orientações do fabricante (Amersham), e eluídos em $10 \mu \mathrm{L}$ de formamida (Applied Biosystems). A eletroforese capilar das amostras foi realizada em sequenciador ABI3100 Prism Genetic Analyzer (Applied Biosystems), do Serviço de Sequenciamento do Departamento de Parasitologia do ICB-USP (Técnico Responsável: Marcio Massao Yamamoto), de acordo com as configurações do fabricante.

\section{2.16. Extração de proteínas}

A extração de proteínas foi realizada por rompimento das células com $100 \mu \mathrm{l}$ de tampão de lise (50 mM HEPES pH7.5, 5 mM EDTA, $150 \mathrm{mM} \mathrm{NaCl} \mathrm{e} \mathrm{0,5 \%} \mathrm{Nonidet}$ P40) e $1 \mathrm{mM}$ de PMSF (phenylmethylsulfonyl fluoride). A mistura foi agitada e mantida em gelo por 5 minutos. As amostras foram ainda homogeneizadas com 10 movimentos de seringa com agulha de 0,3 milímetros de diâmetro, e mantidas por mais 20 minutos em gelo. Em seguida as amostras foram centrifugadas a $14000 \mathrm{rpm}$ por 30 minutos a temperatura ambiente. O sobrenadante contendo as proteínas totais foi coletado, quantificado no aparelho Qubit (Invitrogen) e alíquotas de 25 ๆg de proteínas foram guardadas em freezer $-80{ }^{\circ} \mathrm{C}$.

\section{2.17. Quantificação de DNMT1 por Western Blot}

Tubos contendo as alíquotas de proteína foram retirados do freezer, e os 25 ๆg de proteínas foram desnaturados a $95^{\circ} \mathrm{C}$ por dois minutos. Em seguida, as proteínas foram submetidas à eletroforese em gel de acrilamida 8\% SDS-PAGE (sodium dodecyl sulphate - polyacrylamide gel eletrophoresis), a $100 \mathrm{~V}$ por 4 horas. $\mathrm{O}$ gel foi retirado do aparato e as amostras transferidas para membrana de nitrocelulose. A transferência 
foi realizada com tampão próprio $(25 \mathrm{mM}$ Tris- $\mathrm{HCl}, 30 \mathrm{mM}$ Glicina pH9.4 e $20 \%$ metanol), corrente de $150 \mathrm{~mA}$ e durou cerca de 1 hora.

As membranas foram coradas com Ponceau Red (Sigma) para confirmação da transferência das proteínas. Após a retirada do corante, seguiu-se incubação da membrana com tampão de bloqueio (1X TBS, 0.1\% Tween-20, 5\% leite em pó desnatado) por 1 hora a temperatura ambiente com agitação. As membranas foram então lavadas com tampão 1X TBS e depois incubadas com anticorpo anti-DNMT1 (Santa Cruz Biotechnology) diluído 1:1000 em solução 1X TBS com 5\% BSA (bovine serum albumin - Sigma). Para detecção de proteína para controle, a membrana foi incubada com anticorpo anti- $\beta$-actina diluído 1:2000 em solução 1X TBS com 5\% BSA; a incubação com os dois anticorpos primários ocorreu por 16 horas a $4{ }^{\circ} \mathrm{C}$.

No dia seguinte, as membranas foram lavadas por 3 vezes de 5 minutos com $1 \mathrm{X}$ TBS, e em seguida incubadas com anticorpo secundário antimouse (DNMT1) ou antirabbit ( $\beta$-actina) por 1 hora a temperatura ambiente com agitação. A revelação foi realizada com o kit de detecção ECL ${ }^{T M}$ Western Blotting System (Amersham), segundo instruções do fabricante.

III. 2.18. Níveis de metilação global após knockdown de DNMT1

Fibroblastos com níveis alterados de DNMT1 e fibroblastos controle foram analisados quanto aos níveis globais de metilação, por digestão do DNA destas células com HpaII. Como é sensível a metilação, a enzima de restrição HpaII não cliva sítios metilados; MspI, isoesquisômero de HpaII, não é sensível à metilação, e ensaios com esta enzima foram realizados como padrão esperado de digestão total do DNA. Para os ensaios de digestão, foi utilizado $1 \mu \mathrm{g}$ de DNA total e $1 \mathrm{U}$ de HpaII (FastDigestFermentas), ou MspI (FastDigest-Fermentas), em um volume final de $20 \mu \mathrm{L}$, com 
incubação a $37{ }^{\circ} \mathrm{C}$ por 16 horas. Os produtos das digestões foram submetidos à eletroforese em gel de agarose $1 \%$ em $1 \mathrm{X}$ TAE, a $50 \mathrm{~V}$ por 50 minutos, em solução $1 \mathrm{X}$ TAE; os géis foram corados com $0,5 \mu \mathrm{g} / \mathrm{mL}$ de brometo de etídio (Invitrogen) e visualizados em luz ultravioleta.

A análise de metilação global foi realizada por densitometria com auxílio do software Image $\mathrm{J}$, comparando-se a intensidade das bandas provenientes de digestão com MspI com as daquelas da digestão com HpaII:

$$
\% \text { de metilação }=\frac{(\mathrm{H}-\mathrm{M}) \times 100}{\mathrm{G}}
$$

Onde: H-intensidade (em pixels) da banda correspondente ao DNA digerido com HpaII (enzima sensível à metilação), M-intensidade da banda correspondente ao DNA digerido com MspI (isoesquisômero de HpaII), e G-intensidade da banda correspondente ao DNA genômico não-digerido.

III. 3. RESULTADOS

Produção dos lentivírus em células HEK293-T

As bactérias transformadas com um dos vetores de expressão de shRNAs contra XIST (duas regiões alvo), DNMT1 (duas regiões alvo) e SMCHD1 foram estriadas em placas com antibiótico (ampicilina), e colônias isoladas cresceram em meio líquido. O inóculo foi utilizado para produção e isolamento do plasmídeo em média escala (midiprep), e uma alíquota dos plasmídeos purificados foi digerida com a enzima SalI ou SacII, para confirmação da integridade dos vetores. 
Os plasmídeos foram então transfectados em células HEK-293T, juntamente com vetores de expressão de capsídeo e envelope para produção de partículas lentivirais. Após 48 horas da transfecção destas células, o sobrenadante contendo as partículas lentivirais foi coletado, alíquotado e congelado à $-80^{\circ} \mathrm{C}$.

\section{$\underline{\text { Silenciamento de DNMT1 }}$}

Fibroblastos GM135-Tel foram transduzidos com vetores lentivirais para produção de shRNAs contra a sequência do transcrito de DNMT1. Dois vetores foram adquiridos da OpenBiosystems, com sequências que alvejam regiões diferentes do RNA de DNMT1. Cerca de $2 \times 10^{4}$ fibroblastos receberam cada um dos lentivírus, $\operatorname{shDNMT}_{(1)}$ ou $\operatorname{shDNMT} 1_{(2)}$, ou uma combinação destes $\left[\operatorname{shDNMT} 1_{(1)}+\operatorname{shDNMT1} 1_{(2)}\right]$.

Após seleção com puromicina, as células foram observadas em microscópio de fluorescência invertido com o intuito de verificar a expressão de GFP (Figura 18-A). Todas as células que receberam a mistura com os dois vetores para silenciamento de DNMT1 morreram após 5 dias de seleção com puromicina. 

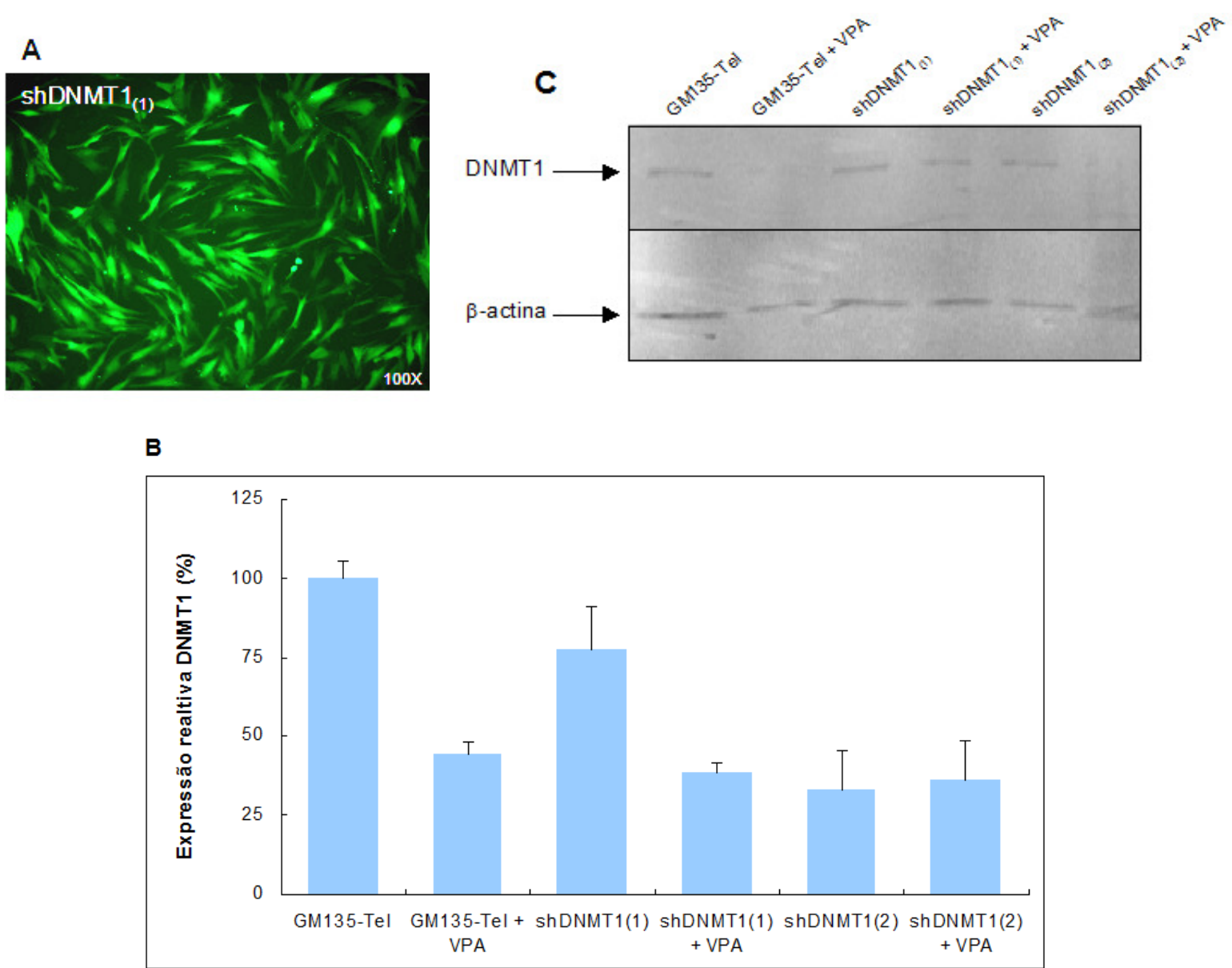

Figura 18: Expressão de DNMT1 em fibroblastos GM135-Tel transduzidos com vetores para silenciamento deste gene. Em A, microscopia de fluorescência invertida mostrando expressão de GFP, confirmando a expressão dos shRNAs. Em B, expressão de DNMT1 por RT-PCR em tempo real; a amostra GM135-Tel foi usada como referência e a expressão é relativa aos ensaios com os três normalizadores endógenos mais estáveis (genes TOP1, TBP e SHDA), calculados pelo programa geNorm. As barras representam o desvio padrão combinado entre os ensaios e as triplicatas experimentais. Em C, níveis protéicos de DNMT1 avaliados por western blot; $\beta$ actina foi usada como controle endógeno.

Não foi possível isolar clones celulares após transdução e seleção dos fibroblastos; a linhagem GM135-Tel apresenta um comportamento trabalhoso para plaqueamento em concentrações baixas, pois uma maior confluência parece ser requisito para a expansão da cultura. Como a visualização das células após transdução mostrou uma representativa porcentagem de células GFP+, para confirmarmos o silenciamento de DNMT1 resolvemos extrair o RNA do pool total de células. Acreditamos que esta metodologia possui suas limitações, uma vez que (1) para cada 
célula, o vetor pode se inserir em diferentes regiões do genoma, o que compromete os níveis de expressão do shRNA; (2) neste caso, os níveis de expressão de DNMT1 podem refletir a porcentagem de células transduzidas, e não a eficiência de vetor utilizado para silenciamento do gene.

Alguns trabalhos relatam que inibidores de proteínas do complexo de histona desacetilases (HDACs) provocam diminuição de DNMT1 (Zhou et al., 2008; Choi et al., 2010). Por esta razão, fibroblastos transduzidos com shRNAs contra DNMT1 também foram tratados com ácido valproico (VPA), um potente inibidor de HDACs. Para confirmar a diminuição de DNMT1 depois das transduções e dos tratamentos com VPA, os níveis transcricionais e protéicos foram avaliados nas células.

O tratamento com VPA causou diminuição dos níveis do transcrito de DNMT1 (44\% em relação ao controle - Figura 18-B); além disso, o VPA intensificou o silenciamento do gene nos fibroblastos transduzidos (Figura 18-B e -C). A construção $\operatorname{shDNMT1}_{(2)}$ foi mais eficaz em diminuir os níveis de expressão de DNMT1; no entanto, não se obteve redução de mais de $70 \%$ no nível dos transcritos (Figura 18-B), o que pode indicar inviabilidade das células que apresentam expressão menor de DNMT1.

A taxa de crescimento das células transduzidas foi medida; a Figura 19 mostra que as células $\operatorname{shDNMT1} 1_{(2)}$ continuaram a proliferar após o quinto dia de plaqueamento, enquanto que as culturas controle e $\operatorname{shDNMT}_{(1)}$ estabilizaram neste período. É importante dizer que a transdução não comprometeu a sobrevivência das células. 


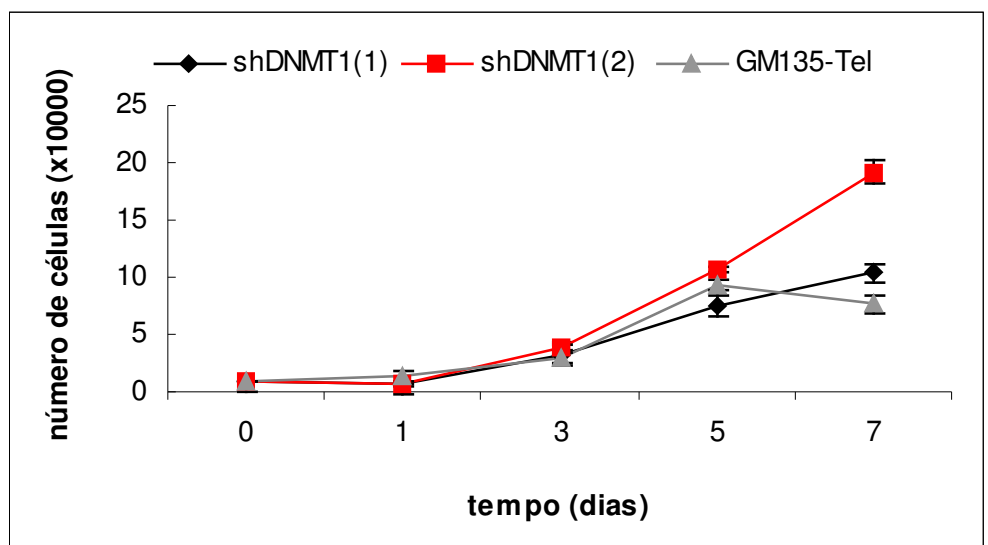

Figura 19: Taxa de crescimento de fibroblastos transduzidos com vetores para silenciamento de DNMT1. Os valores correspondem às medias de contagem entre triplicatas experimentais, e as barras representam o desvio padrão.

Efeitos do silenciamento de DNMT1

Metilação global

O grau de metilação do DNA genômico foi avaliado por digestão com enzima de restrição sensível à metilação; a análise revelou que os fibroblastos transduzidos com shRNAs contra DNMT1 e/ou tratados com VPA possuem menores níveis de metilação global quando comparados ao controle, como mostra a Figura 20; assim, a diminuição de DNMT1 por RNAi foi efetiva em promover queda na metilação global do DNA. 

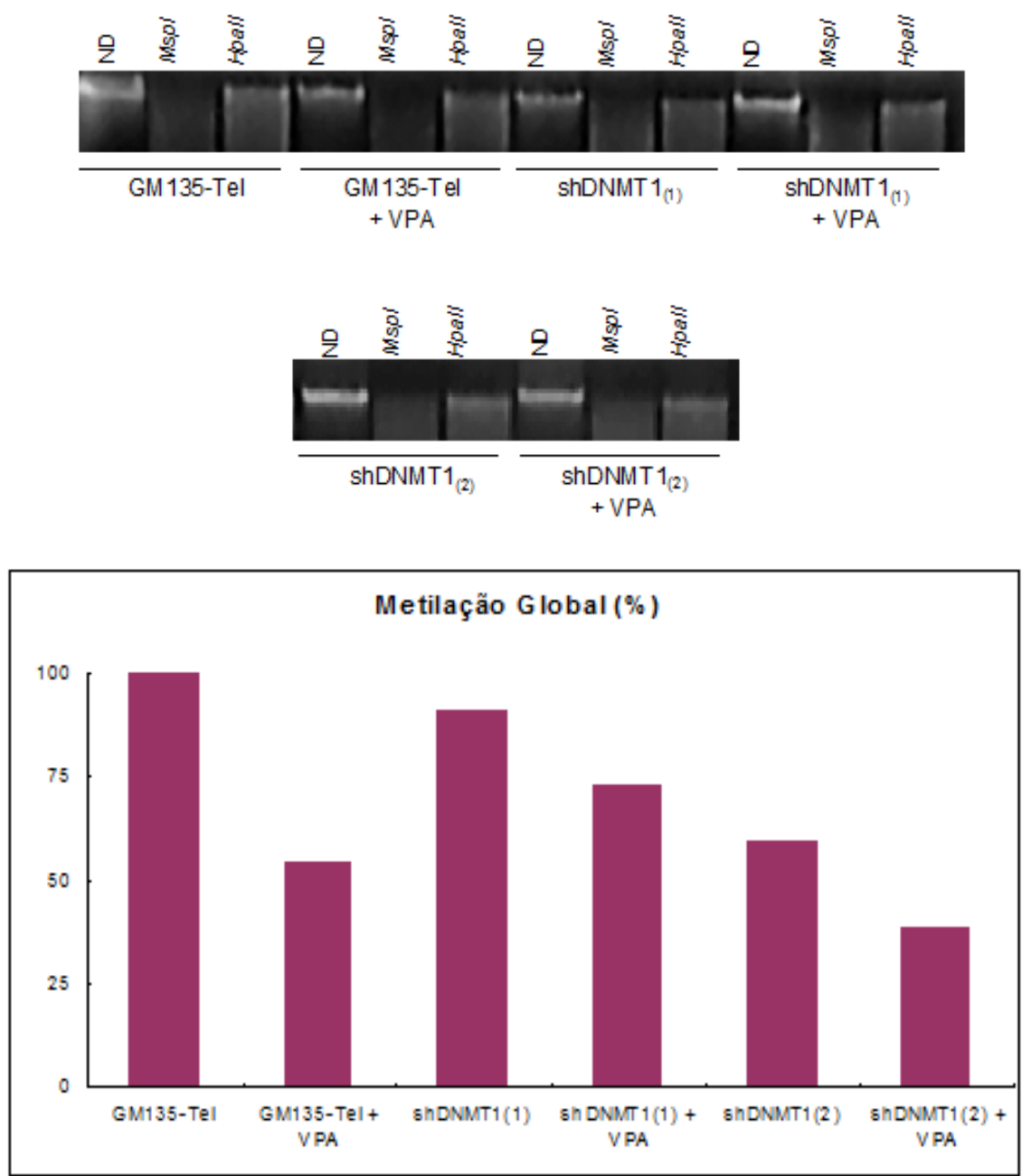

Figura 20: Nível de metilação global em fibroblastos GM135-Tel transduzidos com vetores para produção de shRNAs contra DNMT1 e tratados com VPA. Acima, gel de agarose corado com brometo de etídio mostrando as bandas correspondentes ao DNA total das células digerido com as enzimas de restrição MspI e HpaII, esta última sensível à metilação. Abaixo, porcentagem de metilação global de cada amostra em relação ao controle GM135-Tel. ND: DNA genômico não-digerido.

Expressão de genes submetidos à ICX

RT-PCRs seguidas de sequenciamento direto revelaram que a queda da metilação global não foi suficiente para ativar a maioria dos alelos anteriormente silenciados pelo processo de ICX (Tabela 7). Porém, a diminuição de DNMT1 e/ou tratamento com VPA provocaram uma redução na expressão do gene MAOA (Figura 21) e surpreendentemente reativação do alelo reprimido deste gene (Figura 22). Para 
confirmar estes resultados, outras regiões contendo cSNPs em MAOA foram analisadas (rs6323, rs3027); nas amostras de células $\operatorname{shDNMT1}_{(2)}$ e $\operatorname{shDNMT1}_{(2)}$, + VPA confirmou-se reativação do alelo de $M A O A$ (ver Tabela 7).

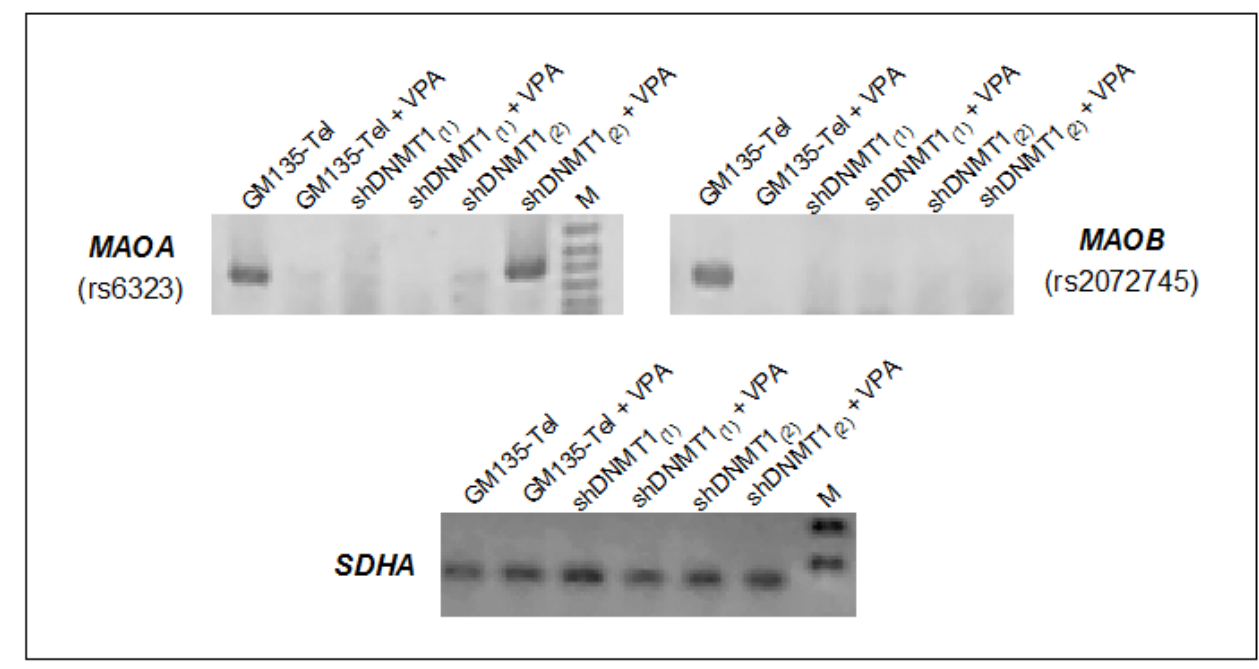

Figura 21: Expressão de $M A O A$ e $M A O B$ em fibroblastos GM135-Tel após silenciamento de $D N M T 1$, avaliada por RT-PCR. Geis de agarose corados com brometo de etídeo mostrando queda na expressão de $M A O A$ e $M A O B$ nas células transduzidas e/ou tratadas com VPA. A expressão de SDHA é usada como referência. M: marcador de peso molecular $1 \mathrm{~Kb}$ ladder (Invitrogen).

Por ser um gene próximo a $M A O A$, questionou-se se a expressão de $M A O B$ também havia sido alterada nas células transduzidas. Para investigar o perfil de expressão do gene $M A O B$, as células GM135-Tel foram genotipadas quanto à presença de cSNPs informativos no gene, e os sequenciamentos mostraram que as células são heterozigotas para o cSNP rs2072745. Entretanto, como visto em MAOA, MAOB tem sua expressão diminuída nas células GM135-Tel transduzidas (Figura 21); talvez por esta razão não foi possível avaliar a expressão alelo-específica do gene em todas as amostras (Tabela 7). 
TBL1X

rs7256
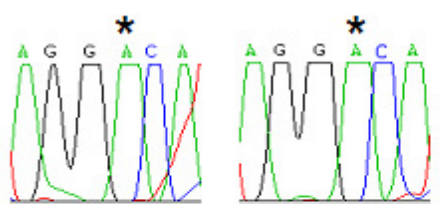

*

MAOA

rs 180291
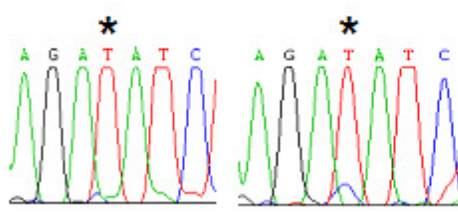

*
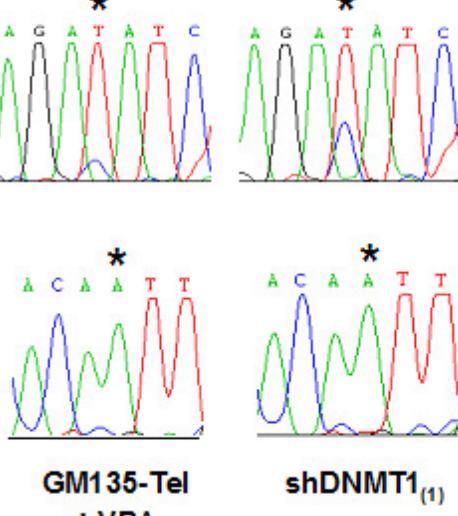

+ VPA

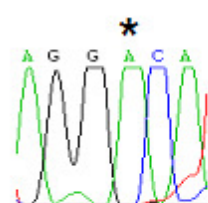

XIST

rs1894271
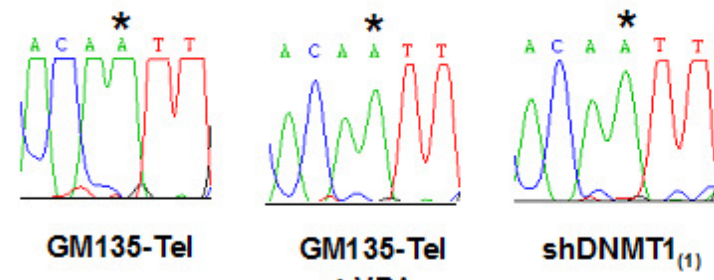
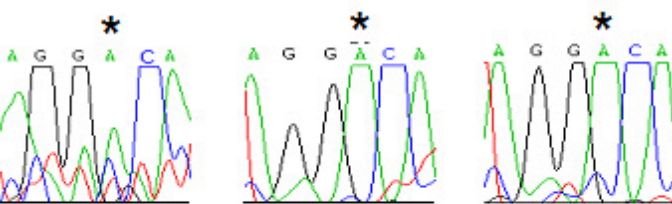

*
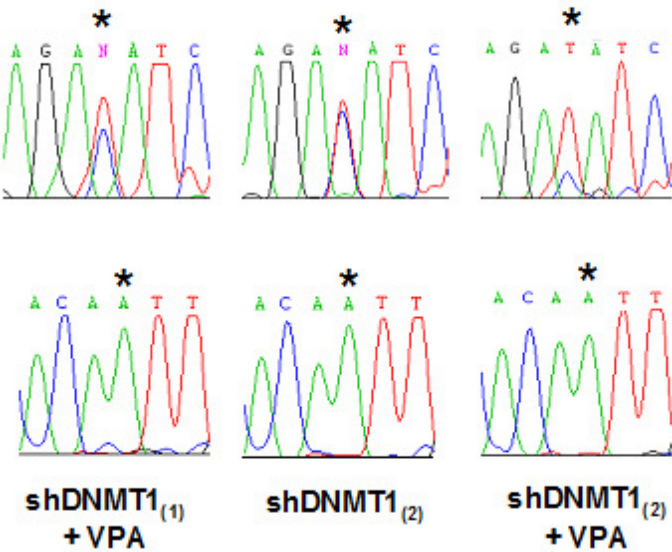

Figura 22: Reativação do alelo submetido à ICX do gene $M A O A$ após silenciamento de DNMT1 e/ou tratamento com VPA. Os eletroferogramas de dois genes submetidos à ICX (TBL1X, MAOA) e XIST (expresso pelo Xi) são exibidos, e a identificação dos SNPs está discriminada. Cada coluna representa uma sublinhagem de células GM135-Tel transduzidas com vetores para silenciamento de DNMT1. Os asteriscos situam-se na posição de cada cSNP.

Tabela 7: Expressão alelo-específica de genes ligados ao X em fibroblastos GM135-Tel após silenciamento de DNMTI e tratamento com VPA.

\begin{tabular}{|c|c|c|c|c|c|c|c|}
\hline Gene & SNP $^{*}$ & GM135-Tel & GM135-Tel + VPA & $\operatorname{shDNMT1}_{(1)}$ & $\operatorname{shDNMT1_{(1)}+\text {VPA}}$ & $\operatorname{shDNMT1}_{(2)}$ & $\operatorname{shDNMT1}_{(2)}+$ VPA \\
\hline GYG2 & rs211659 & $\mathrm{T}$ & $\mathrm{T}$ & - & - & - & -- \\
\hline TBL1X & rs7256 & $A$ & $A$ & A & A & A & A \\
\hline PIGA & rs3087965 & A & A & A & A & A & $A$ \\
\hline$Z F X^{\#}$ & rs5949242 & $\mathrm{C} / \mathrm{T}$ & $\mathrm{C} / \mathrm{T}$ & $\mathrm{C} / \mathrm{T}$ & $\mathrm{C} / \mathrm{T}$ & $\mathrm{C} / \mathrm{T}$ & $\mathrm{C} / \mathrm{T}$ \\
\hline TCTE1L & rs12849 & $\mathrm{T}$ & - & $\mathrm{T}$ & $\mathrm{T}$ & $\mathrm{T}$ & $\mathrm{T}$ \\
\hline \multirow[t]{3}{*}{ MAOA } & rs6323 & G & - & - & - & $\mathrm{G} / \mathrm{T}$ & $\mathrm{G}$ \\
\hline & rs3027 & A & -- & -- & - & -- & -- \\
\hline & rs180291 & $\mathrm{T}$ & $\mathrm{T}>\mathrm{C}$ & $\mathrm{T}>\mathrm{C}$ & $\mathrm{T} / \mathrm{C}$ & $\mathrm{T} / \mathrm{C}$ & $\mathrm{T}>\mathrm{C}$ \\
\hline MAOB & rs2072745 & $\mathrm{T}$ & $\mathrm{T}$ & - & - & -- & - \\
\hline SUV39H1 & rs3373 & G & G & $\mathrm{G}$ & $\mathrm{G}$ & G & - \\
\hline \multirow[t]{3}{*}{ XIST } & rs1894271 & A & A & A & A & A & A \\
\hline & rs16992436 & $\mathrm{G}$ & $\mathrm{G}$ & $\mathrm{G}$ & $\mathrm{G}$ & $\mathrm{G}$ & - \\
\hline & rs 16992443 & A & A & A & A & A & - \\
\hline TCEAL4 & rs110110 & $\mathrm{T}$ & $\mathrm{T}$ & $\mathrm{T}$ & $\mathrm{T}$ & $\mathrm{T}$ & $\mathrm{T}$ \\
\hline GPC4 & rs1048369 & A & A & A & A & A & A \\
\hline
\end{tabular}

Genes dispostos de acordo com a sua organização cromossômica; linha tracejada representa 0 centrômero; expressão preferencial indicada por (>).

*Identificação de acordo com NCBI

\#gene que escapa à inativação (expressão bialélica)

- sequenciamento inconclusivo

- - sem amplificação ou produto de RT-PCR pouco concentrado 
Expressão de genes "imprintados"

Até o momento, foi avaliado o padrão de expressão de três genes "imprintados", de um total de seis genes informativos nesta linhagem. Após silenciamento de DNMT1, a expressão dos genes avaliados se manteve monoalélica ou preferencial (Tabela 8) em todas as amostras analisadas.

Tabela 8: Padrão de expressão de genes "imprintados" em células GM135-Tel após silenciamento de DNMT1 e/ou tratamento com VPA.

\begin{tabular}{|c|c|c|c|c|c|c|c|}
\hline Gene & SNP* $^{*}$ & GM135-Tel & GM135-Tel + VPA & $\operatorname{shDNMT1}_{(1)}$ & $\operatorname{shDNMT1}_{(1)}+$ VPA & $\operatorname{shDNMT1}_{(2)}$ & $\operatorname{shDNMT1}_{(2)}+$ VPA \\
\hline MEG3 & rs11160608 & - & A & A & - & - & A \\
\hline ATP10A & rs2076744 & $A / G$ & $A>g$ & $A>g$ & $A>g$ & $A / G$ & $A>g$ \\
\hline PEG10 & rs13073 & C & C & - & C & C & C \\
\hline
\end{tabular}

*Identificação de acordo com o NCBI

- sequenciamento inconclusivo; expressão preferencial indicada por (>)

\section{$\underline{\text { Silenciamento de XIST }}$}

Dois vetores para produção de shRNAs contra o transcrito do gene XIST foram adquiridos da empresa OpenBiosystems: um destes vetores é indutível (pTRIPZ-XIST), e sua expressão é ativada por doxiciclina.

A integridade dos vetores para silenciamento de XIST humano indutível e nãoindutível foi confirmada por digestão com enzimas de restrição. Após produção dos plasmídeos em média escala, estes foram transfectados em células produtoras HEK293 juntamente com vetores para produção do capsídeo e envelope lentivirais.

O sobrenadante viral foi coletado, filtrado e congelado, e experimentos de transdução em células GM135-Tel foram conduzidos. Cinco situações experimentais foram promovidas:

1) Fibroblastos controle não transduzidos;

2) Fibroblastos não transduzidos tratados por 3 dias com doxiciclina; 
3) Fibroblastos transduzidos com pTRIPZ-XIST;

4) Fibroblastos transduzidos com pGIPZ-XIST;

5) Fibroblastos transduzidos com pGIPZ-XIST + pTRIPZ-XIST

Após transdução, 10 dias de seleção com puromicina nas células transduzidas, e (para as transduzidas com vetor indutível) três dias de indução com doxiciclina, as células foram observadas em microscópio invertido de fluorescência. A expressão de pGIPZ-XIST pode ser monitorada pela marcação com a proteína GFP (green fluorescent protein); o elemento responsivo à tetraciclina (doxiciclina), responsável pela indução, também induz a expressão de Turbo RFP (red fluorescent protein). Desta forma, é possível confirmar a indução de expressão dos shRNA pela avaliação direta de células marcadas.

Foi possível observar ampla expressão de GFP nestas células após seleção, enquanto que foi observada expressão de RFP somente nas células após indução com doxiciclina por três dias (Figura 23). Fibroblastos transduzidos com a combinação pGIPZ-XIST + pTRIPZ-XIST possuíam alterações morfológicas e não sobreviveram ao tempo de seleção com puromicina.
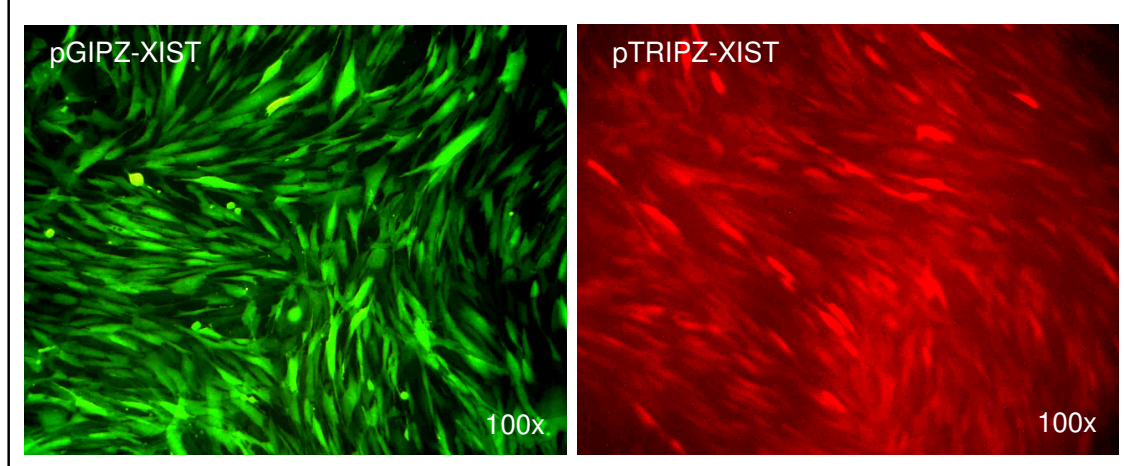

Figura 23: Expressão de shRNAs contra o gene XIST em células GM135Tel, monitoradas pela expressão de GFP (pGIPZXIST) e RFP (pTRIPZ-XIST). Os aumentos estão indicados. 
Os níveis do transcrito de XIST depois das transduções foram investigados por RT-PCR em tempo real. No entanto, dependendo do gene de controle endógeno utilizado, resultados muito discrepantes foram obtidos. Para saber quais os endógenos mais estáveis neste ensaio, foi utilizado o aplicativo geNorm VBA. Para ilustrar essas diferenças, a Figura 24 mostra a quantificação absoluta de cada gene endógeno (valores CTs médios).

Os valores dos CTs indicam o número do ciclo em que cada amostra alcançou uma mesma intensidade de fluorescência. Por essa avaliação, um gene normalizador adequado deveria ter valores de CTs idênticos ou bem próximos entre as diferentes amostras. Pode-se observar que a menor variação de expressão encontrada foi obtida com os genes $H M B S$ (desvio padrão entre as amostras $=1,19$ ) e $Y W H A Z 1$ (desvio padrão entre as amostras $=0,9)$. Esses valores estão ainda muito aquém do esperado, pois uma diferença de 1 (um) ciclo no valor de CT entre uma amostra e outra denota variação de 50\% no nível de expressão ou na quantidade de cDNA inicial, o que não foi o caso.

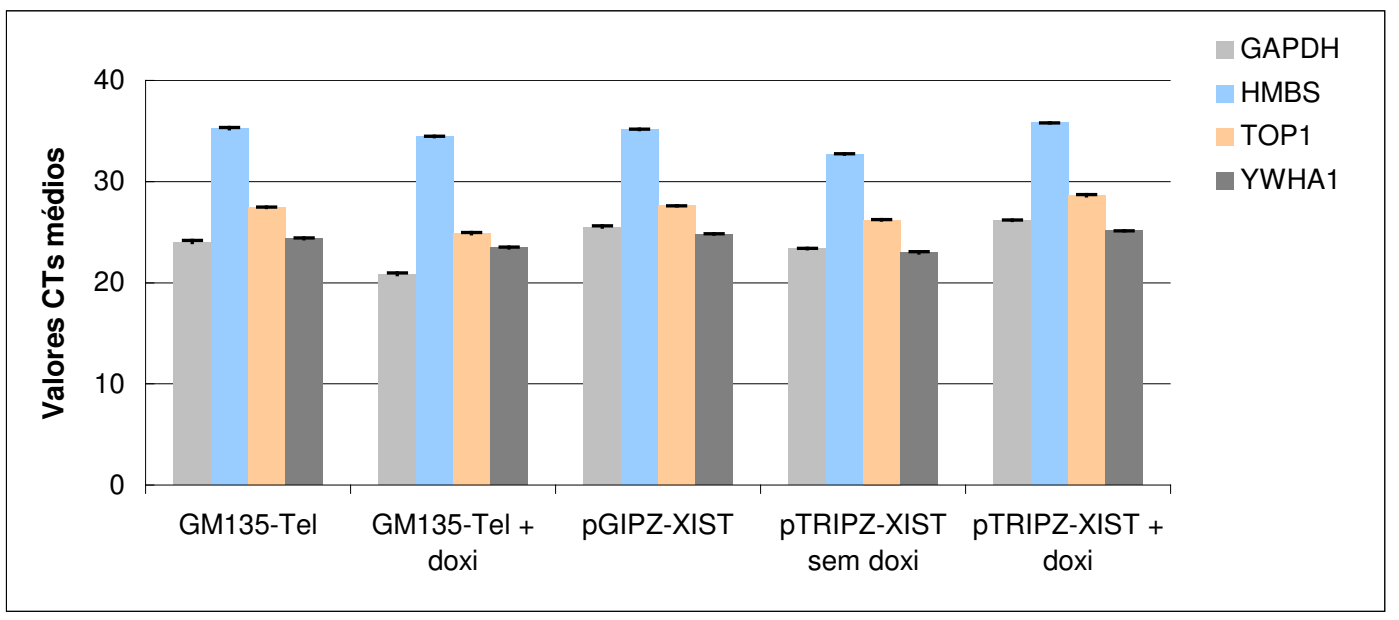

Figura 24: Comparação dos valores de CTs médios para quatro genes normalizadores entre as amostras de fibroblastos transduzidos com vetores para produção de shRNAs contra XIST. As barras correspondem aos desvios-padrão encontrados em triplicatas experimentais. 
Os resultados mostram também que a doxiciclina altera a expressão dos genes normalizadores, como visto nas células não transduzidas tratadas com a droga, o que poderia invalidar as considerações feitas em fibroblastos GM135-Tel transduzidos com vetores indutíveis.

A Figura 25 exibe a expressão de XIST por RT-PCR em tempo real, relativa à expressão dos genes $Y W H A Z$ e $H M B S$ usados como normalizadores. Os resultados encontrados foram incoerentes; além de variação entre os ensaios ser grande (até $25 \%$ ), a menor expressão de XIST, surpreendentemente, foi obtida nas células que receberam o vetor pTRIPZ-XIST sem indução com doxiciclina ("pTRIPZ-XIST sem doxi”), sugerindo que o short hairpin poderia já estar sendo expresso nas células transduzidas.

Os dados de expressão de XIST nas células transduzidas com os vetores indutíveis foram inconclusivos, já que em fibroblastos GM135-Tel a doxiciclina parece interferir na expressão gênica per se. Por este motivo, um novo conjunto de normalizadores endógenos está sendo pesquisado e os experimentos com estas células foram interrompidos.

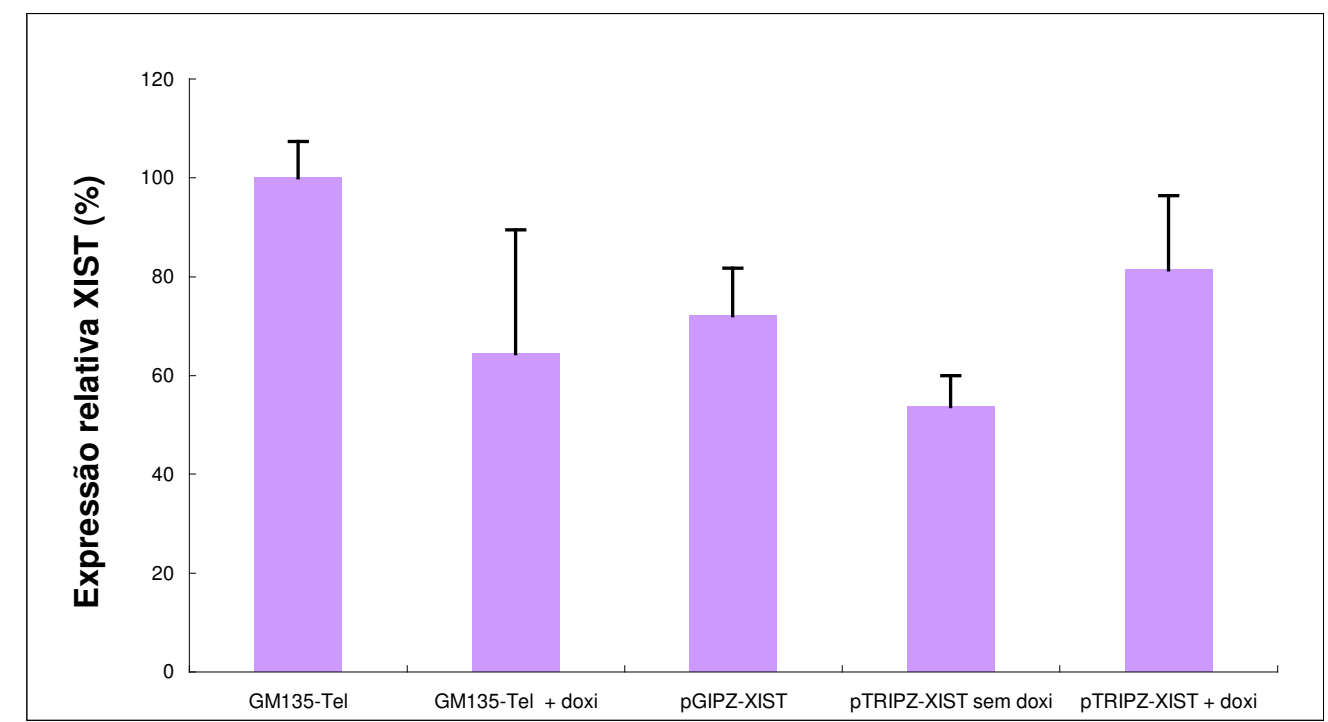

Figura 25: Expressão de XIST em fibroblastos GM135-Tel transduzidos com vetores para silenciamento deste gene. Os valores referem-se aos ensaios usando YWHAZ e HMBS como normalizadores endógenos e a amostra GM135-Tel como referência (100\%). As barras são os desvios-padrão da combinação entre as triplicatas experimentais. 
A Figura 26 mostra que não houve diminuição na viabilidade das células transduzidas, pois a taxa de crescimento é comparável àquelas referentes aos fibroblastos controle.

Fibroblastos transduzidos com o vetor não-indutível pGIPZ-XIST possuem em média $25 \%$ de diminuição de XIST; células pTRIPZ-XIST sem doxiciclina alcançaram diminuição de aproximadamente $40 \%$ de expressão de XIST. O perfil de expressão de alguns genes submetidos à ICX foi acessado nestas células, e até o momento não foi observada nenhuma alteração, os seja, a expressão permanece monoalélica (Tabela 9).

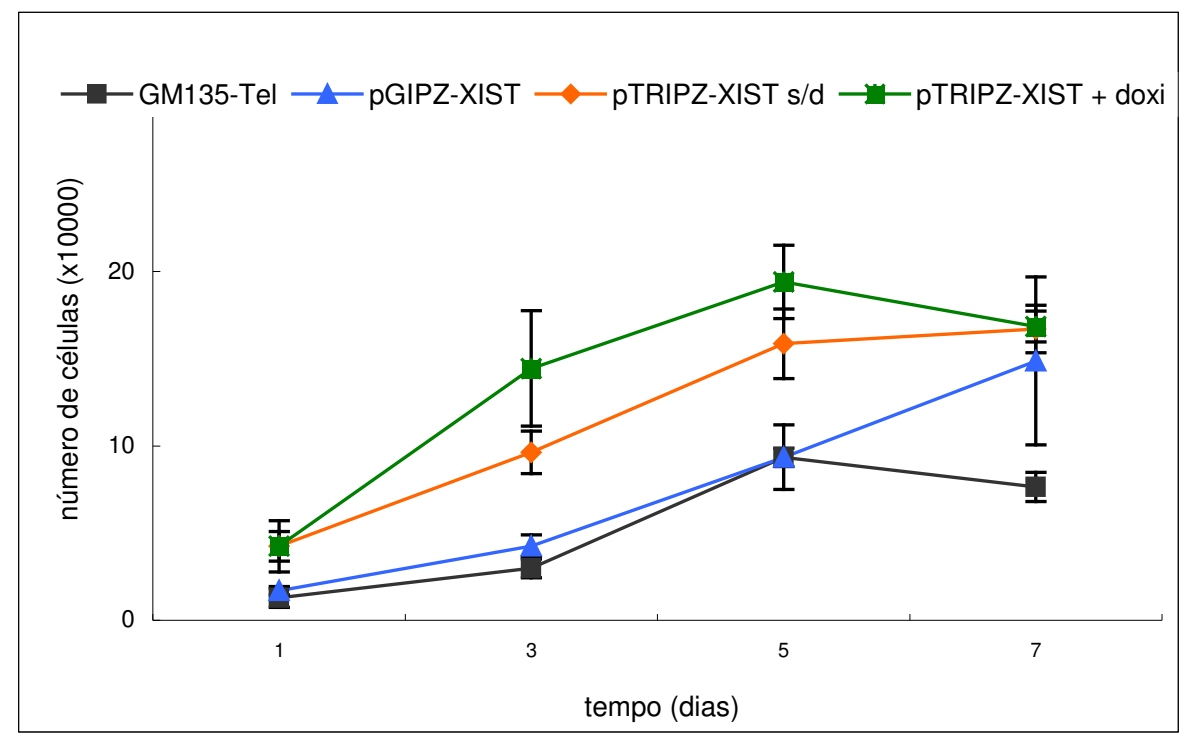

Figura 26: Taxa de crescimento de fibroblastos transduzidos com vetores para silenciamento de $X I S T$. Os valores correspondem às medias de contagem entre triplicatas experimentais, e as barras, os desviospadrão. s/d - sem adição de doxiciclina.

Tabela 9: Expressão alelo-específica de genes ligados ao $\mathrm{X}$ em fibroblastos GM135-Tel após silenciamento de XIST.

\begin{tabular}{|c|c|c|c|c|}
\hline Gene & SNP $^{*}$ & GM135-Tel & pGIPZ-XIST & pTRIPZ-XIST \\
\hline TBL1X & rs7256 & $\mathrm{A}$ & $\mathrm{A}$ & $\mathrm{A}$ \\
PIGA & $\mathrm{rs} 3087965$ & $\mathrm{~A}$ & $\mathrm{~A}$ & $\mathrm{~A}$ \\
ZFX & $\mathrm{rs} 5949242$ & $\mathrm{C} / \mathrm{T}$ & $\mathrm{C} / \mathrm{T}$ & $\mathrm{C} / \mathrm{T}$ \\
TCTE1L & $\mathrm{rs} 12849$ & $\mathrm{~T}$ & $\mathrm{~T}$ & $\mathrm{~T}$ \\
SUV39H1 & $\mathrm{rs} 3373$ & $\mathrm{G}$ & $\mathrm{G}$ & $\mathrm{G}$ \\
\hline TCEAL4 & $\mathrm{rs} 110110$ & $\mathrm{~T}$ & $\mathrm{~T}$ & $\mathrm{~T}$ \\
GPC4 & $\mathrm{rs} 1048369$ & $\mathrm{~A}$ & $\mathrm{~T}$ & $\mathrm{~T}$ \\
\hline
\end{tabular}

Genes dispostos de acordo com a sua organização cromossômica Linha tracejada representa o centrômero

*Identificação de acordo com NCBI

\#gene que escapa à inativação (expressão bialélica) 


\section{$\underline{\text { Silenciamento de SMCHD1 }}$}

Células GM135-Tel foram transduzidas com o vetor de expressão de shRNAs contra o gene SMCHD1 (shSMCHD1). Após seleção e indução com doxiciclina, as células foram observadas em microscópio de fluorescência invertido, o que revelou um número reduzido de células expressando RFP (Figura 27).

Da mesma maneira que o vetor para knockdown de XIST indutível, a análise da expressão de $S M C H D 1$ foi prejudicada pela alteração nos níveis de expressão dos genes normalizadores após a transdução. A quantificação relativa da expressão de SMCHD1 foi realizada usando os genes normalizadores endógenos mais estáveis $H M B S$ e YWHAZ. Não houve diminuição da expressão de SMCHD1, como vemos por RT-PCR em tempo real (Figura 26). Ao contrário, por esta análise, após adição de doxiciclina, a expressão de SMCHD1 dobrou, sugerindo que a transdução com o vetor não foi capaz de provocar silenciamento gênico.
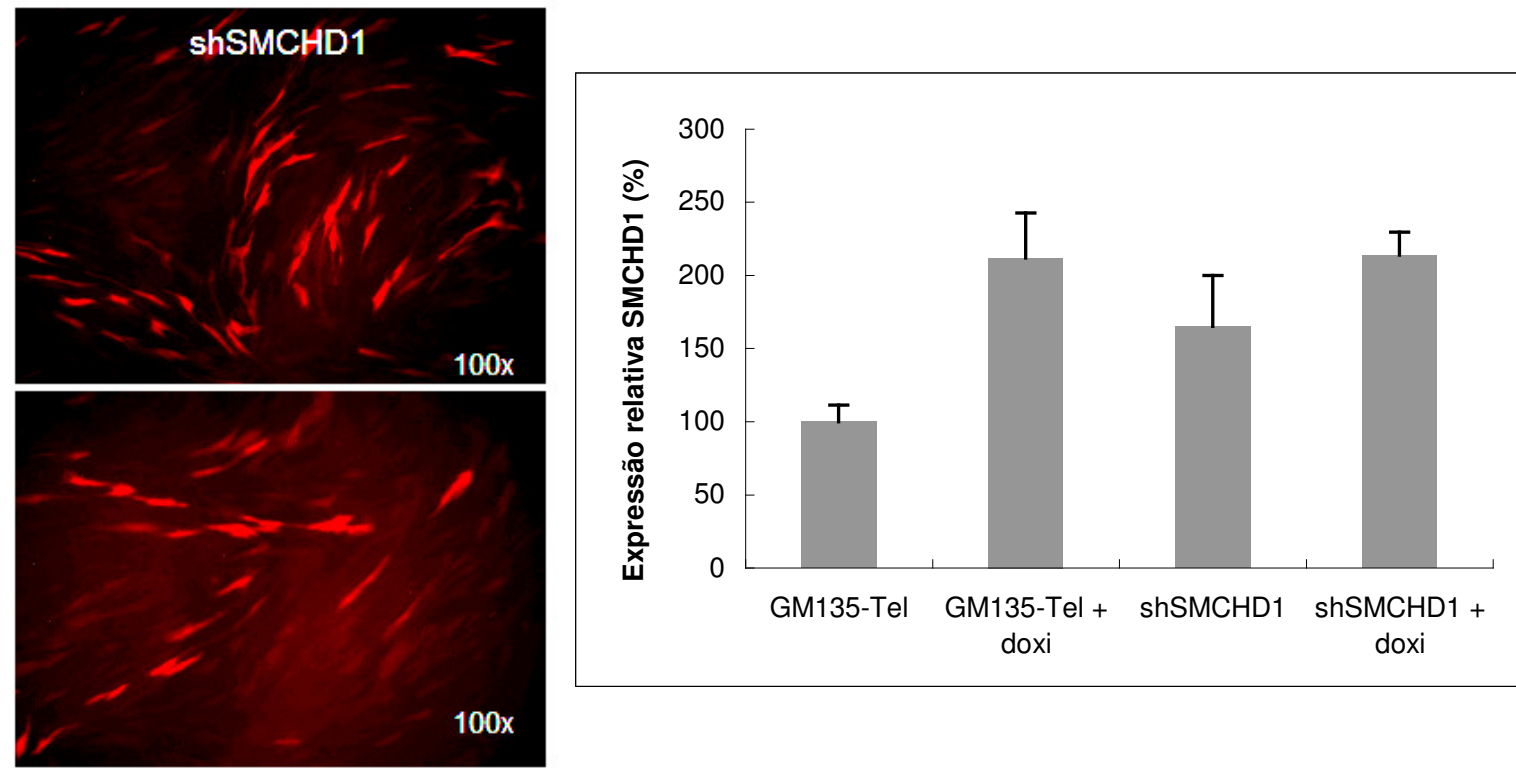

Figura 27: Expressão de $S M C H D 1$ em fibroblastos GM135-Tel transduzidos com vetores para silenciamento deste gene. À esquerda, imagens de microscopia de fluorescência invertida mostrando baixa expressão de RFP nas células transduzidas. À direita, expressão de SMCHD1 avaliada por RT-PCR em tempo real, indicando ineficiência do silenciamento por RNAi. Os ensaios são referentes à média da quantificação relativa entre o alvo (SMCHD1) e os dois genes endógenos mais estáveis (YWHAZ e HMBS), e a amostra GM135-Tel como referência (100\%). As barras referem-se ao desvio padrão da média entre as triplicatas. 
Devido à incoerência entre os valores de expressão encontrados após as transduções com vetores indutíveis para silenciamento de XIST e SMCHD1, foi inviável interpretar os resultados da análise de expressão alelo-específica de genes ligados ao X, uma vez que eventuais mudanças poderiam ser erroneamente interpretadas com alterações globais procedentes da ação direta ou indireta da droga.

\section{4. DISCUSSÃO}

\section{Silenciamento de DNMT1}

Neste trabalho, foram selecionadas duas sequências para alvejar o transcrito de DNMT1. Os resultados mostraram que os alvos tiveram diferentes eficiências no silenciamento do gene, sendo que os menores valores de expressão foram alcançados com a construção $\operatorname{shDNMT1}(2)$. A transdução com os dois vetores em conjunto resultou em morte celular, sugerindo que a transdução não foi bem-sucedida, ou que talvez níveis de DNMT1 muito baixos comprometam a sobrevivência das células. De fato, Loughery e colaboradores (2011) verificaram que o silenciamento de até $90 \%$ de DNMT1 por RNAi em fibroblastos humanos prejudicou a viabilidade celular.

Além disso, aqueles autores verificaram que ocorreu desmetilação das DMRs (do inglês differential methylation region) dos genes "imprintados" H19 e SNRPN, porém não foi verificado se a desmetilação das DMRs levava a uma mudança efetiva no padrão de expressão dos genes. Em nossas análises de expressão alelo-específica, não foram observadas alterações no padrão de expressão dos três genes "imprintados" analisados, MEG3, ATP1OA e PEG10; outros genes informativos na linhagem GM135- 
Tel serão investigados, além do perfil de metilação das DMRs associadas. No modelo murino nocaute para Dnmt1, Li e colaboradores (1993) verificaram que houve mudança no padrão de expressão dos genes Igf2, H19, Igf $2 r$. Nossos resultados em células humanas normais sugerem que o papel de DNMT1 no controle do imprinting pode ser distinto entre humanos e camundongos.

Em células humanas transformadas, no entanto, o duplo nocaute DNMT1 e DNMT3B (células DKO), com diminuição de $95 \%$ na metilação global, provocou reativação de IGF2 (Rhee e colaboradores, 2002), PEG10 e H19 (Araújo, 2012). Resultados obtidos em nosso laboratório indicam ainda que células HCT116 (transformadas) e células GM135-Tel (normais e imortalizadas) comportam-se de maneira diferente em resposta a perturbações epigenéticas. Enquanto os tratamentos com o agente desmetilante 5-azadeoxicitidina e com VPA não foram capazes de alterar a expressão de genes submetidos à ICX nem “imprintados” em células GM135-Tel, os mesmos causaram expressão bialélica de genes "imprintados" e ativação de XIST no único X em células HCT116, indicando que células humanas normais possuem controle epigenético mais rígido do que as transformadas.

No presente trabalho, em relação ao estado de atividade do $\mathrm{Xi}$ nas células deficientes para DNMT1, dos 10 genes submetidos à ICX analisados, somente MAOA apresentou derrepressão do alelo do Xi. Este é o primeiro relato de re-expressão de um gene submetido à ICX em células humanas normais. Stabellini (2008), utilizando as mesmas células GM135-Tel, verificou que a diminuição de DNMT1 por RNAi provocou desmetilação nas regiões promotoras dos genes MAOA e XIST; entretanto, não houve reativação dos alelos submetidos à ICX destes ou de outros genes ligados ao X. Em seu trabalho, a diminuição de DNMT1 também causou aumento de expressão de DNMT3B, o que indica uma possível compensação de função entre DNMTs em 
humanos. Em breve serão conduzidos experimentos de RT-PCR em tempo real para verificar se em nossas células houve compensação entre as DNMTs, como observado por Stabellini (2008).

As únicas diferenças metodológicas entre este trabalho e o de Stabellini (2008) foram o uso de vetores e regiões-alvo diferentes de DNMT1, e o tratamento com VPA. É possível que o tratamento com VPA contribua para a derrepressão de $M A O A$, uma vez que já foi possível observar um ligeiro aumento de expressão do alelo reprimido no eletroferograma correspondente ao sequenciamento da amostra GM135-Tel + VPA (Figura 22). A metilação da região promotora de $M A O A$ nas células aqui descritas será acessada em experimentos posteriores.

Várias evidências sugerem que existam diferenças no que diz respeito à cinética da inativação entre as regiões do cromossomo X. Genes mais próximos do XIC seriam silenciados antes, durante a diferenciação (Lin et al., 2007; Patrat et al., 2009). Entretanto, parece que esta regra não se aplica rigidamente a regiões distantes do XIC; a heterogeneidade na cinética e na eficiência da ICX ao longo do cromossomo X sugere que o processo pode ser regulado por mecanismos distintos, dependendo da região cromossômica avaliada (revisto por Chow \& Heard, 2009).

Além do mais, isso levanta a possibilidade de que, para algumas regiões do cromossomo $\mathrm{X}$, possa existir um mecanismo de silenciamento independente de Xist (revisto por Chow \& Heard, 2009), com diferentes níveis de regulação epigenética. De fato, Hansen e colaboradores (2000) verificaram que, em células deficientes em Dnmt3b, nas quais o Xi está hipometilado, somente um grupo de genes torna-se transcricionalmente ativo. Oda e colaboradores (2006) também verificaram que em um agrupamento de genes homeobox localizado no X a metilação independe da ICX. 
MAOA (monoaminaoxidase A) é uma das enzimas que catalisa a oxidação de aminas biogênicas; seu envolvimento em múltiplos distúrbios psiquiátricos e desordens do sistema nervoso central já foi relatado, como no comportamento antissocial, ansiedade, desordem de hiperatividade e déficit de atenção, distúrbio bipolar e Alzheimer (revisto por Shih \& Thompson, 1999). O gene MAOA está situado em Xp11.3. Em modelos animais, machos de camundongos nocautes para Maoa apresentam comportamento agressivo-ofensivo (Seif \& De Maeyer, 1999). Por estes motivos, MAOA é alvo de intensa investigação no ramo da neurologia, e uma classe de medicamentos antidepressivos tem como foco a via de atuação desta enzima.

Estudos sobre o perfil de expressão de $M A O A$ em relação à ICX humana são conflitantes; Nordquist e Oreland (2006) afirmaram que MAOA é submetido à ICX em fibroblastos humanos, enquanto que Carrel \& Willard (2005), utilizando células somáticas híbridas humano-roedor, classificaram $M A O A$ entre os $15 \%$ de genes localizados no cromossomo $\mathrm{X}$ que escapam à inativação. Stabellini e colaboradores (2008) reavaliaram essa questão em fibroblastos GM135-Tel, e verificaram expressão monoalélica de MAOA, concluindo que o gene é submetido à ICX em fibroblastos humanos.

Em nosso trabalho observou-se reativação do alelo reprimido de $M A O A$ após queda nos níveis de metilação global; por ter sido um fenômeno restrito a este gene, elementos isoladores podem estar envolvidos, uma vez que existe um sítio de ligação para CTCF próximo ao gene MAOA. Por outro lado, como não foi observada derrepressão de outros genes ligados ao $\mathrm{X}$, sugerimos que a regulação de $M A O A$ em células somáticas humanas é determinada por outros mecanismos além daqueles envolvidos na ICX. O perfil de expressão de outros genes próximos ao MAOA como 
$N B P, E F H C 2$ e $F U N D C 1$ será avaliado, no intuito de saber se a reativação alélica é específica de $M A O A$ ou se abrange outros loci.

Seria esperado que a expressão bialélica de $M A O A$ causasse aumento e não queda de expressão do gene. Apesar de não ter sido feita uma análise quantitativa, a hipótese proposta é que, com a reativação do alelo reprimido, as células possuiriam o dobro de produto do gene MAOA se comparadas à linhagem parental GM135-Tel. Poderia haver então um mecanismo de silenciamento global de $M A O A$ nos dois alelos, até uma relativa estabilização a níveis toleráveis/fisiológicos da proteína. A grande questão é saber que mecanismo seria responsável por este silenciamento, pois tanto a metilação do DNA quanto a desacetilação de histonas estão sendo perturbados nos nossos modelos.

\section{Silenciamento de XIST e de SMCHD1}

\section{Particularidades do RNA de XIST}

A princípio, poder-se-ia pensar que RNAs longos nucleares (long non-coding RNAs - lncRNAs) como o transcrito de Xist são menos passíveis de sofrer silenciamento via siRNA (small interfering RNAs), porque a degradação baseada em RNAi ocorre predominantemente no citoplasma (Ketting, 2011). No entanto, um estudo publicado por Matoba e colaboradores (2011) obteve bons resultados ao ter como alvo Xist murino. O objetivo dos autores era aumentar a eficiência de produção de clones por transferência nuclear somática.

A clonagem por transferência nuclear somática em mamíferos é ainda um processo muito ineficaz, e erros de reprogramação do genoma doador são frequentes. Em 2010, Inoue e colaboradores observaram que Xist era ectopicamente expresso a 
partir do $\mathrm{X}$ ativo em clones produzidos por transferência nuclear, em camundongos de ambos os sexos. A deleção do gene Xist aumentava em até oito vezes a eficiência de clonagem e restaurava a expressão gênica global, o que indicou que a desregulação de Xist poderia estar diretamente associada com a baixa eficiência de clonagem em mamíferos.

Matoba e colaboradores (2011) relataram o uso de siRNAs sintéticos contra o transcrito de Xist (siRNA-Xist) em clones do sexo masculino que, assim como o nocaute de Xist, provocaram aumento nas taxas de nascimento. O tratamento combinado de siRNA-Xist com $50 \mathrm{nM}$ de tricostatina A (TSA), um inibidor de histona desacetilase, contribuiu ainda mais para o aumento na eficiência de clonagem, indicando um efeito sinergístico desses dois fatores. Contudo, os autores obtiveram esses resultados somente quando o tratamento foi realizado em mórulas, não em blastocistos, sugerindo que existe uma estreita janela temporal de regulação de Xist durante o desenvolvimento. Mais importante, o knockdown de Xist provocou reativação de genes ligados ao X e, surpreendentemente, de alguns genes autossômicos.

Como dito anteriormente, o sucesso no silenciamento de Xist obtido por Motoba e colaboradores (2011) foi visto com surpresa mesmo para os autores em questão, dado que Xist é um RNA longo nuclear que não sai do núcleo, não podendo ser alvo de silenciamento via RNAi citoplasmática. O trabalho não investigou a cinética destes siRNAs quando injetados nos embriões, mas sugeriu que a interferência pudesse ter ocorrido durante a metáfase, momento em que a carioteca se desfaz e os RNAs nucleares poderiam encontrar a maquinaria de silenciamento no citoplasma, como já foi relatado por Amanai e colaboradores (2006).

Outra possibilidade seria que o silenciamento ocorresse mesmo no núcleo. Diversos trabalhos já indicaram a existência de um mecanismo de silenciamento 
nuclear; em C. elegans, proteínas específicas da família das Argonautas (NRDE nuclear RNAi defective) são capazes de transportar siRNAs citoplasmáticos até o núcleo (Guang et al., 2008), onde inibem a atividade da RNA polimerase II durante a elongação da transcrição (Guang et al., 2010). Em mamíferos, de maneira geral, as evidências apontam para a existência de componentes da maquinaria de silenciamento como as proteínas Dicer e Ago2 no núcleo, mas a função destas neste compartimento celular ainda requer investigação. Sugere-se que o mecanismo de silenciamento nuclear ocorra por modulação específica da estrutura da cromatina, o que define a expressão do gene ou região-alvos (Ketting, 2011). Vale ressaltar que Robb e colaboradores (2005) descreveram o silenciamento gênico por RNA exógeno em núcleos de linhagens celulares humanas, confirmando a possibilidade de ocorrer interferência por RNA no núcleo.

No que se refere ao silenciamento de Xist, comparando-se este trabalho com o de Matoba e colaboradores (2011), importantes diferenças quanto ao desenho experimental e ao modelo estudado precisam ser consideradas:

1) os autores trabalharam com clones masculinos, embriões cuja condição normal é que os genes ligados ao $\mathrm{X}$ estejam sendo transcritos. Em outras palavras, machos em condições normais de desenvolvimento possuem o único $\mathrm{X}$ ativo; $\mathrm{o}$ tratamento com siRNAs resgatou embriões comprometidos que, por expressão ectópica de Xist, morriam. É possível que, no caso de clones femininos, o tratamento com siRNA contra Xist fosse letal, pois a partir de determinada fase do desenvolvimento embrionário feminino, um dos cromossomos $\mathrm{X}$ precisa ser recoberto por Xist $\mathrm{e}$ inativado;

2) com o intuito de silenciar XIST humano, neste trabalho procuramos transduzir fibroblastos humanos com vetores de expressão contendo shRNAs que alvejassem 
XIST, enquanto que Matoba e colaboradores (2011) injetaram RNAs interferentes (siRNAs) sintéticos diretamente nos embriões. Essa pode ter sido a razão pela qual os autores conseguiram resultados melhores do que os aqui relatados, uma vez que nossa estratégia dependia de vários eventos para que houvesse sucesso no knockdown de XIST: integração do vetor no genoma hospedeiro, produção do hairpin de siRNA-XIST, processamento para produção da dupla-fita e alvejamento de RNA de XIST;

3) como relatado por Matoba e colaboradores (2011), houve uma janela crítica de atuação dos siRNAs, fora da qual não houve efeito de diminuição de Xist. Esse intervalo durante o desenvolvimento pode ser alvo de regulação ativa de Xist/XIST. De fato, a injeção de siRNA-Xist em embriões pré-implantação fez diminuir a expressão ectópica de Xist, porém esta foi restabelecida na fase de blastocisto. Nosso trabalho teve como modelo células somáticas humanas, terminalmente diferenciadas, situadas talvez em período posterior à janela de regulação de XIST permitida, o que dificultou o silenciamento do gene. Mesmo assim, vale relembrar que Hall e colaboradores (2002) conseguiram ativar e inativar a expressão ectópica de XIST em células somáticas, contrariando a hipótese descrita.

Uma causa para o silenciamento pouco expressivo de XIST deste trabalho pode ter sido as sequências-alvo contra XIST. As duas sequências utilizadas (pTRIPZ-XIST e pGIPZ-XIST) e aquela usada por Motoba e colaboradores (2011) situam-se no exon 1 do transcrito de Xist/XIST, ou seja, todas concentram-se na porção mais 5' do gene. A sequência do gene Xist murina e humana possui muitas regiões repetitivas em tandem (Brown et al., 1992), e a sequência-alvo inserida no pTRIPZ-XIST alveja uma dessas regiões.

Stabellini (2008) conseguiu silenciar 80\% de XIST por RNAi na linhagem HEK293, células transformadas derivadas de rim embrionário. Mesmo alcançando níveis tão 
baixos de XIST, não foram observadas mudanças no padrão de expressão dos genes submetidos à ICX nestas células; a localização do RNA de XIST, investigada por FISH de RNA, também não revelou variação no padrão de expressão nuclear. Esta intrigante constatação traz consigo outro questionamento, sobre o que responderia pela manutenção da associação do RNA de XIST com o Xi, mesmo depois de diminuição tão expressiva do genes. De acordo com os resultados aqui obtidos e os de Stabellini (2008), pode-se concluir que:

1) o silenciamento de XIST é facilitado em células transformadas, que se dividem mais do que as não-transformadas. Essa hipótese vai ao encontro do proposto por Motoba e colaboradores (2011), que sugerem que, pelo RNA de Xist ser nuclear, o silenciamento de Xist via RNAi deveria ocorrer durante a metáfase;

2) XIST não tem função na manutenção da ICX em células humanas. Esta afirmativa, entretanto, pode ser contestada pelo fato de não se observar mudança na localização do RNA de XIST após silenciamento; por esta razão, somente uma alteração significativa, que abolisse a associação do RNA de XIST com o Xi, poderia responder se XIST participa da manutenção da ICX.

\section{Sistema de indução de expressão com doxiciclina}

Em nossos experimentos, a doxiciclina teve impacto na expressão de outros genes, o que inpossibilita a compreensão dos resultados obtidos. Foi com surpresa que nos demos conta deste fato, pois o sistema de indução de expressão completamente reversível controlado por tetraciclina/doxiciclina (sistema tet - Gossen \& Bujard, 1992) é amplamente utilizado em pesquisa.

A expressão de shRNAs regulada pelo sistema tet já foi usada com sucesso para silenciamento gênico temporário em sistemas in vitro (van de Wetering et al., 2003; 
Wiznerowicz \& Trono, 2003; Berger et al., 2010). Partindo de várias evidências experimentais, podemos concluir que o fenômeno observado pode ser específico das células GM135-Tel.

$\mathrm{O}$ vetor pTRIPZ possui dois componentes principais que promovem a indução: um elemento responsivo à tetraciclina (do inglês tetracycline responsive element TRE) e um elemento transativador. O TRE é modificado de seu estado primitivo, e consiste de uma sequência de operons fundidos ao promotor mínimo CMV (de citomegalovírus), que possui uma reduzida atividade basal. O transativador rtTA3 (reverse tetracycline transactivator 3) liga-se e ativa a expressão a partir do promotor TRE na presença de doxiciclina.

Ao contrário da versão original do transativador de tetraciclina, o rtTA3 é modificado para se ligar na presença de doxiciclina, e não na sua ausência. Além disso, há três mutações dentro do transativador que aumentam sua sensibilidade a doxiciclina em até 25 vezes (Das et al., 2004).

Em nossos experimentos, vários problemas foram observados com o uso dos vetores indutíveis. Um deles diz respeito ao controle da expressão dos shRNAs, pois fibroblastos transduzidos com pTRIPZ-XIST exibiram os maiores níveis de silenciamento do gene (40\%), sugerindo que o sistema de indução Tet-On não funciona corretamente, pelo menos o desenvolvido pela empresa fornecedora dos vetores. Vale dizer que as células transduzidas sem indução não expressam RFP, o que indica que o elemento responsivo a tetraciclina/doxiciclina (TRE) dirige a expressão de RFP, mas não a do shRNA.

De qualquer maneira, tanto a transdução com o vetor não indutível pGIPZ-XIST quanto a com o vetor indutível pTRIPZ-XIST não ocasionou alterações no perfil de 
expressão de genes submetidos à ICX nas células transduzidas; acreditamos que isso se deva a baixa eficiência de silenciamento de XIST alcançados.

Entretanto, a eficácia do silenciamento é medida com base na expressão de genes de controle endógenos, cuja expressão foi comprometida após exposição à doxiciclina. Até o momento, não se tem descrição deste efeito da doxiciclina em células de mamíferos.

A premissa desta investigação foi usar um vetor indutível para expressão do shRNAs contra XIST, uma vez que Stabellini (2008) teve dificuldades em silenciar o gene em células GM135-Tel usando um vetor de expressão convencional (pRETROSUPER). Uma das hipóteses levantadas pela pesquisadora foi que, neste modelo celular, uma queda representativa em XIST comprometeria a viabilidade celular.

Este trabalho conseguiu diminuir a expressão de XIST em até $40 \%$ na mesma linhagem, e não foram observadas mudanças na taxa de crescimento das células transduzidas. Talvez uma queda mais significativa na expressão de XIST seja mesmo deletéria nas células GM135-Tel, e por esta razão deve-se repensar uma nova estratégia para silenciar o gene.

Stabellini (2008) teve dificuldade em transduzir os fibroblastos GM135-Tel com vetores de expressão de shRNA. Uma análise realizada em nosso laboratório, comparando as eficiências de transdução para expressão de GFP entre diversas células, concluímos que somente $6 \%$ das células GM135 expressavam GFP. A seleção com puromicina enriquece a cultura com células onde o vetor foi inserido; o uso de vetores indutíveis, por sua vez, fornece um controle temporal de expressão dos shRNAs. Apesar de a expressão dos vetores ter sido confirmada em todos os casos pela observação de células RFP e GFP positivas, não houve diminuição significativa nos transcritos de XIST e SMCHD1. Sugere-se que o uso de doxiciclina pode ter alterado a expressão de 
outros genes, e que as sequências-alvo também não foram eficazes para promover knockdown.

Berger e colaboradores (2010) afirmam que a atividade residual de genes alvo é uma particularidade intrínseca do silenciamento de siRNAs, e pode ser a maior limitação do uso de inativação gênica mediada por RNAi. Além disso, pode haver um risco de competição entre RNAis exógenos e endógenos pela maquinaria de silenciamento, que pode ser deletéria ao metabolismo celular. Todos estes fatores precisam ser levados em consideração quando analisamos os resultados observados.

Por fim, Chan e colaboradores (2011) identificaram recentemente 32 proteínas envolvidas na manutenção da ICX em camundongos; os autores partiram de uma mistura contendo milhares de vetores para produção shRNAs tendo como alvo diversos genes, provocando silenciamento gênico global mas específico. Em nosso laboratório, pretendemos utilizar ferramentas robustas semelhantes com o intuito de saber quais são as proteínas ou ncRNAs fundamentais para a manutenção da ICX em células humanas. 
Capítulo IV

Conclusões Gerais 
A inativação do cromossomo $\mathrm{X}$ é o fenômeno epigenético que garante $\mathrm{o}$ equilíbrio dos produtos gênicos ligados ao $\mathrm{X}$ entre machos em fêmeas de mamíferos. É importante que o processo seja estudado em nossa espécie, uma vez que a grande maioria dos trabalhos abordou a questão em modelos murinos. Este trabalho teve como objetivos principais avaliar o status de ICX em linhagens de hESCs, e investigar a manutenção da ICX em células somáticas humanas normais.

Nossa investigação mostrou que há uma tendência das hESCs iniciarem a ICX in vitro, e que isto talvez possa ser determinado pelas atuais condições de cultivo. Concentrações fisiológicas de $\mathrm{O}_{2}$ foram relacionadas a um caráter epigenético mais imaturo das células, porém não impediram o início da ICX em hESCs derivadas em nosso laboratório.

Acredita-se que as hESCs encontram-se num estágio mais tardio de desenvolvimento do que as mESCs, estas últimas sendo classificadas como mais “imaturas". Além disso, é possível que o estabelecimento da ICX em humanos ocorra em momento anterior, em relação ao camundongo, do desenvolvimento embrionário. Nesse sentido, é importante destacar que restam muitas dúvidas a respeito do status da ICX em embriões humanos: se as células da MCI humana realmente estão em fase préICX e ainda não estabeleceram a ICX (como ocorre em camundongos), as atuais condições de cultivo das hESCs de alguma maneira conferem vantagem proliferativa às células que já inativaram um dos cromossomos X. Novas investigações poderão de fato esclarecer se as hESCs podem refletir as condições epigenéticas encontradas in vivo.

A função de XIST, SMCHD1 e DNMT1, fatores já associados à manutenção da ICX em camundongos, foi investigada em células humanas normais. Para tal, procurouse diminuir a expressão dos três genes por silenciamento pós-transcricional via interferência por RNA (RNAi). A análise do silenciamento dos genes XIST e SMCHD1 
foi inconclusiva, pois a doxiciclina, indutora da expressão dos shRNAs nos fibroblastos, causou alteração na expressão dos genes normalizadores endógenos utilizados. Não são conhecidos relatos similares sobre o efeito desta droga em células humanas. Experimentos utilizando sistemas alternativos de inativação gênica serão futuramente realizados para se estudar o papel destes fatores na manutenção da ICX humana.

Usando a mesma estratégia (RNAi) e tratamento com ácido valproico, pode-se diminuir em até $70 \%$ os níveis do transcrito de DNMT1, com correspondente diminuição nos níveis de metilação global. A desmetilação provocou reativação do alelo reprimido de $M A O A$ no Xi, mas não causou mudança no padrão de expressão de genes "imprintados" e nem em outros genes submetidos à ICX. A reativação do alelo inativado de $M A O A$ indica que o gene pode ser mais suscetível às perturbações epigenéticas causadas. Além disso, sugere-se que o controle da expressão gênica é particular a cada região do cromossomo Xi. Neste sentido, elementos isoladores podem estar envolvidos no fenômeno observado, uma vez que um sítio de ligação para CTCF já foi descrito próximo ao gene $M A O A$. 


\section{RESUMO}

Em fêmeas de mamíferos, um dos cromossomos $\mathrm{X}$ é inativado proporcionando compensação de dose entre os produtos gênicos de machos e fêmeas. A inativação do cromossomo X (ICX) ocorre no embrião em desenvolvimento, e se caracteriza pela aquisição de marcas heterocromáticas no cromossomo $\mathrm{X}$ inativado $(\mathrm{Xi})$, que são mantidas nas células somáticas ao longo das divisões celulares.

O melhor modelo para estudo do início da ICX são as células-tronco embrionárias femininas. Provenientes da massa celular interna de blastocistos, elas representam um embrião em desenvolvimento e possuem os dois $\mathrm{X}$ ativos; a diferenciação das células promove a ICX in vitro, o que permite a identificação dos fatores e mecanismos moleculares envolvidos. A derivação de linhagens de célulastronco embrionárias humanas (human embryonic stem cells - hESCs) em 1998 permitiu novas possibilidades de estudo da ICX, pois a maioria dos trabalhos procurou esclarecer o mecanismo da ICX no modelo murino. Tradicionalmente, a manutenção da ICX em humanos tem sido investigada em células somáticas híbridas ou transformadas; porém, sabe-se que estas não representam um contexto celular natural.

Assim, o presente trabalho teve como objetivos principais explorar a potencialidade de hESCs no estudo do início da ICX, e ainda investigar a função de três fatores na manutenção da ICX em células humanas imortalizadas: DNMT1 (enzima responsável pela manutenção da metilação do DNA), SMCHD1 (proteína da família de coesinas/condensinas), e XIST (um RNA não-codificador que inicia o processo de heterocromatinização do futuro Xi) foram selecionados para este estudo, uma vez que todos participam da manutenção da ICX em camundongos. 
Até o momento foram derivadas em nosso laboratório quatro linhagens de hESCs, as primeiras da América Latina. A caracterização das linhagens mostrou que, apesar de se manterem indiferenciadas, as hESCs femininas encontram-se em estágio pós-ICX, pois mesmo indiferenciadas já apresentam um dos X inativado. Nossos dados indicam que, submetidas às atuais condições de cultivo, as hESCs não são bons modelos para o estudo do início da ICX, e é possível que a inativação de um cromossomo X durante o cultivo confira alguma vantagem seletiva às células.

A estratégia utilizada no estudo da manutenção da ICX foi o silenciamento dos três genes por interferência de RNA (RNAi). Não foi possível diminuir significativamente a expressão dos genes XIST e SMCHD1. Porém, o silenciamento de DNMT1 foi expressivo, e em resposta foi observada reativação do gene MAOA, localizado no cromossomo $\mathrm{X}$ e submetido à inativação. Apesar de nossas análises mostrarem que os efeitos da diminuição de DNMT1 foram restritos ao gene MAOA, estes resultados sugerem a existência de diferentes hierarquias de controle epigenético dos genes submetidos à ICX em células humanas. 
In female mammals, one of the $\mathrm{X}$ chromosomes is inactivated to achieve dosage compensation between males and females. The $\mathrm{X}$ chromosome inactivation $(\mathrm{XCI})$ occurs early during embryogenesis and is characterized by the acquisition of heterochromatic features on the inactive $\mathrm{X}(\mathrm{Xi})$, which are maintained during all the subsequent cell divisions.

Embryonic stem cells are the most suitable cells to study the establishment of XCI. They are obtained from the inner cell mass (ICM) of blastocysts, and can represent a developing female embryo, possessing two active X-chromosomes; when differentiated, these cells recapitulate $\mathrm{XCI}$ in vitro, and thus one can identify XCI regulators and factors involved. The derivation of human embryonic stem cells (hESCs) in 1998 offered new possibilities to study XCI, since most of the mechanistic studies of XCI have so far been investigated in the mouse model system.

Traditionally, maintenance of XCI in humans has been addressed in somatic cell hybrids or transformed cells; however, they do not represent a natural cellular context. The main goals of the present work were to verify the potential of hESCs as models of XCI, and also to study the function of three important factors in XCI maintenance in immortalized human cells. DNMT1 (DNA-methyltransferase 1), SMCHD1 (a cohesin/condensin protein family member) and the XIST gene (a non-coding RNA which triggers $\mathrm{XCI}$ and promotes $\mathrm{X}$ heterochromatin formation on the future $\mathrm{Xi}$ ) were selected, as they are key factors in XCI maintenance in the mouse.

Until now four hESCs lines were derived in our lab. Their characterization showed that, in spite of been undifferentiated, the female hESCs have already undergone XCI. Our data suggest that, under the actual culture conditions, hESCs are 
not good models to study XCI, and it is also possible that $\mathrm{X}$ inactivation confers selective advantage to hESCs.

Knockdown by RNA interference was used to study the roles of three genes in XCI maintenance. We could not efficiently knockdown XIST or SMCHD1. However, the DNMT1 silencing was substantial, and led to the reactivation of MAOA, an X-linked gene subjected to XCI. Although the effect of DNMT1 silencing was restricted to $M A O A$, our data suggest that there are different epigenetic hierarchies to control the expression of the genes subjected to XCI in human cells. 
Adewumi, O., Aflatoonian, B., Ahrlund-Richter, L., Amit, M., Andrews, P. W., et al. Characterization of human embryonic stem cell lines by the International Stem Cell Initiative. Nat. Biotechnol., 2007. 25:803-816.

Agrelo, R., Souabni, A., Novatchkova, M., Haslinger, C., Leeb, M., et al. SATB1 defines the developmental context for gene silencing by Xist in lymphoma and embryonic cells. Dev. Cell, 2009. 16:507-516.

Alves-Silva, J., da Silva Santos, M., Guimarães, P. E., Ferreira, A. C., Bandelt, H. J., et al. The ancestry of Brazilian mtDNA lineages. Am. J. Hum. Genet., 2000. 67(2):444461.

Amanai, M., Shoji, S., Yoshida, N., Brahmajosyula, M., Perry, A. C. Injection of mammalian metaphase II oocytes with short interfering RNAs to dissect meiotic and early mitotic events. Biol. Reprod., 2006. 75:891-898.

Anderson, D. E., Losada, A., Erickson, H. P., Hirano, T. Condensin and cohesin display Different arm conformations with characteristic hinge angles. J. Cell Biol., 2002. 156(3):419-424.

Araújo, E. S. S. Estabilidade do controle epigenético em células humanas normais e transformadas. São Paulo: Universidade de São Paulo. Mestrado. 2008

Bacher, C. P., Guggiari, M., Brors, B., Augui, S., Clerc, P., et al. Transient colocalization of $\mathrm{X}$-inactivation centres accompanies the initiation of $\mathrm{X}$ inactivation. Nature Cell Biol., 2006. 8:293-299.

Bailey, J. A., Carrel, L., Chakravarti, A., Eichler, E. E. Molecular evidence for a relationship between LINE-1 elements and X chromosome inactivation: the Lyon repeat hypothesis. Proc. Natl. Acad. Sci. U.S.A., 2000. 97(12):6634-9.

Barr, M. L., Bertram, E. G. A morphological distinction between neurones of the male and female, and the behaviour of the nucleolar satellite during accelerated nucleoprotein synthesis. Nature, 1949. 163(4148):676.

Barrera, L. O., Ren. B. The transcriptional regulatory code of eukaryotic cells-insights from genome-wide analysis of chromatin organization and transcription factor binding. Curr. Opin. Cell Biol., 2006, 18:291-298.

Beard, C., Li, E., Jaenisch, R. Loss of methylation activates Xist in somatic but not in embryonic cells. Genes Dev., 1995. 6:2325-2334.

Berger, S. M., Pesold, B., Reber, S., Schönig, K., Berger, A. J., et al. Quantitative analysis of conditional gene inactivation using rationally designed, tetracyclinecontrolled miRNAs. Nucleic Acids Res., 2010. 38(17):e168. 
Bestor, T. H. The DNA methyltransferases of mammals. Hum. Mol. Genet, 2000. 9: 2395-2402.

Blewitt, M. E., Gendrel, A. V., Pang, Z., Sparrow, D. B., Whitelaw, N., et al. SmcHD1, containing a structural-maintenance-of-chromosomes hinge domain, has a critical role in X inactivation. Nat. Genet., 2008. 40(5):663-669.

Borsani, G., Tonlorenzi, R., Simmler, M. C., Dandolo, L., Arnaud, et al. Characterization of a murine gene expressed from the inactive $\mathrm{X}$ chromosome. Nature, 1991.351(6324):325-329.

Boumil R. M., Lee J. T. Forty years of decoding the silence in X-chromosome inactivation. Hum. Molec. Genet, 2001. 10:2225-2232.

Brockdorff, N. X-chromosome inactivation: closing in on proteins that bind Xist RNA. Trends Genet., 2002. 18:352-358.

Brockdorff, N., Ashworth, A., Kay, G. F., Cooper, P., Smith, S., et al. Conservation of position and exclusive expression of mouse Xist from the inactive $\mathrm{X}$ chromosome. Nature, 1991.351(6324):329-331.

Brockdorff, N., Ashworth, A., Kay, G. F., McCabe, V. M., Norris, D. P., et al. The product of the mouse Xist gene is a $15 \mathrm{~kb}$ inactive $\mathrm{X}$-specific transcript containing no conserved ORF and located in the nucleus. Cell, 1992. 71:515-526.

Brons, I. G., Smithers, L. E., Trotter, M. W., Rugg-Gunn, P., Sun, B., et al. Derivation of pluripotent epiblast stem cells from mammalian embryos. Nature, 2007. 448:191195.

Brown C. J., Hendrich, B. D., Rupert, J. L., Lafrenière, R. G., Xing, Y., et al. The human XIST gene: analysis of a $17 \mathrm{~kb}$ inactive X-specific RNA that contains conserved repeats and is highly localized within the nucleus. Cell, 1992. 71:527-642.

Brown, C. J., Ballabio, A., Rupert, J. L., Lafrenière, R. G., Grompe, M., et al. A gene from the region of the human $\mathrm{X}$ inactivation center is expressed exclusively from the inactive X chromosome. Nature, 1991. 349:38-44.

Brown, C. J., Lafrenière, R. G., Powers, V. E., Sebastio, G., Ballabio, et al. Localization of the $X$ inactivation centre on the human $X$ chromosome in Xq13. Nature, 1991. 349: 82-84.

Brown, C. J., Willard, H. F. The human X-inactivation centre is not required for maintenance of X-chromosome inactivation. Nature, 1994. 368(6467):154-156. 
Buecker, C., Chen, H. H., Polo, J. M., Daheron, L., Bu, L., et al. A murine ESC-like state facilitates transgenesis and homologous recombination in human pluripotent stem cells. Cell Stem Cell, 2010. 6:535-546.

Carrel, L., Cottle, A. A., Goglin, K. C., Willard, H. F. A first-generation X-inactivation profile of the human X chromosome. Proc. Natl. Acad. Sci. U.S.A., 1999. 96:1444014444.

Carrel, L., Willard, H. F. X-inactivation profile reveals extensive variability in X-linked gene expression in females. Nature, 2005. 434:400-404.

Castagné, R., Rotival, M., Zeller, T., Wild, P. S., Truong, V., et al. The choice of the filtering method in microarrays affects the inference regarding dosage compensation of the active X-chromosome. PLoS One., 2011. 6(9):e23956.

Cattanach, B. M. Position effect variegation in the mouse. Genet. Res. Camb., 1974. 23:291-306.

Cattanach, B. M., Pollard, C. E., Perez, J. N. Controlling elements in the mouse Xchromosome. I. Interaction with the X-linked genes. Genet. Res., 1969. 74:223-235.

Chambers, I., Colby, D., Robertson, M., Nichols, J., Lee, S., et al. Functional expression cloning of Nanog, a pluripotency sustaining factor in embryonic stem cells. Cell, 2003. 113:643-655.

Chan, K. M., Zhang, H., Malureanu, L., van Deursen, J., Zhang, Z. Diverse factors are involved in maintaining $X$ chromosome inactivation. Proc. Natl. Acad. Sci. U.S.A., 2011. 108(40):16699-16704.

Chaumeil, J., Waters, P. D., Koina, E., Gilbert, C., Robinson, T. J., Graves, J. A. Evolution from XIST-independent to XIST-controlled X-chromosome inactivation: epigenetic modifications in distantly related mammals. PLoS One. 2011. 6(4):e19040.

Chen, T., Hevi, S., Gay, F., Tsujimoto, N., He, T., et al. Complete inactivation of DNMT1 leads to mitotic catastrophe in human cancer. Cells Nat. Genet., 2007. 39(3):391-396.

Chen, X., Xu, H., Yuan, P., Fang, F., Huss, M., et al. Integration of external signaling pathways with the core transcriptional network in embryonic stem cells. Cell, 2008. 133:1106-1117.

Choi, J. H., Min, N. Y., Park, J., Kim, J. H., Park, S. H., et al. TSA-induced DNMT1 down-regulation represses hTERT expression via recruiting CTCF into demethylated core promoter region of hTERT in HCT116. Biochem. Biophys. Res. Commun., 2010. 391(1):449-454.

Chow, J., Heard, E. X inactivation and the complexities of silencing a sex chromosome. Curr. Opin. Cell Biol., 2009. 21(3):359-366. 
Chuang, P. T., Albertson, D. G., Meyer, B. J. DPY-27: a chromosome condensation protein homolog that regulates $\mathrm{C}$. elegans dosage compensation through association with the X chromosome. Cell, 1994. 79:459-474.

Clemson, C. M., McNeil, J. A., Willard, H. F., Lawrence, J. B. XIST RNA paints the inactive $\mathrm{X}$ chromosome at interphase: evidence for a novel RNA involved in nuclear/chromosome structure. J. Cell Biol., 1996. 132:259-275.

Cooper, D. W., Johnston, P. G., Watson, J. M., Graves, J. A. M. X inactivation in marsupials and monotremes. Semin. Dev. Biol., 1993. 4:117-128.

Costanzi, C., Pehrson J. R. Histone macroH2A1 is concentrated in the inactive X chromosome of female mammals. Nature, 1998. 393:599-601.

Courtier, B., Heard, E., Avner, P. Xce haplotypes show modified methylation in a region of the active X chromosome lying 3' to Xist. Proc. Natl. Acad. Sci. U.S.A.,1995: 92(8):3531-3535.

Cowan, C.A., Klimanskaya, I., McMahon, J., Atienza, J., Witmyer, J., et al. Derivation of embryonic stem-cell lines from human blastocysts. N. Engl. J. Med. 2004. 350(13):1353-1356.

Csankovszki, G., Nagy, A., Jaenisch, R. Synergism of Xist RNA, DNA methylation, and histone hypoacetylation in maintaining $X$ chromosome inactivation. J. Cell Biol., 2001. 153(4):773-784.

Das, A. T., Zhou, X., Vink, M., Klaver, B., Verhoef, K. et al. Viral evolution as a tool to improve the tetracycline-regulated gene expression system. J. Biol. Chem., 2004. 279(18):18776-18782.

Debrand, E., Chureau, C., Arnaud, D., Avner, P., Heard, E. Functional analysis of the DXPas34 locus, a 3' regulator of Xist expression. Mol. Cell Biol, 1999. 19:8513-8525.

Deuve, J. L., Avner, P. The coupling of X-chromosome inactivation to pluripotency. Annu. Rev. Cell Dev. Biol., 2011. 27:611-629.

Disteche, C. M. Escape from X inactivation in human and mouse. Science, 1995. 11:1722.

Disteche, C. M, Filippova, G. N., Tsuchiya, K. D. Escape from X inactivation. Cytogenet. Genome Res., 2002. 99(1-4):36-43.

Donohoe, M. E., Silva, S. S., Pinter, S. F., Xu, N., Lee, J. T. The pluripotency factor Oct4 interacts with Ctcf and also controls X-chromosome pairing and counting. Nature, 2009. 460, 128-132. 
Dvash, T., Lavon, N., Fan, G. Variations of X chromosome inactivation occur in early passages of female human embryonic stem cells. PLoS One, 2010. 5(6):e11330.

Egger, G., Jeong, S., Escobar, S. G., Cortez, C. C., Li, T. W., et al. Identification of DNMT1 (DNA methyltransferase 1) hypomorphs in somatic knockouts suggests an essential role for DNMT1 in cell survival. Proc. Natl. Acad. Sci. U.S.A., 2006. 103(38):14080-14085.

Evans, M. J., Kaufman, M. H. Establishment in culture of pluripotential cells from mouse embryos. Nature, 1981. 292(5819):154-156.

Forristal, C. E., Wright, K. L., Hanley, N. A., Oreffo, R. O., Houghton, F. D. Hypoxia inducible factors regulate pluripotency and proliferation in human embryonic stem cells cultured at reduced oxygen tensions. Reproduction. 2010. 139(1):85-97.

Frost, J., Monk, D., Moschidou, D., Guillot, P. V., Stanier, P., et al. The effects of culture on genomic_imprinting_profiles in human embryonic and fetal mesenchymal stem cells. Epigenetics. 2011. 6(1):52-62.

Goto, T., Monk, M. Regulation of X-Chromosome inactivation in development in mice and human. Microbiol. Mol. Biol. Rev., 1998. 62:362-378.

Graves J. A. DNA synthesis in chromosomes of cultured leucocytes from two marsupial species. Exp. Cell Res., 1967. 46:37-57.

Greaves, I. K., Rangasamy, D., Devoy, M., Marshall Graves, J. A., Tremethick, D. J. The $\mathrm{X}$ and $\mathrm{Y}$ chromosomes assemble into H2A.Z-containing facultative heterochromatin following meiosis. Mol. Cell. Biol., 2006. 26:5394-5405.

Guang, S., Bochner, A. F., Burkhart, K. B., Burton, N., Pavelec, D. M., Kennedy, S. Small regulatory RNAs inhibit RNA polymerase II during the elongation phase of transcription. Nature, 2010. 465:1097-1101.

Guang, S., Bochner, A. F., Pavelec, D. M., Burkhart, K. B., Harding, S., et al. An Argonaute Transports siRNAs from the Cytoplasm to the Nucleus. Science, 2008. 321(5888):537-541.

Hall, L. L., Byron, M., Sakai, K., Carrel, L., Willard, H. F., Lawrence, J. B. An ectopic human XIST gene can induce chromosome inactivation in postdifferentiation human HT-1080 cells. Proc. Natl. Acad. Sci. U.S.A., 2002. 99(13):8677-8682.

Hall, L. L., Lawrence, J. B. The cell biology of a novel chromosomal RNA: chromosome painting by XIST/Xist RNA initiates a remodeling cascade. Semin. Cell Dev. Biol., 2003. 14:369-378. 
Hanna, J., Cheng, A. W., Saha, K., Kim, J., Lengner, C. J., et al. Human embryonic stem cells with biological and epigenetic characteristics similar to those of mouse ESCs. Proc. Natl. Acad. Sci. U.S.A., 2010. 107(20):9222-9227.

Hansen, R. S., Stöger, R., Wijmenga, C., Stanek, A. M., Canfield, T. K., et al. Escape from gene silencing in ICF syndrome: evidence for advanced replication time as a major determinant. Hum. Mol. Genet., 2000. 9:2575-2587.

Heard, E., Mongelard, F., Arnaud, D., Avner, P. Xist yeast artificial chromosome transgenes function as X-inactivation centers only in multicopy arrays and not as single copies. Mol. Cell. Biol., 1999. 19:3156-3166.

Heard, E., Rougeulle, C., Arnaud, D., Avner, P., Allis, C. D., et al. Methylation of histone $\mathrm{H} 3$ at Lys-9 is an early mark on the $\mathrm{X}$ chromosome during $\mathrm{X}$ inactivation. Cell, 2001. 107:727-738.

Hellman, A., Chess, A. Gene body-specific methylation on the active X chromosome. Science, 2007. 315:1141-1143.

Hermann, A., Gowher, H., Jeltsch, A. Biochemistry and biology of mammalian DNA methyltransferases. Cell. Mol. Life Sci., 2004. 61(19-20):2571-2587.

Hoffman, L. M., Hall, L., Batten, J. L., Young, H., Pardasani, D., et al. X-inactivation status varies in human embryonic stem cell lines. Stem Cells, 2005. 23(10):1468-1478.

Holliday, R., Pugh, J. E. DNA Modification mechanisms and gene activity during development. Science, 1975. 187: 226-232.

Hore, T. A., Koina, E., Wakefield, M. J., Marshall Graves, J. A. The region homologous to the X-chromosome inactivation centre has been disrupted in marsupial and monotreme mammals. Chromosome Res., 2007. 15:147-161.

Huynh, K. D., Lee, J. T. Inheritance of a pre-inactivated paternal X chromosome in early mouse embryos. Nature, 2003. 426:857-862.

Inoue, K., Kohda, T., Sugimoto, M., Sado, T., Ogonuki, N., Impeding Xist expression from the active $\mathrm{X}$ chromosome improves mouse somatic cell nuclear transfer. Science, 2010. 330(6003):496-499.

Jenuwein, T., Allis, C. D. Translating the histone code. Science, 2001. 293:1074-1080.

Jeppesen P. \& Turner B. The inactive X chromosome in female Mammals is distinguished by a lack of histone $\mathrm{H} 4$ acetylation, a cytogenetic marker for gene expression. Cell, 1993. 74: p. 281 - 289.

Johnston, P. G., Cattanach, B. M. Controlling elements in the mouse. IV. Evidence of non-random X-inactivation. Genet. Res., 1981. 37:151-160. 
Kanno, T. Bucher, E., Daxinger, L., Huettel, B., Böhmdorfer, G., et al. A structuralmaintenance-of-chromosomes hinge domain-containing protein is required for RNAdirected DNA methylation. Nat. Genet., 2008. 40(5):670-675.

Kay, G. F., Barton, S. C., Surani, M. A., Rastan, S. Imprinting and X chromosome counting mechanisms determine Xist expression in early mouse development. Cell, 1994. 77:639-650.

Ketting, R. F. The many faces of RNAi. Dev. Cell, 2011. 20(2):148-161.

Kim, J., Chu, J., Shen, X,, Wang, J., Orkin, S. H. An extended transcriptional network for pluripotency of embryonic stem cells. Cell, 2008. 132:1049-1061.

Kim, K. P., Thurston, A., Mummery, C., Ward-van Oostwaard, D., Priddle, H., et al. Gene-specific vulnerability to imprinting variability in human embryonic stem cell lines. Genome Res., 2007. (12):1731-1742.

Lee, J. T., Davidow, L. S., Warshawsky, D. Tsix, a gene antisense to Xist at the Xinactivation centre. Nat. Genet., 1999. 21:400-404.

Lee, J. T. Gracefully ageing at 50, X-chromosome_inactivation becomes a paradigm for RNA and chromatin control. Nat. Rev. Mol. Cell Biol., 2011. 12(12):815-826.

Lee, J. T. Lessons from X-chromosome inactivation: long ncRNA as guides and tethers to the epigenome. Genes Dev., 2009. 23:1831-1842.

Lee, J. T., Lu, N. Targeted mutagenesis of Tsix leads to nonrandom X inactivation. Cell, 1999. 99: 47-57.

Lee, J. T., Strauss, W. M., Dausman, J. A., Jaenisch, R. A. 450 kb transgene displays properties of the mammalian X-inactivation center. Cell, 1996. 86:83-94.

Lengner, C. J., Gimelbrant, A. A., Erwin, J. A., Cheng, A. W., Guenther, M. G., et al. Derivation of pre-X inactivation human embryonic stem cells under physiological oxygen concentrations. Cell, 2010.141(5):872-883.

Li, E., Beard, C., Jaenisch, R. Role for DNA methylation in genomic imprinting. Nature, 1993. 366:362-365.

Li, E., Bestor, T. H., Jaenisch, R. Targeted mutation of the DNA methyltransferase gene results in embryonic lethality. Cell ,1992. 69:915-926.

Li, S. S.,Yu, S. L., Singh, S. Epigenetic states and expression of imprinted genes in human embryonic stem cells. World J. Stem Cells, 2010. 2(4):97-102. 
Lifschytz, E., Lindsley, D. L. The role of X-chromosome inactivation during spermatogenesis. Proc. Natl. Acad. Sci. U.S.A., 1972. 69:182-186.

Lin, H., Gupta, V., Vermilyea, M. D., Falciani, F., Lee, J. T., et al. Dosage compensation in the mouse balances upregulation and silencing of X-linked genes. PLoS Biol., 2007. 5:e326.

Loebel, D. A., Johnston, P. G. Methylation analysis of a marsupial X-linked CpG island by bisulfite genomic sequencing. Genome Res., 1996. 6:114-123.

Loughery, J. E., Dunne, P. D., O'Neill, K. M., Meehan, R. R., McDaid, J. R., Walsh, C. P. DNMT1 deficiency triggers mismatch repair defects in human cells through depletion of repair protein levels in a process involving the DNA damage response. Hum. Mol. Genet., 2011. 20(16):3241-3255.

Ludwig, T. E., Levenstein, M. E., Jones, J. M., Berggren, W. T., Mitchen, E. R., et al. Derivation of human embryonic stem cells in defined conditions. Nat. Biotechnol., 2006. 24(2):185-187.

Lyon, M. F. Gene action in the $\mathrm{X}$ chromosome of the mouse (Mus musculus L.). Nature, 1961. 190:372-373.

Lyon, M. F. Sex chromatin and gene action in the mammalian X-chromosome. Am. J. Hum. Genet., 1962. 14:135-148.

Lyon, M. F. Possible mechanisms of X chromosome inactivation. Nature New Biol., 1971. 232:229-232.

Lyon, M. F. X-chromosome inactivation: a repeat hypothesis. Cytogenet. Cell Genet., 1998;80(1-4):133-137.

Mak, W., Nesterova, T. B., de Napoles, M., Appanah, R., Yamanaka, S., et al. Reactivation of the paternal X chromosome in early mouse embryos. Science, 2004. 303:666-669.

Marahrens, Y., Panning, B., Dausman, J., Strauss, W., Jaenisch, R. Xist-deficient mice are defective in dosage compensation but not spermatogenesis. Genes Dev., 1997. 11: $156-166$.

Martin, G. R. Isolation of a pluripotent cell line from early_mouse_embryos cultured in medium conditioned by teratocarcinoma_stem_cells. Proc. Natl. Acad. Sci. U.S.A., 1981. 78(12):7634-7638.

Masui, S., Nakatake, Y., Toyooka, Y., Shimosato, D., Yagi, R., et al. Pluripotency governed by Sox2 via regulation of Oct3/4 expression in mouse embryonic stem cells. Nat. Cell Biol., 2007. 9:625-635.

Matoba, S., Inoue, K., Kohda, T., Sugimoto, M., Mizutani, E., et al. RNAi-mediated knockdown of Xist can rescue the impaired postimplantation development of cloned mouse embryos. Proc. Natl. Acad. Sci. U.S.A., 2011.108(51):20621-20626. 
Mattei, M. G., Mattei, J. F., Vidal, I., Giraud, F. Structural anomalies of the X chromosome and inactivation center. Hum. Genet., 1981. 56:401-408.

Migeon, B. R. X-linked hypoxanthine-guanine phosphoribosyl transferase deficiency: detection of heterozygotes by selective medium. Biochem, Genet., 1970. 4(3):377-383. Migeon, B. R. X chromosome inactivation: theme and variations. Cytogenet. Genome Res. 2002. 99(1-4):8-16.

Migeon, B. R., Chowdhury, A. K., Dunston, J. A., McIntosh, I. Identification of_TSIX, encoding an RNA antisense to human XIST, reveals differences from its murine counterpart: implications for X inactivation. Am. J. Hum. Genet., 2001. 69(5):951960 .

Migeon, B. R., Kazi, E., Haisley-Royster, C., Hu, J., Reeves, R., et al. Human X inactivation center induces random $\mathrm{X}$ chromosome inactivation in male transgenic mice. Genomics, 1999. 59:113-121.

Moreira de Mello, J. C., de Araújo, E. S., Stabellini, R., Fraga, A. M., de Souza, J. E., et al. Random $\mathrm{X}$ inactivation and extensive mosaicism in human placenta revealed by analysis of allele-specific gene expression along the X chromosome. PLoS One., 2010. 5(6):e10947.

Morey, C., Avner, P. The demoiselle of X-inactivation: 50 years old and as trendy and mesmerising as ever. PLoS Genet., 2011. (7):e1002212.

Namekawa, S. H., Payer, B., Huynh, K. D., Jaenisch, R., Lee, J. T. Two-step imprinted $\mathrm{X}$ inactivation: repeat versus genic silencing in the mouse. Mol. Cell. Biol., 2010. 30: 3187-3205.

Navarro, P., Chambers, I., Karwacki-Neisius, V., Chureau, C., Morey, C., et al. Molecular coupling of Xist regulation and pluripotency. Science, 2008. 321:1693-1695.

Navarro, P., Moffat, M., Mullin, N. P., Chambers, I. The X-inactivation transactivator Rnf12 is negatively regulated by pluripotency factors in embryonic stem cells. Hum. Genet., 2011. 130(2):255-264.

Nguyen, D. K., Disteche, C. M. Dosage compensation of the active X chromosome in mammals. Nat. Genet., 2006. 38(1):47-53.

Niwa, H., Miyazaki, J-I., Smith, A. G. Quantitative expression of Oct-3/4 defines differentiation, dedifferentiation or self-renewal of ES cells. Nat. Genet., 2000. 24:37276.

Nora, E. P., Heard, E. Chromatin structure and nuclear organization dynamics during Xchromosome inactivation. Cold Spring Harb. Symp. Quant. Biol., 2010. 75:333-344.

Nordquist, N., Oreland, L. Monoallelic expression of MAOA in skin fibroblasts. Biochem. Biophys. Res. Commun., 2006. 348:763-767. 
Nyhan, W. L., Bakay, B., Connor, J. D., Marks, J. K. Keele, D. K. Hemizygous expression of glucose-6-phosphate dehydrogenase in erythrocytes of heterozygotes for the Lesch-Nyhan syndrome. Proc. Natl. Acad. Sci., U.S.A., 1970. 65:214-218.

Oda, M., Yamagiwa, A., Yamamoto, S., Nakayama, T., Tsumura, A., et al. DNA methylation regulates long-range gene silencing of an X-linked homeobox gene cluster in a lineage-specific manner. Genes Dev., 2006. 20:3382-3394.

Ohno, S. Evolution of sex chromosomes in mammals. Annu. Rev. Genet., 1969. 3:495524.

Ohno, S., Hauschka, T. S. Allocycly of the X-chromosome in tumors and normal tissues. Cancer Res., 1960. 20:541-545.

Okamoto, I., Otte, A. P., Allis, C. D., Reinberg, D., Heard, E. Epigenetic dynamics of imprinted X inactivation during early mouse development. Science, 2004. 303:644-649.

Okamoto, I., Patrat, C., Thépot, D., Peynot, N., Fauque, P., et al. Eutherian mammals use diverse strategies to initiate $\mathrm{X}$-chromosome inactivation during development. Nature, 2011. 472(7343):370-374.

Orkin, S. H., Hochedlinger, K. Chromatin connections to pluripotency and cellular reprogramming. Cell, 2011.145(6):835-850.

Panning, B., Jaenisch R. DNA hypomethylation can activate Xist expression and silence X-linked genes. Genes Dev., 1996. 10:1991-2002.

Patrat, C., Okamoto, I., Diabangouaya, P., Vialon, V., Le Baccon. P.,et al. Dynamic changes in paternal X-chromosome activity during imprinted X-chromosome inactivation in mice. Proc. Natl. Acad. Sci. U.S.A., 2009. 13:5198-5203.

Payer, B., Lee, J. T. X chromosome dosage compensation: how mammals keep the balance. Annu. Rev. Genet., 2008. 42:733-772.

Penny, G. D, Kay, G. F, Sheardown, S. A, Rastan, S., Brockdorff, N. Requirement for Xist in X chromosome inactivation. Nature, 1996. 379:131-137.

Plath, K., Fang, J., Mlynarczyk-Evans, S. K., Cao, R., Worringer, K. A., et al. Role of histone H3 lysine 27 methylation in X inactivation. Science, 2003. 300:131-135.

Prokhorova, T. A., Harkness, L. M., Frandsen, U., Ditzel, N., Schrøder, H. D., et al. Teratoma formation by human embryonic stem cells is site dependent and enhanced by the presence of matrigel. Stem Cells Dev., 2009. 18(1):47-54.

Rastan, S. Non-random X-chromosome inactivation in mouse X:autosome translocation embryos-location of the inactivation centre. J. Embryol. Exp. Morphol., 1983. 78:122. 
Rhee, I., Bachman, K. E., Park, B. H., Jair, K.-W., Yen, R.-W.C., et al. DNMT1 and DNMT3b cooperate to silence genes in human cancer cells. Nature, 2002. 416:552556.

Rhee, I., Jair, K-W., Yen, R-WC., Lengauer, C., Herman, J. G., et al. CpG methylation is maintained in human cancer cells lacking DNMT1. Nature, 2000. 404: 1003-1007.

Ross, M. T., Grafham, D. V., Coffey, A. J., Sherer, S., McLay, K., et al. The DNA sequence of the human X chromosome. Nature, 2005. 434:325-337.

Rugg-Gunn, P. J., Ferguson-Smith, A. C., Pedersen, R. A. Status of genomic imprinting in human embryonic stem cells as revealed by a large cohort of independently derived and maintained lines. Hum. Mol. Genet., 2007. 2:R243-251.

Russell, L. B. Mammalian X-chromosome action: inactivation limited in spread and in region of origin. Science, 1963. 740:976-978.

Russell, L. B., Cacheiro, N. L. A. The use of mouse X-autosome translocations in the study of X-inactivation pathways and non-randomness. In: Russell, L. B. (editor). Genetic Mosaics and Chimaeras in Mammals, New York and London: Plenum Press, 1978.

Russell, L. B., Montgomery, C. S. The use of X-autosome translocations in locating the X-chromosome inactivation centre. Genetics, 1965. 52: 470-471.

Sakabe, N. J., Nobrega, M. A. Genome-wide maps of transcription regulatory elements. Wiley Interdiscip. Rev. Syst. Biol. Med., 2010. 2(4):422-437.

Santos, F. R., Pena, S. D., Epplen, J. T. Genetic and population study of a Y-linked tetranucleotide repeat DNA polymorphism with a simple non-isotopic technic. Hum. Genet., 1993. 90:655-656.

Savarese, F., Dávila, A., Nechanitzky, R., De La Rosa-Velazquez, I., Pereira, C.F., et al. Satb1 and Satb2 regulate embryonic stem cell differentiation and Nanog expression. Genes Dev., 2009. 23:2625-2638.

Seif, I., De Maeyer, E. Knockout corner: knockout mice for monoamine oxidase A. Int. J.Neuropsychopharmacol., 1999. 2:241-224.

Sharman, G. B. Late DNA replication in the paternally derived X chromosome of female kangaroos. Nature, 1971. 230:231-232.

Shen, Y., Matsuno, Y., Fouse, S. D., Rao, N., Root, S., et al. X-inactivation in female human embryonic stem cells is in a nonrandom pattern and prone to epigenetic alterations. Proc. Natl. Acad. Sci. U.S.A., 2008. 105(12):4709-4714.

Shih, J. C., Thompson, R. F. Monoamine oxidase in neuropsychiatry and behavior. Am. J. Hum.Genet., 1999. 65:593-598. 
Silva, J., Mak, W., Zvetkova, I., Appanah, R., Nesterova, et al. Establishment of histone h3 methylation on the inactive X chromosome requires transient recruitment of EedEnx1 polycomb group complexes. Dev. Cell, 2003. 4:481-495.

Silva, S. S., Rowntree, R. K., Mekhoubad, S., Lee, J. T. X-chromosome inactivation and epigenetic fluidity in human embryonic stem cells. Proc. Natl. Acad. Sci., U.S.A., 2008. 105(12):4820-4825.

Smith, K. P., Byron, M., Clemson, C. M., Lawrence, J. B. Ubiquitinated proteins including $\mathrm{uH} 2 \mathrm{~A}$ on the human and mouse inactive $\mathrm{X}$ chromosome: enrichment in gene rich bands. Chromosoma, 2004. 113(6):324-335.

Stabellini, R. Análise funcional dos genes XIST e DNMT1 na manutenção do processo de inativação do cromossomo $X$ humano através do silenciamento gênico por RNAi. São Paulo: Universidade de São Paulo. Doutorado. 2008.

Stabellini, R., de Mello, J. C., Hernandes, L. M., Pereira, L. V. MAOA and GYG2 are submitted to X chromosome inactivation in human fibroblasts. Epigenetics, 2009. 4(6):388-393.

Sun, B., Ito, M., Mendjan, S., Ito, Y., Brons, I. G., et al. Status of genomic imprinting in epigenetically distinct pluripotent stem cells. Stem Cells, 2011. 30(2):161-168.

Takagi, N., Sasaki, M. Preferential inactivation of the paternally derived X chromosome in the extraembryonic membranes of the mouse. Nature, 1975. 256(5519):640-642.

Tanasijevic, B., Daí, B., Ezashi, T., Livingston, K., Roberts, R. M., et al. Progressive accumulation of epigenetic heterogeneity during human ES cell culture. Epigenetics, 2009. 4(5):330-338.

Thomson, J. A., Itskovitz-Eldor, J., Shapiro, S. S., Waknitz, M. A., Swiergiel, J. J, et al. Embryonic stem cell lines derived from human blastocysts. Science, 1998. 282(5391):1145-1147.

Tinker, A. V., Brown, C. J. Induction of XIST expression from the human active X chromosome in mouse/human somatic cell hybrids by DNA demethylation. Nucleic Acids Res., 1998. 26(12):2935-2940.

Tjio, H. J., Östergren, G. The chromosomes of primary mammary carcinomas in milk virus strains of the mouse. Hereditas, 1958. 44:451-465.

Van de Wetering, M., Oving, I., Muncan, V., Pon Fong, M. T., Brantjes, H., et al. Specific inhibition of gene expression using a stably integrated, inducible smallinterfering-RNA vector. EMBO Rep., 2003. 4:609-615.

Van den Berg I. M., Laven, J. S., Stevens, M., Jonkers, I., Galjaard, R. J., et al. X chromosome inactivation is initiated in human preimplantation embryos. Am. J. Hum. Genet., 2009. 84(6):771-779. 
VandeBerg J. L., Robinson, E. S., Samollow, P. B., Johnston, P. G. X-linked gene expression and X-chromosome inactivation: marsupials, mouse, and man compared. Isozymes Curr. Top Biol. Med. Res., 1987. 15:225-253.

Vandesompele, J., De Preter, K., Pattyn, F., Poppe, B., Van Roy, N. et al. Accurate normalization of real-time quantitative RT-PCR data by geometric averaging of multiple internal reference genes. Genome Biol., 2002. 3(7):reserach0034.

Vasques, L. R. Análise functional do gene DNMT1 no controle da expressão do gene XIST e na manutenção do estado inativo do cromossomo X-inativo (Xi). São Paulo: Universidade de São Paulo. Doutorado. 2003.

Vasques, L. R., Klöckner, M. N., Pereira, L. V. X-Chromosome inactivation: how human are mice? Cytogenet. Genome Res., 2002. 99:30-35.

Vasques, L. R., Pereira L. V. Allele-specific X-linked gene activity in normal human cells assayed by expressed single nucleotide polymorphisms (cSNPs). DNA Res., 2001. 8:173-177.

Vasques, L. R., Stabellini, R., Xue, F., Tian, X. C., Soukoyan, M., Pereira, LV. XIST repression in the absence of DNMT1 and DNMT3B. DNA Res., 2005. 12:373-378.

Vines, G. Mary Lyon: quiet battler. Curr. Biol., 1997. 7:R269-R270.

Wake, N., Takagi, N., Sasaki, M. Non-random inactivation of X chromosome in the rat yolk sac. Nature, 1976. 262(5569):580-581.

Walsh, C. P., Chaillet, J. R., Bestor, T. H. Transcription of IAP endogenous retroviruses is constrained by cytosine methylation. Nat.Genet., 1998. 20:116-117.

Weber, M., Davies, J. J., Wittig, D., Oakeley, E. J., Haase, M., et al. Chromosome-wide and promoter-specific analyses identify sites of differential DNA methylation in normal and transformed human cells. Nat. Genet., 2005, 37:853-862.

West, J. D., Frels, W. I., Chapman V. M., Papaioannou, V. E. Preferential expression of the maternally derived X chromosome in the mouse yolk sac. Cell, 1977. 12(4):873882.

Wikman, H., Kettunen, E., Seppanen, J. K., Karjalainen, A., Hollmen, J., et al.. Identification of differentially expressed genes in pulmonary adenocarcinoma by using cDNA array. Oncogene, 2002. 21(37):5804-5813.

Wiznerowicz, M., Trono, D. Conditional suppression of cellular genes: lentivirus vector-mediated drug-inducible RNA interference. J. Virol., 2003. 77:8957-8961.

Wutz, A. Xist function: bridging chromatin and stem cells. Trends Genet., 2007. 23(9):457-464. 
Wutz, A., Rasmussen, T. P., Jaenisch, R. Chromosomal silencing and localization are mediated by different domains of Xist RNA. Nat. Genet., 2002. 30:167-174.

Xiong, Y., Chen, X., Chen, Z., Wang, X., Shi, S., et al., RNA sequencing shows no dosage compensation of the active X-chromosome. Nat. Genet., 2010. 42(12):10431047.

Xu, N., Tsai, C. L., Lee, J. T. Transient homologous chromosome pairing marks the onset of X inactivation. Science, 2006. 311:1149-1152.

Xue, F., Tian, X. C., Du, F., Kubota, C., Taneja, M., et al. Aberrant patterns of X chromosome inactivation in bovine clones. Nat. Genet., 2002. 31(2):216-220.

Yang, C., Chapman, A. G., Kelsey, A. D., Minks, J., Cotton, A. M., Brown, C. J. Xchromosome inactivation: molecular mechanisms from the human perspective. Hum. Genet., 2011. 130(2):175-185.

Yoshida, Y., Takahashi, K., Okita, K., Ichisaka, T., Yamanaka, S. Hypoxia enhances the generation of induced pluripotent stem cells. Cell Stem Cell, 2009. 5:237-241.

Zhang, L. F., Huynh, K. D., Lee, J. T. Perinucleolar targeting of the inactive_X_during S phase: evidence for a role in the maintenance of silencing. Cell, 2007. 129(4):693-706.

Zhao, C., Yasui, K., Lee, C. J., Kurioka, H., Hosokawa, Y.et al. Elevated expression levels of NCOA3, TOP1, and TFAP2C in breast tumors as predictors of poor prognosis. Cancer, 2003. 98(1):18-23.

Zhao, J., Sun, B. K., Erwin, J. A., Song, J. J., Lee, J. T. Polycomb proteins targeted by a short repeat RNA to the mouse X chromosome. Science, 2008. 322:750-756.

Zhou, V. W., Goren, A., Bernstein, B. E. Charting histone modifications and the functional organization of mammalian genomes. Nat. Rev. Genet., 2011. 12(1):7-18.

Zhou, Q., Agoston, A. T., Atadia, P., Nelson, W. G., Davidson, N. E. Inhibition of histone deacetylases promotes ubiquitin-dependent proteasomal degradation of DNA methyltransferase 1 in human breast cancer cells. Mol. Cancer Res., 2008. 6(5):873883. 
AneXos 
Anexo 1: Iniciadores utilizados neste trabalho para amplificação das regiões contendo cSNPs em genes "imprintados".

\begin{tabular}{|c|c|c|c|c|c|}
\hline Gene & Localização & Iniciador Forward & Iniciador Reverse & $\begin{array}{c}\text { Tamanho do } \\
\text { Amplicon }\end{array}$ & Identificação do(s) SNP(s)* \\
\hline ATP10A & $15 q 11.2$ & 5'-GAATACCGGCCACGAAC-3' & 5'-GCAGGAAAGTGAGCAGCG-3' & $\begin{array}{l}\text { cDNA } 157 \mathrm{pb} \\
\text { DNA } 236 \mathrm{pb}\end{array}$ & $\begin{array}{l}\text { rs2076741; rs2076742; } \\
\text { rs2076743; rs2076744; } \\
\text { rs2076745 }\end{array}$ \\
\hline $\begin{array}{l}D L K 1 \\
(P E G 9)\end{array}$ & $14 q 32$ & 5'-CTGGCTTCTCAGGCAATTTC-3' & 5'-TTTCATGGACACCTTCAGGA-3' & $\begin{array}{c}\text { cDNA/DNA } \\
392 \mathrm{pb}\end{array}$ & $\begin{array}{c}\text { rs1802710; rs34429112; } \\
\text { rs2295660; rs1058009; } \\
\text { rs35339877 }\end{array}$ \\
\hline$H 19$ & $11 \mathrm{p} 15.5$ & 5'-AGCCCAACATCAAAGACACC-3' & 5'-AATGGAATGCTTGAAGGCTG-3' & $\begin{array}{l}\text { cDNA/DNA } \\
508 \mathrm{pb}\end{array}$ & $\begin{array}{l}\text { rs10840159; rs217727; } \\
\text { rs11542726; rs11542724; } \\
\text { rs3741216; rs11542723; } \\
\text { rs2839703; rs2839704; } \\
\text { rs3741219; rs11542725; } \\
\text { rs11542721 }\end{array}$ \\
\hline$I G F 2$ & $11 \mathrm{p} 15.5$ & 5'-CCTAGTCGTGGCTCTCCATC-3' & 5'-TTAAAGACAAAACCCAAGCATG-3' & $\begin{array}{c}\text { cDNA/DNA } \\
228 \mathrm{pb}\end{array}$ & rs 2585 \\
\hline MAGEL2 & $15 q 11-q 12$ & 5'-CCCCGCTAATAGGTGTAGCA-3' & 5'-AACGTTCAAAGAACAACCGATTA-3' & $\begin{array}{l}\text { cDNA/DNA } \\
375 \mathrm{pb}\end{array}$ & rs8920; rs10739; rs9785 \\
\hline $\begin{array}{l}\text { MEG3 } \\
\text { (GTL2) }\end{array}$ & $14 q 32$ & 5'-GTTTCTGGACTGTGGGCTGT-3' & 5'-CATTGTCAAATGTCAGAGGCA-3' & $\begin{array}{c}\text { cDNA/DNA } \\
400 \mathrm{pb}\end{array}$ & $\begin{array}{c}\text { rs1054013; rs3742393; } \\
\text { rs11160608 }\end{array}$ \\
\hline $\begin{array}{c}\text { MKRN3 } \\
(\text { ZNF127) } \\
\end{array}$ & $15 q 11-q 13$ & 5'-GGAGAACTGTCGCTATTCGC-3' & 5'-CAAACTCCCCTGGAAGCATA-3' & $\begin{array}{c}\text { cDNA/DNA } \\
420 \mathrm{pb}\end{array}$ & rs2239669; rs36072495 \\
\hline PEG10 & $7 \mathrm{q} 21.3$ & 5'-TCATTTTCCTGCCTGGTTGC-3' & 5'-GGAGCCTCTCATTCACAGC-3' & $\begin{array}{c}\text { cDNA/DNA } \\
406 \mathrm{pb}\end{array}$ & $\begin{array}{c}\text { rs13073; rs13226637; } \\
\text { rs1136429 }\end{array}$ \\
\hline SNRPN & $15 \mathrm{q} 11.2$ & 5'-TTCATGCAAAATTGTCTGCC-3' & 5'-CCCTCAGCCTTATCATACAG-3' & $\begin{array}{c}\text { cDNA/DNA } \\
171 \mathrm{pb}\end{array}$ & rs705 \\
\hline$T P 73$ & $1 \mathrm{p} 36.3$ & 5'-CCCCGCTCTTGAAGAAACTC-3' & 5'-CTTCGTTGAAGTCCCTCCC-3' & $\begin{array}{l}\text { cDNA/DNA } \\
168 \mathrm{pb}\end{array}$ & rs1801174 \\
\hline
\end{tabular}

*de acordo com o NCBI

\#iniciadores descritos por Kim e colaboradores (2007) 
Anexo 2: Iniciadores para amplificação de genes ligados ao cromossomo X, heterozigotos na posição dos cSNPs na linhagem GM135-Tel.

\begin{tabular}{|c|c|c|c|c|c|c|}
\hline Gene & Localização & Inciador Forward & Inciador Reverse & $\begin{array}{c}\text { Amplicon } \\
\text { DNA }\end{array}$ & $\begin{array}{c}\text { Amplicon } \\
\text { cDNA }\end{array}$ & $\begin{array}{c}\text { Identificação } \\
\text { do(s) } \\
\text { SNP(s)** }\end{array}$ \\
\hline$G Y G 2 *$ & Xp22.23 & 5'-CGCTGTTGAACCTTGTGCCT-3' & 5'-ACCACCATCGAGAGTCTACT-3' & $206 \mathrm{pb}$ & $206 \mathrm{pb}$ & rs211659 \\
\hline FAM16AX & $\mathrm{Xp} 22.31$ & 5'-TCTCAGAAGTCAAGCTGATGGA-3' & 5'-GCATGTAATGCCTACCTGCAT-3' & $117 \mathrm{pb}$ & $117 \mathrm{pb}$ & rs10458 \\
\hline$T B L 1 X$ & Xp22.22 & 5'- TGCTTGCGACACATCCCA-3' & 5'-GACACCATCTCTACCCCAC-3' & $147 \mathrm{pb}$ & $147 \mathrm{pb}$ & rs 7256 \\
\hline$P I G A^{*}$ & $\mathrm{Xp22.22}$ & 5'-CGACCAGTGCAAACTGACCAG-3' & 5'-AGGTTTTAGAGGCATGCCAC-3' & $255 \mathrm{pb}$ & $255 \mathrm{pb}$ & $\begin{array}{c}\text { rs11448948; } \\
\text { rs3087965 }\end{array}$ \\
\hline$Z F X^{*}$ & $\mathrm{Xp} 22.21$ & 5'-TGGCAAACCTCTGAAGTGCT-3' & 5'-ACATTATGGGGGCCAAGAAG-3' & $158 \mathrm{pb}$ & $158 \mathrm{pb}$ & rs5949242 \\
\hline TCTEIL & Xp11.4 & 5'-GCCAAAAACAAAGATCACTGC-3' & 5'-GAGAGCGGAACCATAACTCA-3' & $200 \mathrm{pb}$ & $200 \mathrm{pb}$ & rs7256 \\
\hline MAOA & Xp11.3 & 5'-AGACCAGAGCTTCCAGCAGA-3' & 5'-TCATTATGTGTGGCCAAGGA-3' & $275 \mathrm{pb}$ & $275 \mathrm{pb}$ & rs6323 \\
\hline MAOA & Xp11.3 & 5'-GTAACATTCTATTTCAACTTCAG-3' & 5'-GGGGAAAACAAGAGGTGGG-3' & $362 \mathrm{pb}$ & $362 \mathrm{pb}$ & rs3027 \\
\hline MAOA & Xp11.3 & 5'-AAATGGTCTCGGGAAGGTGA-3' & 5'-ACCGTGGCAGGAGCTTGTAT-3' & $395 \mathrm{pb}$ & $200 \mathrm{pb}$ & rs180291 \\
\hline$M A O B$ & Xp11.3 & 5'-TGGCTTAGCGTTCTGTTTCA-3' & 5'-TGTGGGCTTCAGTTTGCTC-3' & $297 \mathrm{pb}$ & $297 \mathrm{pb}$ & rs2072745 \\
\hline SUV39H1* & Xp11.23. & 5'-TTGTGCTCACCCTGGTTC-3' & 5'-GCATAGGGTTGAGGGGTGTA-3' & $292 \mathrm{pb}$ & $292 \mathrm{pb}$ & rs3373 _ \\
\hline$X I S T^{*}$ & & 5'-CAGCATGGTTGGTGACACCTAAG-3' & 5'-TGGAATGAGCAGTGTGCGAT-3' & $241 \mathrm{pb}$ & $241 \mathrm{pb}$ & rs 1894271 \\
\hline XIST & Xq13.3 & 5'-GGCATTTATTCTGACTTGGAGATG-3' & 5'-CCTGCTTATCGTAGTGGCCAG-3' & $431 \mathrm{pb}$ & $431 \mathrm{pb}$ & rs16992436 \\
\hline XIST & $\mathrm{Xq13.3}$ & 5'-GTGACACAAGGCCAACGACC-3' & 5'-GAATCAGGCTTAAAGATAAACAGGAG-3' & $369 \mathrm{pb}$ & $369 \mathrm{pb}$ & rs 16992443 \\
\hline TCEALA* & $\mathrm{Xq} 22.3$ & 5'-TGGCTCATTACCTCAAGGAG-3' & 5'-CTTGGACCTCTAGGGTAGAA-3' & $186 \mathrm{pb}$ & $186 \mathrm{pb}$ & rs11010 \\
\hline GPC4* & $\mathrm{Xq} 26.2$ & 5'-CACGTCGTTCCCATTGTATG-3' & 5'-ACCTGTTTGCAGTGACAGGA-3' & $158 \mathrm{pb}$ & $158 \mathrm{pb}$ & rs 1048369 \\
\hline
\end{tabular}

Linha tracejada indica localização do centrômero

\#de acordo com o NCBI

*iniciadores descritos por Carrel e Willard, 2005 
Anexo 3: Artigo publicado na revista Cell Transplantation em agosto de 2010. 


\title{
Establishment of a Brazilian Line of Human Embryonic Stem Cells in Defined Medium: Implications for Cell Therapy in an Ethnically Diverse Population
}

\author{
Ana M. Fraga, $* \dagger \neq$ Marina Sukoyan,§ Prithi Rajan,II Daniela Paes de Almeida Ferreira Braga,\# \\ Assumpto Iaconelli, Jr.,\# José Gonçalves Franco, Jr.,** Edson Borges, Jr.,\# and Lygia V. Pereira*†† \\ *Laboratório de Genética Molecular, Instituto de Biociências, Universidade de São Paulo, São Paulo, Brasil \\ $\nmid$ Laboratório Nacional de Células-Tronco Embrionárias (LaNCE), Instituto de Biociências, \\ Universidade de São Paulo, São Paulo, Brasil \\ ‡Instituto Nacional de Ciência e Tecnologia em Células-Tronco e Terapia Celular, Ribeirão Preto, Brasil \\ $\S$ Russian Academy of Sciences, Novosibirsk, Russia \\ IIAgni Consulting Services, San Marcos, CA, USA \\ \#Fertility and Associação Instituto Sapientiae, São Paulo, Brasil \\ **Centro de Reprodução Humana Prof. Franco Júnior, Ribeirão Preto, Brasil
}

\begin{abstract}
Pluripotent human embryonic stem (hES) cells are an important experimental tool for basic and applied research, and a potential source of different tissues for transplantation. However, one important challenge for the clinical use of these cells is the issue of immunocompatibility, which may be dealt with by the establishment of hES cell banks to attend different populations. Here we describe the derivation and characterization of a line of hES cells from the Brazilian population, named BR-1, in commercial defined medium. In contrast to the other hES cell lines established in defined medium, BR-1 maintained a stable normal karyotype as determined by genomic array analysis after 6 months in continuous culture (passage 29). To our knowledge, this is the first reported line of hES cells derived in South America. We have determined its genomic ancestry and compared the HLA-profile of BR-1 and another $22 \mathrm{hES}$ cell lines established elsewhere with those of the Brazilian population, finding they would match only $0.011 \%$ of those individuals. Our results highlight the challenges involved in hES cell banking for populations with a high degree of ethnic admixture.
\end{abstract}

Key words: Human embryonic stem cells; Brazilian population; Defined medium; Cell banking; Genetic diversity

\section{INTRODUCTION}

The pluripotency of embryonic stem (ES) cells has rendered them a potential source of tissues for transplantation. For the last two decades, this property has been demonstrated in animal models of several conditions, including diabetes [reviewed in (19)], spinal cord injury, and Parkinson's disease [reviewed in (14)]. The establishment of hES cells in 1998 (35) has increased the expectations regarding the therapeutic use of these cells in patients. However, in addition to the concerns about the tumorigenic potential of hES cells, issues regarding the immunogeneicity of tissues derived from these cells, and the standardization of production of cells as pharmacological agents may hinder their use in humans.
As for other sources of tissues and cells for transplantation, the risk of immune rejection of hES-derived cells is correlated with the presence of cell surface antigens at the major histocompatibility complex (MHC), in humans represented by the HLA (human leukocyte antigen) proteins. Thus, the higher the similarity among HLA types, the lesser the chance of rejection, increasing the likelihood of transplant survival (31). However, the genes encoding for HLA are very polymorphic in our species (34), making it extremely difficult to obtain a perfect match between donor and recipient.

A review of the literature shows that the issue of the immunogenicity of hES cell-derived tissues is still not clear. These cells express HLA-I genes, albeit in lower levels than somatic cells do (9). On the other hand, these 
pluripotent cells show imunogeneicity in mice, where immunosuppressive therapy must be employed in order to avoid rejection of hES cells by the host immune system (32).

Strategies to reduce immunogenicity of allogenic hES cell-derived grafts include the generation of patientspecific cell lines by somatic cell nuclear transfer [reviewed in (39)] or by reprogramming adult cells into a pluripotent state [induced pluripotent stem (iPS) cells] with different transcription factors [reviewed in (38)]. Although in theory these methods would circumvent the issue of immunocompatibility, the generation of autologous tissues for transplantation is in practice extremely demanding and expensive. Furthermore, current methods for generating iPS cells involve genetic modifications, which increase the risk of their therapeutic use. Finally, because patient-specific pluripotent cell lines would not be universal therapeutic agents, each cell line generated will probably be treated as a separate product, and in that case will have to go through extensive preclinical and clinical testing before being approved by the regulatory bodies for therapeutic use (7).

An alternative to reduce immunogenicity of allogenic hES cell-derived grafts is banking of MHC-compatible hES cell lines (33). It is still debatable how many genetically diverse cell lines such a bank would need in order to attend different populations. The numbers vary from hundreds $(28,33)$ to millions $(5,8)$ of lines, depending on the acceptable degree of immune mismatch, and on the genetic diversity of the population under consideration.

Equally important for regenerative therapies is the standardization of defined conditions and processes to be used in manufacturing hES cell-based therapeutic cells (i.e., culture and differentiation of the cells) (11). Although the culture of hES cells in defined medium has been reported by different groups $(24,40)$, there is only one report of the establishment of new lines of hES cells in defined medium (25). However, one of the lines was aneuploid already in early passages, while the other became aneuploid after 4-7 months in culture.

Here we describe the derivation of a new hES cell line, called BR-1, using a defined commercial medium. This hES cell line expresses markers of pluripotency, can be differentiated into tissues of the three germ layers, and presents a stable normal karyotype after 6 months of continuous culture in defined medium. We compare its HLA profile to those of a subset of the Brazilian population, and discuss the implications for hES cell-based therapy in ethnically diverse populations. To our knowledge, BR-1 is the first hES cell line derived in South America, and the characterization of its genomic ancestry raises important issues regarding hES cell banking to attend genetically admixed populations.

\section{MATERIALS AND METHODS}

\section{Establishment of hES Cell Lines}

Couples donated surplus embryos from in vitro fertilization (IVF) cycles according to the Brazilian legislation (Bio-safety Law 11.105, March 25, 2005), signing the informed consent, and with the approval of the Ethics Committee of the Instituto de Biociências of the Universidade de São Paulo. Whole embryos at blastocyst stage or mechanically dissected inner cell masses were plated on four-well plates coated with hES-certified Matrigel (BD Biosciences) and cultured with mTeSR1 defined medium (StemCell Technologies), a serum-free medium that includes high levels of growth factors like bFGF and TGF- $\beta$. No additional component was added to the medium. After $48 \mathrm{~h}$, half of the medium was changed every other day for 7-12 days. Outgrowths were mechanically passaged into new wells coated with Matrigel or mouse irradiated feeder cells (MEFs; Chemicon Millipore). After the first passage (p1), half-medium change was performed every day with mTeSR1. Colonies were mechanically passaged every 5-7 days, and after the third passage half of the cell clumps obtained from mechanical dissociation of the colonies was frozen in $90 \%$ fetal bovine serum (FBS, Hyclone) and 10\% DMSO (Sigma).

\section{Immunocytochemistry}

Cells from passages 6 and 29 were fixed and immunostained following standard protocols. Briefly, cells were fixed with $4 \%$ paraformaldehyde for $10 \mathrm{~min}$, permeabilized in $0.1 \%$ Triton X-100 solution (Sigma), and blocked in $1 \%$ fetal bovine serum (FBS; Hyclone) for $1 \mathrm{~h}$. Cells were then incubated with primary antibodies overnight at $4^{\circ} \mathrm{C}$, washed in PBS, and incubated with Cy3-conjugated mouse IgG antibodies (1:200; GE Healthcare) for $60 \mathrm{~min}$ at room temperature. Slides were prepared using Vectashield with DAPI (Vector Laboratories, Inc) for nuclei counterstaining. Primary antibodies used were: monoclonal anti-mouse stage-specific embryonic antigen-1 (SSEA-1) and -4 (SSEA-4), TRA1-60, TRA-1-81 (dilution 1:50; Chemicon), and antimouse OCT-4 (dilution 1:100; Santa Cruz Biotechnology, Inc.) Human foreskin fibroblasts (HS27 cell line, ATCC) were used as negative controls.

\section{In Vitro Differentiation}

For embryoid body (EBs) formation, cell aggregates were grown in suspension in nonadherent plates as described by Itskovitz-Eldor et al. (16). The differentiation medium consisted of 80\% DMEM, 20\% FBS (Hyclone), $1 \%$ Glutamax (Invitrogen), and 1\% penicillin-streptomicin (Invitrogen). After 1 week, EBs were collected and transferred to $0.1 \%$ gelatin-coated dishes for one more 
week, and then fixed in 4\% PFA and subjected to immunocytochemistry assay as described above. The primary antibodies used were: endoderm: anti-goat SOX-17 and anti-goat HNF-3 $\beta$ (Santa Cruz Biotechnology, Inc.); mesoderm: $\alpha$-actinin (Sigma), and mouse anti-MYOD (BD Pharmingen); ectoderm: MAP2 (Sigma) and NF200 (Sigma). For secondary antibodies anti-goat IgG-FITC (Santa Cruz Biotechnology, Inc.) or anti-mouse IgGCy3 (GE Healthcare) were used.

\section{Teratoma Assays}

Cells from passage 12 were cultured both on Matrigel and on feeder cells. Undifferentiated colonies were dissected mechanically, and approximately 100 cell aggregates (approximately $1 \times 10^{5}$ cells) were injected subcutaneously in C57/B16 nude mice. Teratoma formation was followed for 10-12 weeks after injection. Tumors were dissected, fixed in 4\% PFA, embedded in paraffin, and submitted to histological analysis as described (35).

\section{Karyotype and Microarray Comparative Genomic Hybridization (CGH) Analysis}

Standard G-banding karyotype analysis was performed in BR-1 cells from passage 6 and passage 29 as described elsewhere (13). At least 20 metaphases were analyzed in each group. CGH-array was performed using an array containing 44,000 oligonucleotides (Human Genome Microarray CGH 44A, Agilent Technologies), as described elsewhere (20). Briefly, genomic DNAs from passages 4 and 29 of BR-1, and a normal female were labeled by random priming with $\mathrm{Cy} 3$ - and $\mathrm{Cy} 5$ dCTPs, respectively. Purification, hybridization, and washing were carried out as recommended by the manufacturer. Scanned images of the arrays were processed with Agilent Feature Extraction v9.5.1 and analyzed us- ing CGH Analytics software 3.4.40 (both from Agilent Technologies) with the statistical algorithm ADM-2, and sensitivity threshold 6.0. At least three consecutive oligonucleotides had to have aberrant $\log _{2}$ ratios to be called by the software. The average resolution was approximately $70 \mathrm{~kb}$.

\section{HLA Typing and Analysis of Genomic Ancestry}

Genomic DNA from BR-1 was used for HLA-typing of loci $\mathrm{A}, \mathrm{B}, \mathrm{Cw}, \mathrm{DRB} 1$, and DQB1 at medium resolution, and was performed by the Laboratório de Histocompatibilidade (UNIFESP, Brazil) using the LABType ${ }^{\circledR}$ SSO typing system according to the manufacturer's instructions (OneLambda, Inc). HLA profile of different hES cell lines was obtained from the literature $(17,21)$ or from the International Stem Cell Registry (15) and the European Human Embryonic Stem Cell Registry (10). HLA matching at low resolution for loci A, B, and DRB1 was performed against 1,312,334 individuals from the Brazilian National Registry of Bone Marrow Donors (REDOME) using the Sismatch software (4).

Genomic ancestry was determined by analysis of 40 insertion/deletion (indel) polymorphisms along the autosomes as described by Bastos-Rodrigues et al. (3). These experiments were performed by Laboratório Gene (Belo Horizonte, MG, Brazil).

\section{RESULTS}

Seventy-nine surplus embryos produced for reproductive purposes were thawed and allowed to develop until the blastocyst stage, on day 5. Inner cell masses (ICM) were mechanically isolated from 5 of a total of 45 blastocysts obtained, and the other 40 poor quality blastocysts had only the zona pellucida (ZP) mechanically removed. Both isolated ICMs and whole blasto- day $5(\mathrm{p} 0)$

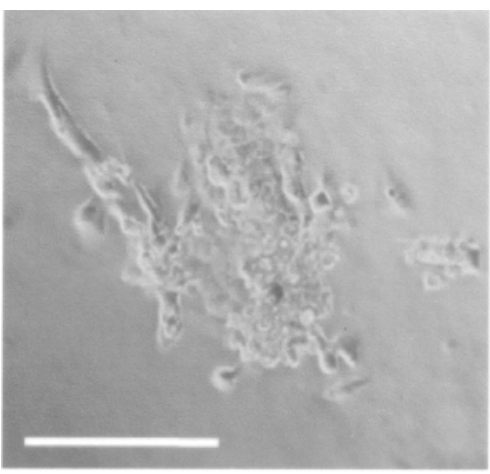

day $12(\mathrm{p} 0)$

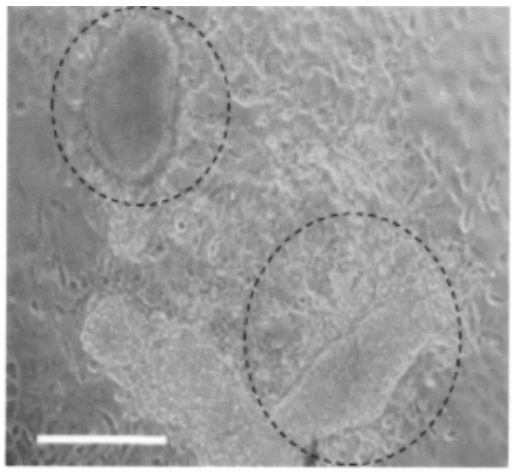

p2

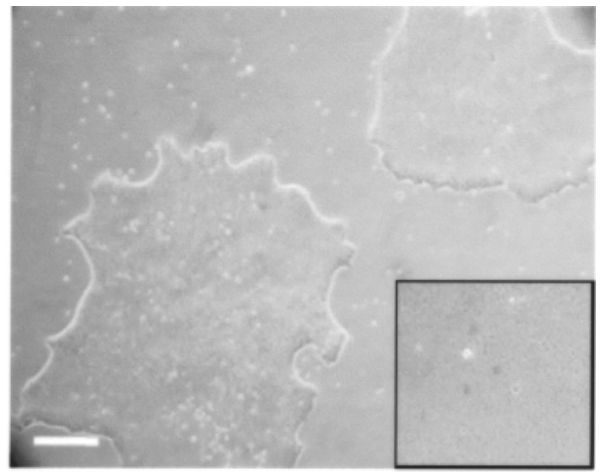

Figure 1. Establishment of a new line of hES cells: light microscopy of cells at different days after plating. Dotted circles indicate cell masses with hES cell-like morphology that were mechanically passaged. Inset shows colony at higher magnification (50 $\times)$, where cells with the characteristic high nucleus to cytoplasm ratio can be observed. Scale bar: $100 \mu \mathrm{m}$. 

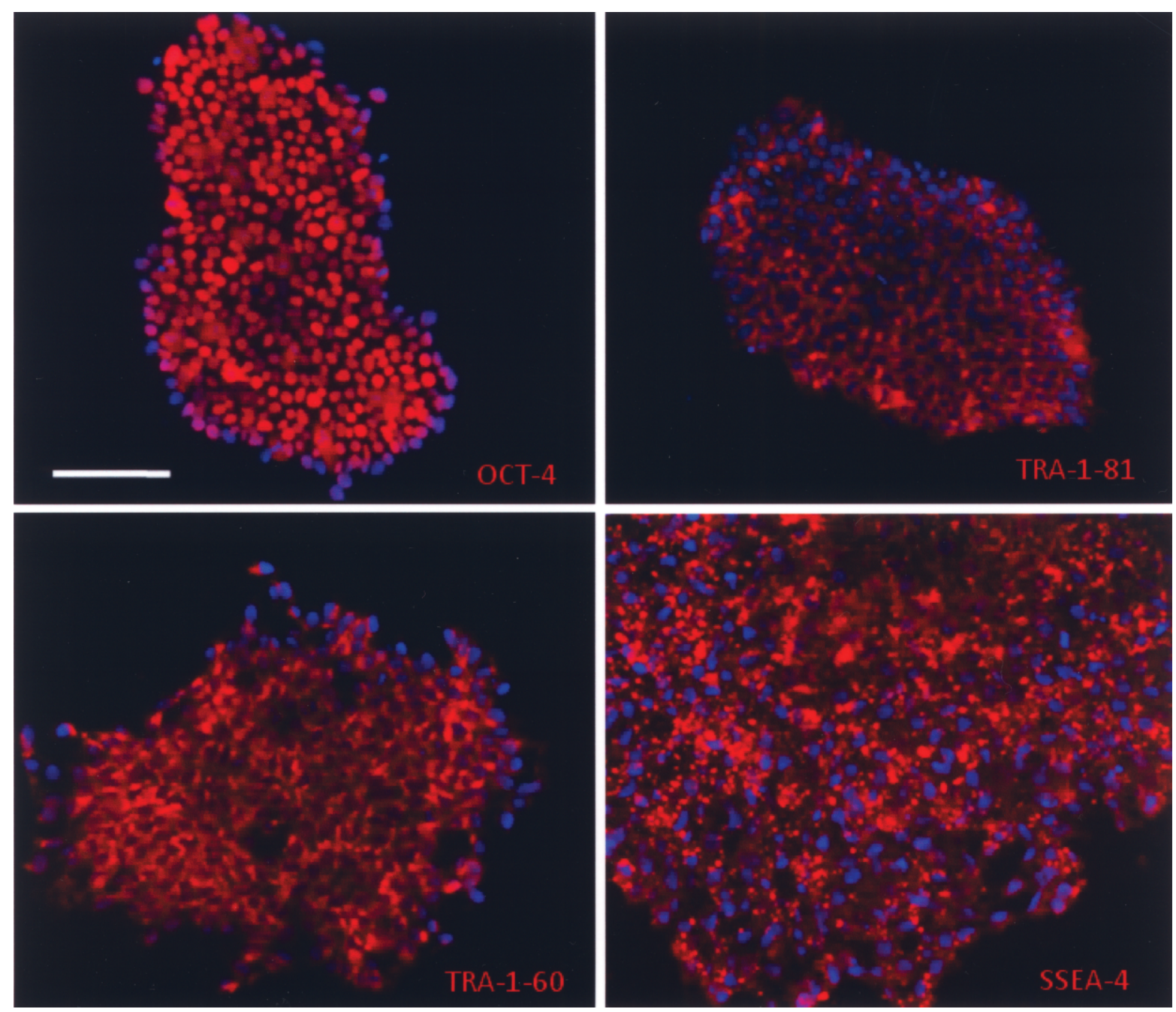

Figure 2. Expression of pluripotency markers. Immunofluorescence of BR-1 cells at passage 6 with antibodies against markers of pluripotency. Cy3-conjugated anti-mouse IgG (red) was used as secondary antibody. Nuclei were stained with DAPI (blue). Scale bar: $100 \mu \mathrm{m}$.

cysts were plated on Matrigel-coated plates and cultured in mTeSR1 medium (StemCell Technologies). From this day on, outgrowths were observed and had half of the medium changed every other day until the first passage (p1), after which complete medium change was performed every day.

Twenty one plated blastocysts ( 3 isolated ICMs and 18 whole blastocysts) attached and grew in culture with mTeSR1 and Matrigel for 7-10 days. We then added mouse irradiated feeder cells (MEFs) to 7 surviving outgrows, and 13 days later, cell clumps from one outgrow (from a whole blastocyst) were mechanically passaged to Matrigel-coated dishes with mTeSR1. Colonies exhibited the characteristic morphology of hES cells, with each cell showing a high nucleus/cytoplasm ratio, form- ing tightly, compact colonies that were mechanically dissociated every 6-8 days and cultured in feeder-free conditions (Fig. 1). This line, named BR-1, was successfully propagated and characterized.

Cells were assayed for antigens correlated with pluripotency by immunofluorescence (Fig. 2). Colonies show a clear nuclear staining pattern for OCT4, and cell surface staining for TRA-1-60, TRA-1-81, and SSEA-4.

We verified the potential of BR-1 cells to differentiate into the three germ lineages in vitro. Cells were cultured in basic medium without FGF in nonadherent culture plates, allowing the formation of embyoid bodies (EBs). After 1 week in suspension, EBs were transferred and cultured 1 more week in gelatin-coated wells. Immunostaining of differentiated cell confirmed differenti- 
ation in endoderm [SOX17 and HNF3 $\beta$ (FOXA)], mesoderm ( $\alpha$-actinin and MYOD), and ectoderm [NF200 (NEFH) and MAP2] (Fig. 3).

Pluripotency of BR-1 cells was also tested by teratoma formation assays. Ten to 12 weeks after subcutaneous injection of undifferentiated cell clumps into nude mice, tumors with both cystic and solid areas were visualized. Histological analysis of the teratomas revealed the presence of tissues derived from mesoderm, endoderm, and ectoderm, demonstrating the pluripotency of BR-1 (Fig. 4).

Chromosomal stability of BR-1 was assayed by both conventional karyotyping and by CGH-array (Fig. 5). Cells at passage 6 and 29 were karyotyped by standard G-banding. At least 20 metaphases were counted, all showing a normal 46,XY chromosome constitution (Fig. $5 \mathrm{~A})$. For analysis at higher resolution, CGH-array was performed, detecting no chromosomal loss or gain at the $70-\mathrm{kb}$ resolution in cells cultured continuously for 6 months, at passage 29 (Fig. 5B). As a positive control, sex chromosome imbalances between BR-1 and the fe- male reference sample were detected. These data indicate that the culture conditions were adequate for derivation and propagation of a karyotypically normal and stable hES cell line. BR-1 has also been successfully propagated on MEFs from passage 2 on, and will be characterized at a later date.

The HLA profile at low resolution of BR-1 and those of 22 other hES cell lines was compared with the Brazilian Bone Marrow Donor Registry (REDOME), consisting of HLA typing of 1,312,334 Brazilians (Table 1). In that subset of the Brazilian population we found no full match for BR-1, nor for cell lines derived in Israel, India, or Spain. In contrast, at least one full match was found to lines established in the US, Singapore, and Sweden. Taken together, the 23 lines analyzed were a match for $0.011 \%(150 / 1,300,000)$ of the Brazilian population represented in REDOME's database.

Genotyping of 40 indel polymorphisms on autosomes (genotypes available upon request, or at www.ib.usp.br/ lance_usp) revealed that the genomic ancestry of BR-1 is $98.4 \%$ European, $0.8 \%$ Amerindian, and $0.8 \%$ African
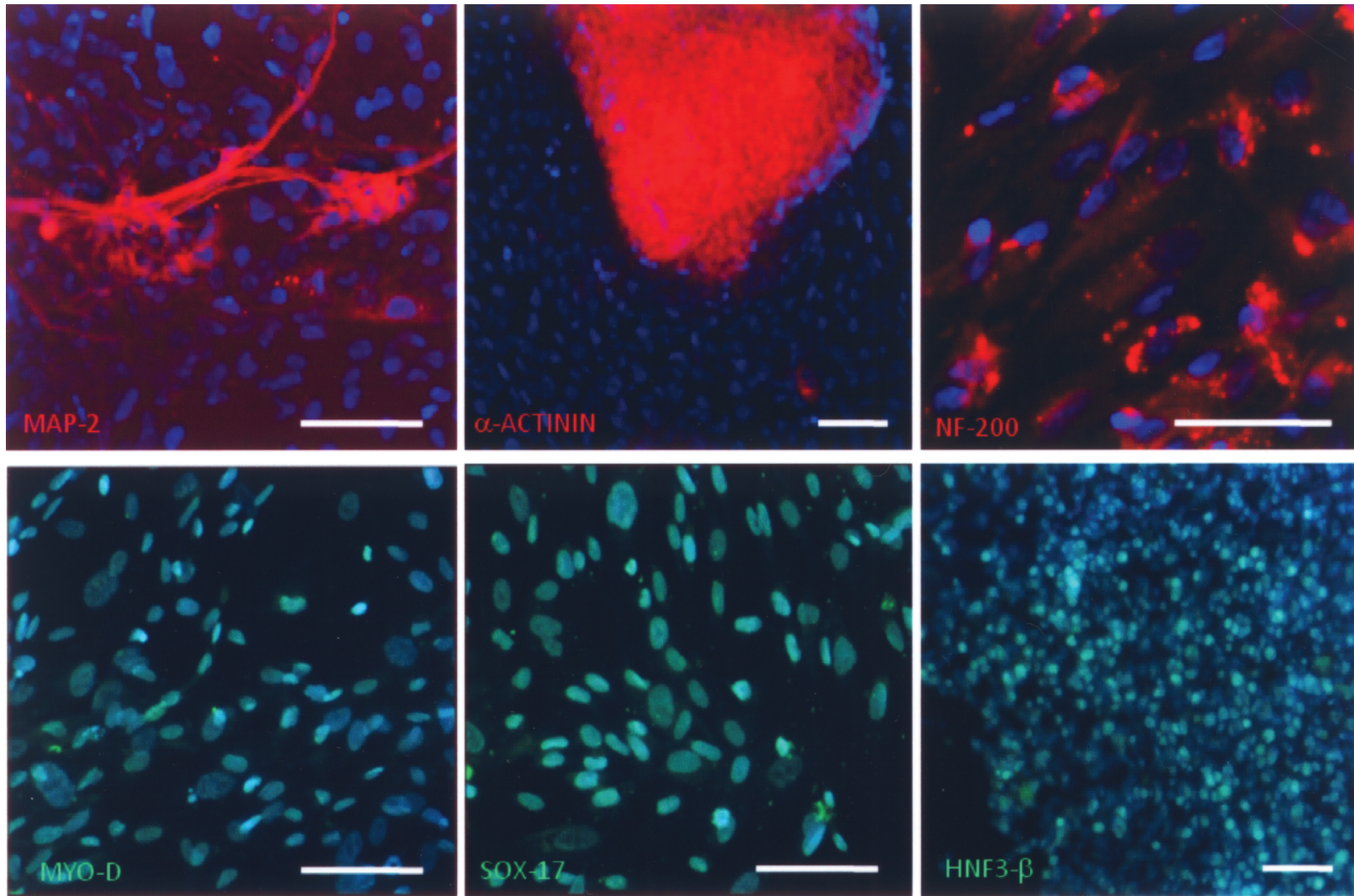

Figure 3. In vitro differentiation of BR-1. Immunofluorescence of in vitro differentiated BR-1 cells, expressing markers of endoderm (SOX-17 and HNF-3 $\beta$ ), mesoderm ( $\alpha$-actinin and MYOD), and ectoderm (MAP2 and NF200). FITC-conjugated anti-goat (green) and Cy3-conjugated anti-mouse (red) were used as secondary antibodies. Nuclei were stained with DAPI (blue). Scale bars: $100 \mu \mathrm{m}$. 

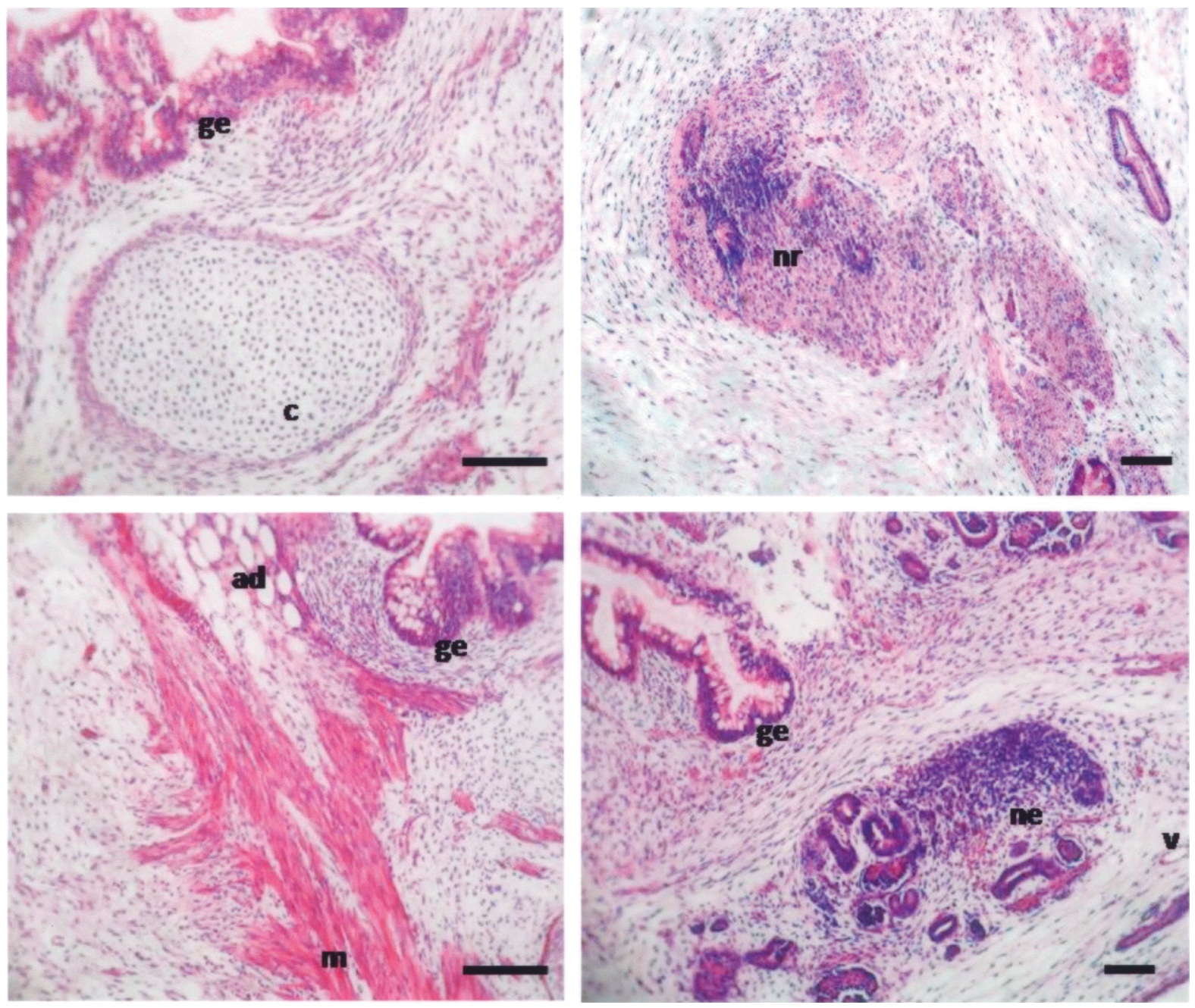

Figure 4. Teratoma formation in nude mice. Histological analysis of hematoxylin-eosin-stained images of sections of teratomas derived from BR-1 hES cell line showing derivatives from the three embryonic germ layers. ad, adipose; c, cartilage; ge, glandular epitethelium; m, muscle tissues; ne, neural epithelium; nr, neural rosettes; v, vessel. Scale bars: $100 \mu \mathrm{m}$.

(Table 2). The same analysis showed that the genomic ancestry of $\mathrm{H} 1$ is also predominantly European $(96.0 \%)$.

\section{DISCUSSION}

As of August 2009 there were more than 300 different lines of hES cells deposited in the International Stem Cell Registry (15). Therefore, what are the motivations to establish new lines? One important reason is the standardization of protocols for derivation and in vitro maintenance of hES cells. In particular, defined conditions for establishing and culturing hES cell should facilitate replication of experiments with those cells in both the basic research and clinical settings. Although defined conditions for culturing hES cells have been described by several groups [reviewed in (37)], to date there is only one report of derivation of hES cell lines in defined medium, TeSR, which differs from mTeSR1 used in this study only by the replacement of bovine by human albu$\min (25,26)$. However, while one cell line was aneuploid in early passages, perhaps due to an alteration already present in the original embryo, the second line became trisomic for chromosome 12 after 7 months in culture. In contrast, BR-1 remained karyotypically stable at passage 29 even at the $70-\mathrm{kb}$ resolution. Therefore, our results show that a defined medium can support the establishment of a karyotipically normal hES cell line. We are currently working on the establishment of new hES cell lines in defined xeno-free medium, which will further facilitate the clinical use of tissues derived from those cells.

The second issue relates to the need to increase the diversity of HLA types in stem cell banks, which in turn will be important to cater to ethnically heterogeneous 
populations in the clinical setting. HLA genes are among the most polymorphic in the entire genome $(18,34)$. There are hundreds of reported alleles for each locus, and the number is still rising as new ones are described. Currently, there is little information about HLA allele frequencies in admixtured populations (1). In particular, Brazil has a population of approximately 190 million individuals with a uniquely high degree of admixture, having different degrees of African, European, and Amerindian ancestry (30). For Brazilian patients subjected to bone marrow transplants, most nonconsanguineous donors are found within the Brazilian population. Therefore, we hypothesized that BR-1 would be a better match for the Brazilian population than hES cells derived elsewhere. However, BR-1 was a worse match to the Brazilian subpopulation represented by approximately 1.3 million individuals registered at the REDOME than seven lines derived elsewhere (Table 1). Interestingly, the hES cell lines with most matches to individuals in that register were derived in the USA (H1; 51 matches) and Singapore (HES4; 58 matches). Nevertheless, those 23 cell lines were full matches at low resolution to only $0.011 \%$ of the Brazilian population. This is in strong contrast with results obtained by a similar analysis performed in the Chinese population (23), where it was found that a local hES cell bank with 188 lines provides a full match to $24.9 \%$ of that population. It will be important to have a greater number of hES cell lines derived from the Brazilian population in order to evaluate whether international or national hES cell banks may better cater to this population.

Finally, another motivation for the derivation of new hES cell lines is to increase the number of genetically variant cell lines available for research and therapy. Indeed, two recent studies of the genetic background of 86 hES cell lines concluded that, despite being from different geographical areas, they were from very restricted ethnic origins, basically European and Middle Eastern/ East Asian (22,27). Both studies concluded that there is currently a lack of representative lines from populations worldwide, and reinforced the need for derivation of hES cells from underrepresented groups.
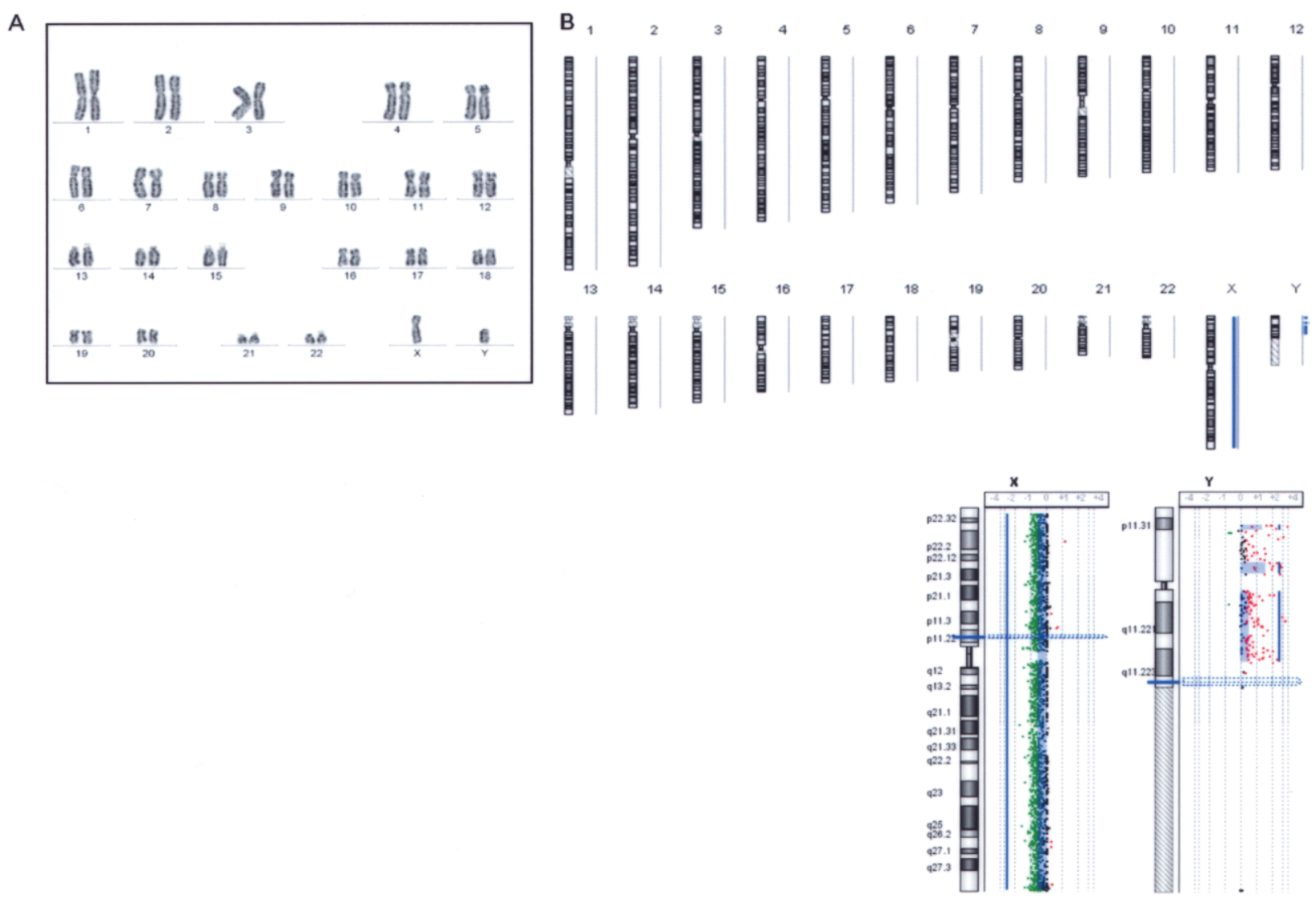

Figure 5. Genomic stability of BR-1 cells. (A) Karyotype with G-banding and (B) CGH-array of cells at passage 29. DNA from a normal female $(46, \mathrm{XX})$ was used as reference. Blue lines indicate differences between BR-1 and the reference DNA. The detailed view of chromosomes $\mathrm{X}$ and $\mathrm{Y}$ shows lower (green dots) and higher (red dots) content of $\mathrm{X}$ and $\mathrm{Y}$ sequences, respectively, in BR1 when compared to the reference DNA. 
Table 1. HLA Matching of Different hES Cell Lines to the Brazilian Population

\begin{tabular}{|c|c|c|c|c|c|c|c|}
\hline hES Cell Line & $\begin{array}{c}\text { Origin } \\
\text { (Country) }\end{array}$ & HLA-A & HLA-B & HLA-C(w) & HLA-DRB1 & HLA-DQB1 & $\begin{array}{c}\text { REDOME } \\
\text { Match* }\end{array}$ \\
\hline $\mathrm{BG} 01 \dagger$ & USA & 0203 & 3549 & 0407 & 0304 & 0203 & 6 \\
\hline $\mathrm{BG} 02 \dagger$ & USA & 2468 & 3535 & 0304 & 1516 & 0306 & 2 \\
\hline $\mathrm{BG} 03 \dagger$ & USA & 0232 & $44-$ & $05-$ & $04-$ & 0303 & - \\
\hline ES-4‡ & Spain & 0232 & 1444 & 0508 & 1313 & 0306 & - \\
\hline ES-6 & Spain & 0124 & 1527 & 0203 & 1113 & 0306 & - \\
\hline H1 (WA01) $\dagger$ & USA & 0203 & 0835 & 0407 & 0103 & 0205 & 51 \\
\hline H7 (WA07) $\dagger$ & USA & 0225 & 1835 & 0412 & 0711 & 0203 & 5 \\
\hline H9 (WA09) $\dagger$ & USA & 0203 & 3544 & 0407 & 1516 & 0506 & 3 \\
\hline H13 (WA13) $\dagger$ & USA & 0325 & 0718 & 0712 & 0107 & 0205 & - \\
\hline H14 (WA14) $\dagger$ & USA & 0325 & 0718 & 0712 & 0107 & 0205 & - \\
\hline HES- $1 \dagger$ & Singapore & 1124 & 1535 & 0812 & 1415 & 0506 & - \\
\hline HES- $-\dagger$ & Singapore & 0202 & 4648 & 0108 & 0415 & 0406 & - \\
\hline HES-3† & Singapore & 1133 & 4055 & 0107 & $12-$ & 0306 & - \\
\hline HES-4† & Singapore & 0203 & 1544 & 0316 & 0407 & 0203 & 58 \\
\hline $\mathrm{HSF}-1 \dagger$ & USA & $11-$ & 1551 & 0814 & 1113 & $03-$ & - \\
\hline HUES7† & USA & 0203 & 3551 & 0414 & 0415 & 0306 & 24 \\
\hline $\mathrm{I} 4 \dagger$ & Israel & 0324 & 3538 & 0412 & $13-$ & $06-$ & - \\
\hline $\mathrm{I} 6 \dagger$ & Israel & 0126 & 3844 & 0412 & 0407 & 0203 & - \\
\hline KIND-1§ & India & 1129 & 0735 & 0415 & 1007 & $03-$ & - \\
\hline KIND-2§ & India & 0130 & 3540 & 1512 & 1415 & 0506 & - \\
\hline $\mathrm{SA} 01 \dagger$ & Sweden & 0102 & 0735 & 0407 & 1315 & 0606 & - \\
\hline $\mathrm{SA} 02 \dagger$ & Sweden & 0123 & 0751 & 0715 & $14-$ & $5-$ & - \\
\hline BR-1 & Brazil & 2368 & 0751 & 0714 & 1215 & 0506 & - \\
\hline
\end{tabular}

REDOME: Brazilian National Registry of Bone Marrow Donors.

*Full match at low resolution.

$\dagger$ International Stem Cell Registry (15).

\$European Human Embryonic Stem Cell Registry (10).

$\S$ Kumar et al. (21).

The Brazilian population is one of the most heterogeneous worldwide, a result of its history of colonization and five centuries of interethnic crosses among Europeans (mostly Portuguese), Africans, and Amerindians (29). Therefore, the genomes of most Brazilians are mosaics, having alleles from different phylogeographical origins (29). The high degree of admixture of the Brazilian population can thus be explored for the derivation of $\mathrm{hES}$ cell lines with novel genetic backgrounds. However, the analysis of the genomic ancestry of BR-1 showed that it is mostly of European origin (98.4\%), similar to the H1 line derived in the US, and not representative of the mosaic genome characteristic of the Brazilian population, where the European contribution ranges from $37 \%$ to $82 \%$ (30).

Despite being based on a single cell line, our results highlight a limitation that may exist in the pool embryos available for research in Brazil. Although the legislation approved in 2005 was pivotal in allowing hES cell research in Brazil (36), it permits only the use of embryos produced for reproductive reasons, and that have been frozen for more than three years. However, assisted reproduction offered by the Brazilian public health system in general does not include cryopreservation of surplus embryos, and therefore the only material available for research comes from private clinics. Assuming that only those couples with a monthly income above 10 minimum wages (approximately US\$2,500) are able to afford the high cost of private assisted reproduction, that Brazilian subpopulation would be mostly composed of people self-identified as caucasian $(81 \%$ according to the demographic census of year 2000 from the Brazilian Institute of Geography and Statistics) (6). Despite the limitations of this classification (30), that group is likely not representative of the Brazilian ethnic admixture. Therefore, in order to explore the full genetic diversity

Table 2. Genomic Ancestry of BR-1 and H1

\begin{tabular}{lcc}
\hline & BR-1 & H1 \\
\hline European & $0.984(0.898-1.000)$ & $0.960(0.836-1.000)$ \\
Amerindian & $0.008(0.000-0.042)$ & $0.005(0.000-0.036)$ \\
African & $0.008(0.000-0.053)$ & $0.035(0.000-0.128)$ \\
\hline
\end{tabular}

Values are shown as percentage of each contribution (confidence interval). 
of the Brazilian population for the establishment of ethnically and HLA-diverse hES cells lines, it will be important to have access to embryos from the more mixed population assisted by the Public Health System. These ethnically mixed hES cell lines may be a valuable resource for research and, in the future, for therapy in genetically heterogeneous populations.

In summary, we have shown that defined medium can support the derivation of a karyotipically stable hES cell line, and we have established the first line from the Brazilian population that adds to the pool of different HLA profiles of pluripotent cells available. Finally, we make an assessment of the compatibility of $23 \mathrm{hES}$ cell lines with the Brazilian population, identifying a large limitation of currently available hES cells to provide compatible tissues for cell therapy in that large population. Recently, a first clinical trial with hES-derived cells was approved by the FDA (2). Although being currently on hold (12), those phase I experiments should provide important data on the real dimension of the issue of immunogeneicity of hES cells in humans. That in turn will enable the scientific community to design more efficient strategies to implement hES cell banking for therapy in different populations.

ACKNOWLEDGMENTS: This work was supported by a grant from Conselho Nacional de Desenvolvimento Científico e Tecnológico/Departamento de Ciência e Tecnologia do Ministério da Saúde (CNPq/MS/DECIT). P.R. received a fellowship from Instituto Mara Gabrilli (img.org.br), and CordVida (www.cord vida.com.br). A.M.F. has a Ph.D. fellowship from Fundação de Amparo à Pesquisa do Estado de São Paulo (FAPESP). We are grateful to Dr. Jeanne Loring and the Center for Regenerative Medicine at The Scripps Research Institute for scientific and technical support, to Dr. Ric Ross for assistance with embryos manipulation, to Maria $R$. Pinheiro and Dr. Carla Rosenberg for genomic stability analysis, and to the Instituto Nacional do Cancer (INCA) and the REDOME for the HLA matching analysis.

\section{REFERENCES}

1. Abdeen, H.; McErlean, C.; Moraes, M. E.; Torres, M.; Campiotto, S.; Galvão, S.; Gouvea, C.; Middleton, D. Identification of three novel alleles of HLA-DRB1 and HLA-A in the Brazilian population. Tissue Antigens 69(6):607-610; 2007.

2. Alper, J. Geron gets green light for human trial of ES cellderived product. Nat. Biotechnol. 27(3):213-214; 2009.

3. Bastos-Rodrigues, L.; Pimenta, J. R.; Pena, S. D. J. The genetic structure of human populations studied through short insertion-deletion polymorphisms. Ann. Hum. Genet. 70:658-665; 2006.

4. Bouzas, L. F.; Salatiel, I.; Salomao, I.; Oliveira, D.; Paraguassú-Braga, F. H.; Abdelhay, E. Análise preliminar das freqüências de alelos de HLA nas unidades armazenadas no Brasilcord, dos doadores do Redome e dos pacientes inscritos no Rereme como amostra da população brasileira. Rev. Bras. Hematol. Hemoter. 30:34-35; 2008.

5. Bradley, J. A.; Bolton, E. M.; Pedersen, R. A. Stem cell medicine encounters the immune system. Nat. Rev. Immunol. 2:859-871; 2002.
6. Brazilian Institute of Geography and Statistics. www.ibge. gov.br

7. Condic, M. L.; Rao, M. Regulatory issues for personalized pluripotent cells. Stem Cells 26:2753-2758; 2008.

8. Drukker, M.; Benvenisty, N. The immunogenicity of human embryonic stem-derived cells. Trends Biotechnol. 22: 136-141; 2004.

9. Drukker, M.; Katchman, H.; Katz, G.; Even-Tov Friedman, S.; Shezen, E.; Hornstein, E.; Mandelboim, O.; Reisner, Y.; Benvenisty, N. Human embryonic stem cells and their differentiated derivatives are less susceptible to immune rejection than adult cells. Stem Cells 24:221229; 2006.

10. European Human Embryonic Stem Cell Registry. www. hescreg.eu

11. Fernandes, A. M.; Meletti, T.; Guimarães, R.; Stelling, M. P.; Marinho, P. A. N.; Valladão, A. S.; Rehen, S. K. Worldwide survey of published procedures to culture human embryonic stem cells. Cell Transplant. 19(5):509$523 ; 2010$.

12. Geron. www.geron.com

13. Gosden, C.; Davdson, C.; Robertson, M. Lymphocyte culture. In: Rooney, D. E.; Czepulkowsky, B. H., eds. Human cytogenetics. Oxford, UK: Oxford University Press; 1992: 37-47.

14. Guasch, G.; Fuchs, E. Mice in the world of stem cell biology. Nat. Genet. 37(11):1201-1206; 2005.

15. International Stem Cell Registry. University of Massachusetts Medical School. www.umassmed.edu/Content.aspx? id $=47856$

16. Itskovitz-Eldor, J.; Schuldiner, M.; Karsenti, D.; Eden, A.; Yanuka, O.; Amit, M.; Soreq, H.; Benvenisty, N. Differentiation of human embryonic stem cells into embryoid bodies compromising the three embryonic germ layers. Mol. Med. 6:88-95; 2000.

17. Josephson, R.; Sykes, G.; Liu, Y.; Ording, C.; Xu, W.; Zeng, X.; Shin, S.; Loring, J.; Maitra, A.; Rao, M. S.; Auerbach, J. M. A molecular scheme for improved characterization of human embryonic stem cell lines. BMC Biol. 4:28; 2006.

18. Kelley, J.; Walter, L.; Trowsdale, J. Comparative genomics of major histocompatibility complexes. Immunogenetics 56(10):683-695; 2005.

19. Kobayashi, N.; Yuasa, T.; Okitsu, T. Regenerative medicine for diabetes mellitus. Cell Transplant. 18(5):491496; 2009.

20. Krepischi-Santos, A. C.; Rajan, D.; Temple, I. K.; Shrubb, V.; Crolla, J. A.; Huang, S.; Beal, S.; Otto, P. A.; Carter, N. P.; Vianna-Morgante, A. M.; Rosenberg, C. Constitutional haploinsufficiency of tumor suppressor genes in mentally retarded patients with microdeletions in $17 \mathrm{p} 13.1$. Cytogenet. Genome Res. 125:1-7; 2009.

21. Kumar, N.; Hinduja, I.; Nagvenkar, P.; Pillai, L.; Zaveri, K.; Mukadam, L.; Telang, J.; Desai, S.; Mangoli, V.; Mangoli, R.; Padgaonkar, S.; Kaur, G.; Puri, C.; Bhartiya, D. Derivation and characterization of two genetically unique human embryonic stem cell lines on in-housederived human feeders. Stem Cells Dev. 18(3):435-445; 2009.

22. Laurent, L. C.; Nievergelt, C. M.; Lynch, C.; Fakunle, E.; Harness, J. V.; Schmidt, U.; Galat, V.; Laslett, A. L.; Otonkoski, T.; Keirstead, H. S.; Schork, A.; Park, H. S.; Loring, J. F. Restricted ethnic diversity in human embryonic stem cell lines. Nat. Methods 7(1):6-7; 2010.

23. Lin, G.; Xie, Y.; Ouyang, Q.; Qian, X.; Xie, P.; Zhou, X.; Xiong, B.; Tan, Y.; Li, W.; Deng, L.; Zhou, J.; Zhou, D.; 
Du, L.; Cheng, D.; Liao, Y.; Gu, Y.; Zhang, S.; Liu, T.; Sun, Y.; Lu, G. HLA-matching potential of an established human embryonic stem cell bank in China. Cell Stem Cell 5(5):461-465; 2009.

24. Lu, J.; Hou, R.; Booth, C. J.; Yang, S. H.; Snyder, M. Defined culture conditions of human embryonic stem cells. Proc. Natl. Acad. Sci. USA 103(15):5688-5693; 2006.

25. Ludwig, T. E.; Bergendahl, V.; Levenstein, M. E.; Yu, J.; Probasco, M. D.; Thomson, J. A. Feeder-independent culture of human embryonic stem cells. Nat. Methods 3: 637-646; 2006.

26. Ludwig, T. E.; Levenstein, M. E.; Jones, J. M.; Berggren, W. T.; Mitchen, E. R.; Frane, J. L.; Crandall, L. J.; Daigh, C. A.; Conard, K. R.; Piekarczyk, M. S.; Llanas, R. A.; Thomson, J. A. Derivation of human embryonic stem cells in defined conditions. Nat. Biotechnol. 24(2):185-187; 2006.

27. Mosher, J. T.; Pemberton, T. J.; Harter, K.; Wang, C.; Buzbas, E. O.; Dvorak, P.; Simón, C.; Morrison, S. J.; Rosenberg, N. A. Lack of population diversity in commonly used human embryonic stem-cell lines. N. Engl. J. Med. 362(2):183-185; 2010.

28. Nakajima, F.; Tokunaga, K.; Nakatsuji, N. Human leukocyte antigen matching estimations in a hypothetical bank of human embryonic stem cell lines in the Japanese population for use in cell transplantation therapy. Stem Cells 25:983-985; 2007.

29. Pena, S. D. J. Brazilians and the variable mosaic genome paradigm. In: Mayo, O.; Leach, C., eds. Fifty years of human genetics: A festschrift and liber amicorum to celebrate the life and work of George Robert Fraser. Kent Town, SA, Australia: Wakefield Press Pty, Limited; 2007: 98-104.

30. Pena, S. D. J.; Bastos-Rodrigues, L.; Pimenta, J. R.; Bydlowski, S. P. DNA tests probe the genomic ancestry of Brazilians. Braz. J. Med. Biol. Res. 42:870-876; 2009.

31. Revazonva, E. S.; Turovets, N. A.; Kochetkova, O. D.; Agapova, L. S.; Sebastian, J. L.; Pryzhkova, M. V.; Smol- nikova, V. I. U.; Kuzmichev, L. N.; Janus, J. D. HLA homozygous stem cell lines derived from human parthenogenetic blastocysts. Cloning Stem Cells 10:11-24; 2008.

32. Swijnenburg, R. J.; Schrepfer, S.; Govaert, J. A.; Cao, F.; Ransohoff, K.; Sheikh, A. Y.; Haddad, M.; Connolly, A. J.; Davis, M. M.; Robbins, R. C.; Wu, J. C. Immunosuppressive therapy mitigates immunological rejection of human embryonic stem cell xenografts. Proc. Natl. Acad. Sci. USA 105(35):12991-12996; 2008.

33. Taylor, C.; Bolton, E. M.; Pocock, S.; Sharples, L. D.; Pedersen, R. A.; Bradley, J. A. Banking on human embryonic stem cells: Estimating the number of donor cell lines needed for HLA matching. Lancet 366:2019-2025; 2005.

34. The MHC Sequencing Consortium. Complete sequence and genemap of a human major histocompatibility complex. Nature 401(6756):870-871; 1999.

35. Thomson, J. A.; Itskovitz-Eldor, J.; Shapiro, S. S.; Waknitz, M. A.; Swiergiel, J.; Marshall, V. S.; Jones, J. M. Embryonic stem cell lines derived from human blastocysts. Science 282:1145-1147; 1998.

36. Triunfol, M. Human embryonic stem-cell research reapproved in Brazil. Lancet Oncol. 9(7):616; 2008.

37. Unger, C.; Skottman, H.; Blomberg, P.; Dilber, M. S.; Hovatta, O. Good manufacturing practice and clinicalgrade human embryonic stem cell lines. Hum. Mol. Genet. 17(R1):48-53; 2008.

38. Yamanaka, S. Strategies and new developments in the generation of patient-specific pluripotent stem cells. Cell Stem Cell 1(1):39-49; 2007.

39. Yang, X.; Smith, S. L.; Tian, X. C.; Lewin, H. A.; Renard, J. P.; Wakayama, T. Nuclear reprogramming of cloned embryos and its implications for therapeutic cloning. Nat. Genet. 39(3):295-302; 2007.

40. Yao, S.; Chen, S.; Clark, J.; Hao, E.; Beattie, G. M.; Hayek, A.; Ding, S. Long-term self-renewal and directed differentiation of human embryonic stem cells in chemically defined conditions. Proc. Natl. Acad. Sci. USA 103: 6907-6912; 2006. 
Anexo 4: Artigo publicado na revista Nature Biotechnology em novembro de 2011. 


\title{
Screening ethnically diverse human embryonic stem cells identifies a chromosome 20 minimal amplicon conferring growth advantage
}

\author{
The International Stem Cell Initiative ${ }^{1}$
}

\begin{abstract}
The International Stem Cell Initiative analyzed 125 human embryonic stem (ES) cell lines and 11 induced pluripotent stem (iPS) cell lines, from 38 laboratories worldwide, for genetic changes occurring during culture. Most lines were analyzed at an early and late passage. Single-nucleotide polymorphism (SNP) analysis revealed that they included representatives of most major ethnic groups. Most lines remained karyotypically normal, but there was a progressive tendency to acquire changes on prolonged culture, commonly affecting chromosomes 1, 12, 17 and 20. DNA methylation patterns changed haphazardly with no link to time in culture. Structural variants, determined from the SNP arrays, also appeared sporadically. No common variants related to culture were observed on chromosomes 1,12 and 17 , but a minimal amplicon in chromosome 20q11.21, including three genes expressed in human ES cells, ID1, BCL2L1 and HM13, occurred in $>20 \%$ of the lines. Of these genes, $B C L 2 L 1$ is a strong candidate for driving culture adaptation of ES cells.
\end{abstract}

In human ES cell cultures, somatic mutations that generate a selective advantage, such as a greater propensity for self-renewal, can become fixed over time ${ }^{1}$. This selection may be the reason for the nonrandom genetic changes found in human ES cells maintained for long periods in culture. These changes, mostly detected by karyotypic analyses, commonly involve nonrandom gains of chromosomes 12, 17, 20 and $\mathrm{X}$, or fragments of these chromosomes ${ }^{2-12}$. The embryonal carcinoma (EC) stem cells of human teratocarcinomas, the malignant counterparts of ES cells, though typically highly aneuploid, always contain amplified regions of the short arm of chromosome 12 and, commonly, gains of chromosomes 1,17 and $\mathrm{X}^{13-16}$. Gain of chromosome $20 \mathrm{q}$ has also been noted in yolk sac carcinoma and nonseminomatous germ cell tumors, which contain EC cells ${ }^{17-19}$. Such observations suggest that these specific genetic changes in ES cells may be related to the nature of pluripotent stem cells themselves rather than the culture conditions. Mouse ES cells also undergo karyotypic changes upon prolonged passage $\mathrm{e}^{20}$, often with gain of mouse chromosomes 8 and 11 (ref. 21); mouse chromosome 11 is highly syntenic with human chromosome 17 (ref. 22).

Structural variants in otherwise karyotypically normal human ES cells have also been described ${ }^{10,11,23,24}$. These structural variants include gains on chromosome 4, 5, 15, 18 and 20 and losses on chromosome 10 , although only gains on chromosome 20 were commonly observed in multiple cell lines.

Marked epigenetic changes have also been noted on prolonged passage; studies of global DNA methylation in human ES cells found considerable instability with time in culture ${ }^{25,26}$. Functional gain of the $\mathrm{X}$ chromosome, resulting from loss of $\mathrm{X}$-chromosome inactivation in culture-adapted ES cells with two karyotypically normal X chromosomes has been reported ${ }^{27}$. On the other hand, some imprinted genes retain their monoallelic expression over long-term culture of human ES cells, although this stability is not invariant for all loci ${ }^{28-31}$.

Because stem cells can adopt alternative fates (that is, self-renewal, differentiation or death), it might be expected that those maintained in the pluripotent state for many passages would be subject to strong selection favoring variants that enhance the probability of selfrenewal ${ }^{32}$. Viewed in this light, the increased frequency of genetic variants in ES cell cultures over time might be considered inevitable ${ }^{33}$. Indeed, ES cell lines do often show progressive 'adaptation' to culture, with the result that late-passage cells may be maintained more easily, showing enhanced plating efficiencies ${ }^{27}$. Similarly, some mouse and human EC cell lines derived from germ cell tumors are nullipotent, as if selected for the capacity for self-renewal exclusively ${ }^{34,35}$. Taken together, these observations suggest that acquisition of extra copies of portions of chromosomes 12, 17, 20 and X by human ES and EC cells is driven by increased dosage of a gene or genes that favor selfrenewal, independent of culture conditions.

However, there are also reports of human ES cell lines that have been maintained for many passages in vitro without overt karyotypic changes. It has been argued that some culture techniques, such as manual 'cutting and pasting' of ES cell colonies, favor maintenance of cells with a diploid karyotype ${ }^{3,6}$. As the appearance of a genetic variant in an ES cell culture must involve both mutation and selection, the low population size in cultures maintained by these methods may simply beat the mutation frequency ${ }^{33}$. Nevertheless, culture conditions themselves might influence the mutation rate independently of selection, and a population bottleneck, such as cloning, could allow a viable genetic variant to dominate in the absence of a selective advantage.

${ }^{1} \mathrm{~A}$ full list of authors and affiliations is provided at the end of the paper. 
Candidate genes from the commonly amplified regions can be posited to provide the driving force for selection of variant ES cells, but direct evidence for the involvement of any specific gene is lacking. For example, NANOG, on human chromosome $12 \mathrm{p}$, promotes the selfrenewal of ES cells when overexpressed ${ }^{36-38}$, but one of the two minimal amplicons of chromosome $12 \mathrm{p}$ in EC cells has been reported to exclude the NANOG locus ${ }^{39}$. It is also unclear to what extent changes affecting different loci are selected independently of one another or whether alterations at some loci act synergistically. Further, overexpression of disparate genes affecting a common pathway(s) could lead to an increased proliferative potential. Although the frequent gain of chromosomes 12, 17, 20 and X in both ES and EC cells argues for a selective advantage independent of culture conditions, changes affecting other regions might be more likely to depend upon culture conditions.

To provide better insight into the frequency and types of genetic changes affecting human ES cells on prolonged passage, the International Stem Cell Initiative (ISCI) surveyed by karyology and high-resolution SNP array 125 independent human ES cell lines, provided by 38 laboratories in 19 countries around the world, particularly to identify the common genetic changes that occur during prolonged culture (Supplementary Table 1). An opportunity was also taken to screen the samples against a specialized custom DNA methylation array focused on polycomb-target genes. These likely play a role in controlling ES cell differentiation and could be primary targets for the types of epigenetic change observed in cancer cells ${ }^{40}$. Thus, they may provide a source of selective advantage for variant stem cells. In most cases, each line was analyzed at both an early- and a late-passage level, using all three types of assay. The scale and design of this screen helped ensure that the ES cell lines sampled were representative of the world population. A group of 11 human iPS cell lines from three laboratories was also included to provide a pilot comparison of these pluripotent cells derived by reprogramming. Our results indicate that the common gains of chromosomes 12 and 17 in human ES cells are unlikely to be driven by the gain of single genes, but that the gain of chromosome 20 may be driven by the gain of a single gene, BCL2L1.

\section{RESULTS}

\section{Diversity and population structure of the cell lines surveyed}

To define the range of ethnicity represented by the human ES cell lines included in this study, we first analyzed the SNP calls identified in the SNP array data by referencing them to ethnically defined human genotyping data sets. Of the samples submitted for SNP analysis, three cell lines were included twice, and four pairs of ES cell lines and a set of three lines were identified as having a full sibling relationship (Supplementary Table 1). After accounting for these, 112 genetically unrelated ES cell lines passed SNP quality-control criteria. Subsequent analysis allowed us to determine whether specific structural variants found in particular cell lines are limited to the population from which they were derived or common to all human ES cell lines studied.

For population structure analysis, the international breadth of this study required the use of a diverse set of reference samples to compare to these 112 genetically unrelated cell lines. The reference samples were pooled from the HapMap ${ }^{41}$, the human genome diversity panel (HGDP) ${ }^{42}$ and the Pan-Asian SNP Initiative ${ }^{43}$ to generate an ethnically diverse set of 1,868 reference samples. We performed cluster analysis ${ }^{44}$ of the human ES cell samples against these reference samples, using the CEU (European), Chinese, Japanese and African HapMap populations as references, to arrive at the population structure of the human ES cell lines analyzed (Fig. 1a).
Of the 112 genetically unrelated ES cell lines, 61 (54\%) were of European ancestry (excluding Middle East-East European and Central-South Asia-South European), 31 (28\%) of Asian ancestry, $3(3 \%)$ of African ancestry, 12 (10\%) of Middle East and East European ancestry, and 4 (4\%) of Central-South Asian and South European ancestry (Table 1). The European ES cell lines were further stratified using a recently described comprehensive European reference set ${ }^{45}$ and were found to match subpopulations from many different regions of Europe (Fig. 1b). The cell lines of Asian descent were stratified into those of East Asian origin, including those of Han Chinese, Korean, Japanese and Indian origin, and those of Central or Central-South Asian origin (Fig. 1c,d). Five of the cell lines classified as Middle East and East European clustered with one another but not particularly close to any of the reference samples used in this study, namely clusters belonging to HGDP-Central/South-Asia, HGDP-Middle East and the HGDP-European samples (Fig. 1d). Four of these five lines were derived in Iran, and are most likely of Persian ancestry, a population not represented in the reference samples. It is notable that the nine ES cell lines most commonly cited in the scientific literature are representative of the genetic backgrounds of populations from northern, northwestern and central European, Han Chinese, Indian and Middle Eastern populations (Table 1).

\section{Karyotype analysis}

Stability of the cell lines. Analyses were carried out on all 120 human ES cell lines (including duplicate and sibling cell lines) provided for karyotyping at both early- and late-passage levels ('paired' lines), as well as on five additional lines that were provided only in early passage (Supplementary Table 1). Among this total of 125 lines, 42 (34\%) had abnormal karyotypes (defined as at least two metaphases with identical, abnormal karyotypes of at least 30 metaphases screened) in at least one passage level. The data from this study confirm that human ES cells are commonly diploid soon after derivation, and that many do retain a normal karyotype after many passages (Fig. 2a).

Late-passage cultures of the paired lines were approximately twice as likely to have a chromosome abnormality (39/120, 33\%) as those from the early-passage cultures (17/120, 14\%). Among the five lines submitted only at an early-passage level, one (20\%) had an abnormal karyotype with an extra copy of chromosome 17q. Of the 39 paired lines with abnormal karyotypes at late passage, 24 were normal at the early passage, whereas the remaining 15 also had abnormalities at both passage levels. In this case, the abnormalities seen at the late passage were mostly similar to those seen at the early passage. About half of all the abnormalities involved combinations of chromosomes 1, 12, 17 and 20 (Fig. 2a).

A number of cultures were mosaic with, mostly, two populations of cells, one with a normal karyotype and one with a particular abnormal karyotype; 10 of 24 with abnormalities only at late passage, and 8 out of 15 with abnormalities at both passage levels were mosaic (Supplementary Table 1). Five lines that were mosaic at early passage showed an increase in the abnormal cell population at late passage. In all of these cases, the abnormality involved extra copies of chromosomes 1, 12, 17, 20 or X. One pair showed additional chromosome changes in the late passage and one pair had unrelated abnormal karyotypes at each passage level. Two lines were scored as abnormal in early passage but normal at late passage. However, both were mosaic, with $3 / 30$ metaphases in one case with a translocated chromosome $\mathrm{t}(2: 19)$, and 5/30 metaphases in the other with a duplication on chromosome 13. Both chromosomal rearrangements were unique to these lines and most likely represent random changes that were outcompeted by the normal cells over time. 
a

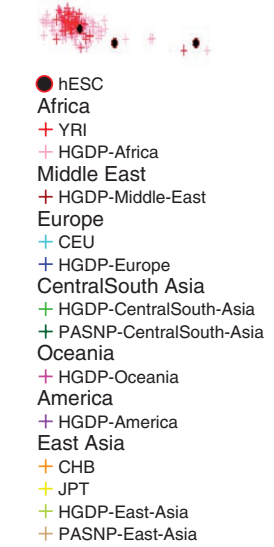

b

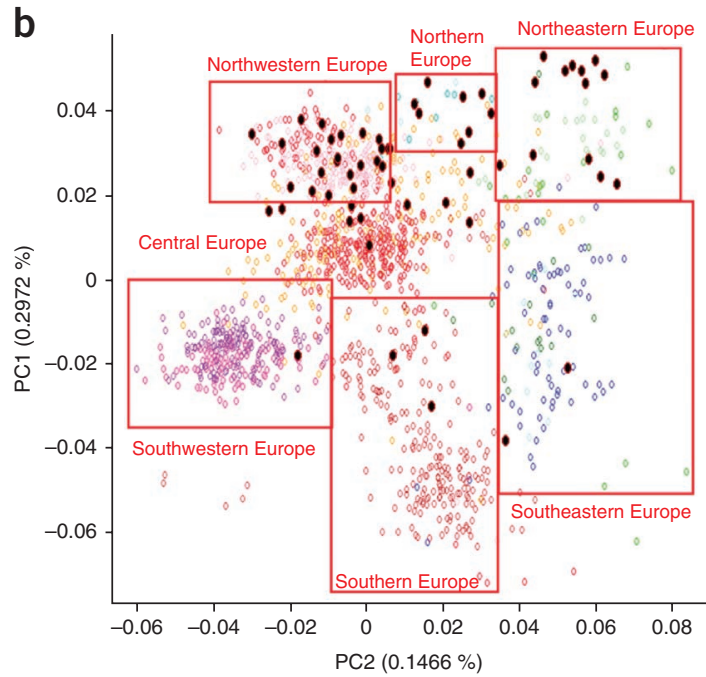

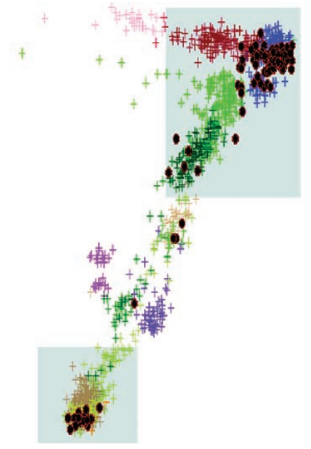

- hESC

Southeastern Europe

Albania

O Bosnia and Herzegovina

O Bulgaria

O Groatia

O Kosovo

Macedonia

Romania
Serbia and Montenegro

O Slovenia

O Slovenia

Southern Europe

O Cyprus

O Cyprus

Southwestern Europe

O Portugal

Northeastern Europe

Czech Republic

O Finland

O Hungary

L Latvia

Russian Federation

Slovakia

Northern Europe

Norway

Denmark

Europe

Northwester

O Ireland

Netherland

Scotland

United Kingdom

Austria

France

Germany
C

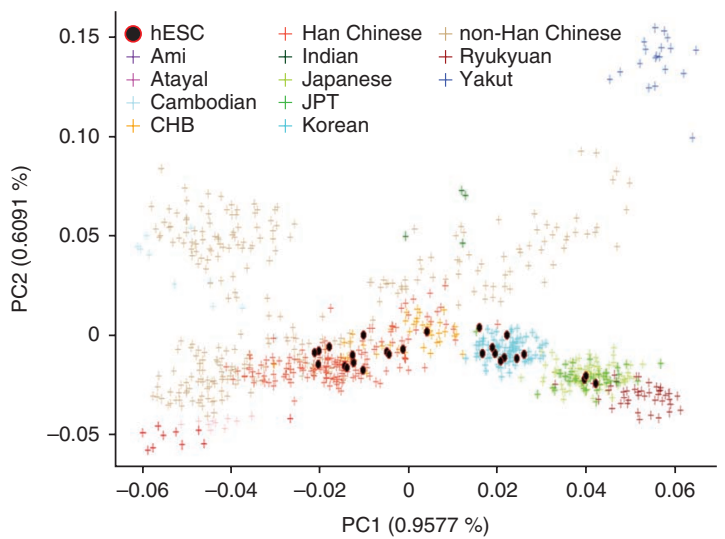

d

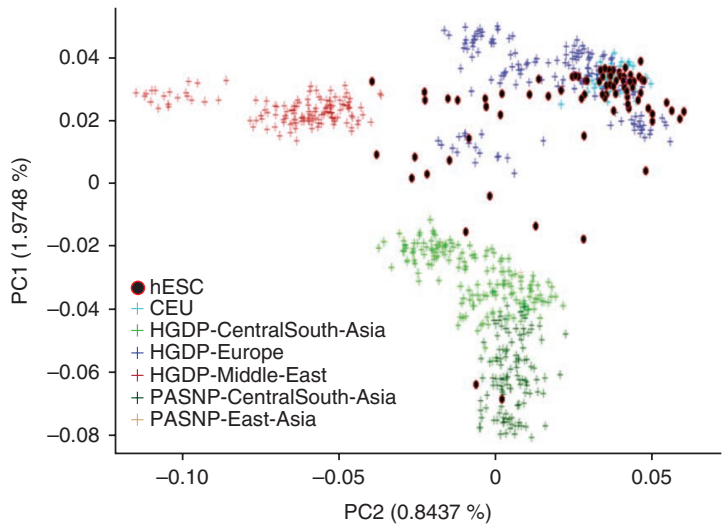

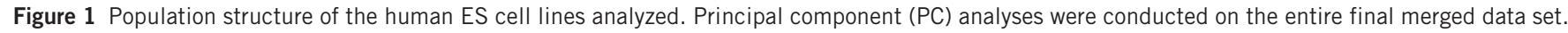
PC1 and PC2 are plotted on the $y$ and $x$ axes, respectively. (a) The overall distribution of the human ES cell lines studied compared to the major ethnic groups identified in the HapMap study ${ }^{41}$, the human genome diversity panel (HGDP) ${ }^{42}$ and the Pan-Asian SNP Initiative ${ }^{43}$. (b-d) The cell lines were further subdivided to show their relationships to European (b), East Asian and Indian (c) and Middle East-European-Central South Asian populations (d).

Among the 11 iPS cell lines examined, three exhibited chromosome abnormalities, a frequency (27\%) comparable to that found in ES cell lines. Of these, one line (RR01) exhibited trisomy 12 at both early and late passage. The other two lines were provided only at one passage level; one had a trisomy 12 (RR05) and one an inversion on chromosome 5 (RR03). None of these abnormalities were present in the somatic cells from which they were derived. These results are consistent with recent analysis of human iPS cell chromosomal instability both in the general frequency of aberrations and over-representation of chromosome 12 alterations ${ }^{12,46}$.

A common source of cells with abnormal karyotypes. The proportion of cell lines with abnormal karyotypes did increase with delta, the difference in estimated number of population doublings $(P=0.048)$ (Fig. 2b). There was also a marked variation in the proportion of abnormal ES cell lines submitted by the different participating laboratories. The 42 abnormal lines were among cell lines submitted by 21 laboratories, whereas no abnormal lines were found among the other 38 lines submitted from the remaining 11 laboratories. This was not directly linked to the delta of the submitted lines and might simply reflect the stochasticity of mutation, or could imply a laboratory effect. The cell lines in each category were from diverse ethnic origins, and were cultured under very similar conditions, although a role for subtle variations in culture technique cannot be excluded. Nevertheless, consistent with suggestions that enzymatic mass-passaging techniques may favor the generation of abnormalities, a twofold higher proportion of the paired lines that had an initially normal karyotype but became abnormal at late passage were passaged by enzymatic methods $(18 / 58,31 \%)$, relative to those passaged by the manual cut-and-paste technique $(6 / 43,14 \%)\left(\chi^{2}, P=0.009\right)$. This effect is significant even after adjusting for delta $(P=0.017)$.

Candidate regions/genes. Aberrations of all chromosomes with the exception of chromosome 4 were observed (Fig. 3). However, most chromosomes were affected in very few instances, and four cell lines with particularly abnormal karyotypes accounted for many of these sporadic changes (Supplementary Table 1). In addition, there were three instances of balanced rearrangements seen as sole aberrations, 
Table 1 Ethnic origin of human ES cell lines analyzed indicating ancestry of those most often cited

\begin{tabular}{|c|c|c|c|}
\hline Ancestry & $\begin{array}{l}\text { Number of } \\
\text { cell lines }^{a}\end{array}$ & $\begin{array}{l}\text { Most commonly } \\
\text { used cell lines }\end{array}$ & $\begin{array}{l}\text { No. citations } \\
(2008 \text { to } 2009)^{\mathrm{b}}\end{array}$ \\
\hline European & $63\left(61^{c}\right)$ & & \\
\hline Italian & 4 & & \\
\hline Southwestern European & 2 & & \\
\hline Southeastern European & 2 & & \\
\hline Northeastern European & $14^{\mathrm{d}}$ & & \\
\hline Northern European & 8 & BG01 & 13 \\
\hline Northwestern European & $24^{d}$ & HUES7 & 18 \\
\hline Central European & 11 & $\mathrm{H} 1$ & 95 \\
\hline Asian & $33\left(32^{c}\right)$ & & \\
\hline Central Asian & 3 & & \\
\hline Central-South Asian & 1 & & \\
\hline \multirow[t]{2}{*}{ Han Chinese } & 14 & HES2 & 16 \\
\hline & & HES3 & 14 \\
\hline Japanese & 3 & & \\
\hline Korean & 9 & & \\
\hline Indian & $3^{d}$ & HES-1 & 6 \\
\hline African & $4\left(3^{c}\right)$ & & \\
\hline East African & 1 & & \\
\hline West African & $3^{d}$ & & \\
\hline \multirow[t]{4}{*}{ Middle East-East European } & $14^{\mathrm{e}}\left(12^{\mathrm{c}}\right)$ & & \\
\hline & & $\mathrm{H} 9$ & 122 \\
\hline & & $\mathrm{H} 7$ & 25 \\
\hline & & HSF-6 & 12 \\
\hline Central-South Asia South & 4 & & \\
\hline
\end{tabular}

\section{European}

Total cell lines

$118\left(112^{c}\right)$

aThe numbers of cell lines shown includes only those that passed quality control for SNP analysis. bUMass Stem Cell Registry (http://www.umassmed.edu/iscr/hESCusage.aspx). ${ }^{c}$ Total number of genetically unrelated cell lines. Includes two cell lines from siblings. Includes three cell lines from siblings.

a translocation between 2 and 19 in an early-passage human ES cell culture, an inversion of 11 in a late-passage culture, for which the early passage was normal, and a Robertsonian translocation between chromosome 21 and 22 in both passages of one line. There were also abnormalities affecting chromosome 7 in seven ES cells, but five came from one laboratory, suggesting an unknown cause particularly associated with that group, perhaps related to their derivation of ES cells from prenatal genetic screening material. By contrast, in most abnormal lines (25/42), the changes involved one or more of chromosomes $1,12,17$ and 20 . Of the 17 lines that were abnormal in early passage, eight had abnormalities involving these chromosomes, whereas, of the 24 lines that acquired abnormalities between early and late passage, 16 lines had changes involving acquisition of one or more of these chromosomes (Fig. 2a). Among the gains, there were minimal amplicons affecting the telomeric region of chromosome 17 (17q25) in two lines, and another affecting 20q11.2 was apparent in another line (Fig. 3). Gains of only the short arm of chromosome 12 were found in three cell lines.

The large differential in frequency between gain and loss of chromosomes is remarkable. In contrast to the $39 \mathrm{ES}$ cell lines that showed gains of chromosomal material in late passage, 20 lines showed losses of chromosomal material. However, only two lines exhibited chromosomal deletions that were not caused by unbalanced translocations (one, UU03, had two unrelated deletions of chromosomes 6 and 18), although even in these there were also unrelated chromosome gains. Excepting the deletions on chromosome 7, which only occurred in the lines from one laboratory, three regions showed recurrent loss, 10p13-pter (five cases), 18q21-qter (five cases) and 22q13-qter (three cases); in several cases these were the sole changes (Fig. 3).

Structural changes determined by molecular karyotyping

Identification of ES cell-associated structural variants. As genomic structural changes do occur below the $\sim 5 \mathrm{MB}$ detectable limit of karyotyping, we used SNP data to identify structural variants and detect structural changes down to a minimum of $1 \mathrm{~kb}$ in length. We identified structural variants for all samples that passed quality control, but restricted our detailed analyses to those cells judged to have a normal karyotype, because of the difficulty of ascribing functional significance to a small structural genomic change in a background of a much larger karyotypic abnormality. Nevertheless, we did examine the breakpoints in six cases of balanced rearrangements (PP-107, NN12, J-02, CC-05, AA-03, RR-03) but found no evidence of structural variants associated with these (Supplementary Table 1). In addition, although loss of heterozygosity can be detected with the SNP platform, we focused our attention primarily on structural variant analysis as this is the more likely structural change to lead to a selective advantage. Nonetheless, we provide a spreadsheet of overlapping loss of heterozygosity across the 225 human ES cell samples and an associated .bed file with all loss-of-heterozygosity calls (Supplementary Data Sets 1 and 2). Structural variants were identified in the 200 DNA samples from karyotypically normal ES cells that passed quality control by comparison with the reference genome (hg18). Further quality controls removed one sample due to an extremely high number of structural variants called and two more for extremely high total length of structural variants (Supplementary Fig. 1). A total of 27,409 deletions with an average size of $40.2 \mathrm{~kb}$, and 7,413 duplications with an average size of $95.4 \mathrm{~kb}$, were detected. The sizes of these structural variants and the total number of differences between deletions and duplications are consistent with previous structural variant studies of human populations ${ }^{47}$. As structural variants are a common feature of variation between individuals, the majority of structural variants detected in the human ES cells most likely represent the condition of the genomes of the respective embryos from which they were derived, and are unrelated to human ES cell culture.

To aid in distinguishing culture-associated structural variants, we compared the human ES cell structural variants to those identified using the same platform to analyze a set of 267 HapMap samples (raw data directly supplied by Illumina). Though relatively restricted in population diversity compared to our human ES cell data set, the HapMap samples provide a set of common reference structural variants. Our subsequent analyses focused only on variant regions enriched in human ES cell lines over the HapMap samples. We identified 504 regions of gain and 860 regions of deletion in the karyotypically normal ES cell lines as 'ES cell associated' (Supplementary Data Set 3 and Supplementary Table 2).

Genome-of-origin variants. The apparent ES cell-associated structural variants most likely include some rare and/or localized variants absent in the HapMap set, yet unrelated to human ES cell culture selection. There are a number of examples in which a particular variant occurs in a single line in both the early and late passage. Although we cannot exclude that such variants arose in culture before the early-passage samples being obtained, it is more likely they represent rare and/or localized variants present in the genomes of the donated embryos. We did see such a case among the iPS cell lines for which we have SNP data from the parental somatic cell line. For instance, in three iPS cell lines derived from the same parental fibroblast, the same rare gain (chr12:106,928,902-107,008,902) was detected in both the early and late passages and the parental line (Supplementary Data Set 3). Also, among the sibling human ES cells lines, we found recurring rare variants specific to each family. For instance, a gain at chr3:45,220,749-45,263,539 was found in the early and late passages of human ES cell lines G02 and G05, although this allele was absent in G04, the third of these sibling lines. At another 
Figure 2 Cytogenetic changes occurring during prolonged passage of human ES cells. (a) Percentage of human ES cell line pairs that exhibited a karyotypic abnormality in either early or late passages, or both. Cell lines were excluded if they were known to be derived from karyotypically abnormal embryos. The ES cell pairs are grouped according to whether the chromosome change was observed at late passage only (normal early, abnormal late), both at early and late passages (abnormal early, abnormal late) or early passage only (abnormal early, normal late) and no chromosomal change (normal early, normal late). The percentage of cell lines that have individual gains of chromosomes $1,12,17$ and 20 , gain of chromosomes 1 and 17, or gain of chromosomes 1, 12, 17 and 20 are highlighted. Chromosome changes not involving 1, 12, 17 and 20 are indicated as 'Other'. The numbers above each bar indicate the total number of lines that fall into the four categories out of the total number of pairs of lines analyzed. Two cell lines (C02 and CC05) in the 'abnormal early, abnormal late' category were known to be derived from karyotypically abnormal embryos (a trisomy 13 and ring chromosome 18 ). One abnormal cell line (AA06) has been excluded from this figure as only one passage was available for analysis. (b) Proportion of pairs of lines that acquired karyotypic abnormalities over different periods in culture. The pairs of lines are grouped according to 'Delta', the difference in estimated population doublings between the early and late passages. Only those lines that had a normal karyotype at the early-passage level were included in the analysis, and of those only 115 pairs could reliably be assigned an estimated population doubling time estimate.

location, chr3:167,536,633-167,837,107, a gain occurs in the early and late passage of all three of these sibling lines. For the purposes of this study, we have assumed that none of these rare variants arose during ES cell culture, and we define them as 'genome-of-origin' variants (Supplementary Table 2).

Dynamically changing variants. Some structural variants that were detected are represented in the HapMap population and change dynamically in ES cell culture, suggesting the labile nature of at least some genomic elements. For example, 18 human ES cell lines had a gain at chr17:75,289,455-75,296,305 (Supplementary Table 2, labile structural variant), but this was also present in four HapMap samples. Among the human ES cell samples, this structural variant was present in the late but not early passage of four lines, but in five other definitive cases it was present in the early but not late passage. Thus, this represents a dynamically changing variant with no evidence for positive selection in human ES cell culture but provides an example of the labile nature of the human genome.

Structural variants enriched in late-passage cultures. In the subset of structural variants enriched in the ES cells, there was no overall trend toward a gain of total structural variant numbers between earlypassage and late-passage samples: that is, there was an increase in the total number in the late passage of some lines, but a decrease in others (Supplementary Table 2). Among the particular structural variants that did show increases in several lines in a late passage, a number encompassed regions known to encode genes that may be relevant to human ES cell behavior, but they were isolated instances. For example, a deletion variant spanning the SOX21 locus, a gene encoding a transcription factor associated with differentiation of human ES cells, was found in one line (UU03-E), and a minimal deleted region at chr4:983425-997875, which spans the promoter and first exon of FGFRL1, was present in the late but not early passage of two lines (L03-1, TT20-1). FGFRL1 is expressed in human ES cells and may act as an inhibitory sink for FGF2, which is important for human ES cell maintenance ${ }^{48}$. Late-passage samples of both the MM01 and TT20 lines share a minimal overlapping deletion variant of $\sim 540 \mathrm{bp}$ at chr3:196,472,618-196,473,157. This spans a highly conserved open reading frame (C3orf21) that is expressed in human ES cells but has no known function ${ }^{48}$.

\section{Structural variants in karyotypically normal ES cells}

We next analyzed structural variants in regions subject to common karyotypic abnormalities. In one region of chromosome 1q, two cell lines (V09 and FF01) in late, but not early, passage, have an overlapping 3.1 MB gain (chr1:199,985,282-203,092,388), which spans $J A R I D 1 B$, a polycomb-related gene encoding a histone $\mathrm{H} 3$ lysine-4demethylase ${ }^{49,50}$. On chromosome 12, two cell lines (B02 and F04) have an overlapping gain of 1.1 MB in chr12:5,592,150-6,749,326 in the late-passage samples. This structural variant is within a minimal amplicon identified by karyology (12p13.31) and includes NANOG, $C D 9$ and GAPDH, all of which are expressed in human ES cells. There was little evidence for repeated occurrence of gains below the resolution of standard banding techniques in regions of chromosome 17 (Supplementary Fig. 2).

In contrast, there was a striking occurrence of a structural variant gain within chromosome 20 in 22 karyotypically normal cell lines. Notably, these gains, many validated by quantitative PCR (Supplementary Fig. 3), are within the minimal amplicon 20q11.2 found by karyology (Fig. 4). Among these 22 cell lines, there were five instances where the gain was detected in both early and late passage but 17 instances where it was detected only in the late passage. There were no instances of this gain in early passage but absence in late passage of the same cell line. This gain was also present in an ES cell line (J01) that had an abnormal karyotype at late passage and in an iPS cell line (RR01) that contained an extra copy of chromosome 12 (Supplementary Table 1). This strongly suggests that once genomic rearrangements occur in this region, they provide a positive selective advantage during subsequent culture. The least difference in passage number between the early and late passage from the same cell line, which had the gain in the late passage alone, was 22 . The apparent strong positive selection for gain of this region suggests that a gene providing a cell-autonomous functional advantage under normal human ES cell culture conditions is encoded within the DNA of the 

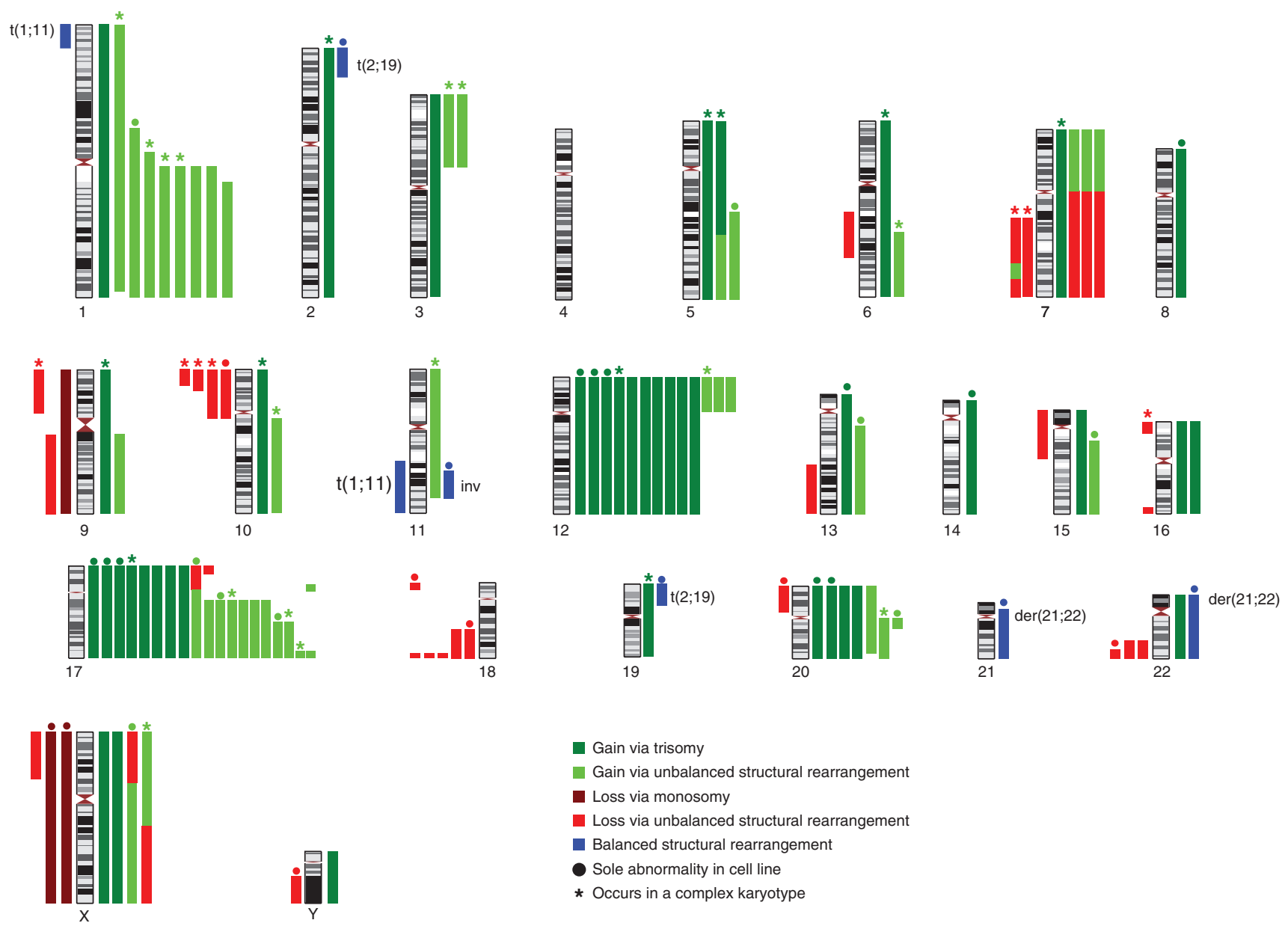

Figure 3 Ideogram demonstrating the chromosome changes found in this study. Each colored bar represents one chromosome change occurrence in one cell line. Chromosome losses and gains are shown to the left and right of the ideogram, respectively, except that those instances where a single chromosome rearrangement results in a gain and a loss the colored bars are shown together for clarity. The cytogenetic changes are color coded: Maroon, loss of a whole chromosome (monopsony); red, loss via a structural chromosome rearrangement (unbalanced translocation or interstitial deletion); dark green, gain of a whole chromosome (trisomy); light green is gain via a structural chromosome rearrangement (unbalanced translocation or interstitial duplication); blue represents the occurrence of an apparently balanced rearrangement the nature of which is labeled. Instances in which a change affected only a single chromosome are denoted by $\bullet$, whereas changes associated with complex karyotypes ( $>5$ unrelated chromosome aberrations) are denoted by $\star$. Two cell lines (CO2 and CC05) were known to be derived from karyotypically abnormal embryos and contain a trisomy 13 and ring chromosome 18 respectively. iPS cell lines are excluded from this figure. Based upon these studies the minimal critical chromosomal regions subject to gain in culture adapted human ES cell lines were 1q21-qter, 12p11-pter, 17q21.3-qter and 20q11.2. The minimal regions subject to loss were 10p13-pter, 18q21-qter and 22q13-qter.

shared overlapping region. Moreover, three cell lines (F-01, Q-02 and K-05) that had a normal karyotype and a 20q11.21 structural variant gain in early passage acquired an abnormal banded karyotype in samples from later passage. The late-passage abnormal karyotypes of F-01, Q-02 and K-05 were 46,XX,der(15)t(15;17)(p11;q21); (47,XX,+der(1) $(\mathrm{t}(1 ; 1)(\mathrm{p} ? 21.2 ; \mathrm{q} 11)$; and 47,XX,t(1;11)(p?36;q13), trp $(17)(\mathrm{p} 11.2),+20$, respectively. This preliminary evidence suggests that early gains in 20q11.21 might promote further subsequent genetic change.

The duplicated regions of chromosome 20 in the various cell lines and the minimal amplicon are diagrammed in Figure $\mathbf{4 b}$. The proximal ends of each of the structural variant gains within chromosome 20 are presumed to lie in a nonbridged sequencing gap sized at $1 \mathrm{MB}$ near the centromeric region of the long arm. The most proximal SNP identified in all these gains is the first occurring after this gap, at position 29,267,954. The distal end of the gain varies across the lines. The longest gain extends to $31,793,485$ with a measured length of 2.5 MB, similar to the shortest karyotypically identified gain in this region, $\operatorname{dup}(20) \mathrm{q} 11.21$ in cell line UU01 (Fig. 3). The shortest gain is $0.55 \mathrm{MB}$ extending to 29,821,940 and contains 13 genes (Fig. 4c). Three of these genes, ID1, BCL2L1 and HM13, are known to be expressed in human ES cells based on mRNA-Seq data (Fig. 4c) and published microarray data ${ }^{27}$. Although a single RefSeq-annotated microRNA lies in this region, there is no evidence for its expression in human ES cells ${ }^{51}$. Further, combined with the mRNA-Seq data, ChIP-Seq data from H1 human ES cells of histone modifications, considered universal predictors of enhancer and promoter activity (H3K4me3, H3K27ac), do not suggest additional functional regions other than those associated with the three RefSeq genes identified as expressed in human ES cells (Fig. 4c).

When four pairs of cell lines with and without the chromosome 20 gain were analyzed, there was no clear correlation between increased expression and the presence of the 20q11.21 gain for these three expressed genes (Fig. 4d). Nevertheless, preliminary results indicated a strong selective advantage in culture for cells with the gain 
a
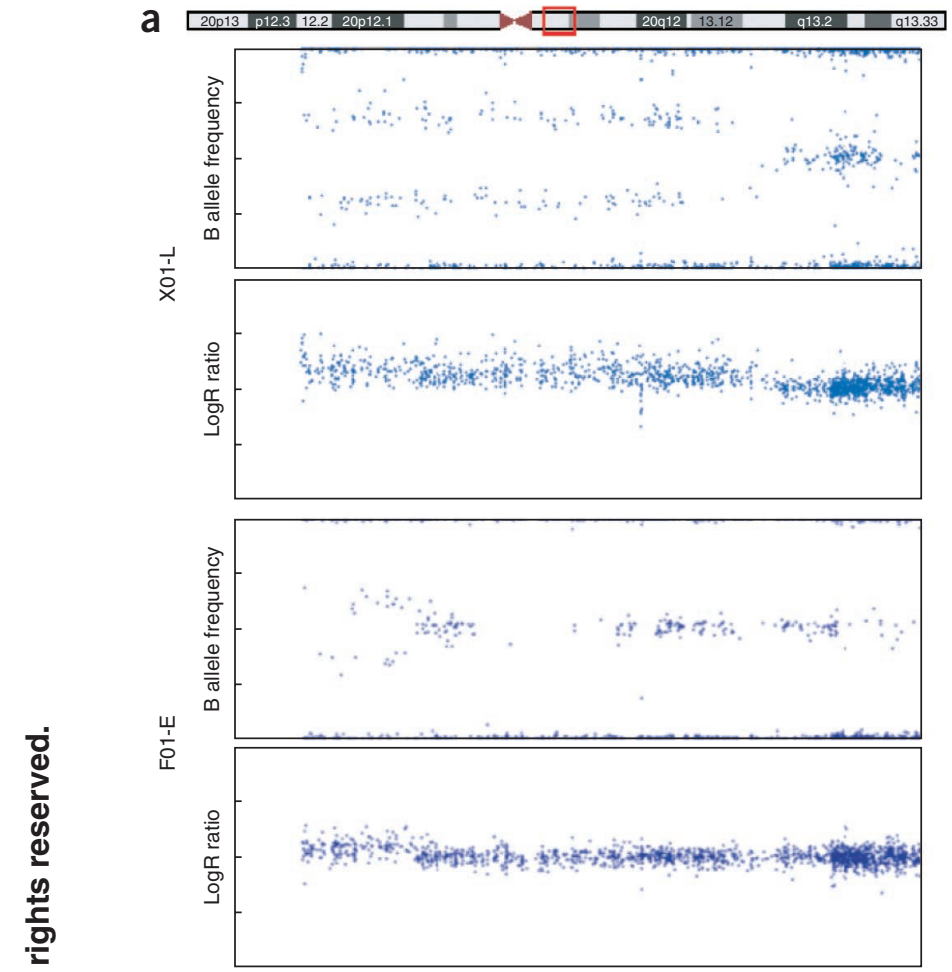

C $1,249-\mathrm{H} 1 \mathrm{hESC}$ mRNA-Seq positive strand read mapping

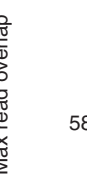

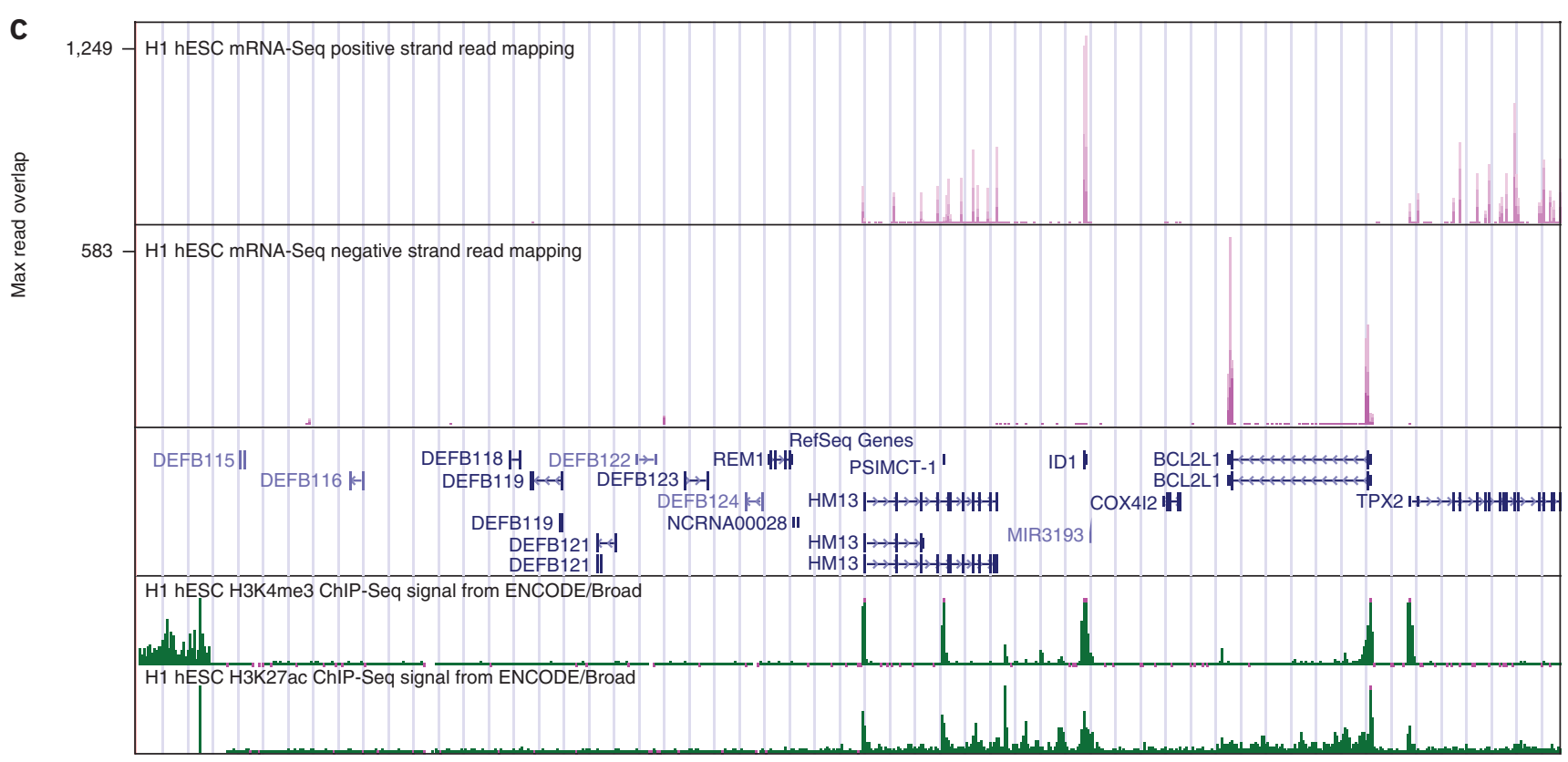

b
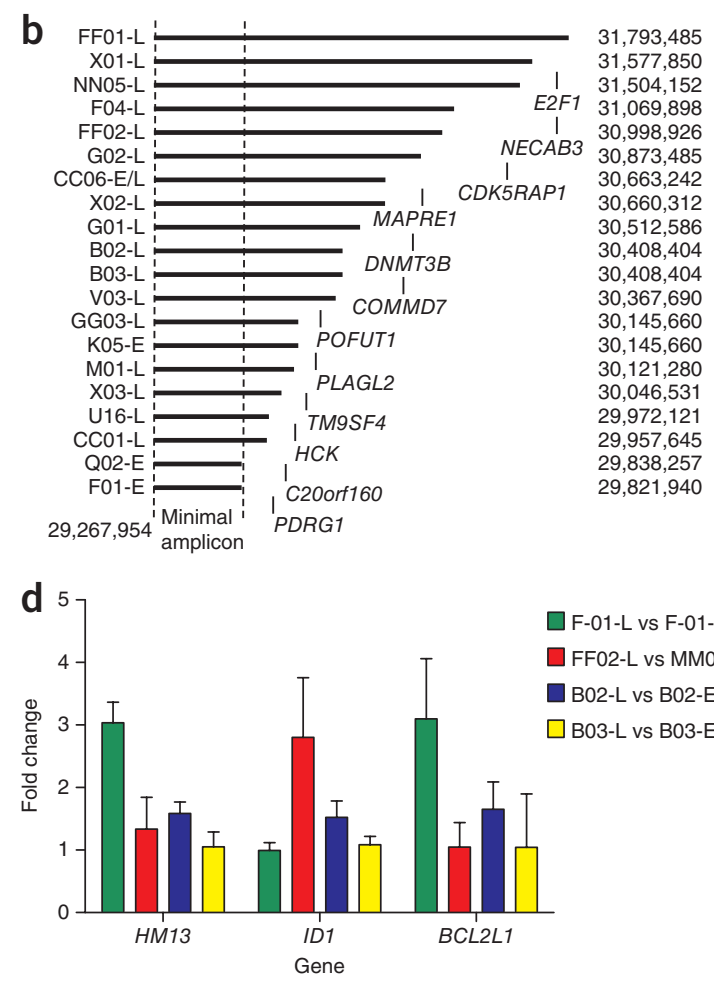

F-01-L vs F-01-E $\square$ FF02-L vs MM01-E $\square$ B02-L vs B02-E $\square$ B03-L vs B03-E

Figure 4 Copy number variation occurrence in human ES cell lines during prolonged passage. (a) $20 q 11.21$ gain. The region on chromosome 20 frequently found to experience gain over extended human ES cell culture is indicated by the red boxed region in the chromosome ideogram. Also shown are the B allele frequency and logR ratio plots representing instances of one of the longest and one of the shortest $20 \mathrm{q} 11.21 \mathrm{structural}$ variants. (b) Length representation of all individual occurrences of gains in the $20 q 11.21$ region. Samples from which the structural variant was derived are indicated on the left-hand column. The invariant $5^{\prime}$ region and the variable $3^{\prime}$ positions are indicated. Position of genes outside of the minimal amplicon that show greater than 20 RPKM level of expression in human ES cells are shown (RPKM = number of reads that map per kilobase of exon model per million mapped reads for each gene). (c) Expression, RefSeq gene, and regulation tracks in the minimal amplicon. Positive and negative strand mRNA-Seq data from $\mathrm{H} 1$ human ES cells indicating polyA RNA transcripts expressed within the minimal amplicon region (chr20:29,267,954-29,853,264) are shown together with H1 human ES cell ChIP-Seq data of histone modifications considered universal predictors of enhancer and promoter activity. (d) Comparison of expression levels of three genes (HM13,IDI, BCL2L1) contained within the identified minimal 20q11.2 amplicon between early- (normal) and late-passage (20q11.2 CNV carrying) samples. MMO1 and FF02 are genetically identical sub-lines from two separate laboratories, MM01 has no amplification at 20q11.2, whereas FF02 possesses a copy number change at $20 \mathrm{q} 11.2$ that includes the identified minimal amplicon (b). 


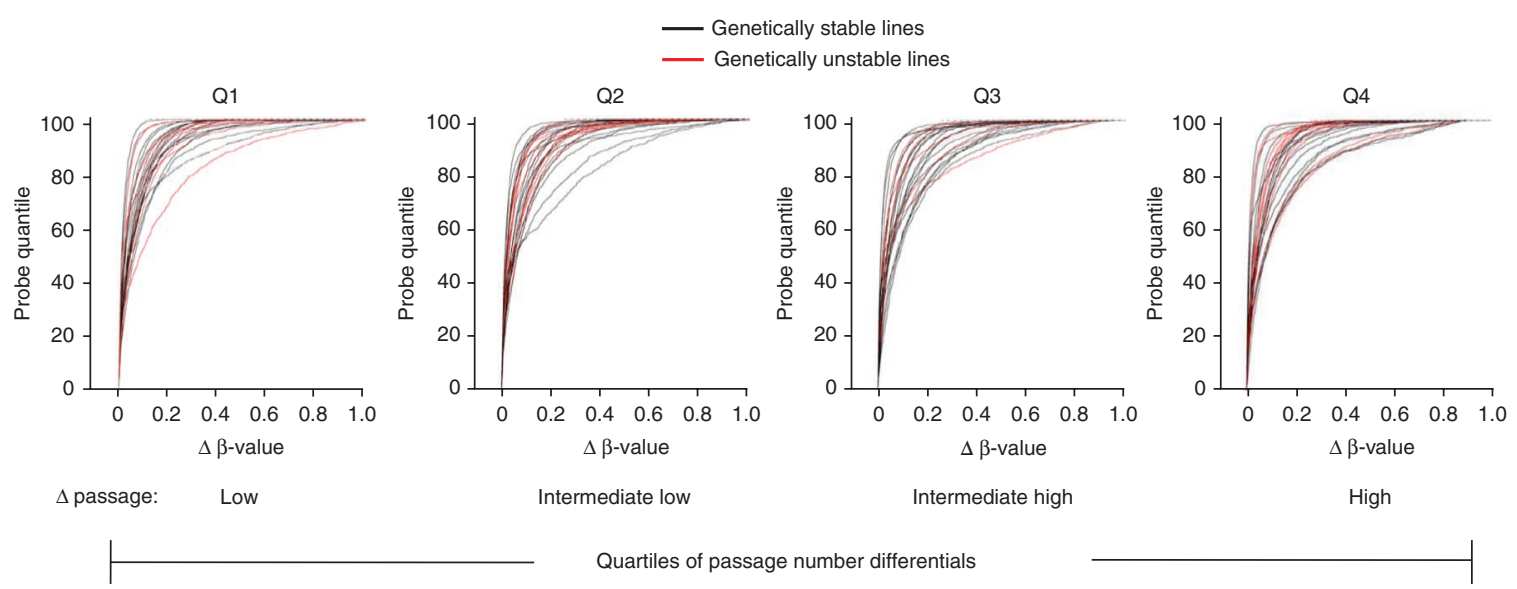

Figure 5 Cumulative distribution function of methylation changes in human ES cells in this study. The change in DNA methylation is represented by empirical CDF curves of the absolute difference in DNA methylation between early-and late-passage cell-line pairs for all 1,536 analyzed probes. The black curves denote genetically stable lines; the red curves denote genetically unstable lines. All analyzed lines were divided into quartiles based on the passage-number difference between the early and late member of each pair. The first quartile contains the lines with the lowest difference in passage number between the early and late sample (range 4 to 47), whereas the fourth quartile contains the lines with the highest difference in estimated population doublings (range 210 to 1,482 ).

over those without (Supplementary Fig. 4). It has also been recently reported that $\mathrm{Bcl}-\mathrm{X}_{\mathrm{L}}$, the long, anti-apoptotic isoform encoded by the BCL2L1 locus, can suppress apoptosis in human ES cells and increase their cloning efficiency ${ }^{52}$. Further, when we transfected MM01 ES cells with a constitutive vector encoding Bcl- $\mathrm{X}_{\mathrm{L}}$, the predominant isoform expressed in human ES cells, these cells showed a distinct growth advantage with respect to the parental cells (Supplementary Fig. 4).

\section{DNA methylation analysis}

To examine whether cell lines that are genetically unstable at the karyotype level tend to show higher levels of epigenetic instability, we analyzed DNA methylation patterns, focusing on developmentally relevant genes known to be targets of abnormal promoter DNA

Table 2 The top 20 genes that were most frequently gained, lost or showed no change in DNA methylation levels in the 120 ES cell lines analyzed at early and late passage

\begin{tabular}{lll}
\hline Gained DNA methylation & Lost DNA methylation & No change in DNA methylation \\
\hline GPC3 & CBLN4 & NR4A3 \\
RAB9B & HIST1H3C & EPHA4 \\
TCEAL4 & LY6H & COL12A1 \\
IL1RAPL2 & HIST1H4L & TIGD3 \\
ESX1 & ANKRD2OB & SNX7 \\
TCEAL3 & HIST1H4F & PIP5K1B \\
AMMECR1 & DMRT2 & KCNJ2 \\
MGC39900 & TTLL7 & T \\
LRCH2 & FOXD4L1 & ZBTB7A \\
ZCCHC12 & FOXD4L2 & IL2ORA \\
REPS2 & ONECUT1 & GNAO1 \\
SOX3 & MAL & EPB41L4A \\
RP13-360B22.2 & SYT6 & VDR \\
TSC22D3 & BHLHB4 & HS6ST3 \\
NHS & HIST1H3I & VGLL2 \\
TCEAL7 & XTP7 & SIX1 \\
MGC4825 & NEUROG1 & SFT2D2 \\
GPR50 & TFAP2D & BCAN \\
BCL2L10 & DRD5 & ELMOD1 \\
CDX4 & ASCL2 & PTGER4
\end{tabular}

GPC3 gained more than 5\% DNA methylation (range: $98-5 \%$ ) in over $70 \%$ of the samples analyzed, whereas CBLN4 lost more than 5\% DNA methylation (range: 70-5\%) in over $60 \%$ of them. The genes listed in the "No change" column showed fluctuations in DNA methylation $<1 \%$ in all samples profiled. methylation in cancer ${ }^{40}$, and thus most likely to be subjected to selection for altered expression during culture adaptation. For this we used a custom GoldenGate DNA methylation array developed to interrogate DNA methylation changes in known polycomb group protein $(\mathrm{PcG})$ targets in human ES cells ${ }^{53}$. In general, the DNA methylation patterns of the human ES cells tended to be unstable, with both increases or decreases depending upon the locus (Fig. 5 and Supplementary Data Set 4). Table 2 summarizes those genes that were most frequently subject to gain or loss of methylation during passage, or that showed the least change. Overall, we did not observe any hot spots for DNA methylation at the $\sim 1,500$ loci interrogated in the array used in this study, and chromosomes 12, 17 and 20 were not any more methylated, on average, than the rest of the genome.

As shown by cumulative distribution function (CDF) curves, most cell lines underwent extensive DNA methylation changes during their time in culture (Online Methods). However, there was a marked difference between the cell lines. For example, in some cell lines there were few changes observed even if there was a large difference in passage level between the early- and late-passage samples (Fig. 5 Q4 and Supplementary Table 3), whereas with other pairs there were large differences observed even when the passage-level difference between the samples was small (Fig. 5 Q1 and Supplementary Table 3). However, the causes of the variation in methylation stability between the lines were not evident. There was no obvious laboratory effect, and the karyotypically abnormal cell lines were not any more unstable than their karyotypically normal counterparts. This suggests that genetic instability played little to no role in the epigenetic instability of the cell lines analyzed. In addition, the DNA methylation patterns of the sibling ES cell lines were as different between themselves as they were between unrelated lines (Supplementary Data Set 4), suggesting that the genetic background of human ES cells plays a minor role in the degree of their epigenetic instability.

\section{DISCUSSION}

The occurrence of genetic and epigenetic change in human ES cells on prolonged passage is clearly important with respect to their use in regenerative medicine. Understanding the key genes involved and the mechanisms that drive change is important, not only for minimizing the impact of such variants in applications of ES and iPS cells, but also 
Figure 6 Recent pericentric inversion associated with $20 q 11.21$ susceptibility to gain. (a) The ancestral condition of chromosome 20 before a pericentric inversion in the last common ancestor of the gorilla, chimp and human. (b) Structure of human chromosome 20 with the location of the gap indicated in which the proximal end of all 20q11.21 amplicons lie.

for exploring the mechanisms that control the fate decisions of pluripotent cells between self-renewal, death and differentiation. Nevertheless, given the scale of the present study, it is striking that most of the ES cell lines studied (79/120 pairs, 66\%) remained karyotypically normal, even after many passages, whereas it was only with respect to chromosome 20 that evidence for structural variants in a specific region offering a strong selective advantage could be deduced. Among the small number of iPS cell samples studied, 3 out of 11 had abnormal karyotypes, with 1 of the 3 having the $20 \mathrm{q} 11$ gain in the late-passage sample.

Since the first reports of nonrandom chromosomal gain in human ES cells, many studies by standard karyology and by various molecular techniques, including CGH and SNP arrays, have found that, indeed, certain regions of the genome of both ES and, more recently, iPS cells are particularly subject to such genetic change upon prolonged passage in culture. Recently, it was also shown that iPS cells acquire mutations during their derivation, although many such mutations are lost on subsequent passaging ${ }^{54}$. It is commonly assumed that those genetic changes that repeatedly appear in pluripotent stem cells provide variant cells with a growth advantage, but the nature of the selective advantage is unclear. At the molecular karyotype level, it is difficult to disentangle changes that simply reflect variants existing in the human population from those acquired during culture. To address this, we explicitly sought to compare the genomes of a large set of human ES cell lines at two different passage levels and from as diverse a set as possible of the principal laboratories isolating these cells around the world. Although the number of human ES cell lines that have been derived worldwide is uncertain, the 125 ES cell lines analyzed in this study represent a substantial proportion of those commonly available. Notably, our data show that these lines include representatives of most major ethnic groups, reflecting far greater ethnic diversity than previously reported ${ }^{55,56}$.

One feature of the human genome emphasized by the current study is that some regions are especially dynamic, particularly but not exclusively those including repetitive elements. In the current panel of ES cells, many regions showed gains or losses between the passage levels, but with no consistency, suggesting that there is no common selection pressure driving the copy number changes. That such dynamically variable regions were readily detected suggests that human ES cell cultures may go through population size restrictions more often than appreciated. Indeed, the cell cycle time of human ES cells is about $18-20 \mathrm{~h}$, but common culture practice involves splitting cultures at low split ratios every $4-5 \mathrm{~d}$ or longer. This implies a very large proportion of undifferentiated cells, maybe as many as $90 \%$, are lost between passages of stock cultures ${ }^{33}$.

Likewise, the DNA methylation status of the ES cell lines also appeared to change dynamically. Although there was a marked increase in differential DNA methylation with time, indicated by the greater number of DNA methylation changes in the cell lines with the highest differences in passage number, there was also a substantial variation between lines that had undergone similar differences in passage numbers. Thus, human ES cells change not only genetically, but also epigenetically in culture. This conclusion is consistent with several other smaller scale studies that have interrogated human ES cells with respect to either general DNA methylation ${ }^{25}$, or imprinting ${ }^{29,31}$. These studies all found DNA methylation and imprinting changes that appeared to be variable between lines and were locus dependent. However, we could not identify specific recurring regions subject to methylation in the genome and there was no observed correlation between DNA methylation changes and chromosomal abnormalities. This suggests that, in general, changes in DNA methylation may be a dynamic process and not necessarily associated with adaptation as such. This point is reinforced by the observation that DNA methylation is markedly different between sibling lines.

In addition to these apparently stochastic and dynamic changes in the genome and epigenome, we did detect marked nonrandom changes in certain parts of the genome. The karyotypic changes seen in the current study match well with other published reports (Supplementary Fig. 5) ${ }^{1}$. Gains of chromosomes 1, 12, 17 and 20 and losses of chromosomes 10p and 18q are common in both data sets, and it is only gains of chromosomes 12, 17 and 20 that are often seen as a sole karyotypic change. However, recurrent deletion of chromosome $22 \mathrm{q}$ is a novel finding. On the other hand, the gain of chromosome $\mathrm{X}$ is a relatively common finding in published studies, whereas only two instances of gain and three instances of loss were observed in the present study. In the light of their relatively frequent occurrence, the minimal amplicons 1q21-qter, 12p11-pter, 17q25-qter and $20 \mathrm{q} 11.2$, and perhaps minimal deletions 10p13-pter, 18q21-qter and 22q13-qter deserve special attention as being likely to harbor genes of particular importance for the culture adaptation of human ES cells.

The frequent nonrandom gain of chromosomes 1, 12, 17 and 20 suggests that these chromosomes include a gene(s) that, when overexpressed, confers a growth advantage. Yet, it is striking that in our current extensive study, as in previous studies, structural variant analysis did not point to any frequent repetitive minimal amplicon occurring on chromosomes 1,12 and 17. Obvious candidate genes are located on these chromosomes-for example, NANOG on chromosome 12but none seems to be more subject to structural variants than other genes on these chromosomes in the absence of karyotypic change. We did see gains spanning the neighboring SLC2A3/NANOGP1 region described in a recent study ${ }^{46}$ but this is just as prevalent, if not more so, within our reference samples and spread across most major ethnic groups, suggesting it is a common structural variant in the human population rather than specific to human ES cells. Together, these observations suggest that the selective advantage attributable to the 
gain of chromosomes 1, 12 and 17 may depend upon overexpression of genes or genetic elements at multiple, spatially separated loci, or upon the combination of a structural gene with a long range cis-acting regulatory element such that both units must be amplified together to yield an increased function. Alternatively, the appearance of gains within smaller regions may be restricted by chromosomal structure less susceptible to this form of mutation.

By contrast, and in agreement with other studies $5,10,11,23,46,57$, our karyotypic and structural variant data point to a region (20q11.21) that, when amplified, apparently drives selection. In this study, because of the much larger number of cell lines and our ability to compare early and late passage, we were able to map the gain to a specific region. Other studies have also reported that gains in this region are associated with enhanced growth characteristics ${ }^{23}$, and at least some of the lines in the present study were reported by their contributors to have increased population growth rates (data not shown). The frequency of this gain (25\% of the karyotypically normal cell lines), combined with the enrichment in late-passage samples, clearly indicates its selective advantage in human ES cell culture. The mechanism for the selective advantage presumably lies in the minimal region shared by all 22 affected lines, a region containing 13 genes, only three of which are known to be expressed in human ES cells: HM13, ID1 and BCL2L1.

A recent genome-wide RNA interference (RNAi) screen highlights the functional importance of $B C L 2 L 1$, an anti-apoptotic factor, in human ES cell biology ${ }^{58}$. This RNAi screen ranked BCL2L1 twentysecond of 21,121 genes in reducing proliferation after knockdown, whereas HM13 and ID1 were ranked $6,679^{\text {th }}$ and $4,224^{\text {th }}$, respectively ${ }^{58}$. Additionally, a recent structural variant screen of $>3,000$ specimens from two dozen cancer cell types similarly identified a reoccurring gain on $20 \mathrm{q} 11.21$ in which BCL2L1 was also contained within the minimal amplicon, and knockdown experiments indicated a role for BCL2L1 in cancer cell proliferation ${ }^{59}$. Recently, it has also been reported that overexpression of the related anti-apoptotic gene, $B C L 2$, enhances the survival of human ES cells ${ }^{60}$, although $B C L 2$ is encoded with the region of chromosome 18 subject to recurrent loss in the current data set. Taken together, these observations suggest that similar mutations shared between ES and cancer cells lead to a selective advantage during clonal evolution. The temporal component of our study, where we see ${ }^{17}$ instances of early/normal to late/ mutated transitions, provides additional support for the notion that the $20 \mathrm{q} 11.21$ mutation is the driver mutation in the clonal evolution of these adapted stem cells. Although a role for ID1 (ref. 61) and HM13 cannot be excluded, enhanced cell survival due to elevated expression levels of $B C L 2 L 1$ offers the most likely mechanism.

The repeated appearance of a structural variant across multiple lines requires both a selective advantage for the variant (e.g., increased expression of $B C L 2 L 1$ ), and a predisposition for the respective mutation to occur. It is noteworthy that the proximal end of all human ES cell $20 \mathrm{q} 11.21$ gains lies within a gap region of the current human assembly $^{62}$. The presumption is that the highly repetitive sequence within this gap predisposes the region to structural rearrangement. With the link between genome rearrangements, primate evolution and disease association $^{63}$, it is notable that this gap coincides with a recent chromosomal rearrangement, a pericentric inversion ${ }^{64}$, occurring in the last common ancestor of gorilla, chimp and human (Fig. 6). The gap region, possibly a centromeric remnant of a tandem duplication ${ }^{62}$, introduces the repetitive sequence creating 20q11.21 rearrangement (or amplification) susceptibility. The frequency of appearance that is created by this combination of mutability and the decreased apoptosis warrants routine surveillance similar to that now done in karyotypic analysis.
The identification of genes that drive both cancer progression of EC cells in germ cell tumors and the progressive culture adaptation of ES cells has been a goal since the first clear recognition that gain of sections of the short arm of chromosome 12 is an invariant feature of EC cells $^{14}$. The commonality of the changes in the tumors and in the ES cell in culture suggests common underlying mechanisms. However, the identification of a specific driver gene on chromosomes 1, 12 and 17 has been elusive, suggesting that more than one gene may be involved in the growth advantage of the aneuploid cells. Our present results now point to a specific gene subject to gain, most likely the anti-apoptotic gene, $B C L 2 L 1$, on chromosome 20 , that may promote the survival of ES cells in vitro and EC cells in vivo, thereby providing a strong growth advantage, whether in cancers or in vitro.

\section{METHODS}

Methods and any associated references are available in the online version of the paper at http://www.nature.com/naturebiotechnology/.

Note: Supplementary information is available on the Nature Biotechnology website.

\section{ACKNOWLEDGMENTS}

The International Stem Cell Initiative is funded by The International Stem Cell Forum. The authors would like to acknowledge the following: Medical Research Council, UK (P.W.A., H.M.); Mohammad Pakzad \& Adeleh Taei, Royan Institute (H.B., G.H.S.); California Institute for Regenerative Medicine (CIRM) (E.C., P.W.L.); Institute of Medical Biology, A*STAR, Singapore (J.M.C.); Ministry of Education, Youth and Sports of the Czech Republic (P.D., A.H.); Stem Cell Research Center of the 21st Century Frontier Research Program, Ministry of Education, Science \& Technology, Republic of Korea (SC-1140) (D.R.L., S.K.O.); Ministry of Science and Technology of China (863 program 2006AA02A102) (L.G.); Swedish Research Council, Cellartis (O.H.); Department of Biotechnology, Government of India, UK-India Education and Research Initiative and the Jawaharlal Nehru Centre for Advanced Scientific Research, Bangalore, India (M.I.); Program for Promotion of Fundamental Studies in Health Sciences of the National Institute of Biomedical Innovation, Leading Project of the Ministry of Education, Culture, Sports, Science and Technology (MEXT), Funding Program for WorldLeading Innovative R\&D on Science and Technology (FIRST Program) of the Japan Society for the Promotion of Science (JSPS), Grants in-Aid for Scientific Research of JSPS and MEXT (T.I., S.Y., K.T.); Swiss National Science Foundation (grant no. 4046-114410) (M.J.); Shanghai Science and Technology Developmental Foundation (06DJ14001), Chinese Ministry of Science and Technology (2007CB948004) (Y.J.); funding from the North West Science Fund, UK (S.K.); One North East Regional Developmental Agency, Medical Research Council, UK, Newcastle University (M.L.); research funding from the Australian Stem Cell Centre (A.L.L.); The Netherlands Proteomics Consortium grant T4-3 (C.M.); Stem Cell Network, Canada (A.N.); National BioResource Project, MEXT, Japan (N.N.); Singapore Stem Cell Consortium (SSCC) \& the Agency for Science Technology and Research (A*STAR) (S.K.W.O., P.R.) and the Genome Institute of Singapore Core Genotyping Lab (P.R.); Academy of Finland, Sigrid Juselius Foundation (T.O.); Conselho Nacional de Desenvolvimento Científico e Tecnológico/Departamento de Ciência e Tecnologia do Ministério da Saúde (CNPq/MS/DECIT), and Fundação de Amparo à Pesquisa do Estado de São Paulo (FAPESP) (L.V.P.); supported by the kind donation of Judy and Sidney Swartz (B.R.); financial support from the Faculty of Medicine, University of New South Wales (UNSW) and the National Health and Medical Research Council (NHMRC) Program Grant no. 568969 (Perminder Sachdev), South Eastern Sydney and Illawarra Area Health Service (SEIAHS) for making hES cell line Endeavour-2 available for this study, and H. Chung and J. Kim for their help in preparing the samples (K.S.); Academy of Finland (grant 218050), the Competitive Research Funding of the Tampere University Hospital (grant 9F217) (H. Skottman).

\section{AUTHOR CONTRIBUTIONS}

Project coordination: P.W.A. Cytogenetic analyses: D.B., A.D., E.M., K.D.M. and T.G.-L. Molecular karyotyping by SNP BeadChip: P.R. DNA methylation arrays: R.M.B. and P.W.L. Administration and data curation: A. Ford and P.J.G. Data analysis and manuscript drafting: P.W.A., S.A., D.B., N.B., R.M.B., P.J.G., K.H., L.H., B.B.K., Y. Mayshar, S.K.W.O., M.F.P. and P.R. The scientific management of the ISCI project was provided by a steering committee comprising: P.W.A., N.B., B.B.K., S.K.W.O., M.F.P., J.R. and G.N.S. Sample contribution: A. Colman, A. Robins, A. Hampl, A. Bosman, A.M. Fraga, A. Nagy, A.B.H. Choo, A.L. Laslett, A. Feki, A. Kuliev, A. Kresentia Irwanto, B. Reubinoff, B. Sun, C. Denning, 
C. Mummery, C. Li, C. Olson, C. Spits, D. Ben-Yosef, D. Collins, D.J. Weisenberger, D. Ryul Lee, D. Ward-van Oostwaard, E. Chiao, E. Sherrer, Fei Pan, F. Holm, G. Anyfantis, G.Q. Daley, G.H. Salekdeh, G. Selva Raj, G. Caisander, H. Gourabi, H. Moore, H. Skottman, H. Suemori, H. Baharvand, H. Shen, I. Mateizel, In-Hyun Park, J. Sheik Mohamed, J. Downie, J. Eun Lee, J.M. Crook, J. Chen, J. Hyllner, J.-C. Biancotti, J. Baker, K. Sermon, K. Amps, K. Narwani, K. Takahashi, K. Sidhu, L. Ge, L.S. Lim, L. Young, Q. Zhou, L. Guangxiu, L.V. Pereira, L. Armstrong, M. Lako, M.S. Inamdar, M.A. Lagarkova, M.B. Munoz, M. Mileikovsky, M.V. Camarasa, M. Jaconi, M. Gropp, N. Lavon, N. Strelchenko, N. Nakatsuji, O. Kopper, O. Hovatta, O. Qi, P. Venu, P.A. De Sousa, P. Dvorak, R. Strehl, R. Suuronen, S. Kiselev, S. Yong Moon, S. Yamanaka, S. Sivarajah, S. Beil, S.L. Minger, S.K.W. Oh, S. Pells, S. Kyung Oh, S. Kimber, T. Miyazaki, T.E. Ludwig, T. Ishii, T.C. Schulz, T. Otonkoski, T. Tuuri, T. Frumkin, V. Kukharenko, V. Fox, W. Herath, Y. Jin, Y. Min Choi, Y. Ma, Y. Wu and Y. Verlinsky.

\section{COMPETING FINANCIAL INTERESTS}

The authors declare competing financial interests: details accompany the full-text HTML version of the paper at http://www.nature.com/nbt/index.html.

Published online at http://www.nature.com/nbt/index.html.

Reprints and permissions information is available online at http://www.nature.com/ reprints/index.html.

1. Baker, D.E. et al. Adaptation to culture of human embryonic stem cells and oncogenesis in vivo. Nat. Biotechnol. 25, 207-215 (2007).

2. Draper, J.S. et al. Recurrent gain of chromosomes $17 \mathrm{q}$ and 12 in cultured human embryonic stem cells. Nat. Biotechnol. 22, 53-54 (2004).

3. Mitalipova, M.M. et al. Preserving the genetic integrity of human embryonic stem cells. Nat. Biotechnol. 23, 19-20 (2005).

4. Hoffman, L.M. \& Carpenter, M.K. Characterization and culture of human embryonic stem cells. Nat. Biotechnol. 23, 699-708 (2005).

5. Maitra, A. et al. Genomic alterations in cultured human embryonic stem cells. Nat. Genet. 37, 1099-1103 (2005)

6. Buzzard, J.J., Gough, N.M., Crook, J.M. \& Colman, A. Karyotype of human ES cells during extended culture. Nat. Biotechnol. 22, 381-382, author reply 382 (2004).

7. Caisander, G. et al. Chromosomal integrity maintained in five human embryonic stem cell lines after prolonged in vitro culture. Chromosome Res. 14, 131-137 (2006).

8. Inzunza, J. et al. Comparative genomic hybridization and karyotyping of human embryonic stem cells reveals the occurrence of an isodicentric $\mathrm{X}$ chromosome after long-term cultivation. Mol. Hum. Reprod. 10, 461-466 (2004).

9. Rosler, E.S. et al. Long-term culture of human embryonic stem cells in feeder-free conditions. Dev. Dyn. 229, 259-274 (2004).

10. Lefort, N. et al. Human embryonic stem cells reveal recurrent genomic instability at 20q11.21. Nat. Biotechnol. 26, 1364-1366 (2008).

11. Spits, C. et al. Recurrent chromosomal abnormalities in human embryonic stem cells. Nat. Biotechnol. 26, 1361-1363 (2008).

12. Mayshar, Y. et al. Identification and classification of chromosomal aberrations in human induced pluripotent stem cells. Cell Stem Cell 7, 521-531 (2010).

13. Wang, N., Trend, B., Bronson, D.L. \& Fraley, E.E. Nonrandom abnormalities in chromosome 1 in human testicular cancers. Cancer Res. 40, 796-802 (1980).

14. Atkin, N.B. \& Baker, M.C. Specific chromosome change, i(12p), in testicular tumours? Lancet 320, 1349 (1982).

15. Rodriguez, E. et al. Molecular cytogenetic analysis of i(12p)-negative human male germ cell tumors. Genes Chromosom. Cancer 8, 230-236 (1993).

16. Skotheim, R.I. et al. New insights into testicular germ cell tumorigenesis from gene expression profiling. Cancer Res. 62, 2359-2364 (2002).

17. Mostert, M. et al. Comparative genomic and in situ hybridization of germ cell tumors of the infantile testis. Lab. Invest. 80, 1055-1064 (2000).

18. Schneider, D.T. et al. Genetic analysis of childhood germ cell tumors with comparative genomic hybridization. Klin. Padiatr. 213, 204-211 (2001).

19. Looijenga, L.H. et al. Comparative genomic hybridization of microdissected samples from different stages in the development of a seminoma and a non-seminoma. J. Pathol. 191, 187-192 (2000).

20. Longo, L., Bygrave, A., Grosveld, F.G. \& Pandolfi, P.P. The chromosome make-up of mouse embryonic stem cells is predictive of somatic and germ cell chimaerism. Transgenic Res. 6, 321-328 (1997)

21. Liu, X. et al. Trisomy eight in ES cells is a common potential problem in gene targeting and interferes with germ line transmission. Dev. Dyn. 209, 85-91 (1997).

22. Zody, M.C. et al. DNA sequence of human chromosome 17 and analysis of rearrangement in the human lineage. Nature 440, 1045-1049 (2006).

23. Werbowetski-Ogilvie, T.E. et al. Characterization of human embryonic stem cells with features of neoplastic progression. Nat. Biotechnol. 27, 91-97 (2009).

24. Narva, E. et al. High-resolution DNA analysis of human embryonic stem cell lines reveals culture-induced copy number changes and loss of heterozygosity. Nat. Biotechnol. 28, 371-377 (2010).

25. Allegrucci, C. et al. Restriction landmark genome scanning identifies cultureinduced DNA methylation instability in the human embryonic stem cell epigenome. Hum. Mol. Genet. 16, 1253-1268 (2007).

26. Calvanese, V. et al. Cancer genes hypermethylated in human embryonic stem cells. PLOS ONE 3, e3294 (2008).
27. Enver, T. et al. Cellular differentiation hierarchies in normal and culture-adapted human embryonic stem cells. Hum. Mol. Genet. 14, 3129-3140 (2005).

28. Rugg-Gunn, P.J., Ferguson-Smith, A.C. \& Pedersen, R.A. Epigenetic status of human embryonic stem cells. Nat. Genet. 37, 585-587 (2005).

29. Adewumi, 0. et al. Characterization of human embryonic stem cell lines by the International Stem Cell Initiative. Nat. Biotechnol. 25, 803-816 (2007)

30. Rugg-Gunn, P.J., Ferguson-Smith, A.C. \& Pedersen, R.A. Status of genomic imprinting in human embryonic stem cells as revealed by a large cohort of independently derived and maintained lines. Hum. Mol. Genet. 16Spec No. 2, R243-R251 (2007).

31. Kim, K.P. et al. Gene-specific vulnerability to imprinting variability in human embryonic stem cell lines. Genome Res. 17, 1731-1742 (2007).

32. Andrews, P.W. et al. The International Stem Cell Initiative: toward benchmarks for human embryonic stem cell research. Nat. Biotechnol. 23, 795-797 (2005)

33. Olariu, V. et al. Modeling the evolution of culture-adapted human embryonic stem cells. Stem Cell Res. 4, 50-56 (2010).

34. Martin, G.R. \& Evans, M.J. The morphology and growth of a pluripotent teratocarcinoma cell line and its derivatives in tissue culture. Cell 2, 163-172 (1974).

35. Andrews, P.W., Bronson, D.L., Benham, F., Strickland, S. \& Knowles, B.B. A comparative study of eight cell lines derived from human testicular teratocarcinoma. Int. J. Cancer 26, 269-280 (1980).

36. Chambers, I. et al. Functional expression cloning of Nanog, a pluripotency sustaining factor in embryonic stem cells. Cell 113, 643-655 (2003).

37. Mitsui, K. et al. The homeoprotein Nanog is required for maintenance of pluripotency in mouse epiblast and ES cells. Cell 113, 631-642 (2003).

38. Darr, H., Mayshar, Y. \& Benvenisty, N. Overexpression of NANOG in human ES cells enables feeder-free growth while inducing primitive ectoderm features. Development 133, 1193-1201 (2006).

39. Korkola, J.E. et al. Down-regulation of stem cell genes, including those in a $200-\mathrm{kb}$ gene cluster at $12 \mathrm{p} 13.31$, is associated with in vivo differentiation of human male germ cell tumors. Cancer Res. 66, 820-827 (2006).

40. Widschwendter, M. et al. Epigenetic stem cell signature in cancer. Nat. Genet. 39 157-158 (2007).

41. Frazer, K.A. et al. A second generation human haplotype map of over 3.1 million SNPs. Nature 449, 851-861 (2007).

42. Li, J.Z. et al. Worldwide human relationships inferred from genome-wide patterns of variation. Science 319, 1100-1104 (2008).

43. Abdulla, M.A. et al. Mapping human genetic diversity in Asia. Science 326 , 1541-1545 (2009).

44. Pritchard, J.K., Stephens, M. \& Donnelly, P. Inference of population structure using multilocus genotype data. Genetics 155, 945-959 (2000).

45. Novembre, J. et al. Genes mirror geography within Europe. Nature 456, 98-101 (2008)

46. Laurent, L.C. et al. Dynamic changes in the copy number of pluripotency and cell proliferation genes in human ESCS and iPSCs during reprogramming and time in culture. Cell Stem Cell 8, 106-118 (2011).

47. Wang, K. et al. PennCNV: an integrated hidden Markov model designed for highresolution copy number variation detection in whole-genome SNP genotyping data. Genome Res. 17, 1665-1674 (2007).

48. Assou, S. et al. A meta-analysis of human embryonic stem cells transcriptome integrated into a web-based expression atlas. Stem Cells 25, 961-973 (2007).

49. Peng, J.C. et al. Jarid2/Jumonji coordinates control of PRC2 enzymatic activity and target gene occupancy in pluripotent cells. Cell 139, 1290-1302 (2009).

50. Nottke, A., Colaiacovo, M.P. \& Shi, Y. Developmental roles of the histone lysine demethylases. Development 136, 879-889 (2009).

51. Morin, R.D. et al. Application of massively parallel sequencing to microRNA profiling and discovery in human embryonic stem cells. Genome Res, 18, 610-621 (2008).

52. Bai, H. et al. Bcl-xL enhances single-cell survival and expansion of human embryonic stem cells without affecting self-renewal. Stem Cell Res. (Amst.) (in the press).

53. Lee, T.I. et al. Control of developmental regulators by Polycomb in human embryonic stem cells. Cell 125, 301-313 (2006)

54. Hussein, S.M. et al. Copy number variation and selection during reprogramming to pluripotency. Nature 471, 58-62 (2011).

55. Mosher, J.T. et al. Lack of population diversity in commonly used human embryonic stem-cell lines. N. Engl. J. Med. 362, 183-185 (2010)

56. Laurent, L.C. et al. Restricted ethnic diversity in human embryonic stem cell lines. Nat. Methods 7, 6-7 (2010).

57. Wu, H. et al. Copy number variant analysis of human embryonic stem cells Stem Cells 26, 1484-1489 (2008).

58. Chia, N.Y. et al. A genome-wide RNAi screen reveals determinants of human embryonic stem cell identity. Nature 468, 316-320 (2010).

59. Beroukhim, R. et al. The landscape of somatic copy-number alteration across human cancers. Nature 463, 899-905 (2010).

60. Ardehali, R. et al. Overexpression of BCL2 enhances survival of human embryonic stem cells during stress and obviates the requirement for serum factors. Proc. Natl. Acad. Sci. USA 108, 3282-3287 (2011).

61. Martins-Taylor, K. et al. Recurrent copy number variations in human induced pluripotent stem cells. Nat. Biotechnol. 29, 488-491 (2011).

62. Deloukas, P. et al. The DNA sequence and comparative analysis of human chromosome 20. Nature 414, 865-871 (2001).

63. Shaw, C.J. \& Lupski, J.R. Implications of human genome architecture for rearrangement-based disorders: the genomic basis of disease. Hum. Mol. Genet. 13 Spec No 1, R57-R64 (2004).

64. Misceo, D. et al. Evolutionary history of chromosome 20. Mol. Biol. Evol. 22, 360-366 (2005). 
Katherine Amps ${ }^{1}$, Peter W Andrews ${ }^{1}$, George Anyfantis ${ }^{2}$, Lyle Armstrong ${ }^{2}$, Stuart Avery ${ }^{3}$, Hossein Baharvand ${ }^{4}$, Julie Baker ${ }^{5}$, Duncan Baker ${ }^{6}$, Maria B Munoz ${ }^{7}$, Stephen Beil ${ }^{8}$, Nissim Benvenisty ${ }^{9}$, Dalit Ben-Yosef ${ }^{10,11}$, Juan-Carlos Biancotti ${ }^{12}$, Alexis Bosman ${ }^{13}$, Romulo Martin Brena ${ }^{14}$, Daniel Brison ${ }^{15}$, Gunilla Caisander ${ }^{16}$, María V Camarasa ${ }^{17}$, Jieming Chen ${ }^{18}$, Eric Chiao ${ }^{5,19}$, Young Min Choi ${ }^{20}$, Andre B H Choo ${ }^{21}$, Daniel Collins ${ }^{22}$, Alan Colman ${ }^{3,23}$, Jeremy M Crook ${ }^{3,23-26}$, George Q Daley ${ }^{27-30}$, Anne Dalton ${ }^{6}$, Paul A De Sousa ${ }^{22,31}$, Chris Denning ${ }^{7}$, Janet Downie ${ }^{22}$, Petr Dvorak ${ }^{32}$, Karen D Montgomery ${ }^{33}$, Anis Feki ${ }^{34}$, Angela Ford ${ }^{1}$, Victoria Fox ${ }^{8}$, Ana M Fraga ${ }^{35}$, Tzvia Frumkin ${ }^{10}$, Lin Ge ${ }^{36}$, Paul J Gokhale ${ }^{1}$, Tamar Golan-Lev ${ }^{9}$, Hamid Gourabi ${ }^{4}$, Michal Gropp ${ }^{37}$, Lu Guangxiu ${ }^{36}$, Ales Hampl ${ }^{38,39}$, Katie Harron ${ }^{40}$, Lyn Healy ${ }^{41}$, Wishva Herath ${ }^{18}$, Frida Holm ${ }^{42}$, Outi Hovatta $^{42}$, Johan Hyllner ${ }^{16}$, Maneesha S Inamdar ${ }^{43}$, Astrid Kresentia Irwanto ${ }^{18}$, Tetsuya Ishii ${ }^{44,73}$, Marisa Jaconi ${ }^{13}$, Ying Jin ${ }^{45}$, Susan Kimber ${ }^{17}$, Sergey Kiselev ${ }^{46,47}$, Barbara B Knowles ${ }^{3}$, Oded Kopper ${ }^{9}$, Valeri Kukharenko ${ }^{48}$, Anver Kuliev ${ }^{48}$, Maria A Lagarkova ${ }^{47}$, Peter W Laird ${ }^{14}$, Majlinda Lako ${ }^{2}$, Andrew L Laslett ${ }^{49,50}$, Neta Lavon ${ }^{12}$, Dong Ryul Lee ${ }^{51}$, Jeoung Eun Lee ${ }^{52}$, Chunliang Li ${ }^{53}$, Linda S Lim ${ }^{18}$, Tenneille E Ludwig ${ }^{33}$, Yu Ma ${ }^{53}$, Edna Maltby ${ }^{6}$, Ileana Mateizel ${ }^{54}$, Yoav Mayshar ${ }^{9}$, Maria Mileikovsky ${ }^{55}$, Stephen L Minger ${ }^{56,57}$, Takamichi Miyazaki ${ }^{58}$, Shin Yong Moon ${ }^{20}$, Harry Moore ${ }^{1}$, Christine Mummery ${ }^{59}$, Andras $\mathrm{Nagy}^{55}$, Norio Nakatsuji ${ }^{60}$, Kavita Narwani ${ }^{12}$, Steve K W Oh${ }^{21}$, Sun Kyung $\mathrm{Oh}^{61}$, Cia Olson ${ }^{62}$, Timo Otonkoski ${ }^{62,63}$, Fei Pan ${ }^{14}$, In-Hyun Park ${ }^{64}$, Steve Pells ${ }^{31}$, Martin F Pera ${ }^{65}$, Lygia V Pereira ${ }^{35}$, Ouyang Qi ${ }^{36}$, Grace Selva Raj ${ }^{23}$, Benjamin Reubinoff ${ }^{37}$, Alan Robins ${ }^{66}$, Paul Robson ${ }^{18}$, Janet Rossant ${ }^{67}$, Ghasem H Salekdeh ${ }^{68}$, Thomas C Schulz ${ }^{66}$, Karen Sermon ${ }^{54}$, Jameelah Sheik Mohamed ${ }^{18}$, Hui Shen ${ }^{14}$, Eric Sherrer ${ }^{66}$, Kuldip Sidhu ${ }^{69}$, Shirani Sivarajah ${ }^{23-25}$, Heli Skottman ${ }^{70}$, Claudia Spits ${ }^{54}$, Glyn N Stacey ${ }^{41}$, Raimund Strehl ${ }^{16}$, Nick Strelchenko ${ }^{48,73}$, Hirofumi Suemori ${ }^{58}$, Bowen Sun ${ }^{53}$, Riitta Suuronen ${ }^{70}$, Kazutoshi Takahashi ${ }^{44}$, Timo Tuuri ${ }^{62}$, Parvathy Venu ${ }^{43}$, Yuri Verlinsky ${ }^{48,74}$, Dorien Ward-van Oostwaard ${ }^{59}$, Daniel J Weisenberger ${ }^{14}$, Yue Wu ${ }^{56,57}$, Shinya Yamanaka ${ }^{44,60,71,72}$, Lorraine Young $^{7}$ \& Qi Zhou ${ }^{49}$

${ }^{1}$ Centre for Stem Cell Biology, Department of Biomedical Science, The University of Sheffield, Sheffield, UK. ${ }^{2}$ North East England Stem Cell Institute at Life, International Centre for Life, Newcastle upon Tyne, UK. ${ }^{3}$ Institute of Medical Biology, A-STAR, Immunos, Singapore. ${ }^{4}$ Royan Institute for Reproductive Biomedicine, Department of Genetics, Tehran, Islamic Republic of Iran. ${ }^{5}$ Stanford University, Stanford, California, USA. ${ }^{6}$ Sheffield Diagnostic Genetic Services, Sheffield Children's NHS Trust, Sheffield, UK. ${ }^{7}$ Wolfson Centre for Stem Cells, Tissue Engineering \& Modelling (STEM), Centre for Biomolecular Sciences, University of Nottingham, UK. ${ }^{8}$ USC Stem Cell Core Facility, The Eli and Edythe Broad Center for Regenerative Medicine and Stem Cell Research at USC, Keck School of Medicine, University of Southern California, Los Angeles, California, USA. ${ }^{9}$ Stem Cell Unit, Department of Genetics, Silberman Institute of Life Sciences, The Hebrew University of Jerusalem, Edmond J. Safra Campus, Givat Ram, Jerusalem, Israel. ${ }^{10}$ Racine IVF Unit, Lis Maternity Hospital, Tel Aviv Sourasky Medical Center, Tel Aviv, Israel. ${ }^{11}$ Department of Cell Developmental Biology, Sackler Faculty of Medicine, Tel Aviv University, Tel Aviv, Israel. ${ }^{12}$ Regenerative Medicine Institute, Cedars-Sinai Medical Institute, Los Angeles, California, USA. ${ }^{13}$ Department of Pathology and Immunology, Faculty of Medicine, Geneva University, Geneva, Switzerland. 14USC Epigenome Center, Keck School of Medicine, University of Southern California, Los Angeles, California, USA. ${ }^{15}$ Department of Reproductive Medicine, St. Marys's Hospital, Central Manchester NHS Foundation Trust, Manchester Academic Health Sciences Centre, Manchester, UK. ${ }^{16}$ Cellartis AB, Goteborg, Sweden. ${ }^{17}$ Faculty of Life Sciences, University of Manchester, Manchester, UK. ${ }^{18}$ Genome Institute of Singapore, Singapore. ${ }^{19}$ Hoffmann-LaRoche, Nutley, New Jersey, USA. ${ }^{20}$ Department of Obstetrics \& Gynaecology, Seoul National University College of Medicine, Seoul, Republic of Korea. ${ }^{21}$ Bioprocessing Technology Institute, Singapore. ${ }^{22}$ Roslin Cells Ltd., Roslin Biocentre, Roslin, Midlothian, UK. ${ }^{23}$ Singapore Stem Cell Consortium, A-STAR, Singapore. ${ }^{24}$ Centre for Neural Engineering, The University of Melbourne, Parkville, Australia. ${ }^{25}$ Optics and Nanoelectronics Research Group, NICTA Victorian Research Laboratory, The University of Melbourne, Parkville, Australia. ${ }^{26}$ Department of Surgery, St. Vincent's Hospital, The University of Melbourne, Fitzroy, Australia. ${ }^{27}$ Stem Cell Transplantation Program, Division of Pediatric Hematology/Oncology, Manton Center for Orphan Disease Research, Howard Hughes Medical Institute, Children's Hospital Boston and Dana-Farber Cancer Institute, Boston, Massachusetts, USA. ${ }^{28}$ Division of Hematology, Brigham and Women's Hospital, Boston, Massachusetts, USA. ${ }^{29}$ Department of Biological Chemistry and Molecular Pharmacology, Harvard Medical School, Boston, Massachusetts, USA. ${ }^{30}$ Harvard Stem Cell Institute, Boston, Massachusetts, USA. ${ }^{31}$ Medical Research Council Centre for Regenerative Medicine, University of Edinburgh, Edinburgh, UK. ${ }^{32}$ Department of Biology, Faculty of Medicine, Masaryk University, Brno, Czech Republic. ${ }^{33}$ WiCell Research Institute, Madison, Wisconsin, USA. ${ }^{34}$ Department of Obstetrics and Gynecology, Hopital Cantonal Fribourgois, Freibourg, Switzerland. ${ }^{35}$ National Laboratory for Embryonic Stem Cell Research (LaNCE), Department of Genetics and Evolutionary Biology, University of São Paulo, São Paulo, Brazil. 36Institute of Reproductive \& Stem Cell Engineering, Central South University, Reproductive \& Genetic Hospital CITIC-XIANGYA, Changsha, Hunan, People's Republic of China. ${ }^{37}$ The Hadassah Human Embryonic Stem Cell Research Center, The Goldyne Savad Institute of Gene Therapy, Hadassah University Medical Center, Jerusalem, Israel. ${ }^{38}$ Department of Histology and Embryology, Faculty of Medicine, Masaryk University, Brno, Czech Republic. ${ }^{39}$ Institute of Experimental Medicine ASCR, Prague, Czech Republic. ${ }^{40}$ MRC Centre of Epidemiology for Child Health, Institute of Child Health, University College London, London, UK. ${ }^{41}$ UK Stem Cell Bank, Division of Cell Biology and Imaging, National Institute for Biological Standards and Control, South Mimms, Herts, UK. ${ }^{42}$ Department of Clinical Science, Intervention and Technology, Karolinska Institutet, Karolinska University Hospital Huddinge, Stockholm, Sweden. ${ }^{43}$ Jawaharlal Nehru Centre for Advanced Scientific Research, Bangalore, India. ${ }^{44}$ Center for iPS Cell Research and Application (CiRA), Kyoto University, Kyoto, Japan. ${ }^{45}$ Key Laboratory of Stem Cell Biology, Institute of Health Sciences, Shanghai Institutes of Biological Sciences, CAS/Shanghai JiaoTong University School of Medicine, Shanghai, People's Republic of China. ${ }^{46}$ Stem Cell Department, NRC Kurchatov Institute, Moscow, Russia. ${ }^{47}$ Vavilov Institute of General Genetics, Moscow, Russia. ${ }^{48}$ Reproductive Genetics Institute, Chicago, IIlinois, USA. ${ }^{49}$ CSIRO Material Science and Engineering, Clayton, Australia. ${ }^{50}$ Department of Anatomy and Developmental Biology, Monash University, Clayton, Australia. ${ }^{51}$ Department of Biomedical Science, CHA Stem Cell Institute, CHA University, Gangnam-gu, Seoul, Republic of Korea. ${ }^{52} \mathrm{CHA}$ Stem Cell Institute, CHA University, Gangnam-gu, Seoul, Republic of Korea. ${ }^{53}$ Shanghai Stem Cell Institute, Shanghai JiaoTong University School of Medicine, Shanghai, People's Republic of China. ${ }^{54}$ Department of Embryology and Genetics, Vrije Universiteit Brussel, Brussels, Belgium. ${ }^{55}$ Samuel Lunenfeld Research Institute, Mount Sinai Hospital, Toronto, Ontario, Canada. ${ }^{56}$ Wolfson Centre for AgeRelated Diseases, King's College London, London, UK. ${ }^{57}$ GE Healthcare, Cardiff, UK. ${ }^{58}$ Laboratory of Embryonic Stem Cell Research, Stem Cell Research Center, Institute for Frontier Medical Sciences, Kyoto University, Kyoto, Japan. ${ }^{59}$ Department of Anatomy \& Embryology, Leiden University Medical Center, Leiden, The Netherlands. ${ }^{60}$ Institute for Integrated Cell-Material Sciences, Kyoto University, Ushinomiya-cho, Yoshida, Sakyo-ku, Kyoto, Japan. ${ }^{61}$ Institute of Reproductive Medicine \& Population, Medical Research Center, Seoul National University, Seoul, Republic of Korea. ${ }^{62}$ Research Programs Unit, Molecular Neurology, Biomedicum Stem Cell Centre, University of Helsinki, Finland. ${ }^{63}$ Children's Hospital, University of Helsinki and Helsinki University Central Hospital, Finland. ${ }^{64}$ Department of 
Genetics, Yale Stem Cell Center, Yale School of Medicine, New Haven, Connecticut, USA. ${ }^{65}$ The Eli and Edythe Broad Center for Regenerative Medicine and Stem Cell Research at USC, Keck School of Medicine, University of Southern California, Los Angeles, California, USA. ${ }^{66}$ Viacyte, Athens, Georgia, USA. ${ }^{67}$ Program for Developmental Biology, The Hospital for Sick Children, Toronto, Ontario, Canada. ${ }^{68}$ Department of Molecular Systems Biology, Cell Science Research Center, Royan Institute for Stem Cell Biology and Technology, ACECR, Tehran, Islamic Republic of Iran. ${ }^{69}$ Stem Cell Laboratory, Faculty of Medicine, University of New South Wales, Australia. ${ }^{70}$ Institute for Regenerative Medicine, University of Tampere, Tampere, Finland. ${ }^{71}$ Yamanaka iPS Cell Special Project, Japan Science and

Technology Agency, Kawaguchi, Japan. ${ }^{72}$ Gladstone Institute of Cardiovascular Disease, San Francisco, California, USA. ${ }^{73}$ Present addresses: Japan Science and Technology Agency, Tokyo, Japan (T. Ishii) and Department of Obstetrics and Gynecology, New York University Langone Medical Center, New York, New York, USA (N. Strelchenko). ${ }^{74}$ Deceased. 


\section{ONLINE METHODS}

Design of study. Laboratories that agreed to contribute cell lines to the study were asked to provide four preparations of DNA from a culture of each cell line to be analyzed, two preparations from as early a passage as possible and two from as late a passage as possible (Supplementary Note 1, protocol for DNA preparation). The samples were coded and shipped directly, one pair of early- and late-passage DNA for SNP analysis to the Genome Institute, $A^{*}$ STAR, Singapore, and one pair of samples for DNA methylation analysis to the University of Southern California. The laboratories were also asked to prepare fixed hypotonic-treated samples of cells at both passage levels, following culture in colcemid, according to a specified protocol (Supplementary Note 2). These samples were shipped to the University of Sheffield for preparation and karyotypic analysis of metaphase spreads. Ideally the laboratories were asked to provide the material for both DNA analyses and the cytogenetic analysis from the same cultures of the cells. In a few cases this could not be done, for example, when a first sample did not meet quality control criteria and additional samples had to be prepared, but all samples were provided from as close a passage as possible. The full details of each cell line included in the study, the passage levels of each sample and culture details, including split ratios, culture time between passages, and medium and subculture methodology, are provided in Supplementary Table 1.

Karyology. Chromosome analysis was carried out in accord with the general principles developed by the International Stem Cell Banking Initiative ${ }^{65}$. Briefly, cells were to be cultured in the presence of $0.1 \mu \mathrm{g} / \mathrm{ml}$ colcemid (Invitrogen) for up to $4 \mathrm{~h}$, followed by dissociation with $0.25 \%$ trypsin/versene (Invitrogen). The cells were pelleted by centrifugation and resuspended in prewarmed $0.0375 \mathrm{M} \mathrm{KCl}$ hypotonic solution and incubated for $10 \mathrm{~min}$. After centrifugation the cells were resuspended in fixative (3:1 methanol/acetic acid) and sent to the central karyotyping facility, where metaphase spreads were prepared on glass microscope slides and G-banded by brief exposure to trypsin and stained with 4:1 Gurr's/Leishmann's stain (Sigma-Aldrich). (See Supplementary Note 2 for detailed protocols.) A minimum of 10 metaphase spreads were analyzed in detail and a further 20 counted and scored from both the early- and late-passage cultures. A 30-cell examination can exclude mosaicism at the $10 \%$ level with $95 \%$ confidence ${ }^{66}$. Analysis was performed by a Health Professionals Council registered Clinical Cytogeneticist in a CPA accredited laboratory (Duncan Baker DipRCPath, Sheffield Diagnostic Genetic Services, Sheffield Children's NHS Foundation Trust and the CSCB, University of Sheffield). A representative image of each cell line was captured using Applied Imaging's Cytovision system. All abnormal karyotype results were confirmed by two other experienced analysts (Tamar Golan-Lev, Hebrew University, Jerusalem, and Karen Montgomery, WiCell).

Cell lines were described as abnormal if at least two cells were found with the same chromosome aberration. Fluorescent in situ hybridization (FISH) was used to characterize abnormalities when appropriate. Abnormalities confined to a single cell were recorded (Supplementary Table 2). For those in which the single cell abnormality involved chromosomes 1, 12, 17 or 20, interphase FISH analysis with appropriate probes (Supplementary Table 2) was performed to confirm or exclude low level mosaicism. FISH analysis was also performed, on the early-passage cultures of those cell lines with normal early cultures and abnormal late cultures to confirm or exclude low-level mosaicism in the early passage.

SNP array analysis. To analyze genomic structural variations below the resolution of standard chromosomal banding analysis, we chose the Illumina $1 \mathrm{M}$ Quad SNP array technology. In addition to providing the ability to detect structural variants by virtue of appropriately spaced invariant genetic features, the SNP features allowed characterization of the population structure between all human ES cell lines analyzed. The samples received were run on the Illumina $1 \mathrm{M}$ Quad platform and the data were subjected to structural variant quality control (QC) assessment in which the minimum number SNP/structural variant $=10$, the minimum length of structural variant $=1 \mathrm{~kb}$, the minimum confidence score for structural variant call $=10$, the Log R Ratio s.d. $<0.35$, the B allele freq s.d. $<0.06$ and the waviness factor $-0.04<\mathrm{WF}<0.04$.

PLINK ${ }^{67}$ was used to detect genetically related samples (early- and latepassage paired samples and other sibling relationships) and the related samples with the lower call-rate were removed. QC was performed on these samples, by excluding structural variant probes, nonautosomal SNPs, and samples and SNPs with call-rates $<95 \%$. Thereafter, 982,351 SNPs from 114 unrelated samples were merged with three publicly available data sets: HGDP, Hapmap Phase 2 (release 23) and the Pan-Asian SNP Initiative (PASNPI). Additional QC was then performed on the merged data set by exclusion of samples and SNPs with call-rates $<95 \%$ and monomorphic SNPs. Furthermore, we excluded the extremely diverse southeast-Asian samples in PASNPI, to focus the analyses on human ES cell origins in Africa, Europe, Central-south Asia and East Asia. Ultimately, the merged data set contained 1,967 samples and 11,279 SNPs. Subsequently, a series of PC analyses (PCAs) were performed. The PCAs were performed using smartpca from the software EIGENSTRAT ${ }^{68}$ (found in EIGENSOFT, http://genepath.med.harvard.edu/ reich/Software.htm).

The first PCA was performed on the entire final merged data set. The scatter plot of PC2 against PC1 of this PCA was then dissected into four sectors, based primarily on the global regions of Africa (PC2 <-0.04), Middle EastEurope-Central-South Asia (PC1 $>0.005$ and PC2 $>0.008)$, Oceania-AmericaCentral-South Asia $(-0.015<\mathrm{PC} 1<0.005)$ and East Asia $(\mathrm{PC} 1<-0.015)$. (Fig. 1a). PCAs were then reperformed on the samples found in these four sectors. Notably, most of the human ES cell samples were concentrated in the European sector (with the HGDP-Europe and HapMap European cluster).

Hence, to further elucidate the origins of the human ES cell lines in Europe, we removed 16 human ES cell European outliers in the Central-south AsiaEurope-Middle East sector (Fig. 1d); these are considered to be of dubious ancestry, suspected to originate from two groups: Central-south Asian or Southern European or mixed from both; Middle Eastern or Eastern European or mixed from both. Lack of reference populations and insufficient SNPs could be possible reasons for this uncertainty in determination of ancestry. The remaining human ES cell samples (found in the European cluster) were then merged with 1,385 samples and 168,352 SNPs from the POPRES European data set ${ }^{45}$. (The sample and SNP lists were obtained through correspondence with the author.) This second merged data set between human ES cell and POPRES European data yielded 1,448 samples and 55,972 SNPs, after excluding samples and SNPs with call rates $<95 \%$ and monomorphic SNPs. PCA was then performed again on this data set (Fig. 1b). Color coding was deliberately implemented in a similar manner to that of reference ${ }^{45}$.

The human ES cell lines were classified into broad categories of European, Asian, African and other ancestries and then further subclassified into ethnicities listed in Table 1. Human ES cell samples that are full siblings of the 114 samples were included, resulting in a total of 120 human ES cell lines.

Frequency and mapping analysis of SNP data. The PennCNV ${ }^{47}$ HiddenMarkov model algorithm was used to identify structural variants in the ISCI samples with human hg18 as the reference genome. High-quality structural variant calls were filtered as follows: first, samples were checked for overall quality using the following criteria from the PennCNV output: $0.01<\mathrm{BAF}_{-}$ drift $<0.01 ;-0.05<\mathrm{WF}<0.05$; LRR_SD $<0.35$. Second, individual structural variant calls for samples passing QC were assessed as follows: minimum SNPs per structural variant $>10$; structural variant Length $>1 \mathrm{~K}$; PennCNV confidence threshold $>10$. Most samples that failed quality control either exhibited extensive karyotypic abnormalities and/or bad SNP call rates, both of which could contribute to difficulties in structural variant detection. The samples that did pass quality control identified 39,926 deletions of an average size of $23.1 \mathrm{~kb}$ and 14,351 duplications of an average size of $117.4 \mathrm{~kb}$ in length. These size and total number differences between deletions and duplications is consistent with previous structural variant studies of human populations ${ }^{47}$. The sensitivity of detection was in the $5-10 \%$ range based on CNV calls in regions identified as amplified by karyotype analysis.

DNA methylation analysis. $1 \mu \mathrm{g}$ of genomic DNA was treated with sodium bisulfite using the Zymo EZ-96 DNA Methylation Kit (Zymo Research) following the manufacturer's recommended protocol. DNA methylation measurements were generated using the Illumina GoldenGate DNA methylation platform as previously described ${ }^{69}$, at the University of Southern California Epigenome Center production facility. The sequences assayed were previously identified ${ }^{53}$ as targets of SUZ12, a subunit of the Polycomb Repressive Complex 2, in the nonrepetitive portion of the genome in human 
ES cells (Supplementary Table 4 array loci, sequences, etc). DNA methylation measurements ( $\beta$-values) were generated for 1,452 autosome and 84 $\mathrm{X}$-linked loci.

To obtain a global view of the DNA methylation changes undergone by each cell line pair from the early to the late passage, CDF curves were generated. CDF curves were chosen because they are able to concomitantly capture and visually represent the changes detected in all loci analyzed in a single line. To test whether increased passage number correlated with increase in the number of loci gaining DNA methylation, we calculated the difference in passage number between the early and the late member of each cell line pair, ranked these differences and divided the samples into quartiles based on passage-number difference. To investigate whether sibling lines behaved similarly in terms of DNA methylation changes, we calculated the number of loci with an absolute DNA methylation difference $\geq 10 \%$ between the early and late member of each pair of sibling lines. We then compared whether the total number of loci with the specified absolute change in DNA methylation differed significantly from the number of loci undergoing a similar change in pairs of unrelated lines using a Wilcoxon signed-rank test. The data were analyzed using the R statistical programming package version 2.12 .1 (http:// www.r-project.org/).

Cell line availability. Supplementary Table 5 provides contact information and conditions of availability for the cell lines described in this study.

65. The International Stem Cell Banking Initiative. Consensus guidance for banking and supply of human embryonic stem cell lines for research purposes. Stem Cell Rev. 5, 301-314 (2009).

66. Hook, E.B. Exclusion of chromosomal mosaicism: tables of $90 \%, 95 \%$ and $99 \%$ confidence limits and comments on use. Am. J. Hum. Genet. 29, 94-97 (1977).

67. Purcell, S. et al. PLINK: a tool set for whole-genome association and populationbased linkage analyses. Am. J. Hum. Genet. 81, 559-575 (2007).

68. Price, A.L. et al. Principal components analysis corrects for stratification in genomewide association studies. Nat. Genet. 38, 904-909 (2006).

69. Bibikova, M. et al. High-throughput DNA methylation profiling using universal bead arrays. Genome Res. 16, 383-393 (2006). 
Anexo 5: Artigo de revisão publicado na revista Stem Cell Reviews \& Reports em março de 2011. 


\title{
A Survey of Parameters Involved in the Establishment of New Lines of Human Embryonic Stem Cells
}

\author{
Ana Maria Fraga • Érica Sara Souza de Araújo • \\ Raquel Stabellini • Naja Vergani • Lygia V. Pereira
}

Published online: 18 March 2011

(C) Springer Science+Business Media, LLC 2011

\begin{abstract}
Since the derivation of the first human embryonic stem cell (hESC) lines by Thomson and coworkers in 1998, more than 1,200 different hESC lines have been established worldwide. Nevertheless, there is still a recognized interest in the establishment of new lines of hESC, particularly from HLA types and ethnic groups currently underrepresented among the available lines. The methodology of hESC derivation has evolved significantly since 1998, when human LIF (hLIF) was used for maintenance of pluripotency. However, there are a number of different strategies for the several steps involved in establishing a new line of hESC. Here we make a survey of the most relevant parameters used between 1998 and 2010 for the derivation of the $375 \mathrm{hESC}$ lines deposited in two international stem cell registries, and able to form teratomas in immunocompromised mice. Although we identify some trends in the methodology for establishing hESC lines, our
\end{abstract}

Ana Maria Fraga, Érica Sara Souza de Araújo, Raquel Stabellini and Naja Vergani contributed equally to this work.

Electronic supplementary material The online version of this article (doi:10.1007/s12015-011-9250-x) contains supplementary material, which is available to authorized users.

A. M. Fraga •É. S. Souza de Araújo · R. Stabellini - N. Vergani •

L. V. Pereira $(\bowtie)$

Laboratório Nacional de Células-Tronco Embrionárias and Instituto Nacional de Ciência e Tecnologia em Células-Tronco e Terapia Celular, Departamento de Genética e Biologia Evolutiva, Instituto de Biociências, Universidade de São Paulo,

São Paulo, SP 05508-090, Brazil

e-mail: lpereira@usp.br

Present Address:

R. Stabellini

Programa de Transtorno Bipolar (PROMAN), Instituto de Psiquiatria, Universidade de São Paulo, São Paulo, Brasil data reveal a much greater heterogeneity of strategies than what is used for derivation of murine ESC lines, indicating that optimum conditions have not been consolidated yet, and thus, hESC establishment is still an evolving field of research.

Keywords Human embryonic stem cells · Cell line derivation · Pluripotency $\cdot$ Human embryo $\cdot$ Cell therapy

\section{Introduction}

Pluripotent embryonic stem cells (ESC) were first derived from the inner cell mass (ICM) of mouse blastocysts in 1981 [1]. They are defined by unlimited self-renewal and the ability to differentiate - both in vitro and in vivo - into cell types of endodermal, mesodermal and ectodermal origins, rendering them a promising applicability in cell replacement therapies [2]. These characteristics also make ESCs a powerful tool for studying the molecular mechanisms underlying cellular differentiation, as well as for accessing the biological effects of pharmaceutical compounds on the normal embryo development (reviewed by [3]).

Despite continuous efforts from many laboratories, it was only in 1998 that the first lines of humans ESC (hESC) were described [4]. After that, many other groups reported on the derivation of hESCs, and the number of different lines registered on the available databases rapidly increased.

However, there is a growing evidence of the heterogeneous behavior of the distinct lines of hESC regarding their differentiation potential [5] and their epigenetic stability [6]. Moreover, if they are intended to be used as sources of tissues for transplants, there may be a need for HLA matching between the hESCs and patients, and thus the establishment of a large number of HLA-diverse hESC lines is required [7, 8]. Still regarding their clinical use, 
there is also a need to optimize xeno-free and fully defined systems in order to avoid potential contaminants. Therefore, there is a continuous interest in establishing new lines of $\mathrm{hESC}$ to address these issues.

The conditions described for the establishment of the first human ESC lines $[4,9]$ were essentially the same as those used for the derivation of mouse ESCs [1]. Since then, novel signaling pathways controlling pluripotency of hESCs have been identified and, together with the development of new reagents, they have led to the improvement of strategies for deriving new hESC lines [10]. Here we make a survey of the different protocols used in the last 12 years for the establishment of hESC lines from two international stem cell registries, looking for trends in the several steps involved in the process. Our results show that, although there were significant advances in methodology and reagents, there is still a great heterogeneity in the strategies employed for hESC derivation, indicating that optimal conditions have not been consolidated yet, and thus, this is still an intensively evolving field of research.

\section{Gathering Information From Human Embryonic Stem Cell Registries}

Data were obtained from the European Human Embryonic Stem Cell Registry (www.hescreg.eu) and the University of Massachusetts' International Stem Cell Registry (www. umassmed.edu/iscr) as of December 7th, 2010. Only those lines of hESC with pluripotency demonstrated by the capacity to form teratomas when injected into immunodeficient mice were included in the analysis.

The following parameters were analyzed: embryo - source (generated for reproduction or research), fresh or frozen, stage of development, quality, method of ICM isolation; culture conditions - basic medium, protein source, factors for maintenance of pluripotency, type of support, efficiency of derivation. Specific details regarding different aspects of the derivation process were obtained also from the corresponding publication, when available. Whenever data from the registry differed from those in the referenced publication, we considered the data described in the latter, with the exception of derivation date, which was taken from the registries. In addition, whenever derivation data differed among different publications from the same group, we considered the information that was first published.

\section{Derivation of hESCs Around the World-When, Where and How}

As of December 7th, 2010, 1,291 different hESC lines were registered in the two stem cell registries (hESCReg and
UMass ISCR). Of those, 375 lines were reported to be able to form teratomas when injected into immunodeficient mice. We listed the different parameters involved in the derivation of these 375 lines, extracting the exact data from the registries or from the corresponding publication, when available (Supplementary Table 1). Twenty six hESC lines lacked information regarding the year of derivation and were therefore excluded from the analysis of the evolution of the methodologies throughout time.

Figure 1 shows the number of new hESC lines established per year. It is interesting to note that it took 2 to 4 years since the first derivations by Thomson et al. (1998) and by Reubinoff et al. (2000) for other groups to establish new lines of hESC. The composition of the derivation medium described in those two first articles contained hLIF and MEFs as factors for maintenance of pluripotency. It was only in 2000 that the use of bFGF was described as a requirement for the prolonged culture of hESC in serum-free medium [11]. From then on, bFGF has been consolidated as the major growth factor for maintenance of hESCs' pluripotency, and this may have had a role in the raise of the number of derivations observed thereafter.

The number of new hESC lines greatly increased from 2004 to the end of 2010, as well as the number of research groups and laboratories engaged in their establishment. In fact, there was a first peak of generation of new hESC lines in 2004, contributed mostly from one group in the USA [12], one in Korea [13] and two in Sweden [14, 15], which accounted for 16, 9 and 10 of the total of 38 new cell lines derived that year, respectively (Fig. 1).

The derivations of the majority $(88.8 \%)$ of those hESC lines were described in peer-reviewed journals, even in the last 2 years (Fig. 1). However, most of the latest articles tend to report only optimizations of the derivation protocols (e.g. $[16,17])$ or hESC lines established from alternative

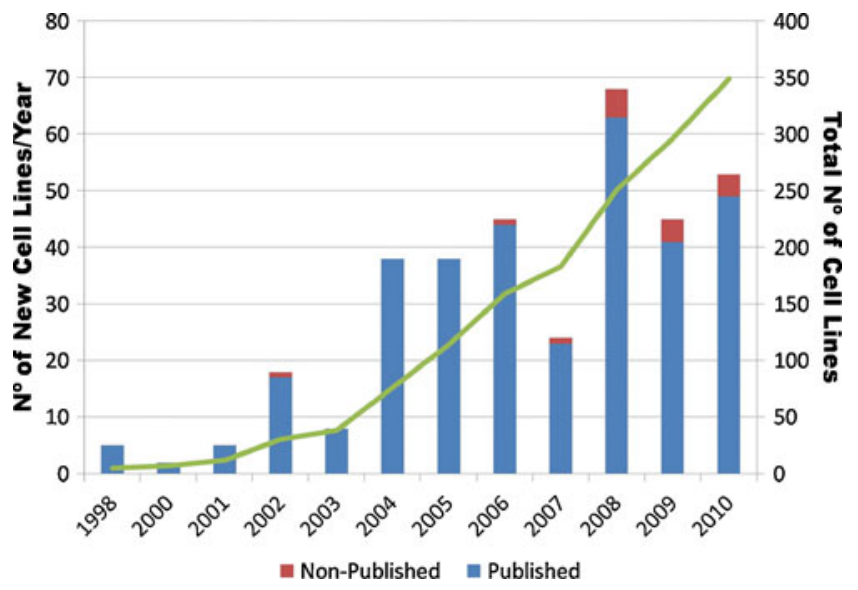

Fig. 1 Distribution of new hESC lines derived per year (blue/red barsleft vertical axis), and total number of hESC lines in the period (green line-right vertical axis) 
sources of embryo, for example from poor quality embryos or morulae [18-20]. In addition, in the most recent papers, the report on the derivation of the new hESC lines usually accounted for a small part of these publications, where the cell line served as the basis for the development of the main scientific study, indicating less availability for publishing new derivations without any novel scientific aspect. One recent exception was a special issue of In Vitro Cellular \& Developmental Biology_Animal, dedicated to report new derivations of hESC lines [21]. In this single issue, 25 articles described the establishment of 45 new lines. Nevertheless, given the interest of increasing the diversity of available hESC lines, it is important to have a venue for publicizing the new lines and their specific characteristics, a role well performed by human stem cell registries [22].

\section{Source of the Embryo}

Overall, the vast majority ( $98.4 \%$ of the informative lines) of embryos used for the derivation of hESC lines were surplus from reproductive cycles, whereas only $1.6 \%$ of the lines were derived from embryos generated specifically for research (Fig. 2a). Out of the six lines derived specifically for research, four were derived in China and two in Belgium (Supplementary Table 1), countries with permissive

a

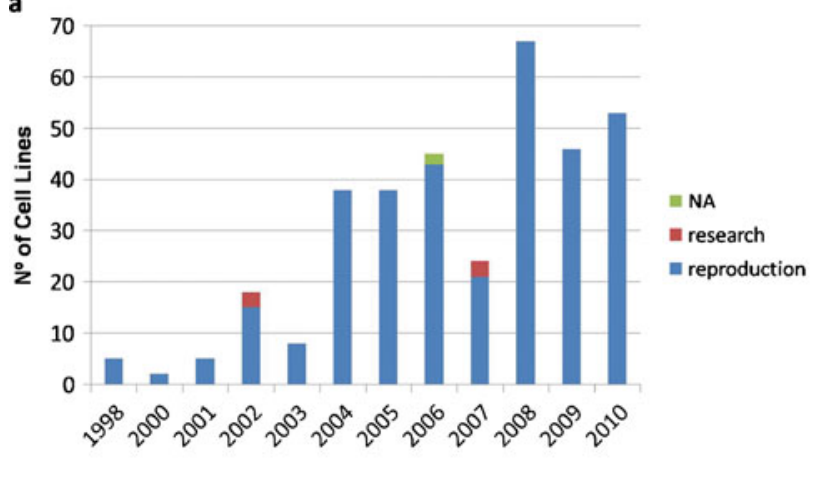

c

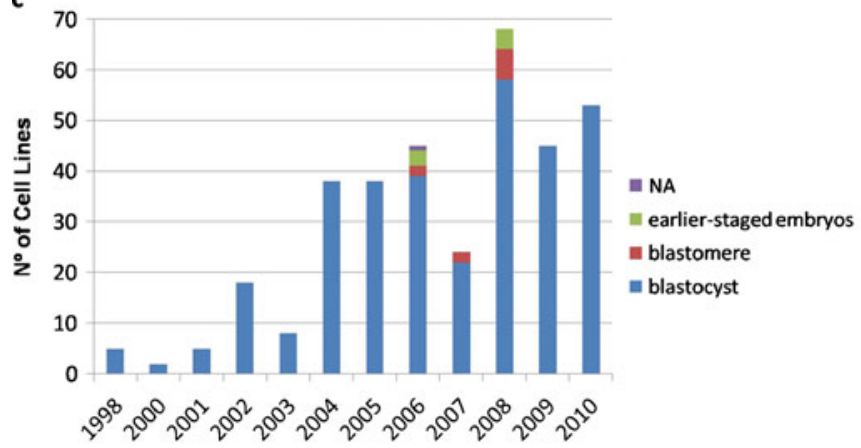

Fig. 2 Embryos used for establishment of hESC lines. Number of cell lines per year derived from a embryos generated for reproductive and research purposes; b fresh and frozen embryos; c stage of development of the embryos used for derivation of the hESC lines; $\mathbf{d}$ method legislations concerning stem cell research and somatic cell nuclear transfer for therapeutic purposes [23]. In addition, in the last 3 years none of the hESC lines analyzed were derived from embryos generated for research. Although other countries, like USA and England, also permit the generation of human embryos for research, no hESC lines registered have been derived from this type of embryo in these countries. Therefore, these data show that creating embryos exclusively to generate hESC lines is not a common practice, probably due, at least in part, to the difficulties in obtaining donors of human oocytes.

One implication of the use of surplus embryos for the derivation of new hESC lines is the possible limited genetic diversity of these embryos, which will come mostly from private clinics of assisted reproduction that may not attend to the whole ethnic admixture of a given population [24]. In fact, recent articles have described a restricted genetic background of the hESC lines established worldwide, which are mainly of European and East-Asian ethnicity [25-27]. Thus, it will be important to develop strategies to obtain ethnically diverse embryos for the derivation of new hESC lines with distinct genetic backgrounds and different HLA types.

Frozen (144 lines) and fresh (111 lines) embryos have been equally used for derivations (Fig. 2b). The use of

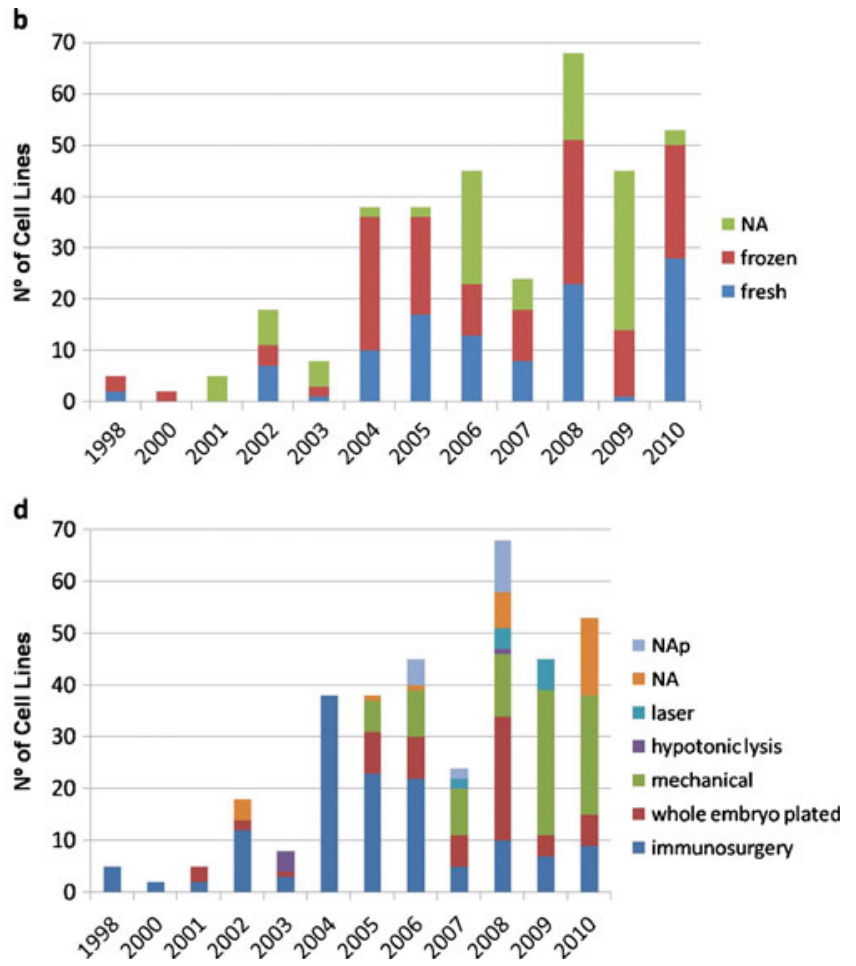

employed for isolation of pluripotent cells. $N A$ information not available. $N A p$ do not apply (lines derived from blastomeres or early-staged embryos (6-cell up to morula staged embryos)) 
frozen embryos allows working with larger batches of embryos at once, whereas fresh embryos, if supernumerary from reproduction cycles, tend to be available in smaller numbers and at shorter notice for each experiment. Nevertheless, some researchers reported better efficiencies of hESC line derivation with fresh rather than frozen embryos (reviewed by [28]). In our survey, we could not identify this difference from the available data.

\section{Quality of the Embryo}

From the 375 cell lines listed in this review, 216 (57.6\%) were informative regarding the quality of the embryo from which they were derived. However, since different methodologies for embryo scoring were employed by the different laboratories, we used in our analysis the classification provided either on the European hESC database or in the published articles, where the quality of the embryos was defined simply as "good", "intermediate" or "poor". For some of the cell lines, we adjusted the information provided by the authors for the classification format mentioned above (see Supplementary Table 1). From the 142 cell lines that met this classification, $69(48.6 \%)$ were originated from embryos that had been classified as "good", 21 $(14.8 \%)$ as "intermediate", and $52(36.6 \%)$ as "poor". Thus, although the majority of the lines were derived from good quality embryos, a high proportion of lines were established from poor embryos, not usually suitable for reproduction. Nevertheless, the availability of more information on the quality of the embryo used to derive each cell line, as well as the use of a single common method for grading embryo quality, would be fundamental in accessing the role of this parameter in the feasibility of generating a hESC line.

\section{Developmental Stage of the Embryo}

The great majority (95.1\% of the informative lines) of the $\mathrm{hESC}$ lines with potential to form teratoma were originated from isolated ICMs or from whole plated embryos at the blastocyst stage, whereas only $2.2 \%$ were established from earlier-staged embryos (6-cell up to morula staged embryos), and 2.7\% from single blastomeres (Fig. 2c and Supplementary Table 1). In fact, four independent groups (in the UK, USA, Spain and Australia) have reported on the derivation of hESC lines from earlier-staged embryos, and four groups have described the generation of hESC lines from isolated single blastomeres (in the USA, Switzerland, Belgium, Spain- $[29,30])$, demonstrating the feasibility of these strategies, which would increase the number of available embryos adequate for hESC derivation. However, it is worth noting that the main goal for the derivation of $\mathrm{hESC}$ lines from single blastomeres is generally to avoid the controversies involved in the destruction of human embryos, rather than to obtain a better source of cells for hESC derivation.

\section{Strategies of ICM Isolation}

Differently from the method generally used for the establishment of murine ES cells-where the whole embryo is plated and cells from the inner cell mass are mechanically isolated from the surrounding trophectoderm within few days -, the procedure adopted until 2004 for the derivation of hESC lines included the isolation of the ICM from the embryo before plating (Fig. 2d). Clearly, the less an embryo is manipulated, the smaller the chance of causing any damage to its cells. However, as trophectoderm cells proliferate very fast, they can suppress the growth of the ICM, and even generate a trophectoderm stem cell line [14].

The technique mostly employed until 2004 for the isolation of human ICM was immunosurgery, a nonspecific process based on the embryo susceptibility to complement-dependent antibody cytotoxicity [31]. However, when the trophectoderm is not intact, immunosurgery may damage cells from the ICM [32], decreasing the chances of those cells to yield a new hESC line. In addition, this approach involves the use of animalderived components which may not be adequate for some applications of the hESC lines. Therefore, from 2005 on, an increasing number of groups have been using alternative methods, namely mechanical or laserassisted isolation of the ICM (Fig. 2d), although the latter is less widely adopted probably due to the limited availability of the laser equipment. Finally, lines of hESC have been established from whole plated embryos, mostly when embryo quality is poor hampering isolation of the ICM. Nevertheless, this strategy was also employed with $10.6 \%$ of the good quality embryos, indicating a lack of requirement for ICM isolation.

Human blastocysts are not usually abundantly available, and thus researchers have been trying to bypass the need of high-quality blastocysts for hESC derivation. Since the first report of hESC lines derived from blastomeres in 2004 [29, 30], there has been an increase in the use of alternative sources of pluripotent cells (e.g., morulae or single blastomeres) and also of poor quality embryos, usually not employed for reproduction. These developments may be related to the growing number of hESC lines that have been established without ICM isolation between 2006 and 2008 .

Besides a trend not to employ immunosurgery, there is a tendency to use mechanical dissection of the ICM, but the best methodology to isolate ICM from human embryos has not yet been consolidated. Thus, the morphology and 
quality of the embryo play important roles in the choice of the method for ICM isolation. Nevertheless, since many lines have been established from whole plated embryos, the main novelty in the last 12 years has been the lack of requirement for isolation of ICM for hESC derivation, simplifying the procedure.

\section{Culture Media}

Four main components are generally used during the derivation and maintenance in culture of a hESC line: the basic medium (e.g. DMEM, DMEM-F12, KO-DMEM), the protein source (e.g. FBS, KSR), the factor(s) used to stimulate self-renewal (e.g. bFGF, LIF, insulin, different small molecules, and others), and the matrix/cell support (e.g. MEF, STO, HFF, Matrigel, and others). Tens of different combinations of the various types of these four components have been shown to be adequate for maintenance of the hESC lines in culture [33], and our analysis shows that many of them are also suitable for the derivation of new cell lines (Fig. 3).

Regarding the basal culture medium and protein source, KO-DMEM and KSR have been the most used reagents for the derivation of hESC lines since 2003 (Fig. 3a, b). In fact, 59.9\% (212 of 354 of informative
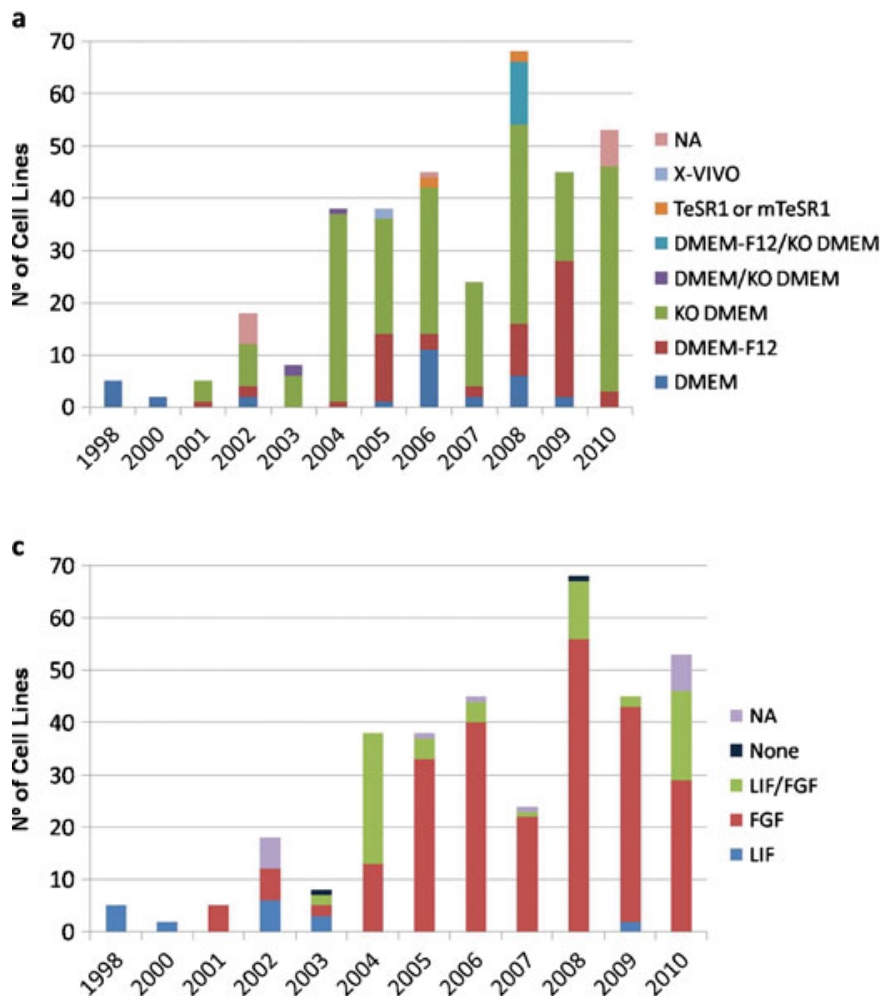

Fig. 3 Media composition. Human embryonic stem cell lines derived each year showing a basal medium; b protein supplement- $R H P$ recombinant human protein, $H S$ human serum, KSR knockout serum replacement, FBS fetal calf serum or fetal bovine serum, $N A p$ do not lines) of all the hESC considered in this review were cultured in these two components at least during some stage of the derivation (Supplementary Table 1). Thus, it comprises the most employed medium basis not only during the maintenance of the hESC lines in culture [33] but also during their derivation.

KO-DMEM is a "DMEM-based" medium with osmolarity reduced in order to improve the growth of the undifferentiated ESC, while the KSR, developed in 1998, is more suitable for culturing ESC than the regular fetal bovine serum because it does not contain undefined growth or differentiation promoting factors [34]. In agreement to this, FBS has been shown to promote differentiation of the ESC at a higher rate [35]. Furthermore, although containing animal-derived components, KSR is a defined supplement, avoiding the lot-to-lot composition variation found in FBS [36]. Nevertheless, even in the last 2 years, a significant number of hESC lines (21 lines out of 91 informative lines-23.1\%) were still established in a combination of KSR/FBS, which apparently improves the initial outgrowth of the ICM, and then are subsequently transitioned into KSR alone for long term culture [17] (Fig. 3b and Supplementary Table 1).

The use of animal-derived components in hESC cultures has became a major concern after the discovery, in 2005, of
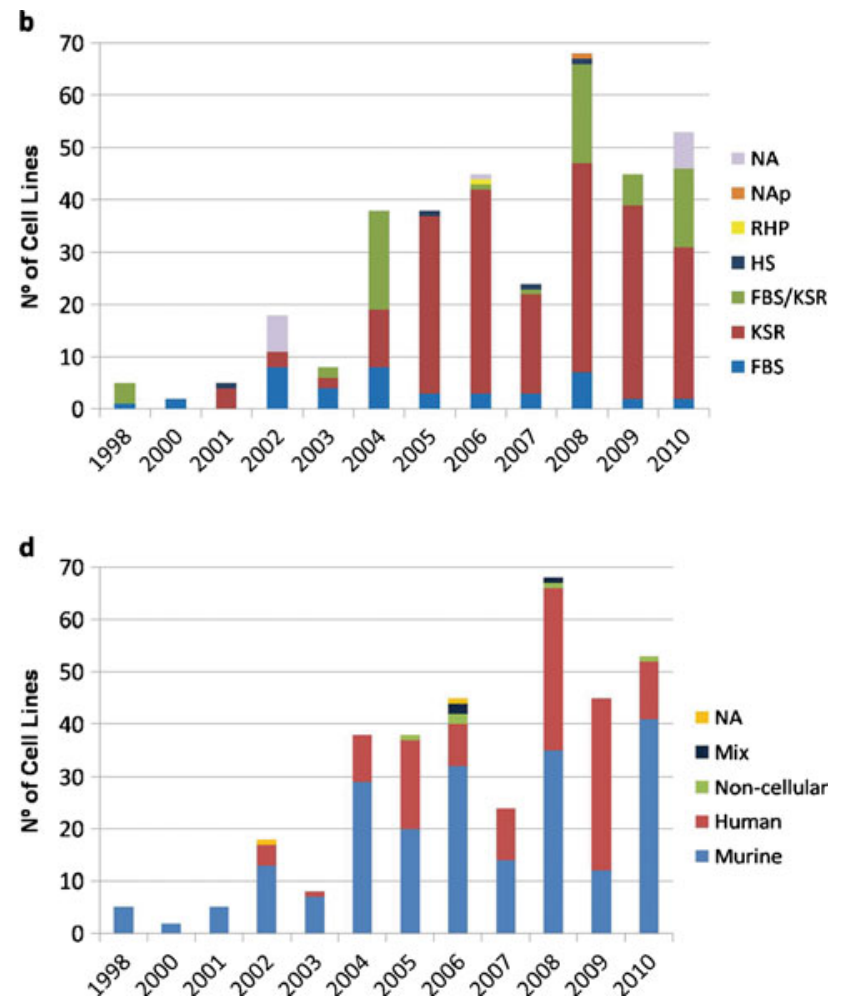

apply (lines derived in complete medium); $\mathbf{c}$ factor for maintenance of pluripotency; d Type of cell support. Mix different combinations of support; $N A$ information not available 
potentially immunogenic nonhuman sialic acid, Neu5Gc, on hESC lines cultured on animal cells or in animal serum products [37] Although this is not a limitation for lines established for research purposes, different groups, interested in deriving hESC lines for therapy, have been working on alternative animal-free conditions, using xenofree media including the use of TeSR 1 and X-VIVO, and recombinant human proteins as serum substitutes.

Maintenance of pluripotency of murine ES cells is achieved by culturing them on mitotically inactivated mouse embryonic fibroblasts (MEF) - feeder layers, and in the presence of LIF. Although hLIF was used in the establishment of the first lines of hESCs [4, 9], it has been shown that it is not capable of promoting long term maintenance of these cells in an undifferentiated state [38]. From 2002 on, bFGF, either alone or in combination with hLIF, has been consolidated as the major factor for the maintenance of pluripotency of hESC during derivation and long term culture [33] (Fig. 3c).

Similar to murine ES cells, the first hESC lines were established in MEFs. However, in order to avoid using xeno-components, since 2003 the use of different types of alternative human support cells and acellular matrices for the establishment of hESCs is observed (Fig. 3d). In spite of that, a significant number of cell lines continue to be derived in the presence of MEFs, indicating that support cells have a greater capacity of maintaining pluripotency of hESCs, and/or their availability and cost are more advantageous than the other alternatives.

We listed other parameters of the methodology for hESC derivation, including time of first passage, method of passage (enzymatic versus mechanical), frequency of media change, and efficiency of derivation (Supplementary Table 1). However, these parameters varied widely among cell lines, hampering their analysis, which was not conclusive. One important information would be the efficiency of the different protocols, regarding the number of cell lines obtained using that particular methodology per embryo manipulated. Nevertheless, this data was not readily available in several publications, and therefore could not be evaluated in this survey.

\section{Conclusions}

When starting a project involving the derivation of new lines of hESC, how to choose the best strategy? This will depend primarily on the quality of the available embryos, and on the use one wants to make of the lines. If they are meant exclusively for research, there may be no concerns about the use of animal-derived products. In contrast, if the new lines are to be used for therapy, although not a requirement, defined and animal-free conditions are more adequate. Nevertheless, it is important to note that hESC lines established in the presence of xeno-components can be transitioned into culture conditions adequate for clinical use, as it is the case of the very first hESC line established, $\mathrm{H} 1$, differentiated into oligodendrocytes for the treatment of spinal cord injury (www.geron.com).

Due to the lack of homogeneity on data presented for hESCs derivation, meta-analysis and reviews like our own are hampered. One of the most striking difficulties we have found concerns the definition of embryo quality, as researchers use different embryo classification systems, and there is little information available on the proportion of embryos of different quality used to derive each line. Another issue refers to the efficiency of derivation: when available, which is not the rule, rates are based on the number of hESCs versus either the initial number of embryos or, alternatively, the number of embryos that reached blastocyst stage, thus being heterogeneous. Although scientific advisory boards define and monitor eligibility criteria for the listing of hESCs in the registries, there is an urge to standardize the information deposited.

In summary, our data shows a great heterogeneity in the methodologies for hESC derivation, indicating that the optimum conditions have not been consolidated yet. Nevertheless, the strategies have significantly evolved since 1998: MEFs are still the most used support cells, but KODMEM/KSR with bFGF has been recognized as a more adequate culture medium. In addition, the initial requirement for isolation of ICM is not observed anymore, and lines can be established also from whole plated and low quality embryos. Finally, the concern about the emergence of commerce of embryos created for research purposes [39] has not materialized, since the vast majority of the available lines were established from embryos generated for reproductive purposes. However, it is important to notice that all the listed methodologies yield lines of hESC that still differ significantly from the murine counterpart in morphology and epigenetic stability, among other characteristics [40]. More recent findings on the effects of physiological levels of oxygen on the epigenetic stability of hESC [41], and on the role of kinase inhibitors and hLIF in the maintenance of human induced pluripotent stem cell (hiPSC) in a mouse ESC (mESC)-like state [40], promise to revolutionize the field. Human ESCs may never be as homogeneous as mESCs, after all, humans are outbred. Nevertheless, for the next years we expect important improvements in the conditions for establishing and culturing new lines of hESC more amenable for research and therapy than the currently available ones.

Acknowledgements This work was supported by a grant from Conselho Nacional de Desenvolvimento Científico e Tecnológico/ Departamento de Ciência e Tecnologia do Ministério da Saúde (CNPq/MS/DECIT). AMF, RS and ESSA have/had Ph.D. fellowships from Fundação de Amparo à Pesquisa do Estado de São Paulo (FAPESP). The authors declare no conflicts of interest. 


\section{References}

1. Evans, M. J., \& Kaufman, M. H. (1981). Establishment in culture of pluripotential cells from mouse embryos. Nature, 292, 154-156.

2. Guasch, G., \& Fuchs, E. (2005). Mice in the world of stem cell biology. Nature Genetics, 37(11), 1201-1206.

3. Pera, M. F., \& Trounson, A. O. (2004). Human embryonic stem cells: prospects for development. Development, 131(22), 5515-5525.

4. Thomson, J. A., Itskovitz-Eldor, J., Shapiro, S. S., et al. (1998). Embryonic stem cell lines derived from human blastocysts. Science, 282, 1145-1147.

5. Osafune, K., Caron, L., Borowiak, M., et al. (2008). Marked differences in differentiation propensity among human embryonic stem cell lines. Nature Biotechnology, 26(3), 313-315.

6. Silva, S. S., Rowntree, R. K., Mekhoubad, S., \& Lee, J. T. (2008). $\mathrm{X}$-chromosome inactivation and epigenetic fluidity in human embryonic stem cells. Proceedings of the National Academy of Science (USA), 105(12), 4820-4825.

7. Drukker, M., \& Benvenisty, N. (2004). The immunogenicity of human embryonic stem-derived cells. Trends in Biotechnology, 22, 136-141.

8. Nakajima, F., Tokunaga, K., \& Nakatsuji, N. (2007). Human leukocyte antigen matching estimations in a hypothetical bank of human embryonic stem cell lines in the Japanese population for use in cell transplantation therapy. Stem Cells, 25, 983-985.

9. Reubinoff, B. E., Pera, M. F., Fong, C. Y., Trounson, A., \& Bongso, A. (2000). Embryonic stem cell lines from human blastocysts: somatic differentiation in vitro. Nature Biotechnology, 18(4), 399-404.

10. Hasegawa, K., Pomeroy, J. E., \& Pera, M. F. (2010). Current technology for the derivation of pluripotent stem cell lines from human embryos. Cell Stem Cell, 6(6), 521-531.

11. Amit, M., Carpenter, M. K., Inokuma, M. S., et al. (2000). Clonally derived human embryonic stem cell lines maintain pluripotency and proliferative potential for prolonged periods of culture. Developmental Biology, 227(2), 271-278.

12. Cowan, C. A., Klimanskaya, I., McMahon, J., et al. (2004). Derivation of embryonic stem-cell lines from human blastocysts. The New England Journal of Medice, 350, 1353-1356.

13. Park, S. P., Lee, Y. J., Lee, K. S., et al. (2004). Establishment of human embryonic stem cell lines from frozen-thawed blastocysts using STO cell feeder layers. Human Reproduction, 19, 676-684.

14. Inzunza, J., Gertow, K., Strömberg, M. A., et al. (2005). Derivation of human embryonic stem cell lines in serum replacement medium using postnatal human fibroblasts as feeder cells. Stem Cells, 23(4), 544-549.

15. Darnfors, C., Flodin, A., Andersson, K., et al. (2005). Highresolution analysis of the subtelomeric regions of human embryonic stem cells. Stem Cells, 23(4), 483-488.

16. Chavez, S. L., Meneses, J. J., Nguyen, H. N., Kim, S. K., \& Pera, R. A. (2008). Characterization of six new human embryonic stem cell lines (HSF7, 8, -9, -10, -12, and -13) derived under minimal-animal component conditions. Stem Cells and Development, 17(3), 535-546.

17. Chen, A. E., Egli, D., Niakan, K., et al. (2009). Optimal timing of inner cell mass isolation increases the efficiency of human embryonic stem cell derivation and allows generation of sibling cell lines. Cell Stem Cell, 4(2), 103-106.

18. Chung, Y., Klimanskaya, I., Becker, S., et al. (2008). Human embryonic stem cell lines generated without embryo destruction. Cell Stem Cell, 2(2), 113-117.

19. Lerou, P. H., Yabuuchi, A., Huo, H., et al. (2008). Human embryonic stem cell derivation from poor-quality embryos. Nature Biotechnology, 26(2), 212-214.

20. Liu, W., Yin, Y., Long, X., et al. (2009). Derivation and characterization of human embryonic stem cell lines from poor quality embryos. Journal of Genetics and Genomics, 36, 229239.
21. Andrews, P. W., Stacey, G. N., \& Sato, J. D. (editors) (2010). Special issue on novel human embryonic stem cell lines and related resources. In Vitro Cellular \& Developmental Biology. Animal, 46(3-4), 167-402.

22. Borstlap, J., Luong, M. X., Rooke, H. M., et al. (2010). International stem cell registries. In Vitro Cellular \& Developmental Biology. Animal, 46, 242-246.

23. Pennings, G. (2003). New Belgian Law on Research on Human Embryos: trust in progress through medical science. Journal of Assisted Reproduction and Genetics, 20(8), 343-346.

24. Fraga, A. M., Sukoyan, M., Rajan, P., et al. (2010). Establishment of a Brazilian line of human embryonic stem cells in defined mediumimplications for cell therapy in an ethnically diverse population. Cell Transplantation, doi:10.3727/096368910X522261.

25. Snyder, E. Y., \& Loring, J. F. (2006). Beyond fraud-stem-cell research continues. The New England Journal of Medicine, 354 (4), 321-324.

26. Laurent, L. C., Nievergelt, C. M., Lynch, C., et al. (2010). Restricted ethnic diversity in human embryonic stem cell lines. Nature Methods, 7(1), 6-7.

27. Mosher, J. T., Pemberton, T. J., Harter, K., et al. (2010). Lack of population diversity in commonly used human embryonic stem-cell lines. The New England Journal of Medicine, 362(2), 183-185.

28. Greely, H. T. (2006). Moving human embryonic stem cells from legislature to lab: remaining legal and ethical questions. PLoS Medicine, 3(5), e143.

29. Klimanskaya, I., Chung, Y., Becker, S., Lu, S. J., \& Lanza, R. (2006). Human embryonic stem cell lines derived from single blastomeres. Nature, 444(7118), 481-485.

30. Feki, A., Bosman, A., Dubuisson, J. B., et al. (2008). Derivation of the first Swiss human embryonic stem cell line form a single blastomere of an arrested four-cell stage embryo. Swiss Medical Weekly, 138(37-38), 540-550.

31. Solter, D., \& Knowles, B. B. (1975). Immunosurgery of mouse blastocyst. Proceedings of the National Academy of Science (USA), 72, 5099-5102.

32. Schiewe, M. C., Hansen, C. T., \& Schmidt, P. M. (1992). Lack of antibody specificity by mouse trophectoderm during immunosurgery. Theriogenology, 38(1), 21-32.

33. Fernandes, A. M., Meletti, T., Guimarães, R., et al. (2010). Worldwide survey of published procedures to culture human embryonic stem cells. Cell Transplantion. doi:10.3727/ 096368909 X485067.

34. Horii, T., Nagao, Y., Tokunaga, T., \& Imai, H. (2003). Serum-free culture of murine primordial germ cells and embryonic germ cells. Theriogenology, 59(5-6), 1257-1264.

35. Khoo, M. L., McQuade, L. R., Smith, M. S., Lees, J. G., Sidhu, K. S., $\&$ Tuch, B. E. (2005). Growth and differentiation of embryoid bodies derived from human embryonic stem cells: effect of glucose and basic fibroblast growth factor. Biology of Reproduction, 73(6), 1147-1156.

36. Skottman, H., \& Hovatta, O. (2006). Culture conditions for human embryonic stem cells. Reproduction, 132, 691-698.

37. Martin, M. J., Muotri, A., Gage, F., \& Varki, A. (2005). Human embryonic stem cells express an immunogenic nonhuman sialic acid. Nature Medicine, 11, 228-232.

38. Dahéron, L., Opitz, S. L., Zaehres, H., et al. (2004). LIF/STAT3 signaling fails to maintain self-renewal of human embryonic stem cells. Stem Cells, 22(5), 770-778.

39. Winston, R. M. (2007). Does government regulation inhibit embryonic stem cell research and can it be effective? Cell Stem Cell, 1(1), 27-34.

40. Hanna, J., Cheng, A. W., Saha, K., et al. (2010). Human embryonic stem cells with biological and epigenetic characteristics similar to those of mouse ESCs. Proceedings of the National Academy of Science (USA), 107(20), 9222-9227.

41. Lengner, C. J., Gimelbrant, A. A., Erwin, J. A., et al. (2010). Derivation of pre-X inactivation human embryonic stem cells under physiological oxygen concentrations. Cell, 141(5), 872-883. 